\title{
Hydrogeology of the Schodack-Kinderhook Area, Rensselaer and Columbia Counties, New York
}

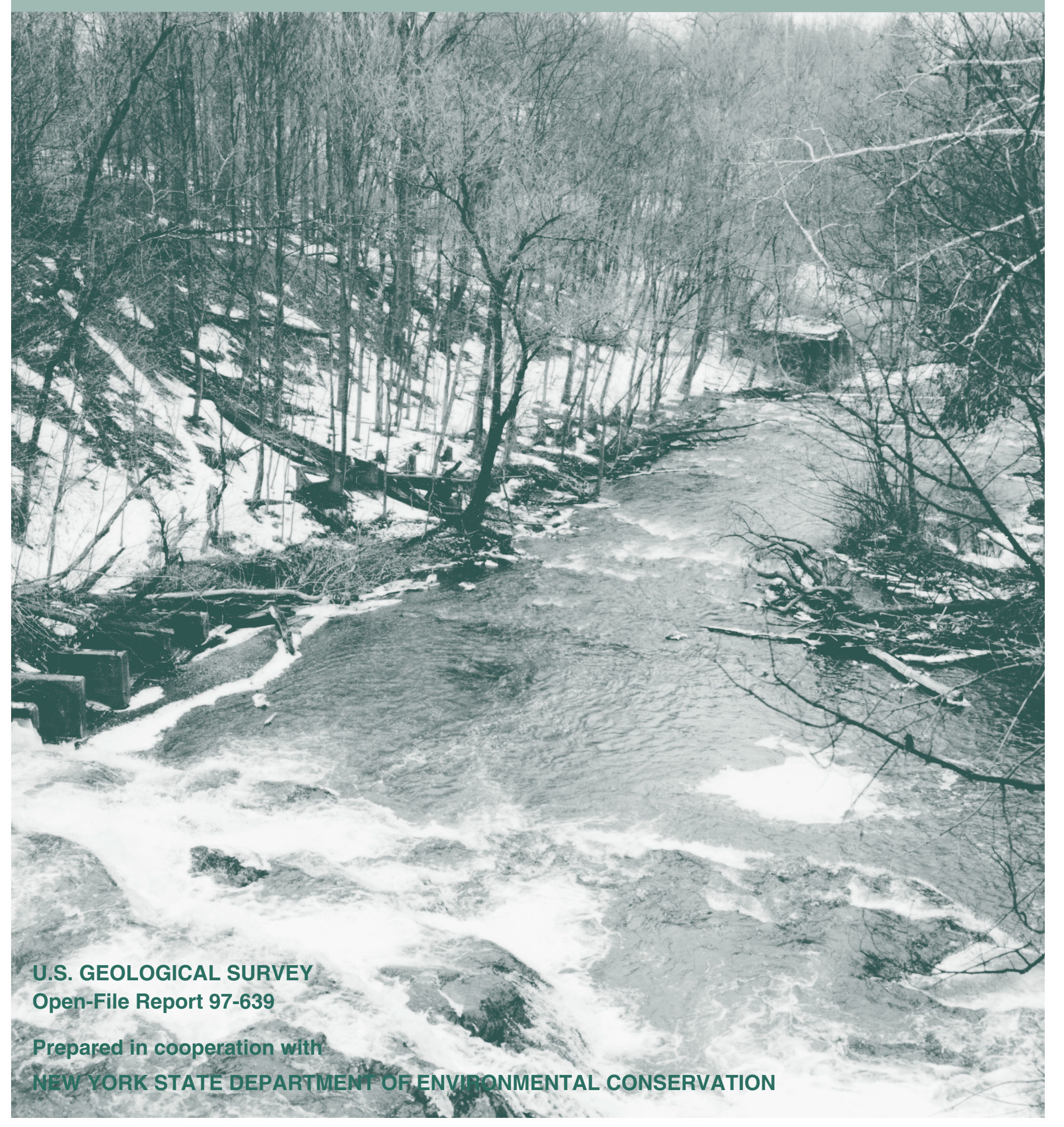


Cover: View of Moordener Kill from State Rt. 150 in Brookview, N.Y., looking west (downstream). Note exposed bedrock in streambed. (Photo by R.J. Reynolds, 1999). 


\section{Hydrogeology of the Schodack-Kinderhook Area, Rensselaer and Columbia Counties, New York}

By Richard J. Reynolds

U.S. GEOLOGICAL SURVEY

Open-File Report 97-639

Prepared in cooperation with the

NEW YORK STATE DEPARTMENT OF ENVIRONMENTAL CONSERVATION

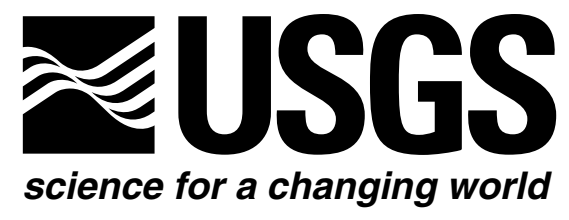




\title{
U.S. DEPARTMENT OF THE INTERIOR BRUCE BABBITT, Secretary
}

\author{
U.S. Geological Survey \\ Charles G. Groat, Director
}

For additional information

write to:

U.S. Geological Survey

425 Jordan Road

Troy, NY 12180-8349
Copies of this report may be purchased from:

U.S. Geological Survey

Branch of Information Services

P.O. Box 25286

Denver, CO 80225 


\section{CONTENTS}

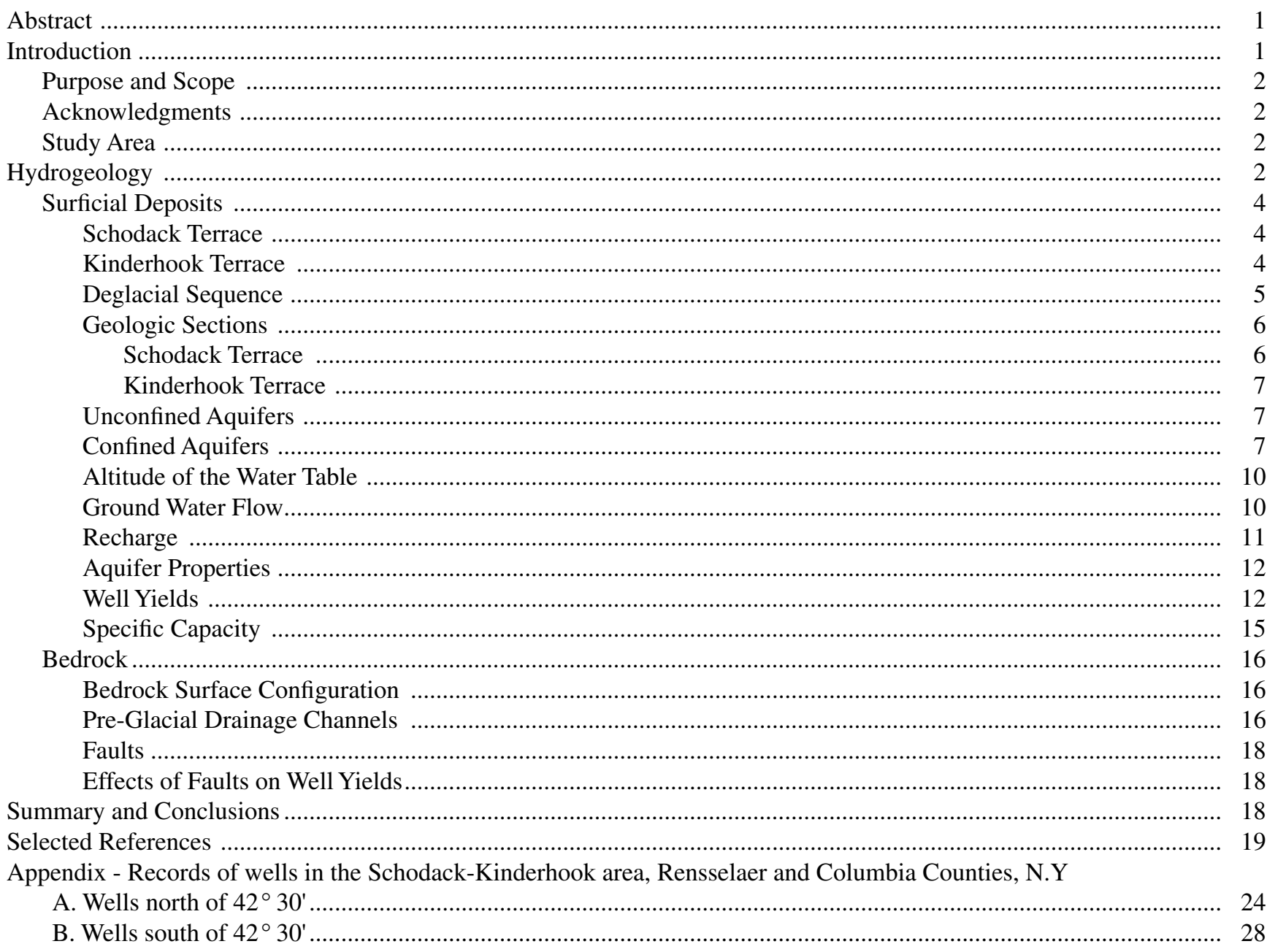

\section{PLATES (in pocket)}

Maps of study area in Rensselaer and Columbia County, N.Y., showing:

1. Locations of wells and test holes

2. Surficial geology

3. Water-table altitude

4. Bedrock-surface altitude

\section{FIGURES}

1. Map showing location and principal geographic features of study area in Rensselaer and Columbia Counties, N.Y...... 3

2. Hydrogeologic sections

a.Geologic section A-A' through the Schodack Terrace, Rensselaer, N.Y. …….................................................... 8

b. Geologic section B-B' through the Kinderhook Terrace, Columbia County, N.Y................................................ 9 
TABLES

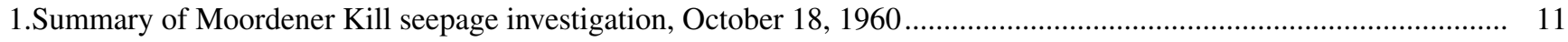

2. Summary of aquifer tests from Myrick and Associates (1960).....

3. Well yield, by water-use and aquifer type, for the Schodack-Kinderhook area, Rensselaer and Columbia

Counties, N.Y.

4. Reported specific capacity data, estimated transmissivity, and estimated hydraulic conductivity at selected wells in the Schodack-Kinderhook area, Rensselaer and Columbia Counties, N.Y.

\section{CONVERSION FACTORS, ABBREVIATIONS, AND VERTICAL DATUM}

\begin{tabular}{|c|c|c|}
\hline Multiply & by & To Obtain \\
\hline \multicolumn{3}{|c|}{ Length } \\
\hline inch (in.) & 2.54 & centimeter \\
\hline foot $(\mathrm{ft})$ & 0.3048 & meter \\
\hline mile $(\mathrm{m})$ & 1.609 & kilometer \\
\hline foot per mile $(\mathrm{ft} / \mathrm{mi})$ & 0.1894 & meter per kilometer \\
\hline \multirow{3}{*}{ square mile $\left(\mathrm{mi}^{2}\right)$} & Area & \\
\hline & 2.59 & square kilometer \\
\hline & Flow & \\
\hline cubic foot per second $\left(\mathrm{ft}^{3} / \mathrm{s}\right)$ & 0.02832 & cubic meter per second \\
\hline cubic foot per second $\left(\mathrm{ft}^{3} / \mathrm{s}\right)$ & 28.32 & liter per second \\
\hline gallon per minute (gal/min) & 0.06309 & liter per second \\
\hline million gallons per day (Mgal/d) & 0.04381 & cubic meters per second \\
\hline million gallons per day (Mgal/d) & 3,785 & cubic meters per day \\
\hline \multicolumn{2}{|l|}{ million gallons per day per square mile } & cubic meters per day per square kilometer \\
\hline \multicolumn{2}{|l|}{ gallons per day per square mile } & cubic meters per day per square kilometer \\
\hline \multirow[t]{2}{*}{ gallon per day per foot $[(\mathrm{gal} / \mathrm{d}) / \mathrm{ft}]$} & 0.0001437 & liter per second per meter \\
\hline & $\begin{array}{l}\text { Hydraulic } \\
\text { Units }\end{array}$ & \\
\hline transmissivity, feet squared per day $\left(\mathrm{ft}^{2} / \mathrm{d}\right)$ & 0.0929 & meter squared per day \\
\hline hydraulic conductivity, feet per day (ft/d) & 0.3048 & meter per day \\
\hline $\begin{array}{l}\text { specific capacity, gallons per minute per foot } \\
\qquad[(\mathrm{gal} / \mathrm{min}) / \mathrm{ft}]\end{array}$ & 0.2070 & liter per second per meter \\
\hline
\end{tabular}

Sea level:In this report, "sea level" refers to the National Geodetic Vertical Datum of 1929 (NGVD of 1929)--a geodetic datum derived from a general adjustment of the first-order level nets of the United States and Canada, formerly called Sea level Datum of 1929. 


\title{
Hydrogeology of the Schodack-Kinderhook Area, Rensselaer and Columbia Counties, New York
}

\author{
by Richard J. Reynolds
}

\section{ABstract}

Two glaciodeltaic outwash terraces in southern Rensselaer and northern Columbia Counties, known locally as the Schodack and Kinderhook terraces, consist of ice-contact and outwash sand and gravel and together form a regional, unconfined, stratified-drift aquifer with a combined area of 18.75 square miles. The hydrogeology of these aquifers is summarized on four maps at 1:24,000 scale, that depict (1) locations of wells and test holes, (2) surficial geology, (3) altitude of the water table, and (4) altitude of the bedrock surface.

Both terraces are associated with a thin and probably discontinuous confined aquifer consisting of beds of glaciofluvial sand and gravel derived from the outwash deltas that form the two terraces. The confined aquifer is overlain by thick deposits of lacustrine silt and clay. Consultants' estimates of average hydraulic conductivity, based on aquifer tests conducted at four test wells screened in thicker sections of the confined aquifer, range from 430 to 2,360 ft/d (feet per day), with a mean of $1,150 \mathrm{ft} / \mathrm{d}$. The mean estimate of hydraulic conductivity derived from specific-capacity data from 16 test wells screened in confined and unconfined sections of the aquifer is $640 \mathrm{ft} / \mathrm{d}$.

Reported yields for domestic wells completed in unconfined sections of the Schodack and Kinderhook terrace aquifers average 16.1 and $18.3 \mathrm{gal} / \mathrm{min}$ (gallons per minute), respectively, and reported yields of domestic wells completed in hydraulically confined sections of these terraces average 15.3 and $12.8 \mathrm{gal} /$ $\mathrm{min}$, respectively. Yields from public-supply wells screened in the confined sections of the Schodack Terrace aquifer range from 50 to $1,050 \mathrm{gal} / \mathrm{min}$ and average $305 \mathrm{gal} / \mathrm{min}$. Average annual recharge to the Schodack Terrace aquifer and adjacent upland till deposits, as estimated in a 1960 U.S. Geological
Survey study, were 16.3 and 7.1 inches per square mile, respectively. Bedrock that underlies the study area has been highly modified by tectonic activity, differential weathering, and preglacial erosion which produced about $900 \mathrm{ft}$ of relief on the bedrock surface. A major thrust fault that runs north-south through the area separates autocthonous Ordovician rock units to the west from allocthonous Cambrian (Taconic) rocks to the east.

\section{INTRODUCTION}

Most productive aquifers in upstate New York consist of unconsolidated deposits of glacial and alluvial sand and gravel that occupy major river and stream valleys or cover large areas as glaciodeltaic terraces or lacustrine sand plains. Ground water in these valley-fill or glaciodeltaic aquifers can occur under either water-table (unconfined) or artesian (confined) conditions. Farms, industries, or municipalities have been built over many of these aquifers because they typically form flat areas suitable for development and generally provide an ample ground-water supply. This development, coupled with the generally high permeability of these deposits and a typically shallow depth to the water table, makes these aquifers vulnerable to contamination from point sources such as landfills, road-salt stockpiles, hydrocarbon-fuel storage, and other industrial facilities with a potential for contaminant leakage, in addition to nonpoint sources such as urban and agricultural runoff and septic-tank leachate.

The USGS, in cooperation with the New York State Department of Health, began a study in 1980 to define the hydrogeology of 18 extensively used stratified-drift aquifers in upstate New York to facilitate water-management decisions by State and local government agencies. To date (1998), 15 of these 
aquifers have been studied and the results published as individual sets of maps (at 1:24,000 scale); results from the first 11 are summarized by Waller and Finch (1982) and the remaining four by Cosner (1984).

As a continuation of that project, the USGS, in cooperation with the New York State Department of Environmental Conservation, began a study in 1983 to investigate the hydrogeology of several additional extensively used stratified-drift aquifers in New York. Each report from both studies consists of a set of 1:24,000-scale (or larger) maps that describe the hydrogeology of a specific aquifer or area and depict selected hydrogeologic characteristics, such as well and test-hole locations, surficial geology, bedrocksurface altitude, geologic sections, land use, soil permeability, water-table or potentiometric-surface altitude, saturated thickness, and estimated well yields. The numbers of maps and topics differ among the reports, depending upon the amount of hydrogeologic data that was available for each particular area studied. To date (1998), 15 reports from this second series, including this one, have been published.

\section{Purpose and Scope}

This report and its four maps summarize the hydrogeology of the glaciodeltaic aquifers and the underlying bedrock in southwestern Rensselaer and northwestern Columbia Counties (fig. 1). The maps are based on available hydrogeologic data in USGS files and previously published reports and depict the following information: plate 1, locations of wells and test holes; plate 2, surficial geology; plate 3, altitude of the water table; and plate 4, altitude of the bedrock surface. A table of well records is included as an appendix.

\section{Acknowledgments}

The author thanks Dr. Robert G. LaFleur of Rensselaer Polytechnic Institute for making recently collected well data and well logs within the Town of Schodack available for inclusion in this report, and the Town of East Greenbush, for providing a copy of a consultant's report (Myrick and Associates, 1960).

\section{Study Area}

The two glaciodeltaic terraces described in this report encompass a combined area of $18.75 \mathrm{mi}^{2}$ in southern Rensselaer and northern Columbia counties (fig 1). These terraces consist of both ice-contact deposits, composed of esker and kame sand and gravel, and outwash fans, deposited as prograding sand and gravel deltas into glacial Lake Albany. The study area encompasses the Town of Schodack and the southern half of the Town of East Greenbush in Rensselaer County, as well as parts of the Towns of Stuyvesant, Kinderhook, and Chatham in Columbia County. Major population centers include the villages of East Greenbush, Schodack, Kinderhook, and Valatie. These towns, which are largely residential areas for employees working in the Albany area, have undergone rapid population growth in recent years. Concurrent with this growth, the demand for publicly supplied water to new housing developments has increased dramatically. For example, the Town of East Greenbush's population grew only 9 percent during 1980-90, from 12,913 to 14,076, but the number of housing units increased almost 21 percent. During the same period, the Town of Schodack's population increased 4.4 percent from 11,345 to 11,839 , but the number of housing units increased 11.8 percent (Capital District Regional Planning Commission, 1993, p. 28-29). Most of this demand can be met only by publicly-supplied or self-supplied ground water. The increasing demand for this resource has made aquifer delineation and protection a concern and has also created a need for hydrogeologic information to enable local and regional planning commissions, public water suppliers, and State water-regulatory agencies to prudently expand existing public watersupply service areas.

\section{HYDROGEOLOGY}

The Schodack-Kinderhook area is dominated by two large glaciodeltaic terraces--the Schodack and Kinderhook Terraces--that together form a large, regional unconfined aquifer that stretches $12.5 \mathrm{mi}$ north to south from the village of East Greenbush in Rensselaer County to the Valatie-Kinderhook area in Columbia County. This aquifer, and the associated confined sections, encompasses a combined area of $18.75 \mathrm{mi}^{2}$ and supplies groundwater to 12 public water 


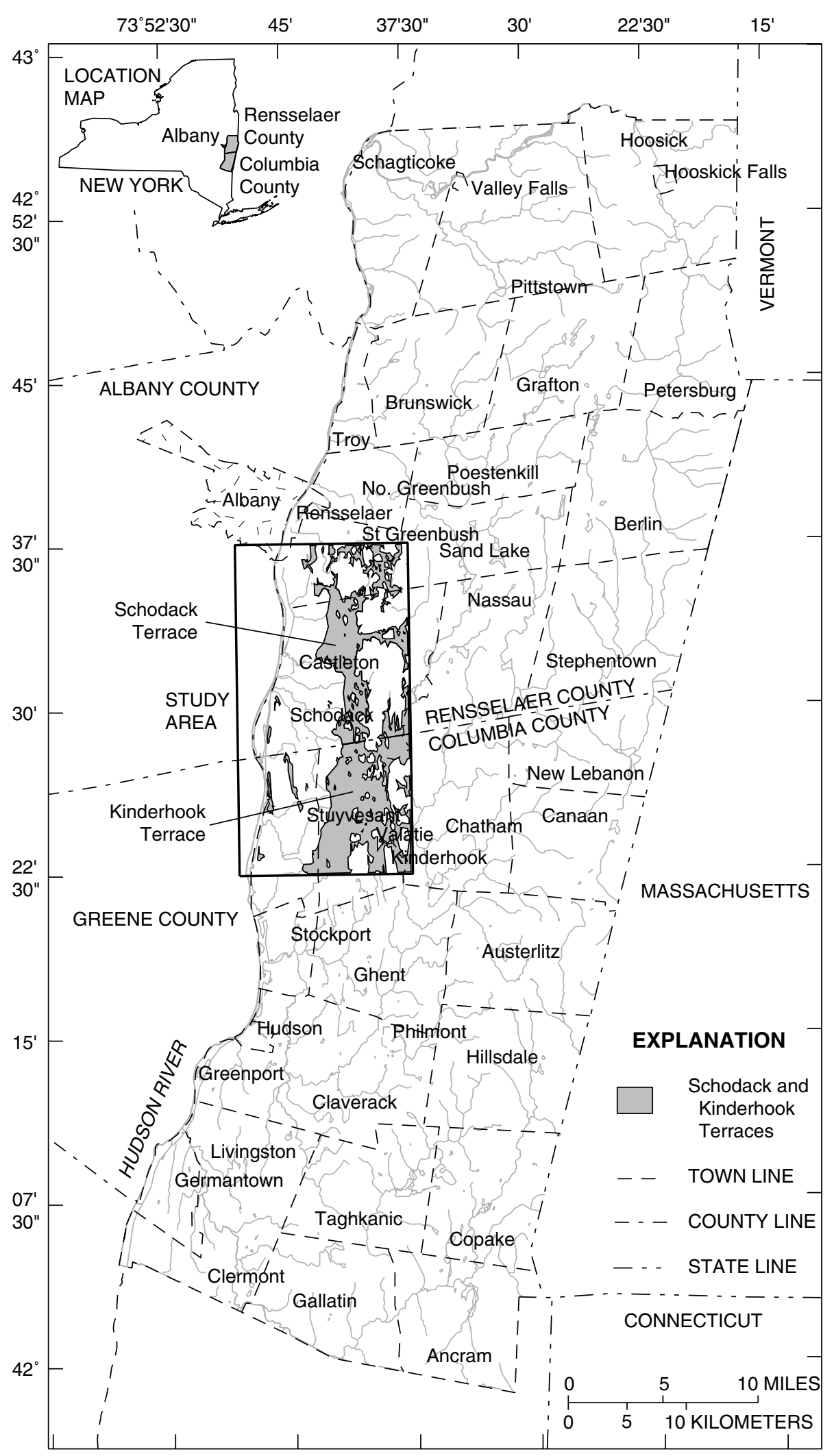

Base from U.S. Geological Survey digital data, 1:100,000, 1983,

Universal Transverse Mercator projetion, Zone 18

Figure 1. Location of study area within Rensselaer and Columbia counties and areal extent of Schodack and Kinderhook terraces (shaded). 
suppliers through 30 wells, and to many privatelyowned domestic wells.

The hydrogeology of these two terraces is described in this report in terms of surficial geology, morphogenesis, cross-sectional structure, distribution of unconfined and confined aquifers, water-table altitude, direction of groundwater flow, rate of recharge, hydraulic properties, and well yields.

The underlying bedrock is described in terms of surface altitude and topography, distribution of faults and preglacial drainage channels, and relation between faults and bedrock well yields.

\section{Surficial Deposits}

The areal distribution of Holocene and Pleistocene-age morphostratigraphic units that comprise the Schodack and Kinderhook terraces, as well as the distribution of ice-contact units in the adjacent uplands and lacustrine units in the Hudson Valley are shown on plate 2. The mapped area comprises the East Greenbush (1974), Kinderhook (1976), and parts of the Delmar (1983) and Ravena (1983) $7 \frac{1}{2} 2$-min quadrangles. The geologic mapping was done by Dr. Robert LaFleur of Rensselaer Polytechnic Institute in the 1960's and 70's, part of which (the East Greenbush quadrangle) is published in a New York State Museum Map and Chart Series report (LaFleur, 1965a).

\section{Schodack Terrace}

The Schodack Terrace, first named by Woodworth (1905), is a broad, flat-topped outwash and kame terrace, that encompasses about $9 \mathrm{mi}^{2}$ within the Towns of East Greenbush and Schodack in Rensselaer County (fig. 1). The terrace extends about $8 \mathrm{mi}$ from the northern end of the village of East Greenbush, south to the New York State Thruway interchange with the Berkshire Spur (I-90), where it merges with the slightly larger Kinderhook Terrace. The Schodack Terrace ranges from less than $0.5 \mathrm{mi}$ in width at its northern and southern ends to a maximum of about $2.4 \mathrm{mi}$ at its midpoint, where it is crossed by the Moordener Kill. The Schodack Terrace is bounded on its eastern edge by till-covered bedrock hills, and on its western side by its contact with lacustrine silt, sand, and clay. It consists of two major morphostratigraphic units: (1) a kame-and-esker sand and gravel unit (ksg and eg on pl. 2) that was deposited during the ice- contact phase of deglaciation, and (2) an outwash delta unit (osg on pl. 2) that was deposited during the subsequent lacustrine phase of deglaciation (LaFleur, 1961). The outwash unit was deposited as a prograding delta into glacial Lake Albany and, in some areas, overlies previously deposited ice-contact sand and gravel. As a result, this outwash delta now forms the widest and thickest section of the 8-mi-long terrace. The log of well Re-538 (pl. 1), just south of the Moordener Kill, shows a thickness of at least $112 \mathrm{ft}$ of sand and gravel at this location.

The surface of the Schodack Terrace is pitted with many small, closed depressions called "kettles," which formed where blocks of detached ice were buried during the ice-contact phase of deglaciation and later melted, leaving surface depressions. Many of these depressions on the terrace (and elsewhere in the study area) intersect the water table to form ponds, lakes, or swampy areas. These depressions typically are partly filled with peat or postglacial alluvium. A large iceblock depression in the outwash delta, southeast of Brookview and just north of the Vlockie Kill (pl. 2), is bordered by esker and ice-contact deposits and may show undisturbed ice-contact faces (LaFleur, 1961, p. A14). One of the largest ice-block depressions in the study area is now occupied by Kinderhook Lake, which is surrounded by deposits of kame and esker sand and gravel (pl. 2).

Throughout the length of the Schodack Terrace, the ice-contact deposits (ksg) and deltaic deposits (osg) are punctuated by till drumlins, as well as by previously deposited eskers and kames. Till-cored drumlins (tt) in the area generally display a strike (long-axis trend) of $\mathrm{N} 20^{\circ} \mathrm{W}$, indicating the predominant direction of ice movement, whereas bedrock-cored drumlins (also $t \mathrm{t}$ ) show strikes of northsouth to $\mathrm{N} 15^{\circ} \mathrm{E}$, which reflects the general structural trend of the bedrock (LaFleur, 1961, p. A-9).

\section{Kinderhook Terrace}

Little has been written about the deposits that form the Kinderhook Terrace. Cook (1943) was the first to describe some of the glacial features within the Kinderhook quadrangle, and LaFleur (1965a) makes a passing reference to it. The northern two-thirds of the Kinderhook Terrace is primarily an outwash terrace that was deposited over older ice-contact deposits and till, between a shrinking Hudson Valley ice tongue and the till uplands to the east. The southern third of the Terrace, however, was deposited as a prograding delta 
(ld) into the northward advancing glacial Lake Albany and around large, detached ice blocks. Cook (1943, p. 348) suggests that the part of the present-day Kinderhook Creek valley that is at an elevation of $190-200 \mathrm{ft}$, is a large former ice-block depression. This depression is ringed with ice-contact deposits, drumlins, and till uplands, and its western edge is marked with a steep ice-contact slope that can be traced from the hamlet of Sunnyside eastward to north of the village of Kinderhook. This steep ice-contact slope also forms the eastern edge of a large deltaic unit (ld) that forms the southern third of the Kinderhook Terrace. The meltwater drainage that produced this deltaic unit probably emanated from the upland areas of the Kinderhook and Kline Kill Creeks. The main outwash terrace, however, was probably fed by (1) meltwater flowing through ice tunnels or crevasses from the adjacent northeast-southwest trending ice front, and (2) meltwater from the Valatie Kill, which carried sand and gravel around the ice block that occupied the area of Kinderhook Lake at the time. This is evidenced by several prominent eskers at the northern end of the outwash terrace, just north of Knickerbocker Lake (also an ice-block depression) and eskers and ice-contact sand and gravel on the northern and eastern sides of Kinderhook Lake. The outwash terrace (osg) and adjacent lacustrine delta (ld) together form the Kinderhook Terrace and occupy an area of $9.75 \mathrm{mi}^{2}$, just slightly larger than the Schodack Terrace, to the north. Within the southern half of the mapped area, the Kinderhook Terrace abuts another $16 \mathrm{mi}^{2}$ of contiguous upland ice-contact and outwash sand and gravel deposits. Much like the Schodack Terrace, the surface of the Kinderhook Terrace is pitted with several small kettles that are now partly filled with postglacial alluvium. LaFleur (1965a, p. 6) notes that the Kinderhook Terrace is, at least in part, older than the Schodack Terrace to the north. The southern half of the Kinderhook Terrace (the lacustrine delta) may have been partly contemporaneous with early depositional phases of the Schodack Terrace.

\section{Deglacial Sequence}

The Kinderhook outwash terrace (elevation $310 \mathrm{ft}$ ) was almost completely formed before the southern end of the Schodack Terrace began to develop. Meltwater from the glacial Vlockie Kill and small tributary streams draining the ice-plugged Moordener Kill valley near East Schodack drained southward and westward into the Vlockie Kill drainage to deposit the outwash terrace between the present-day Vlockie Kill and the I-90 interchange. The expanding terrace at this time consisted of outwash, kame sand and gravel, and esker gravel deposits that formed between the till uplands and the shrinking Hudson Valley ice tongue. The ice terminus at this time was probably located somewhere between Schodack and Kinderhook. As the ice tongue receded northward, glacial Lake Albany spread northward also, forming an embayment between the southwestnortheast-trending ice front and the till uplands to the east. As the ice recession continued, the Moordener Kill became unblocked at Schodack Center (Rice Corners); the ice margin at that time trailed off to the southwest from Rice Corners along the present course of the Moordener Kill. This former ice margin is now marked by several deposits of esker gravel on both sides of the Moordener Kill valley (LaFleur, 1965a, p. 11). Subsequently, large volumes of meltwater from the ice-free Moordener Kill eroded the kame sand and gravel deposits in the upper reaches of its valley and redeposited them as an outwash delta (osg) of sand and gravel that eventually prograded $2 \mathrm{mi}$ southwestward into Lake Albany from its origin at Rice Corners. The surface elevation of glacial Lake Albany at this time was $330 \mathrm{ft}$ (LaFleur, 1965a). This outwash delta now forms the widest and thickest section of the 8-mi-long Schodack Terrace aquifer.

At the same time that the Moordener Kill outwash delta was being deposited, the North Branch Moordener Kill became unblocked, and subsequent glacial meltwater deposited a large area of outwash (osg) and kame-terrace sand and gravel (ksg) between East Greenbush and Schodack Center. This deposition of kame and outwash eventually expanded southward to abut the Moordener Kill outwash delta, where it today forms the northern part of the Schodack Terrace aquifer. Remnants of eskers that once fed this kame terrace can be seen just west and south of the hamlet of East Greenbush.

As the ice margin receded to the north, allowing glacial Lake Albany to spread northward as far as Couse Corners, meltwater from the ice margin deposited a southeastward-prograding kame delta (the Hampton Park kame delta) just north of Sherwood Park. Subsequent northward retreat of the ice margin allowed glacial Lake Albany to spread northwest of this delta, where it accumulated lake clay and reworked the western edge of this kame delta into a prominent beach (LaFleur, 1965a, p. 11). The 
bottomset lacustrine sands of the Hampton Park kame delta abut the older kame gravel of the Schodack Terrace at its northern margin between Sherwood Park and East Greenbush. The Hampton Park kame delta was deposited when glacial Lake Albany was at an elevation of $350 \mathrm{ft}$ (LaFleur, 1965a, p. 11).

As the ice receded north of the Hampton Park area, the level of glacial Lake Albany dropped again to about $330 \mathrm{ft}$. During this time, wave action reworked the kame and outwash deposits of the Schodack Terrace into a prominent beach. The western edge of the Schodack Terrace is defined by these beach gravels (bsg), which extend from East Greenbush south to the Moordener Kill and then from the Vlockie Kill south to Bame Road in the Town of Schodack (pl. 2). These beach deposits tended to form most conspicuously on northwest-facing exposures of the Schodack Terrace, which were evidently open to a fairly large expanse of glacial Lake Albany. LaFleur (1965a) notes that the southernmost of the two beach deposits is at an elevation of $320 \mathrm{ft}$, whereas the northern section is at a slightly higher elevation of $330 \mathrm{ft}$, as a result of isostatic rebound of about $2.5 \mathrm{ft} / \mathrm{mi}$ after the removal of ice. These beach gravels are mostly underlain by westward-dipping foreset beds of the kame delta (LaFleur, 1961).

With the subsequent draining of glacial Lake Albany to near present-day levels, the postglacial Moordener Kill incised a steep-walled valley though the widest part of the Schodack Terrace, downcutting as much as $100 \mathrm{ft}$ into the outwash delta and exposing bedrock in several places. Coarse esker gravel that marks the location of a former ice margin forms segments of this steep valley wall in areas. Modern postglacial alluvium of reworked outwash now floors the Moordener Kill flood plain, which is as much as $1800 \mathrm{ft}$ wide. Similarly, the postglacial Vlockie and Muitzes Kill drainage systems have eroded an extensive network of stream channels through the Lake Albany lacustrine sand and underlying clay, exposing bedrock at many places and at their nickpoints where they enter the Hudson River gorge.

\section{Geologic Sections}

Two geologic sections through the Schodack and Kinderhook terraces were constructed to illustrate the stratigraphic relationships of the geologic units shown on plate 2. Section A-A' stretches $4.2 \mathrm{mi}$ across the Schodack terrace and trends southwest-to-northeast from the Vlockie Kill to Rice Corners; Section B-B' stretches $5.2 \mathrm{mi}$ west-to-east across the Kinderhook Terrace from Stuyvesant Brook to the bedrock uplands south of Niverville. The traces of these sections are shown on plate 1 .

\section{Schodack Terrace}

Section A-A' (fig. 2a) extends from southwest to northeast through the Schodack Terrace and shows the stratigraphic relation between the outwash sand and gravel (osg) that forms the Schodack outwash delta, and the underlying ice-contact and lacustrine deposits. At the eastern (right) end of the section, the outwash sand and gravel is underlain by large thicknesses of esker and kame sand and gravel. In some areas, notably within the Moordener Kill valley, about $15 \mathrm{ft}$ of lacustrine silt and clay is interposed between the outwash and the underlying ice-contact sand and gravel. The trace of this section cuts across two prominent eskers emplaced along the Moordener Kill valley (plate 2); these represent some of the thickest deposits; of sand and gravel within the Schodack Terrace. The thickness of sand and gravel beneath these eskers ranges up to $150 \mathrm{ft}$, but only the lower 70 to $80 \mathrm{ft}$ are saturated. Southwest of these eskers, the surficial outwash sand and gravel (osg) overlies as much as $140 \mathrm{ft}$ of lacustrine silt, sand, and clay (lss and lsc). Although the surficial outwash unit (osg) is between 70 and 80 feet thick here, its saturated thickness is only about $10 \mathrm{ft}$ in areas where it is underlain by Lake Albany lacustrine silt and clay. Further west along section A-A', the surficial outwash is again underlain by buried kame sand and gravel, and results in a combined thickness of up to $150 \mathrm{ft}$ in places. In this area, the saturated thickness of combined outwash and kame sand and gravel may range from 90 to $120 \mathrm{ft}$, partly because of a dip in the underlying bedrock surface. West of the surficial outwash unit (osg) that defines the limit of the Schodack Terrace, section A-A' shows thin lacustrine sand and silt (lss) overlying slightly thicker deposits of lacustrine silt and clay (lsc). These units overlie a small deposit of kame sand and gravel that occupies a bedrock trough east of the Vlockie Kill valley.

The locations of three thrust faults - the Rysedorph, Ferry St., and Logan's Line faults—are also shown on Section A-A'. These faults have little or no exposure at land surface, therefore, the dips of these faults are not accurately known. Elam (1960) states that the only exposure of the Logan's Line fault on the East Greenbush quadrangle is in the Vierda Kill 
valley, where it displays a strike of $\mathrm{N} 10^{\circ} \mathrm{E}$ and an eastward dip of $70^{\circ}$. Elam (1960, p. 99-102) suggests that, like Logan's Line, both the Rysedorph and Ferry St. faults are high-angle faults at the surface, and that their eastward dip flattens with depth. Thus, the dips of these fault planes as shown in Section A-A' is only an approximation used to illustrate their locations along the section line.

\section{Kinderhook Terrace}

Section B-B' (fig. 2b) extends from west to east across the Kinderhook Terrace from west of Stuyvesant Brook to the bedrock uplands east of the Valatie Kill. Section B-B' indicates that whereas the stratigraphy of the Kinderhook Terrace is similar to that of the Schodack Terrace, its overlying surficial outwash sand and gravel is thinner. The outwash sand and gravel unit (osg) that defines the Kinderhook Terrace is about 20 feet thick throughout most of section B-B' and ranges up to $40 \mathrm{ft}$ thick at the eastern end of the section. Within and adjacent to the Valatie Kill valley, the outwash is underlain by 15 to 20 feet of ice-contact sand and gravel (ksg). In the center of the section, the thin outwash (osg) is underlain by as much as 150 feet of lacustrine sand, silt, and clay (lss and lsc units). Beneath the lacustrine silt and clay unit (lsc) is a thin (less than $10 \mathrm{ft}$ thick) confined sand and gravel aquifer (fd) that probably represents either subaquatic fan deposits or proximal bottomset beds of the prograding outwash delta. This confined aquifer provides adequate water supplies to several drilled domestic wells in the area. At the western end of the section, the lacustrine sand unit pinches out to leave only 15 to $20 \mathrm{ft}$ of lacustrine silt and clay (lsc) overlying bedrock. A minor thrust fault, one of a series of parallel thrust faults that pass through the region, is shown on the right side of section B-B'.

\section{Unconfined Aquifers}

Both the Schodack and Kinderhook Terraces consist primarily of outwash sand and gravel that was deposited as prograding outwash deltas into glacial Lake Albany. These surficial outwash units provide an extensive, unconfined (water-table) aquifer where they are sufficiently saturated. The greatest unconfined saturated thickness occurs in areas where the outwash is directly underlain by ice-contact (kame or esker) sand and gravel (see section A-A'). Conversely, the unconfined-outwash aquifer is only thinly saturated or, in some places, may be completely unsaturated in areas where the outwash is relatively thin and overlies comparatively thick sections of fine-grained lacustrine sediments, as in the Kinderhook Terrace (section B-B'). Typically, the water table in these areas is within the underlying lacustrine sediments. Section B-B' through the Kinderhook Terrace shows the extent of the unconfined aquifer (units osg and ksg) and the approximate average altitude of the water table. Note that the altitude and slope of the water table are largely controlled by the presence of major streams, such as the Moordener and Vlockie Kills in the Schodack Terrace and the Valatie Kill, Kinderhook Creek, and Stuyvesant Brook in the Kinderhook Terrace. Section B-B' shows the location of a major ground-water divide (just to the right of well Cb-1059); ground water to the east of this divide moves eastward toward the Valatie Kill, and ground water to the west moves westward through the lacustrine sediments and ultimately to Stuyvesant Brook.

Although the surficial outwash unit in the Schodack Terrace has more than twice the thickness of the surficial outwash unit in the Kinderhook Terrace (compare sections A-A' and B-B'), its saturated thickness above the underlying lacustrine sediments is less than that of the Kinderhook Terrace. This is a result of the relatively low altitude of the streambed of the nearby Moordener Kill, which is the primary discharge point for ground water stored in the adjacent Schodack Terrace aquifer. The Moordener Kill is deeply incised across the Schodack Terrace, and thus provides a large ground-water drain, which significantly alters the natural ground-water flowpaths within the unconfined Schodack Terrace aquifer (see pl. 3, water-table altitude). Recharge to the surficial outwash aquifer here is balanced by continuous ground-water discharge to the Moordener Kill; thus, the average water-table profile (section A-A') represents an equilibrium condition in which the thickness of the unsaturated zone of the surficial outwash aquifer approaches $65 \mathrm{ft}$ in some places (see section A-A'). Seasonal variations in recharge to the surficial aquifer can be expected to cause annual water table fluctuations of about 5 feet, however.

\section{Confined Aquifers}

Several domestic wells and test holes west and southwest of the Schodack Terrace have been drilled through the overlying Lake Albany silt and clay and terminate in several feet of sand and gravel 


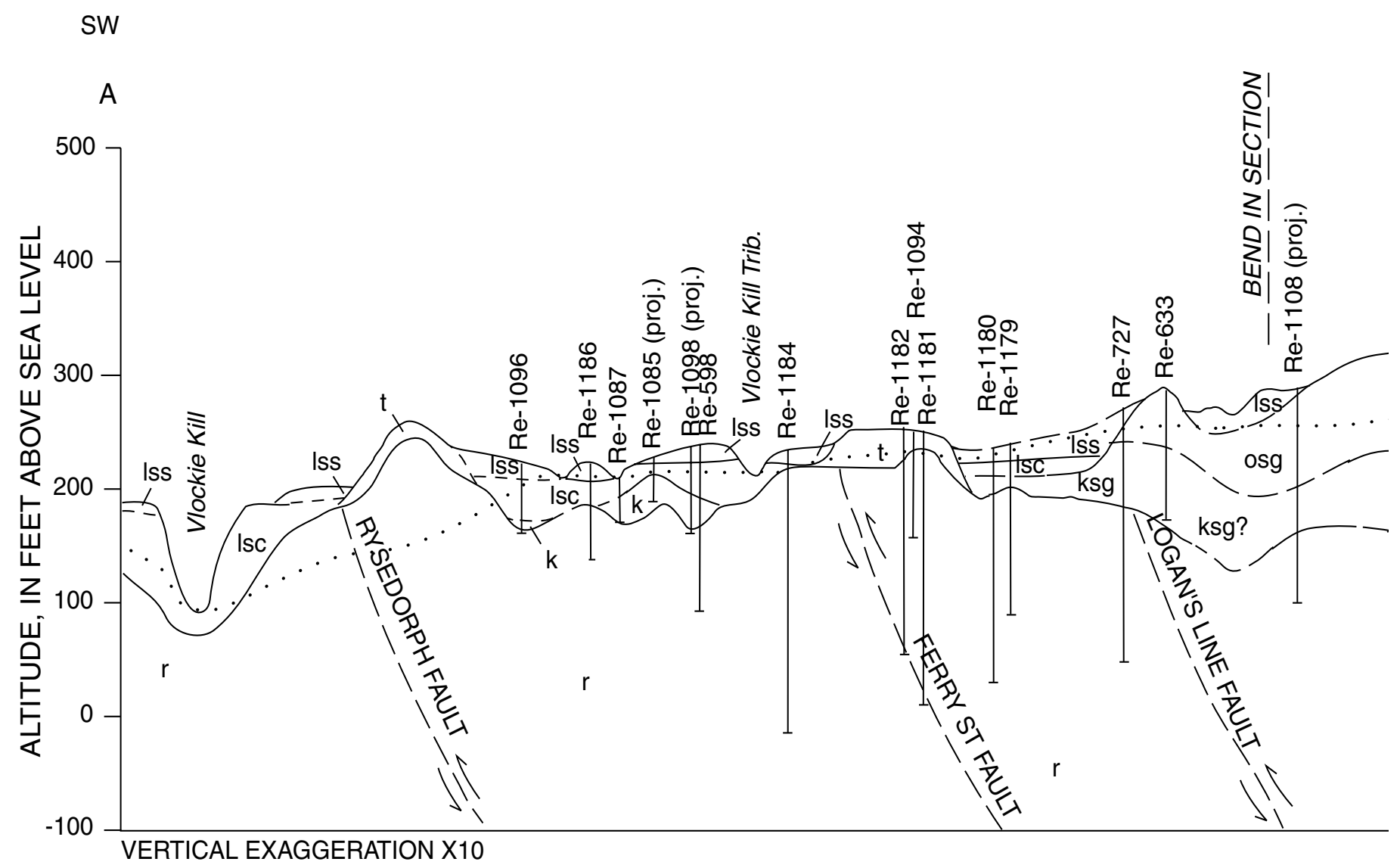

Complete descriptions of these stratgraphic units are given on plate 2 .
al ALLUVIUM
Is LACUSTRINE SAND
IsS LACUSTRINE SAND AND SILT
ISC LACUSTRINE SILT AND CLAY
osg OUTWASH SAND AND GRAVEL

Figure 2A. Geologic section A-A' through the Schodack Terrace, Rensselaer County, New York 


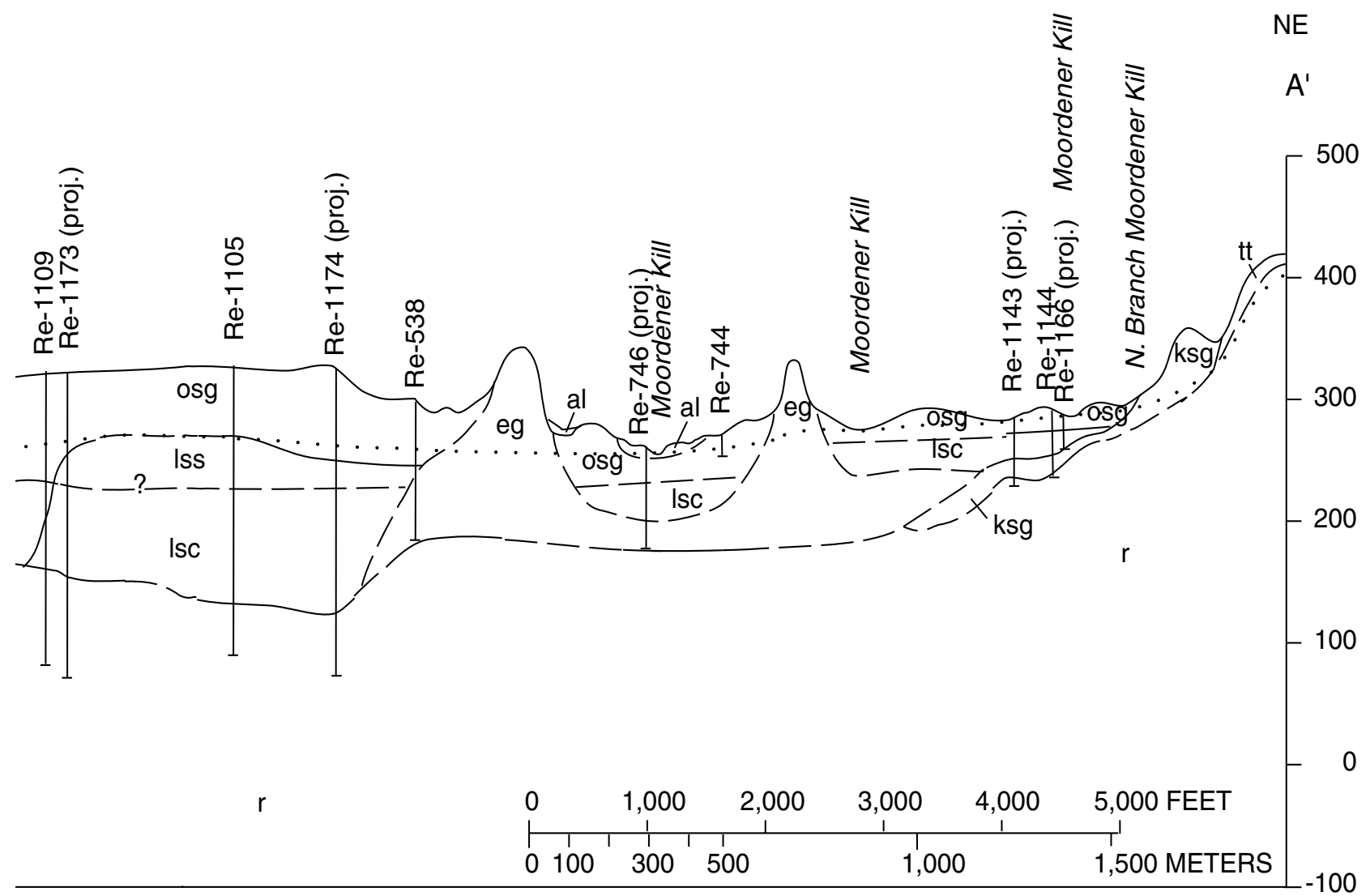

EXPLANATION

ksg KAME SAND AND GRAVEL

eg ESKER GRAVEL

$\mathrm{t} \quad$ TILL (GROUND MORAINE)

tt $\quad$ THICK TILL

$r \quad$ BEDROCK $\cdots \quad$ AVERAGE WATER TABLE

— GEOLOGIC CONTACT, dashed where inferred

- - THRUST FAULT, approximately located

I WELL OR TEST BORING

Figure 2A. (Continued) Geologic section A-A' through the Schodack Terrace, Rensselaer County, New York 


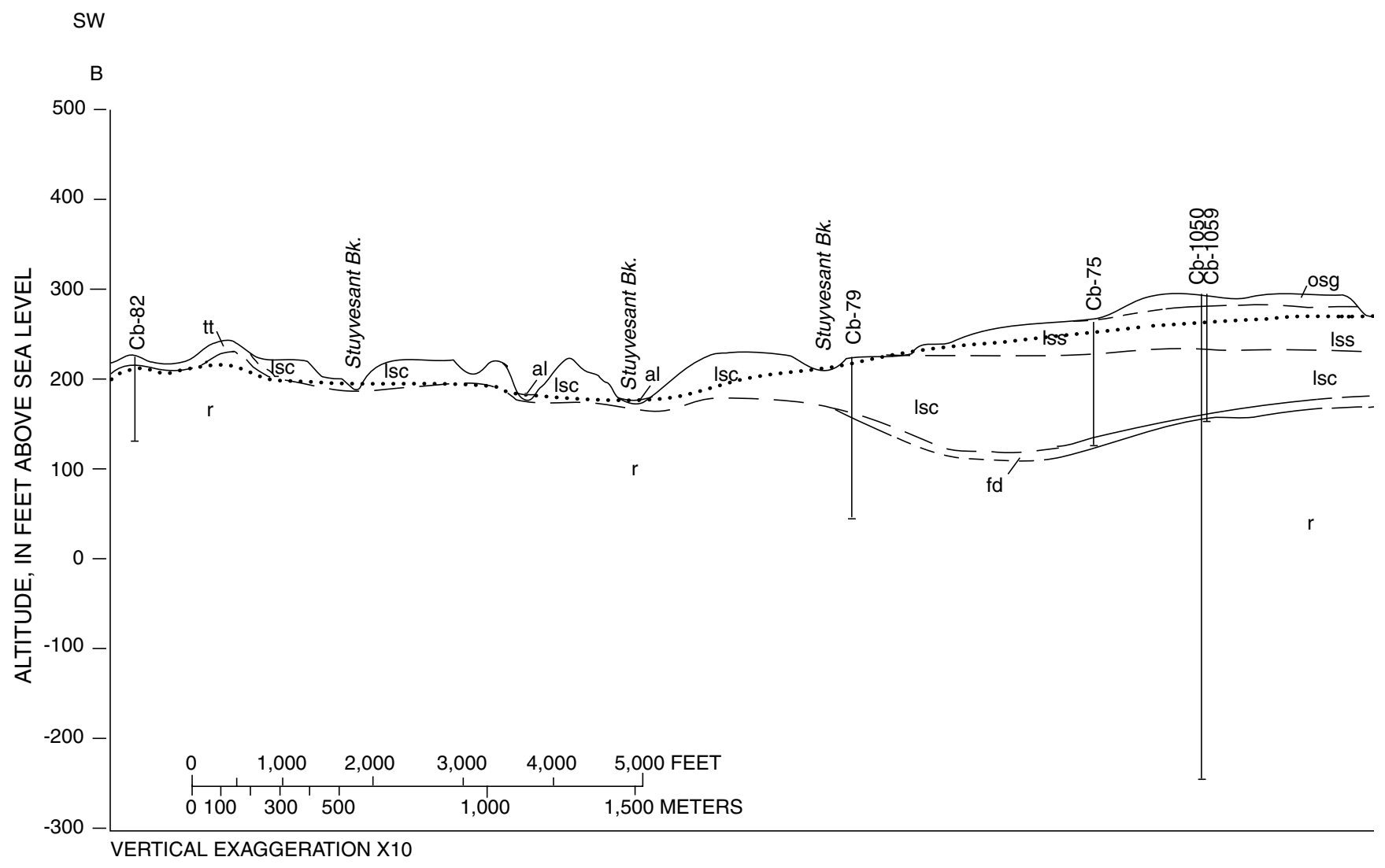

Complete descriptions of these stratgraphic units are given on plate 2 .

$\begin{array}{cl}\text { al } & \text { ALLUVIUM } \\ \text { Is } & \text { LACUSTRINE SAND } \\ \text { Iss } & \text { LACUSTRINE SAND AND SILT } \\ \text { Isc } & \text { LACUSTRINE SILT AND CLAY } \\ \text { fd } & \text { SUBAQUATIC FAN DEPOSITS OF SAND AND GRAVEL }\end{array}$

Figure 2B. Geologic section B-B' through the Kinderhook Terrace, Columbia County, New York 


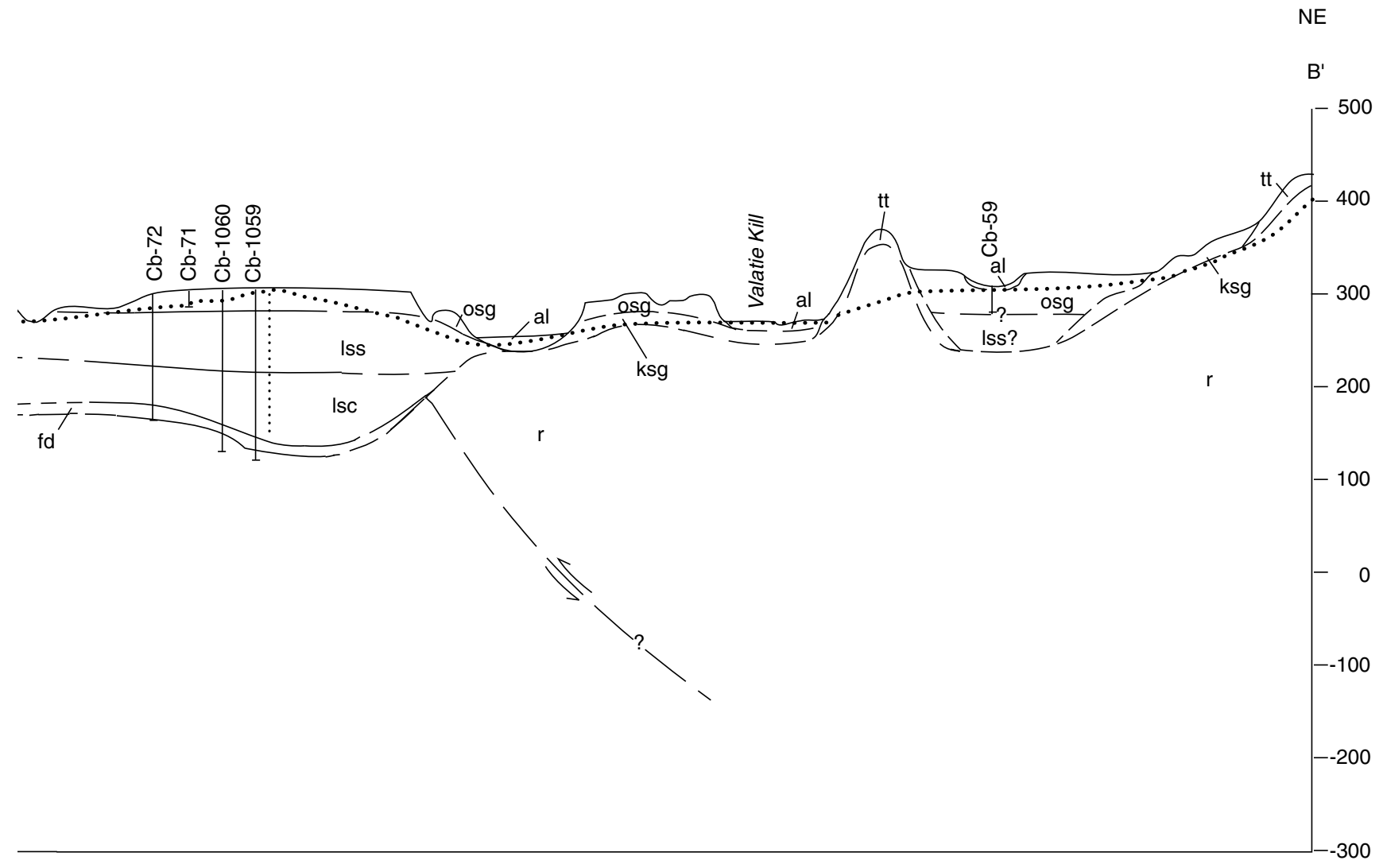

EXPLANATION

$\begin{array}{cl}\text { osg } & \text { OUTWASH SAND AND GRAVEL } \\ \mathrm{ksg} & \text { KAME SAND AND GRAVEL } \\ \mathrm{tt} & \text { THICK TILL } \\ \mathrm{r} & \text { BEDROCK } \\ \ldots & \text { AVERAGE WATER TABLE }\end{array}$

GEOLOGIC CONTACT, dashed where inferred

$\stackrel{\leftrightarrows}{\leftrightarrows}$ THRUST FAULT, approximately located

WELL OR TEST BORING

: GROUND-WATER DIVIDE, approximately located

Figure 2B. (Continued) Geologic section B-B' through the Kinderhook Terrace, Columbia County, New York 
immediately overlying bedrock (sheet 1). Several drillers have been able to exploit this thin confined aquifer and are able to obtain yields averaging $10 \mathrm{gal} /$ min through open-ended casing (Cushman, 1950, p. 20). This thin confined aquifer probably consists of either the proximal bottomset beds of the outwash delta that forms the widest part of the Schodack Terrace, or subaquatic fan deposits from an earlier icemarginal position. This confined aquifer is probably not areally extensive, and its western limit is probably defined by the bedrock ridge that extends southward from Grandview Hill to Brookview, then southeast to South Schodack. LaFleur (1961, p. A15) suggests that this ridge may have been a point at which the ice margin lingered during the glacial Lake Schodack phase of deposition. This confined aquifer, if present, is probably thickest where it occupies buried bedrock channels. Two such channels, one trending north-south just east of the limiting bedrock ridge and another trending east-west just south of the Moordener Kill, are cut to as low as 50 to $100 \mathrm{ft}$ above sea level (sheet 4). One well, Re-1112 at Brookview, is near the junction of these two channels and terminates in confined gravel at a depth of 140 feet and yields about $80 \mathrm{gal} / \mathrm{min}$. Another major bedrock channel extends eastward for about $3 \mathrm{mi}$ from the Hudson River gorge, and is approximately $1.3 \mathrm{mi}$ southwest of South Schodack (sheet 4). Two wells on either side of this channel, Re-1266 on the northeast side and Re-1267 on the southwest side (sheet 1), are completed in confined sand and gravel above bedrock. At least $25 \mathrm{ft}$ of confined sand and gravel is reported for well Re-1266, but only $10 \mathrm{ft}$ of confined gravel is reported for well Re-1267. Three supply wells, about $1 \mathrm{mi}$ north of South Schodack and owned by the Maple Hill Water Company (Re-1187, 1188, 1189) also are completed in this thin confined aquifer. These wells are either 6 or 8 in. in diameter, are screened in 13 to $15 \mathrm{ft}$ of fine gravel, and have yields ranging from 50 to $275 \mathrm{gal} / \mathrm{min}$.

The Kinderhook Terrace, like the Schodack Terrace, is also underlain in places by a thin confined gravel aquifer. Several domestic wells in Columbia County (Cb-10, 12, 68, 69, 70, 72, 75, 96, and 1049) (sheet 1) ranging in depth from 70 to $138 \mathrm{ft}$ penetrate the thin surficial outwash and the underlying lacustrine sand, silt, and clay and are completed in a confined coarse gravel aquifer that directly overlies bedrock. This coarse gravel aquifer probably represents the subaquatic-fan deposits or the proximal bottomset beds of the Kinderhook outwash delta and is less than $5 \mathrm{ft}$ thick in most places. The wells that are completed in this confined aquifer extend south about $2.5 \mathrm{mi}$ from Knickerbocker Lake to Bishop Nelson Road. The western limit of this aquifer is unknown but it probably underlies at least the eastern part of the adjacent lacustrine sand unit (lss) west of the Kinderhook outwash terrace (osg). Yields from nine domestic wells completed in this aquifer range from 2.5 to $25 \mathrm{gal} / \mathrm{min}$ and average $12.6 \mathrm{gal} / \mathrm{min}$, and all but one of these wells is finished open ended. Section B-B' (fig. 26) shows the stratigraphic relation of this confined aquifer to the overlying geologic units.

\section{Altitude of the Water Table}

The water-table altitude in an unconfined aquifer is the static level to which ground water rises in tightly cased shallow wells that extend a few feet into the zone of saturation. Streams and rivers that are fed by ground water also reflect the approximate water-table altitude during dry weather stream flow conditions (baseflow). The average altitude of the water table in the unconfined Schodack and Kinderhook aquifers and adjacent lacustrine sediments is depicted on plate 3 . The map was constructed from (1) historical waterlevel data from shallow drilled and dug wells obtained from driller's records that were collected during well inventories of Rensselaer and Columbia counties in the late 1940's (Cushman, 1950; Arnow, 1951), (2) water-level measurements made by the USGS in selected wells during a well inventory in the 1960's, (3) recent water-level measurements at selected wells (LaFleur, 1993), and (4) the elevation of stream surfaces as indicated by the topographic base map.

\section{Ground-water flow}

The general direction of ground water flow in the Schodack Terrace aquifer and adjacent lacustrine sediments is westward, toward the Hudson River valley. Two major stream networks--the Moordener Kill and its tributary, the Vlockie Kill--bisect the Schodack Terrace aquifer from east to west. These streams act as major ground water drains for the aquifer and significantly alter the directions of groundwater flow in the Schodack Terrace aquifer. Results of a seepage investigation conducted by the USGS on October 18, 1960 on the Moordener Kill (data summarized in table 1) indicates that the 16,000-ft stream reach from New York State Route 9 
Table 1. Summary of Moordener Kill seepage investigation, October 18, 1960.

[Site locations shown on plate 1; data from J.F. Joyce, U.S. Geological Survey. 1960, written commun.; $\mathrm{ft}^{3} / \mathrm{s}$, cubic feet per second; $\mathrm{mi}^{2}$, square miles; ft, feet; n.a., not applicable.]

\begin{tabular}{|c|c|c|c|c|c|c|c|}
\hline $\begin{array}{l}\text { USGS site } \\
\text { number }\end{array}$ & $\begin{array}{c}\text { Distance } \\
\text { upstream } \\
\text { from gage } \\
\text { (ft) }\end{array}$ & Site name & $\begin{array}{c}\text { Topographic } \\
\text { drainage area } \\
\left(\mathrm{mi}^{2}\right)\end{array}$ & $\begin{array}{c}\text { Measured } \\
\text { discharge } \\
\left(\mathrm{ft}^{3} / \mathrm{s}\right)\end{array}$ & $\begin{array}{c}\text { Net gain } \\
\text { within } \\
\text { reach } \\
\left(\mathrm{ft}^{3} / \mathrm{s}\right)\end{array}$ & $\begin{array}{l}\text { Length } \\
\text { of } \\
\text { reach } \\
\text { (ft) }\end{array}$ & $\begin{array}{c}\text { Ground- } \\
\text { water gain } \\
\text { per } 1,000 \mathrm{ft} \text { of } \\
\text { channel } \\
\left(\mathrm{ft}^{3} / \mathrm{s}\right)\end{array}$ \\
\hline 013597.50 & 0 & $\begin{array}{l}\text { Moordener Kill at Castleton-on- } \\
\text { Hudson }\end{array}$ & 32.6 & $17 *$ & 1.54 & 7,000 & 0.22 \\
\hline 013597.40 & 7,500 & $\begin{array}{l}\text { Moordener Kill Tributary near } \\
\text { Brookview, N.Y. }\end{array}$ & 0.46 & .058 & n.a. & n.a. & n.a. \\
\hline 013597.30 & 7,000 & $\begin{array}{l}\text { Moordener Kill at Brookview, } \\
\text { N.Y }\end{array}$ & 29.7 & 15.4 & 2.8 & 16,000 & 0.175 \\
\hline 013596.50 & 23,450 & $\begin{array}{l}\text { Moordner Kill at Schodack Cen- } \\
\text { ter, N.Y. }\end{array}$ & 13.7 & 6.0 & n.a. & n.a. & n.a. \\
\hline \multirow[t]{2}{*}{013596.60} & 23,150 & $\begin{array}{l}\text { North Branch Moordener Kill at } \\
\text { Schodack Center, N.Y. }\end{array}$ & 13.3 & 6.6 & n.a. & n.a. & n.a. \\
\hline & $\begin{array}{l}23,000 \text { to } \\
\text { confluence }\end{array}$ & $\begin{array}{l}\text { Combined flow of } 013596.5 \text { and } \\
013596.6\end{array}$ & na & 12.6 & n.a. & n.a. & n.a. \\
\hline
\end{tabular}

* mean daily discharge

(site 013596.50, at the confluence with the North Branch Moordener Kill) to Brookview (site 013597.30) displays a ground water seepage gain of $2.8 \mathrm{ft}^{3} / \mathrm{s}$ under baseflow conditions. This relatively large gain reflects the high permeability of the outwash sand and gravel that underlies this reach, as do the sharp inflections in the water-table contours (see pl. 3), which indicate ground water flow horizontally perpendicular to this stream reach.

Ground water in the Kinderhook Terrace aquifer flows in two directions from a prominent ground-water divide that runs generally northeast-southwest from just to the west of Kinderhook Lake, parallel to Kinderhook Creek to the hamlet of Sunnyside (pl. 3). Ground water east of this divide moves generally east and southeastward, toward Kinderhook Lake and, further south, toward Kinderhook Creek. Ground water west of this divide moves generally northwestward towards the Muitzes Kill drainage or west and southwestward toward the Stuyvesant Brook drainage. A secondary east-west ground-water divide separates ground water moving northward to the Muitzes Kill drainage from ground water moving southward to the Stuyvesant Brook drainage.

\section{Recharge}

Regional rates of recharge to sand and gravel and till deposits in southwestern Rensselaer county were estimated during a 1959-60 reconnaissance study of the Schodack Terrace aquifer by J.F. Joyce (U.S. Geological Survey, 1960, written commun.), who used a technique later documented by Randall and others (1966). The method uses a relationship developed between water levels in an observation well screened in the Schodack Terrace aquifer and corresponding flow of the Moordener Kill as measured at the gaging station at Castleton-on-Hudson. Joyce then used this "ground-water-rating curve" to synthesize a 1958-60 base-flow hydrograph for the Moordener Kill, based on average daily discharges at the gaging station, and determined from the baseflow hydrograph that the average daily ground-water discharge to the Moordener Kill for 1960 was $16.9 \mathrm{ft}^{3} / \mathrm{s}$. Because this average daily ground-water yield represented the combined ground-water discharge from outwash sand and gravel, fine-grained lacustrine sediments, and adjacent upland till, additional streamflow measurements at Brookview and at the confluence of the North Branch and main stem Moordener Kill were used to differentiate the relative contributions from 
sand and gravel and upland till. On October 18, 1960 a streamflow gain of $2.8 \mathrm{ft}^{3} / \mathrm{s}$ was measured for a 16,000 ft reach of the Moordener Kill between Rt. 9 (site 013596.50) and Brookview (site 013597.30) (Table 1). This $2.8 \mathrm{ft}^{3} / \mathrm{s}$ represented 18.2 percent of the total flow measured in the Moordener Kill at

Brookview. Joyce assumed that this percentage of ground water discharge was relatively constant, and estimated the average daily groundwater discharge to the Moordener Kill at Castle-on-Hudson for 1960 as 18.2 percent of $16.9 \mathrm{ft}^{3} / \mathrm{s}$, or $3.4 \mathrm{ft}^{3} / \mathrm{s}$. The area of sand and gravel that supplied this ground water contribution is $2.9 \mathrm{mi}^{2}$; thus, the average daily ground-water yield of the Schodack Terrace outwash gravel was calculated to be $1.2\left(\mathrm{ft}^{3} / \mathrm{s}\right) / \mathrm{mi}^{2}$, and the average daily ground-water yield from till was similarly calculated to be $0.52\left(\mathrm{ft}^{3} / \mathrm{s}\right) / \mathrm{mi}^{2}$. Joyce converted these average daily ground water yields to annual inches of precipitation per square mile and calculated that the ground-water discharge from (and by inference, the recharge to) the Schodack Terrace outwash sand and gravel was $16.3 \mathrm{in} / \mathrm{mi}^{2}$, while the similar value for upland till was $7.1 \mathrm{in} / \mathrm{mi}^{2}$. These figures are comparable to values calculated by Randall and others (1966, p. 66) for areas of till and stratified drift in the Quinnebaug River basin, in Connecticut.

\section{Aquifer Properties}

A series of exploratory test wells were drilled in selected areas of the Town of East Greenbush during 1959-60 as part of a general water-resources study conducted by a private consultant for the Town of East Greenbush to evaluate the potential for developing municipal wellfields. Aquifer tests were conducted at four sites, and all of the pumped wells were screened in confined ice-contact or deltaic sand and gravel. All of the pumped wells were either 8- or 12-in. in diameter and were pumped at rates ranging from 200 to more than $1050 \mathrm{gal} / \mathrm{min}$. Aquifer properties were estimated by the consultant through log-log (Theis) or semi-log analysis of drawdown and recovery data. A summary of aquifer properties and their values, as calculated by Myrick and Associates (1960), are given in Table 2.

All four of these aquifer-test sites are north of the recognizable Schodack terrace aquifer and are screened in ice-contact or deltaic sand and gravel deposits that occupy narrow preglacial bedrock channels (pl. 4). These buried ice-contact deposits, although localized, are highly transmissive. Average hydraulic conductivity at these four sites ranges from 430 to $2,360 \mathrm{ft} / \mathrm{d}$, with a mean of $1150 \mathrm{ft} / \mathrm{d}$ for the seven estimates shown in Table 2.

\section{Well Yields}

The reported yields of domestic and large-capacity production wells screened in deltaic and ice-contract sand and gravel deposits of the Schodack and Kinderhook terraces range widely. The yield of any well completed in sand and gravel is dependent on many factors, some of which are related to the physical properties of the aquifer, and some to the design of the well. Well-design factors include: (1) type of well construction, (2) amount of development, (3) screen length, (4) screen-slot size, (5) pump capacity, and (6) interference from nearby pumping wells. Aquifer-related factors include: (1) saturated thickness, (2) hydraulic conductivity, (3) storage coefficient, (4) amount and distribution of recharge to the aquifer, and (5) potential for induced infiltration from nearby surface-water bodies. Public-supply and industrial-supply wells obtain the largest yields from sand and gravel because they are typically of larger diameter (10-12 in.) than domestic wells and are screened for the maximum available yield. Domestic wells, by comparison, are typically 6-in. diameter and finished without screens; that is, open-ended, allowing water to enter only through the bottom. This factor, more than any other, severely limits the amount of water that such a well can produce. The yields of domestic wells finished in bedrock are much more variable than those finished in sand and gravel and are primarily dependent on the number and size of waterbearing fractures that the well bore intersects.

Reported well-yield data for 375 wells in the Schodack-Kinderhook area are summarized in Table 3. For comparative purposes, the study area was divided into halves, the northern half containing the Schodack Terrace aquifer, and the southern half containing the Kinderhook Terrace aquifer. The boundary between these two sections is arbitrarily placed along the $42^{\circ} 30^{\prime}$ latitude line.

Most of the domestic wells drilled in the Schodack-Kinderhook area are open-bore wells completed in bedrock and are typically 6-in. in diameter. As indicated in table 3, the average reported yield for 176 bedrock wells in the northern half of the study area is $7.5 \mathrm{gal} / \mathrm{min}$ (median, $5.25 \mathrm{gal} / \mathrm{min}$ ), and the average for 86 bedrock wells in the southern half is 
Table 2. Summary of aquifer tests in Rensselaer County, N.Y. (from Myrick and Associates, 1960).

[ft, feet; gal/min, gallons per minute; $\mathrm{ft} / \mathrm{d}$, feet per day, $\mathrm{ft}{ }^{2} / \mathrm{d}$, feet squared per day. Well locations are shown on plate 1.$]$

\begin{tabular}{|c|c|c|c|c|c|c|c|}
\hline \multicolumn{8}{|c|}{ A. Test Conditions (well and test data) } \\
\hline $\begin{array}{l}\text { Site name and } \\
\text { well number }\end{array}$ & $\begin{array}{l}\text { Well diameter } \\
\text { (inches) }\end{array}$ & $\begin{array}{l}\text { Well depth } \\
\text { (feet) }\end{array}$ & $\begin{array}{c}\text { Screened interval } \\
\text { (feet below land } \\
\text { surface) }\end{array}$ & $\begin{array}{l}\text { Test-pumping } \\
\text { rate } \\
\text { (gal/min) }\end{array}$ & $\begin{array}{l}\text { Test duration } \\
\text { (hours) }\end{array}$ & $\begin{array}{c}\text { Saturated } \\
\text { thickness of } \\
\text { aquifer (b) (ft)* }\end{array}$ & $\begin{array}{l}\text { Drawdown in } \\
\text { pumped well } \\
(\mathrm{ft})\end{array}$ \\
\hline \multicolumn{8}{|l|}{ Little League } \\
\hline Re-701 & 12 & 97 & $82-96$ & 610 & 100 & 28 & 34 \\
\hline \multicolumn{8}{|l|}{ Laraway } \\
\hline Re-791 & 8 & 81 & $70-80.5$ & 400 & 100 & 63 & 13 \\
\hline \multicolumn{8}{|l|}{ Witbeck no. 1} \\
\hline Re-811 & 12 & 105 & $90-105$ & 200 & 44 & 35 & 55 \\
\hline \multicolumn{8}{|l|}{ Witbeck no. 2} \\
\hline $\operatorname{Re}-1137$ & 8 & 87 & $73-87$ & 1050 & 100 & 74 & 15.7 \\
\hline
\end{tabular}

B. Test Results (hydraulic values for aquifer)

\begin{tabular}{|c|c|c|c|c|c|c|c|c|}
\hline \multirow[b]{2}{*}{$\begin{array}{l}\text { Site name and } \\
\text { well number }\end{array}$} & \multirow[b]{2}{*}{$\begin{array}{c}\text { Specific } \\
\text { capacity } \\
{[(\text { gal/min)/ft }]}\end{array}$} & \multicolumn{3}{|c|}{ Close observation well } & \multicolumn{3}{|c|}{ Distant observation well } & \multirow{2}{*}{$\begin{array}{c}\text { Mean } \\
\text { hydraulic } \\
\text { conductivity } \\
(K)(\mathrm{ft} / \mathrm{d})\end{array}$} \\
\hline & & $\begin{array}{c}\text { Transmissivity } \\
\left(T_{l}\right)(\mathrm{ft} / \mathrm{d})\end{array}$ & $\begin{array}{c}\text { Storage } \\
\text { coefficient } \\
\left(S_{I}\right)\end{array}$ & $\begin{array}{l}\text { Hydraulic } \\
\text { conductivity } \\
\left(K_{I}\right)(\mathrm{ft} / \mathrm{d})\end{array}$ & $\begin{array}{l}\text { Transmissivity } \\
\left(T_{2}\right)\left(\mathrm{ft}^{2} / \mathrm{d}\right)\end{array}$ & $\begin{array}{c}\text { Storage } \\
\text { coefficient } \\
\left(S_{2}\right)\end{array}$ & $\begin{array}{l}\text { Hydraulic } \\
\text { conductivity } \\
\left(K_{2}\right)(\mathrm{ft} / \mathrm{d})\end{array}$ & \\
\hline $\begin{array}{c}\text { Little League } \\
\text { Re-701 }\end{array}$ & 17.6 & $41,845^{\mathrm{a}}$ & $1.2 \times 10^{-11}$ & 1,494 & $200,534^{b}$ & $2.8 \times 10^{-3}$ & 3,234 & 2,364 \\
\hline $\begin{array}{c}\text { Laraway } \\
\text { Re-791 }\end{array}$ & 30.5 & $49,866^{\mathrm{c}}$ & $8.0 \times 10^{-3}$ & 791 & $51,470^{\mathrm{d}}$ & $1.8 \times 10^{-3}$ & 817 & 804 \\
\hline $\begin{array}{c}\text { Witbeck no. } 1 \\
\text { Re-811 }\end{array}$ & 3.6 & $\longrightarrow$ & $\longrightarrow$ & $\longrightarrow$ & $15,107^{\mathrm{e}}$ & $3.25 \times 10^{-4}$ & 432 & 432 \\
\hline $\begin{array}{c}\text { Witbeck no. } 2 \\
\text { Re-1137 }\end{array}$ & 66.9 & $61,898^{\mathrm{f}}$ & $1.2 \times 10^{-5}$ & 836 & $31,417^{\mathrm{g}}$ & $4.0 \times 10^{-3}$ & 424 & 630 \\
\hline
\end{tabular}

* at pumped well

a) from time-drawdown data, Re-774

e) from recovery data, $\mathrm{Re}-813$

b) from time-drawdown data, $\mathrm{Re}-807$

f) from time-drawdown data, Re-1138

c) from time-drawdown data, $\mathrm{Re}-792$

g) from time-drawdown data, Re-1139

d) from time-drawdown data, Re-794

essentially the same--7.2 gal/min (median, $5 \mathrm{gal} / \mathrm{min}$ ). Nearly all of these yield estimates are based on bail tests performed and reported by the driller.

Comparatively few domestic wells within the study area are finished in confined or unconfined sand and gravel; most of these are located on outwash or surface exposures of kame sand and gravel, and may be either large-diameter dug wells, small-diameter (2-in.) driven wells (well points) or most commonly, 6-in.-diameter drilled wells. Drilled wells completed in unconfined sand and gravel in the study area are typically less than $50 \mathrm{ft}$ deep and are completed open ended. Yields from domestic wells completed in unconfined sand and gravel in the northern half of the study area range from 4 to $50 \mathrm{gal} / \mathrm{min}$, with an average of $16 \mathrm{gal} / \mathrm{min}$ (median, $15 \mathrm{gal} / \mathrm{min}$ ), and yields from similarly completed domestic wells in the southern half of the study area range from 2 to $68 \mathrm{gal} / \mathrm{min}$, with an average of $18 \mathrm{gal} / \mathrm{min}$ (median, $15 \mathrm{gal} / \mathrm{min}$ ) (table 3).

In areas that lack a surficial sand and gravel aquifer, drillers have no choice but to drill deeper, possibly into bedrock, for a domestic supply. Several drillers in this area have obtained adequate domestic supplies from a thin, confined sand and gravel aquifer that extends westward and southwestward from the Schodack outwash terrace, and similarly westward and southwestward from the Kinderhook outwash terrace. These confined aquifers consist of either the coarse fractions of proximal bottomset beds of the prograding deltas that make up the Schodack and Kinderhook terraces, or coarse beds of subglacial fan deposits. The confined aquifer is commonly less than $5 \mathrm{ft}$ thick and is overlain by as much as $150 \mathrm{ft}$ of Lake Albany clay and silt. Most drilled domestic wells completed in this confined aquifer are finished without a screen (open ended), and water levels in these wells are commonly 
Table 3. Well yield, by water-use and aquifer type, for the Schodack-Kinderhook area, Rensselaer and Columbia Counties, N.Y.

[gal/min, gallons per minute]

\begin{tabular}{|c|c|c|c|c|c|}
\hline Well use/aquifer & $\begin{array}{l}\text { Number } \\
\text { of wells }\end{array}$ & $\begin{array}{l}\text { Range of } \\
\text { reported } \\
\text { yields } \\
\text { (gal/min) }\end{array}$ & $\begin{array}{l}\text { Mean } \\
\text { yield } \\
\text { (gal/min) }\end{array}$ & $\begin{array}{l}\text { Median } \\
\text { yield } \\
\text { (gal/min) }\end{array}$ & Remarks \\
\hline Domestic/bedrock & 176 & $0.1-60$ & 7.5 & 5.25 & Primarily 6-inch diameter wells. \\
\hline $\begin{array}{l}\text { Domestic/unconfined } \\
\text { sand \& gravel }\end{array}$ & 17 & $4.0-50$ & 16.1 & 15 & $\begin{array}{l}\text { Includes dug wells, driven wells, and } \\
6 \text {-inch unscreened observation } \\
\text { wells. }\end{array}$ \\
\hline $\begin{array}{l}\text { Domestic/confined } \\
\text { sand \& gravel }\end{array}$ & 20 & $1.0-80$ & 15.3 & 10 & $\begin{array}{l}\text { Includes } 6 \text {-inch unscreened obser- } \\
\text { vation wells. }\end{array}$ \\
\hline $\begin{array}{l}\text { Public supply/uncon- } \\
\text { fined sand \& gravel }\end{array}$ & 10 & $25-450$ & 173.1 & 120 & Well diameters from 8 to 12 inches. \\
\hline $\begin{array}{l}\text { Public supply/confined } \\
\text { sand \& gravel }\end{array}$ & 12 & $50-1050$ & 305.4 & 210 & Well diameters from 8 to 12 inches. \\
\hline Public supply/bedrock & 4 & $13-120$ & 52 & 37.5 & Well diameters from 6 to 12 inches. \\
\hline
\end{tabular}

\section{B. Southern half of study area (Kinderhook Terrace aquifer)}

\begin{tabular}{|c|c|c|c|c|c|}
\hline Well use/aquifer & $\begin{array}{l}\text { Number } \\
\text { of wells }\end{array}$ & $\begin{array}{l}\text { Range of } \\
\text { reported } \\
\text { yields } \\
\text { (gal//min) }\end{array}$ & $\begin{array}{l}\text { Mean } \\
\text { yield } \\
\text { (gal/min) }\end{array}$ & $\begin{array}{l}\text { Median } \\
\text { yield } \\
\text { (gal/min) }\end{array}$ & Remarks \\
\hline Domestic/bedrock & 86 & $0.7-427$ & 7.2 & 5 & Primarily 6-inch diameter wells. \\
\hline $\begin{array}{l}\text { Domestic/unconfined } \\
\text { sand \& gravel }\end{array}$ & 15 & $2.0-68$ & 18.3 & 15 & $\begin{array}{l}\text { Includes dug wells, driven wells, } \\
\text { and 6-inch unscreened observation } \\
\text { wells. }\end{array}$ \\
\hline $\begin{array}{l}\text { Domestic/confined } \\
\text { sand \& gravel }\end{array}$ & 18 & $1.0-30$ & 12.8 & 8.75 & $\begin{array}{l}\text { Includes } 6 \text {-inch unscreened obser- } \\
\text { vation wells. }\end{array}$ \\
\hline $\begin{array}{l}\text { Public supply/unconfined } \\
\text { sand \& gravel }\end{array}$ & 15 & $35-300$ & 104 & 100 & $\begin{array}{l}\text { Includes drilled wells of } 4.5 \text { to } 12 \\
\text { inches in diameter and dug wells up } \\
\text { to } 36 \text { inches in diameter. }\end{array}$ \\
\hline
\end{tabular}

at or above land surface during the spring. The average yield of 20 domestic wells finished in this confined aquifer in the northern half of the study area is $15 \mathrm{gal} / \mathrm{min}$ (median, $10 \mathrm{gal} / \mathrm{min}$ ), with a range in reported yields from 1 to $80 \mathrm{gal} / \mathrm{min}$ (table 3 ).

Similarly, the average yield of 18 domestic wells completed in the confined aquifer in the southern half of the study area is about $13 \mathrm{gal} / \mathrm{min}$ (median,
$8.75 \mathrm{gal} / \mathrm{min})$, with a range in reported yields from 1 to $30 \mathrm{gal} / \mathrm{min}$.

Several municipalities within the study area have installed high-capacity public-supply wells that are screened in either confined or unconfined sand and gravel aquifers. Some of the highest individual well yields obtained thus far have been from confined icecontact sand and gravel deposits that occupy bedrock 
channels in the southern part of the Town of East Greenbush. Four test wells ranging from 8 to $12 \mathrm{in.} \mathrm{in}$ diameter were test pumped at rates ranging from 200 to $1,050 \mathrm{gal} / \mathrm{min}$ in 1960 as part of a general waterresources study conducted by a private consultant for the Town of East Greenbush (table 2; Myrick and Associates, 1960). The average yield of 10 publicsupply wells finished in unconfined sand and gravel in the northern half of the study area was $173 \mathrm{gal} / \mathrm{min}$ (median, $120 \mathrm{gal} / \mathrm{min}$ ), and ranged from 25 to $450 \mathrm{gal} /$ min, whereas, the average yield of 12 public supply wells finished in confined sand and gravel in the same area was $305 \mathrm{gal} / \mathrm{min}$ (median, $210 \mathrm{gal} / \mathrm{min}$ ), and ranged from 50 to $1,050 \mathrm{gal} / \mathrm{min}$. This would seem to indicate that the confined sand and gravel aquifers in the study area are, for the most part, more transmissive than the overlying unconfined sand and gravel aquifer.

The southern half of the study area contains 15 high-capacity wells finished in the unconfined sand and gravel aquifer, most of which are supply wells or test wells for the villages of Valatie and Kinderhook. These wells are completed in coarse-grained recent alluvium and underlying outwash occupying the Kinderhook Creek valley and are under water-table (unconfined) conditions. These wells range from shallow dug wells of 36-in. diameter to drilled wells up to 12 in. in diameter, and the reported yields range from 35 to $300 \mathrm{gal} / \mathrm{min}$, with a mean of $104 \mathrm{gal} / \mathrm{min}$ (median, $100 \mathrm{gal} / \mathrm{min}$ ).

\section{Specific Capacity}

Another common measure of the relative yield of a production well is specific capacity $(Q / s)$, which is the ratio of the pumping rate $(Q)$ to drawdown $(s)$. Specific-capacity data can be used to estimate the transmissivity of an aquifer, and a high specific capacity generally indicates high aquifer transmissivity (Walton, p. 314, 1970). Specific capacity data are available for 16 wells (6 to 12 in. in diameter) that are finished in either confined or unconfined sand and gravel within the study area. Specific capacities (unadjusted for the effects of partial penetration) ranged from 0.55 (gal/min)/ft for a confined 6-in. domestic well finished in deltaic sand to $151(\mathrm{gal} / \mathrm{min}) / \mathrm{ft}$ for an 8-in. diameter supply well completed in unconfined kame and esker sand and gravel. Selected hydraulic characteristics obtained for these 16 wells are given in Table 4.

The estimates of transmissivity were made through a computer program (Bradbury and
Rothschild, 1985) that corrects for well loss and partial penetration, then solves the following equation for transmissivity $(T)$ in an iterative manner, using an initial estimate of $T$ :

$$
T=\frac{Q}{4 \pi\left(s-s_{w}\right)}\left[\ln \frac{2.25 T t}{r_{w}^{2} S}+2 s_{p}\right]
$$

where $T=$ transmissivity (feet squared per day)

$Q \quad=$ pumping rate (gallons per minute)

$s \quad=$ drawdown in pumped well (feet)

$s_{w} \quad=$ well loss (feet)

$t \quad=$ duration of pumping test (hours)

$r_{w} \quad=$ radius of well (inches)

$S \quad=$ storage coefficient (dimensionless)

$s_{p} \quad=$ partial penetration factor

The program then calculates an estimate of aquifer hydraulic conductivity from the calculated transmissivity and known saturated thickness. The calculated transmissivities for 16 wells screened in sand and gravel (table 4) range from 170 to $153,480 \mathrm{ft}^{2} / \mathrm{d}$, and estimated hydraulic conductivities range from 75 to $2,650 \mathrm{ft} / \mathrm{d}$. The mean transmissivity of these 16 wells is $31,090 \mathrm{ft}^{2} / \mathrm{d}$, and the mean hydraulic conductivity is $635 \mathrm{ft} / \mathrm{d}$. A comparison of the transmissivity values estimated from specific-capacity data for wells Re701, Re-791, Re-811, and Re-1137 (table 4) with those estimated from analysis of time-drawdown data (table 2) shows several large discrepancies--the values of $T$ estimated from time-drawdown analysis, with the exception of Re-1137 (table 2) are 2 to 10 times higher than corresponding $T$ values estimated from specificcapacity data (table 4). Similarly, estimates of hydraulic conductivity $(K)$ from time-drawdown data (table 2 ) are much higher than the corresponding values estimated from specific capacity (table 4). Bradbury and Rothschild (1985) note that, in general, estimates of $T$ from specific capacity are smaller than comparable $T$ values estimated from time-drawdown analysis but are typically of the same order of magnitude. The values of $T$ shown in table 4 appear to be more reasonable than those given in table 2 for the ice-contact, outwash, and deltaic sands and gravels in the study area. Moreover, the transmissivity and hydraulic conductivity estimates for these 16 wells (table 4) show a smaller range in values than those estimated from time-drawdown data obtained from observation wells at the four test sites (table 2). 


\section{Bedrock}

The bedrock underlying the SchodackKinderhook area consists primarily of sedimentary shales, sandstones, mudstones, and interbedded limestones, all of which are of Ordovician or Cambrian age. The bedrock in this area has been extensively folded, faulted, and thrusted-older Cambrian rock units to the east have been thrusted over younger Ordovician rocks to the west along a major fault line known as "Logans' Line", an overthrust fault that is a segment of a discontinuous overthrust line that extends from Canada through Vermont and New York into the southern Appalachian Mountains. It is named after Sir William Logan, former director of the Canadian Geological Survey, who first recognized its size and structural importance (Ruedemann, 1930, p. 143). In addition to faults, the bedrock units in this area were subjected to preglacial and glacial erosion, which created a network of broad drainage channels on the now-buried bedrock surface.

\section{Bedrock Surface Configuration}

The generalized topography of the buried bedrock surface in the Schodack-Kinderhook area is depicted on plate 4. This map was constructed from (1) surficial geologic map data showing areas of exposed bedrock at land surface, and (2) logs of wells stored in the USGS computerized GWSI well database. Most of the well data used to construct this map were collected during well inventories conducted in Columbia and Rensselaer Counties in the late 1940's, in conjunction with countywide ground-water studies (Arnow, 1951; Cushman, 1950). Other data were provided by Dr. Robert G. LaFleur of Rensselaer Polytechnic Institute, as part of a study of the hydrogeology of Town of Schodack (LaFleur, 1993). Plate 4 also shows the approximate locations of traces of major thrust and cross faults that transect the area (Elam, 1960; Fisher and others, 1970) and areas mapped as exposed bedrock (LaFleur, 1965, 1977a,b,c).

The configuration of the bedrock surface in the Schodack-Kinderhook area (pl. 4) is a result of tectonic activity, differential weathering, and preglacial and glacial erosion. The altitude of the bedrock surface in the mapped area ranges from $150 \mathrm{ft}$ below sea level in buried channels to approximately $750 \mathrm{ft}$ above sea level in the uplands, resulting in about $900 \mathrm{ft}$ of relief. Rock units that are resistant to weathering, such as conglomerates, cherts, sandstones, slates, and graywackes, form ridges and bedrock hills in the area. For example, Teller and Grandview Hills (near Sherwood Park), and Vandenburgh Hill (near Brookview), form a ridge along the eastern edge of the Hudson River gorge and consist of large "slide" blocks of resistant chert or limestone embedded in the otherwise easily erodible Snake Hill shale (Elam, 1960, p. 7). These "slide" blocks are large blocks of the older Mt. Merino Formation that were incorporated into the younger Snake Hill Shale during episodes of tectonic activity.

Faults and bedrock channels can be important hydrogeologic features in the development of groundwater supplies. Faults represent areas where the rock has been intensely fractured by tectonic forces, thereby increasing the secondary permeability of the rock (see next section). Bedrock channels may be filled, in part, with glaciodeltaic or ice-contact sand and gravel that can be used as productive aquifers, although they may not be really extensive (see sheet 2 ).

\section{Preglacial Drainage Channels}

Several major preglacial drainage channels in the bedrock surface are evident on plate 4 . In the northern half of the study area, a channel cut to about $50 \mathrm{ft}$ above sea level extends from the east side of Teller Hill (at Sherwood Park) south for about $4.5 \mathrm{mi}$ to Brookview, where it meets an east-west channel that was probably the path of the preglacial Moordener Kill. This east-west bedrock channel parallels the course of the present-day Moordener Kill and meets it at Castleton-on-Hudson.

South of Castleton-on-Hudson, another east-west trending channel extends southeastward for about $3 \mathrm{mi}$ from the confluence of the Muitzes Kill and the Hudson River. This channel is also cut down to about $50 \mathrm{ft}$ above sea level and may represent the northwestward-draining preglacial Muitzes Kill. A broad, sinuous channel in the southern part of the study area runs southwestward from North Chatham to Niverville, then turns south at Bishop Nelson Road to continue southward (just west of Kinderhook); this channel may be the course of the preglacial Valatie Kill-Kinderhook Creek drainage system.

In the southwestern corner of the mapped area, a deep, narrow channel curves around a bedrock ridge and is eroded down to altitudes as low as $155 \mathrm{ft}$ below sea level. Well Cb-157, east of the village of Stuyvesant, is completed in this channel and represents the greatest documented thickness $(275 \mathrm{ft})$ 
Table 4. Reported specific capacity, estimated transmissivity, and estimated hydraulic conductivity at selected wells in the Schodack-Kinderhook area, Rensselaer and Columbia Counties, N.Y.

[gal/min, gallons per minute; in., inch; (gal/min)/ft, gallons per minute per foot; $\mathrm{ft}^{2} / \mathrm{d}$, feet squared per day; $\mathrm{ft} / \mathrm{d}$, feet per day; ft, feet. Locations of wells shown on plate 1.]

\begin{tabular}{|c|c|c|c|c|c|c|c|c|c|c|c|c|}
\hline Well No. & Aquifer type & $\begin{array}{l}\text { Pumping } \\
\text { rate } \\
\text { (gal/min) }\end{array}$ & $\begin{array}{l}\text { Well } \\
\text { diameter } \\
\text { (in) }\end{array}$ & $\begin{array}{c}\text { Specific } \\
\text { capacity, } \\
\text { unadjusted } \\
\text { (gal/min)/ft }\end{array}$ & $\begin{array}{c}\text { Specific } \\
\text { capacity } \\
\text { adjusted } \\
(\text { gal/min)/ft }\end{array}$ & $\begin{array}{c}\text { Estimated } \\
\text { transmissivity } \\
\left(\mathrm{ft}^{2} / \mathrm{d}\right)\end{array}$ & $\begin{array}{c}\text { Estimated } \\
\text { hydraulic } \\
\text { conductivity } \\
\text { (ft/d) }\end{array}$ & $\begin{array}{c}\text { Saturated } \\
\text { thickness } \\
\text { of aquifer } \\
\text { (ft) }\end{array}$ & $\begin{array}{l}\text { Length of } \\
\text { screen } \\
\text { zone (ft) }\end{array}$ & $\begin{array}{l}\text { Storage } \\
\text { coefficient } \\
\text { used in } \\
\text { estimate }\end{array}$ & $\begin{array}{l}\text { Drawdown } \\
\text { in pumped } \\
\text { well (ft) }\end{array}$ & $\begin{array}{c}\text { Length of } \\
\text { test } \\
\text { (hours) }\end{array}$ \\
\hline $\operatorname{Re}-459$ & confined sand \& gravel & 135 & 8 & 7.94 & 7.98 & 2,450 & 120 & 20.5 & 20.5 & .0001 & 17 & 24 \\
\hline Re-1128 & confined sand \& gravel & 190 & 8 & 12.67 & 12.82 & 4,030 & 270 & 15 & 15 & .0001 & 15 & 24 \\
\hline Re-1129 & confined sand \& gravel & 275 & 8 & 14.86 & 15.17 & 4,800 & 130 & 36 & 36 & .0001 & 18.5 & 24 \\
\hline Re-1130 & confined sand \& gravel & 220 & 8 & 10.00 & 10.11 & 3,140 & 120 & 26 & 26 & .0001 & 22 & 24 \\
\hline Re-1131 & unconfined sand \& gravel & 407 & 10 & 19.54 & 20.35 & 11,770 & 235 & 50 & 10 & 0.20 & 20.82 & 72 \\
\hline Re-1137 & confined sand \& gravel & 1050 & 8 & 67.00 & 102.62 & 85,970 & 1,160 & 74 & 14 & .0001 & 15.7 & 96 \\
\hline Re-701 & confined sand \& gravel & 610 & 12 & 17.60 & 18.97 & 6,760 & 240 & 28 & 14 & .0028 & 34 & 100 \\
\hline Re-791 & confined sand \& gravel & 400 & 8 & 30.50 & 32.77 & 26,690 & 420 & 63 & 10.5 & .0018 & 13 & 100 \\
\hline Re-811 & confined sand \& gravel & 200 & 12 & 3.64 & 3.65 & 1,530 & 45 & 35 & 15 & .0003 & 55 & 44 \\
\hline Re-475 & unconfined sand \& gravel & 50 & 8 & 151.5 & 210 & 153,480 & 2,650 & 58 & 10 & 0.20 & 0.25 & 48 \\
\hline $\operatorname{Re}-703$ & confined sand \& gravel & 12 & 6 & 2.30 & 2.30 & 4,020 & 75 & 53 & 2.9 & .0001 & 5.21 & 1 \\
\hline Re-774 & confined sand \& gravel & 40 & 6 & 6.67 & 6.68 & 13,100 & 470 & 28 & $1 \dagger$ & .0001 & 6 & 1 \\
\hline Re-807 & confined sand \& gravel & 40 & 6 & 26.67 & 26.81 & 114,540 & 2,200 & 52 & $1 \dagger$ & .0001 & 1.5 & 1 \\
\hline Re-1049 & confined sand \& gravel & 7.5 & 6 & 0.55 & 0.55 & 170 & 30 & 6.5 & 3 & .0001 & 13.66 & 6 \\
\hline $\mathrm{Cb}-855$ & unconfined sand \& gravel & 110 & 6 & 73.3 & 76.4 & 46,900 & 1,470 & 32 & 6 & 0.20 & 1.5 & 8 \\
\hline $\mathrm{Cb}-856$ & unconfined sand \& gravel & 220 & 12 & 29.3 & 30.30 & 18,030 & 560 & 32 & 6 & 0.20 & 7.5 & 6 \\
\hline & & & & & Mean : & 31,090 & 635 & & & & & \\
\hline
\end{tabular}

* Adjusted for the effects of partial penetration

$\dagger$ well is finished open-ended; $1 \mathrm{ft}$ screened zone assumed. 
of stratified drift in Columbia County (Arnow, 1951, p. 14). This narrow channel may have been the path of the preglacial Stuyvesant Creek, but was more likely an alternative outlet of the Kinderhook-Valatie Creek drainage network to the Hudson River. This is supported by limited bedrock-surface altitude data from areas within the Hudson River gorge that indicate a narrow channel cut down to about $150 \mathrm{ft}$ below sea level (Dineen, 1977b,d).

\section{Faults}

The bedrock underlying the SchodackKinderhook area is divided into two structural provinces by a major thrust fault that runs north-south through the area, and which separates the younger, autochthonous, Ordovician shales of the Normanskill Formation, on the west, from the older, allocthonous, Cambrian rocks of the Bull and West Castleton Groups to the east. This fault is known as Logan's Line, and may represent the western edge of the Taconic Allocthon (klippe) (Elam, 1960, p. 111-112). Rock units on both sides of this fault plane display typical signs of old fault movement such as mylonite and fault breccia. Elam (1960) reported that rocks east of Logan's line show a well-developed fracture cleavage system, whereas rocks west of the line are cataclastically deformed, highly stratified, slickensided, and crushed (Elam, 1960, p. 139). Older deposits of fault breccia have now become brecciolas, a resistant rock resembling a conglomerate. A rare exposure of the Logan's Line fault plane (one of two in this area) is found where it crosses the Vierda Kill, northwest of Brookview, and shows the fault striking $\mathrm{N} 10^{\circ} \mathrm{E}$, and dipping $70^{\circ}{ }^{\circ}$ to the east (Elam, 1960, p. 98). Elam has mapped two subsidiary thrust faults in this area--the Rysdorph Fault, and the Ferry St. Fault (fig. 2b)--both of which have been overridden by the large thrust block of Cambrian rocks to the north of the northern cross fault, and are shown again in the center of the mapped area. The westward displacement of Logan's Line in the southern half of the mapped area implies the presence of a second tear fault (cross fault), shown here near the $42^{\circ} 30^{\prime}$ latitude line, thus delineating a much larger overthrust block of Cambrian rocks to the south (Fisher and others, 1970).

\section{Effects of Faults on Well Yields}

Joints and fracture traces in rock generally represent areas in which secondary permeability has been enhanced through fracturing. Wells drilled near extensive fracture zones can be expected to have greater yields than wells drilled into the same formation at some distance from these zones. The only exceptions are faults along which significant movement and, thus, rock disintegration, has occurred over geologic time. These crushed and decayed zones of faults typically contain a virtually impermeable mixture of pulverized rock flour (gouge) and coarser fragments (fault breccia) (van der Leedan, 1962, p. 59). Wells drilled directly into a fault zone tend to produce little or no water because the faults typically contain clayey rock flour (especially in shale or slate terrain), whereas wells drilled to either side of the fault would be likely to intercept "cleaner," jointed and broken rock and would thus be likely to have larger yields. A cursory examination of some reported bedrock well yields in the vicinity of the thrust faults in this area shows several wells that have yields considerably above the mean for the study area (table 3A). For example, well Re-803, a 6-in. diameter well with a $98-\mathrm{ft}$. rock wellbore, is reported to yield $60 \mathrm{gal} / \mathrm{min}$, and is about $500 \mathrm{ft}$ west of Logan's Line. Similarly, wells Re-1107 and Re-1108 have reported yields of 19 and $20 \mathrm{gal} / \mathrm{min}$, and are 300 and $500 \mathrm{ft}$ east of Logan's Line, respectively. Well, Re-1244, only $100 \mathrm{ft}$ west of Logan's Line, also has a reported yield of $19 \mathrm{gal} / \mathrm{min}$, and well Re-1101, about $100 \mathrm{ft}$ east of the Rysedorph Fault, has a reported yield of $15 \mathrm{gal} / \mathrm{min}$. In contrast, the mean of 176 reported well yields from 6-in domestic bedrock wells in the northern half of the study area is $7.5 \mathrm{gal} / \mathrm{min}$ (median, $5.25 \mathrm{gal} / \mathrm{min}$ ) (table 3A). Some wells near these fault zones have also been reported to have very low well yields, for example, well Re-461, which is $300 \mathrm{ft}$ west of the Ferry St. fault at Brookview, is $326 \mathrm{ft}$ deep ( $221 \mathrm{ft}$ of open bedrock borehole) and yielded only $0.1 \mathrm{gal} / \mathrm{min}$ when drilled and was subsequently abandoned.

\section{SUMMARY AND CONCLUSIONS}

Two glaciodeltaic outwash terraces in southern Rensselaer and northern Columbia counties known locally as the Schodack and Kinderhook Terraces, consist of ice-contact and outwash sand and gravel and together form a regional, unconfined, stratified drift aquifer with a combined area of $18.75 \mathrm{mi}^{2}$. The hydrogeology of these aquifers is summarized on four maps at 1:24,000 scale and depict (1) locations of 
wells and test holes, (2) surficial geology, (3) altitude of the water table, and (4) altitude of the bedrock surface. Hydrogeologic data indicate that both aquifers are associated with a thin, and probably discontinuous, confined aquifer that consists of glaciofluvial sand and gravel confined beneath thick deposits of lacustrine sand, silt, and clay.

Estimates of average hydraulic conductivity based on a consultant's aquifer tests conducted at four test wells screened in thicker sections of the confined aquifer, range from 430 to $2,360 \mathrm{ft} / \mathrm{d}$, with a mean of $1,150 \mathrm{ft} / \mathrm{d}$. The mean estimate of hydraulic conductivity derived from specific-capacity data from 16 test wells screened in confined and unconfined sections of the aquifers is $640 \mathrm{ft} / \mathrm{d}$.

Reported yields of domestic well completed in unconfined sections of the Schodack and Kinderhook Terrace aquifers average 16.1 and $18.3 \mathrm{gal} / \mathrm{min}$, respectively, and reported yields of domestic wells finished in the confined sections of these aquifers averaged 15.3 and $12.8 \mathrm{gal} / \mathrm{min}$, respectively. Yields from public-supply wells screened in the confined sections of the Schodack Terrace aquifer range from 50 to $1,050 \mathrm{gal} / \mathrm{min}$ and average $305 \mathrm{gal} / \mathrm{min}$.

Estimates of average annual recharge to the Schodack Terrace aquifer and adjacent upland till deposits, derived from a 1960 USGS study, were 16.3 and $7.1 \mathrm{in} / \mathrm{mi}^{2}$, respectively.

Two hydrogeologic sections through the Schodack and Kinderhook Terraces show that the eastern half of the Schodack Terrace is underlain, in most places, by a considerable thickness of ice-contact sand and gravel, whereas most of the Kinderhook Terrace is underlain by lacustrine sand, silt, and clay. This difference in underlying geologic structure produces greater, but more variable, saturated thicknesses of the unconfined aquifer in the Schodack Terrace than in the Kinderhook Terrace. In addition, the surficial outwash unit in the Schodack Terrace has a relatively large unsaturated zone (up to $60 \mathrm{ft}$ ), produced by the low base level of the Moordener Kill, which bisects the terrace and functions as a major ground water drain for the aquifer.

Bedrock that underlies the area has been highly modified through tectonic activity, differential weathering, and preglacial erosion to produce a surface with approximately $900 \mathrm{ft}$ of relief. A major thrust fault (Logan's Line) and several smaller subsidiary thrust and faults traverse the area in a north- south direction and appear to enhance the yield of bedrock wells drilled in their vicinity.

\section{SELECTED REFERENCES}

Arnow, Theodore, 1951, The ground-water resources of Columbia County, New York: New York State Department of Conservation Bulletin GW-25, 48 p.

Bradbury, K.R., and Rothschild, E.R., 1985, A computerized technique for estimating the hydraulic conductivity of aquifers from specific capacity data: Ground Water, v. 23, no. 2, pp. 240-246.

Capital District Regional Planning Commission, 1993, Groundwater/wellhead protection program-phase I, southwestern Rensselaer County: Schenectady, N.Y., Capital District Regional Planning Commission, 123 p.

Clough, Harbor, \& Associates, 1988, Comprehensive water supply plan for the Town of Schodack, Rensselaer County, New York: Albany, N.Y., Clough, Harbor, \& Associates, Engineers \& Planners, 250 p.

Cook, J.H., 1943, Glacial geology of the Coxsackie quadrangle, in Goldring, Winifred, Geology of the Coxsackie quadrangle, New York: New York State Museum Bulletin No. 332, p. 321-357.

Craddock, J.C., 1957, Stratigraphy and structure of the Kinderhook quadrangle: Geological Society of America Bulletin, v. 68, n. 6, p. 675-724.

Cushman, R.V., 1950, The ground-water resources of Rensselaer County, New York: New York State Department of Conservation Bulletin GW-21, 56 p.

Dale, T.N., 1904, Geology of the Hudson Valley between Hoosic and Kinderhook: U.S. Geological Survey Bulletin 242, $63 \mathrm{p}$.

DeSimone, D.J. and LaFleur, R.G., 1985, Glacial geology and history of the northern Hudson basin, New York and Vermont, in Lindermann, R.H. (ed.), New York State Geological Association 57th Annual Meeting Field Trip Guidebook: Saratoga Springs, N.Y., Skidmore College, p. 82-116.

DeSimone, D.J. and LaFleur, R.G., 1986, Glaciolacustrine phases in the northern Hudson lowland and correlation in western Vermont: Northeastern Geology, v. 8, p. 218-229.

Dineen, R.J., 1977a, Generalized bedrock surface map, Kinderhook, East Chatham, Stottville, and Chatham quadrangle: New York State Geological Survey OpenFile Report 2100.667, 1 sheet, 1:24,000 scale. , 1977b, Generalized bedrock surface map of part of the Kinderhook quadrangle: New York State Geological Survey Open-File Report 1p223, 1 sheet, 1:24,000 scale.

, 1977c, Generalized bedrock surface map, East Greenbush quadrangle: New York State Geological 
Survey Open-File Report 1p357, 1 sheet, 1:24,000 scale.

, 1977d, Generalized bedrock surface map of part of the Ravena quadrangle: New York State Geological Survey Open-File Report 1p355, 1 sheet, 1:24,000 scale.

-, 1986, Deglaciation of the Hudson valley between Hyde Park and Albany, N.Y., in Cadwell, D.H. (ed.), The Wisconsin stage of the First Geological District, Eastern New York: New York State Museum Bulletin 455, p. 89-108.

Dineen, R.J. and Rogers, W.B., 1979, Sedimentary environments in glacial Lake Albany in the Albany section of the Hudson-Champlain lowlands, in Friedman, G.M. (ed.), Joint annual meeting of the New York State Geological Association and New England Intercollegiate Geological Conference, Field Trip Guidebook: Troy, N.Y., Rensselaer Polytechnic Institute, p. 87-119.

Elam, J.G., 1960, Geology of the Troy South and East Greenbush quadrangles, New York: Troy, N.Y., Rensselaer Polytechnic Institute, unpublished Ph.D. thesis, $200 \mathrm{p}$.

LaFleur, R.G., 1961, Glacial features in the vicinity of Troy, N.Y., in LaFleur, R.G. (ed.), Guidebook to field trips, New York State Geological Association 33rd Annual Meeting: Troy, N.Y., Rensselaer Polytechnic Institute, p. A1-A21.

, 1963, Origin of sand and gravel deposits in New York: First Annual Sand and Gravel Symposium, Empire State Sand, Gravel and Road's-Mix Association.

, 1965a, Glacial geology of the Troy, N.Y. quadrangle: New York State Museum and Science Services Map and Chart Series, no. 7, 22 p

$\ldots, 1965 b$, Glacial lake sequences in the eastern Mohawk-northern Hudson region, in Hewitt, P.C. and Hall, L.M. (eds.), Guidebook to field trips, New York State Geological Association 37th Annual Meeting: Schenectady, N.Y., Union College, p. C1-C23. , 1977a, Surficial geologic map of the Kinderhook 7 1/2-minute quadrangle: open-file map, New York State
Geological Survey, Albany, N.Y., 1 sheet, 1:24,000 scale.

, 1977b, Surficial geologic map of part of the Delmar 7 1/2-minute quadrangle: open-file map, New York State Geological Survey, Albany, N.Y., 1 sheet, 1:24,000 scale.

, 1977c, Surficial geologic map of part of the Ravena 7 1/2-minute quadrangle: open-file map, New York State Geological Survey, Albany, N.Y., 1 sheet, 1:24,000 scale.

-, 1979, Deglacial events in the eastern Mohawknorthern Hudson lowland, in Friedman, G.M. (ed.), Joint annual meeting of the New York State Geological Association, and New England Intercollegiate Geological Conference, Field Trip Guidebook: Troy, N.Y., Rensselaer Polytechnic Institute, p. 326-350.

1993, Schodack aquifer hydrogeological report-underground injection control and wellhead protection demonstration project: Troy, N.Y., Rensselaer Polytechnic Institute, $104 \mathrm{p}$.

Myrick, G.C., and Associates, 1960, Report on water resources survey, Town of East Greenbush, Rensselaer County, New York: Albany, N.Y., George C. Myrick and Associates, $150 \mathrm{p}$.

Randall, A.D., and others, 1966, Water resources inventory of Connecticut-Part 1, Quinebaug River basin: Connecticut Water Resources Bulletin no. 8, 102 p.

Ruedemann, Rudolf, 1930, Geology of the Capital District: New York State Museum Bulletin no. 285, 218 p.

van der Leeden, Frits, 1962, The ground-water resources of Westchester County, New York: New York University, unpublished Masters thesis, $90 \mathrm{p}$.

Walton, W.C., 1970, Groundwater resource evaluation: New York, McGraw-Hill, 664 p.

Woodworth, J.B., 1905, Ancient water levels of the Champlain and Hudson valleys: New York State Museum Bulletin n. 84, 263 p. 


\title{
Appendix 1. Records of wells in the Schodack-Kinderhook area, Rensselaer and Columbia Counties, N.Y.
}

\author{
Explanation of Column Headings
}

Local well number:

Site Identifier:

Latitude:

Longitude:

Owner:

Altitude:

Primary use of water:

Date of construction:

Method of construction:

Diameter of casing:

Depth of well:

Source of depth data:
Local well numbers are assigned by the USGS to each well in the USGS Ground Water Site Inventory (GWSI) data base. County well numbers are sequential within each county, and wells within each county are identified by a two-letter county prefix. For example, wells within Rensselaer County are identified by the prefix "Re," and wells within Columbia County are identified by the prefix "Cb."

The Site Identifier is a unique 15-digit number that identifies each well within the GWSI database. It initially consists of the latitude and longitude of the well location, followed by a two-digit sequence number; subsequent revisions in latitude-longitude of any given well location are reflected in the latitude and longitude columns, and not in the Site Identifier. Multiple wells share essentially the same location (Site Identifier) and are distinguished by sequential sequence numbers (eg: 01, 02, 03).

The latitude of the well location in degrees, minutes, and seconds written together. The format used here is DDMMSS (degrees, minutes, seconds).

The longitude of the well location in degrees, minutes, and seconds written together. The format used here is DDDMMSS (degrees, minutes, seconds). Note that $73^{\circ}$ west longitude appears as "073" in this column.

The owner of the well at the time that the well was inventoried or the well information was obtained by the USGS. Some names are shortened or abbreviated.

The altitude of the land surface datum at each well, in feet above sea level. Land surface altitudes were estimated to the nearest foot from 1:24,000 scale topographic maps having a contour interval of $10 \mathrm{ft}$. Altitudes shown to the nearest tenth or hundredth of a foot were determined by spirit leveling by consulting engineers or USGS personnel.

The primary use of the water pumped from a site are as indicated by letter codes as follows:

C - Commercial (light industry, commercial establishments)

$\mathrm{H}$ - Domestic (individual residence)

I - Irrigation (for crops or orchards)

$\mathrm{N}$ - Industrial

P - Public supply (municipal supply wells)

S - Stock (primarily for watering livestock)

$\mathrm{T}$ - Institutional (schools, colleges, etc.)

U - Unused (water not used)

Represents exact date of well completion if known; otherwise the month and year, or simply year in which well was drilled. Format is MM-DD-YY (month, day, year).

Letter codes indicate the drilling method used to construct the well, as follows:

A - Air-rotary drilling - uses air to drill, drive casing, and remove cuttings

B - Bored or augered - generally with hollow-stem auger

C - Cable-tool drilling - also called "percussion drilling"

D - Dug well - generally stone curbed and of large diameter

$\mathrm{H}$ - Hydraulic rotary drilling - uses water to remove cuttings

$\mathrm{J}$ - Jetted - uses water to wash out the hole

P - Air-percussion drilling - a variation of air-rotary

$\mathrm{R}$ - Reverse-rotary drilling - a variation of hydraulic rotary

V - Driven well - commonly shallow "well points" of small diameter

W - Drive and wash method - also called "wash boring"

Nominal inside diameter of well casing or test hole (if no casing used), in inches. When more than two sizes of casing are used, the diameter of the upper section is listed first.

Depth of completed well, in feet below land surface. Where observation wells or production wells are installed in former test holes, depth refers to finished well depth. The hole depth in some wells may be greater than the well depth.

Letter codes indicate where the information about well depth was obtained, as follows:

D - From drillers' log or report

G - From private geologist, consultant, or university associate

L - Interpreted by USGS personnel from geophysical logs

$\mathrm{M}$ - Memory of the owner or driller

O - Reported by the owner of the well

$\mathrm{R}$ - Reported by a person other than the owner or driller

$S$ - Measured by USGS personnel 


\section{Explanation of Column Headings}

Bottom of casing:

Type of finish:

Aquifer code:

Lithology code:
Depth to bottom of casing, in feet below land surface. In open-ended wells, this is the total depth of the finished well. In bedrock wells, this depth may be the approximate depth to bedrock. In screened wells, this depth is less than the total depth of the finished well.

Letter codes indicate how the well is completed or the nature of the openings that admit water to the well, as follows:

C - porous concrete

F - gravel pack with perforated casing

$\mathrm{G}$ - gravel pack with screen

$\mathrm{H}$ - horizontal gallery

$\mathrm{O}$ - open-ended casing

$\mathrm{P}$ - perforated or slotted casing

$\mathrm{S}$ - well screen (in native formation)

$\mathrm{T}$ - sand point (drive point)

W - walled (dug wells) - using fieldstone, brick, tile, concrete blocks, or other material.

$\mathrm{X}$ - open hole in consolidated rock

An eight-character code that indicates the primary aquifer from which the well produces. Aquifer codes used in this study area include:

111ALVM - Postglacial alluvium occupying stream valleys.

112OTSH - Glacial outwash sand and gravel.

$112 \mathrm{ICNC}$ - Ice-contact deposits of predominantly sand and gravel including kames, kame terraces, kame deltas, and eskers.

112LAKE - Glaciolacustrine sediments of fine sand, silt, and clay deposited in glacial Lake Albany and its successive lake stages.

$112 \mathrm{GLCD}$ - Glaciodeltaic sediments of sand, gravel, and silt associated with the prograding outwash deltas of the Schodack and Kinderhook terraces. Includes proximal bottomset beds of outwash deltas and subglacial fan deposits, both of which form the thin confined aquifers associated with these two terraces.

112TILL - Deposits of till overlying bedrock.

377SCCK - Schodack Formation (Lower Cambrian) of Ruedemann (1930) described by Cushman (1950) as a greenish-gray, fine-grained, siliceous shale locally interbedded with a red grit, calcareous sandstone, a thinly bedded limestone, or a red and purple shale. Water reported as moderately hard with some iron.

377NSSU - Nassau Formation (Lower Cambrian) of Bird (1962), described by Cushman (1950) as a dark red and green soft shale, interbedded with quartzite and sandstone.

364NMKL - Normanskill Shale (Middle Ordovician) of Clarke (1903), described by Cushman (1950) as dark green to black argillaceous shale containing calcareous and chert beds. Water may contain hydrogen sulfide.

371TCSQ - Taconic Sequence rocks (upper Cambrian and lower Ordovician, undifferentiated) Indicates rock units that are considered part of the Taconic Allocthon. In the study area, this includes the Germantown Formation (shale, conglomerate, limestone); the Stuyvesant Falls Formation (shales, siltstones); the Mount Merino and Indian River Formations (shales, slates, cherts); and the Austin Glen Formation (graywackes, shale) (Fisher, 1970).

Letter codes that indicate the principal lithology of the primary aquifer listed (preceding column) encountered at the drillhole. Much of this information comes from drillers' logs. Lithology codes used in this study area are:

ALVM - Alluvium

CLSD - Clay, with some sand

GRVL - Gravel

LMSN - Limestone

SAND - Sand

SDCL - Sand and clay

SDGL - Sand and gravel

SDST - Sand and silt

SHLE - Shale

SLTE - Slate

TILL - Till 
Appendix 1. Records of wells in the Schodack-Kinderhook area, Rensselaer and Columbia

Counties, N.Y. (continued)

\section{Explanation of Column Headings}

Depth to top of aquifer (feet): Indicates the depth, in feet below land surface, to the top of the primary aquifer indicated under the column "Aquifer Code." A "zero" in this column indicates that the aquifer material appears at land surface.

Water level (feet):

Indicates the water level in the well, in feet below land surface, at the time that the well was inventoried. A minus sign (-) preceding the water level indicates a water level above land surface.

Date of water level measurement

Indicates exact date that the water level was measured, if known; otherwise month and year, or simply year. Format is MM-DD-YY.

Method water level measured:

Letter code indicates manner in which water level-data were obtained. Letter codes used are: E - Estimated

$\mathrm{R}$ - Reported, method not known. (Generally indicates water level reported by driller at time of drilling)

S - Steel tape measurement, generally by USGS personnel

$\mathrm{T}$ - Electric tape measurement, generally by USGS personnel.

Discharge (gallons per minute):

Contractor:

Remarks:
Indicates discharge (yield) of the well, in gallons per minute. Most yield data reported here for domestic wells are estimated from driller's bail tests. Discharge values for high-capacity test or supply wells are generally obtained during aquifer tests.

Name of the contractor who initially drilled the well. Some abbreviations are use; for example "Grmntn Artsn" or "Germantown" both indicate the Germantown Artesian Well Co.

Includes any miscellaneous data or information pertaining to the well. Abbreviations commonly used here include:

WL - Water level

GPD - gallons per day (gal/d)

rept. - reported

avg. - average

$\mathrm{H} 2 \mathrm{~S}$ - Hydrogen sulfide

Bull. GW-21 - Refers to New York State Dept. of Conservation Bulletin GW-21,

"The Ground-water resources of Rensselaer County, New York" by

R.V. Cushman

SWL - Static water level

PWL - Pumping water level

Shle - shale

Lmsn - limestone

DD - drawdown

$\mathrm{NO}^{3}$ as $\mathrm{N}$ - Total nitrate reported as nitrogen

$\mathrm{Cl}$ - Chloride

$\mathrm{mg} / \mathrm{L}$ - milligrams per liter

RCHD - Rensselaer County Health Dept.

grvl - gravel

LSD - land surface datum

QW - quality of water

$\mathrm{FeOH}$ - Iron oxide

S\&G - sand and gravel

Obs - observation

WSA - Water Supply Application (New York State)

NYSDOH - New York State Department of Health

Sta. - Station

Fm. - formation

in. - inches 
\% Appendix 1. Records of wells in the Schodack-Kinderhook area, Rensselaer and Columbia Counties, N.Y.

A. Wells north of $42^{\circ} 30^{\prime}$

\begin{tabular}{|c|c|c|c|c|c|c|c|c|c|c|c|c|c|}
\hline $\begin{array}{l}\text { Local } \\
\text { well } \\
\text { number }\end{array}$ & Site ID & $\begin{array}{c}\text { Latitude } \\
\text { (degrees) }\end{array}$ & $\begin{array}{l}\text { Longitude } \\
\text { (degrees) }\end{array}$ & Owner & $\begin{array}{c}\text { Altitude } \\
\text { of land } \\
\text { surface } \\
\text { (feet) }\end{array}$ & $\begin{array}{c}\text { Primary } \\
\text { use of } \\
\text { water }\end{array}$ & $\begin{array}{l}\text { Date of } \\
\text { con- } \\
\text { struction }\end{array}$ & $\begin{array}{l}\text { Method } \\
\text { con- } \\
\text { structed }\end{array}$ & $\begin{array}{l}\text { Diameter } \\
\text { of } \\
\text { casing } \\
\text { (in) }\end{array}$ & $\begin{array}{l}\text { Depth } \\
\text { of well } \\
\text { (feet) }\end{array}$ & $\begin{array}{c}\text { Source } \\
\text { of depth } \\
\text { data }\end{array}$ & $\begin{array}{l}\text { Bottom } \\
\text { of } \\
\text { casing } \\
\text { (feet) }\end{array}$ & $\begin{array}{l}\text { Type of } \\
\text { finish }\end{array}$ \\
\hline Re-408 & 423655073381602 & 423653 & 0733814 & Peterson, A. & 470 & $\mathrm{H}$ & $00-00-42$ & $\mathrm{C}$ & 6 & 150 & $\mathrm{D}$ & -- & $\mathrm{X}$ \\
\hline Re-409 & 423655073381601 & 423655 & 0733818 & Mowry, John E. & 480 & $\mathrm{H}$ & $00-00-41$ & $\mathrm{C}$ & 6 & 87 & $\mathrm{O}$ & 6 & - \\
\hline Re-411 & 423727073383401 & 423727 & 0733834 & Southworth, T. & 570 & $\mathrm{H}$ & $00-00-42$ & $\mathrm{C}$ & 8 & 80 & D & 17 & $\mathrm{X}$ \\
\hline Re-413 & 423708073390401 & 423708 & 0733904 & Powell, John & 485 & $\mathrm{H}$ & -- & $\mathrm{D}$ & 36 & 22 & $\mathrm{O}$ & 22 & - \\
\hline Re-429 & 423703073383501 & 423703 & 0733835 & Hotaling, B. & 505 & $\mathrm{H}$ & $00-00-32$ & $\mathrm{C}$ & 6 & 85 & $\mathrm{O}$ & 20 & $\mathrm{X}$ \\
\hline Re-442 & 423546073405201 & 423544 & 0734058 & Bastian, Joseph & 450 & $\mathrm{H}$ & -- & $\mathrm{C}$ & 6 & 64 & $\mathrm{D}$ & 20 & $\mathrm{X}$ \\
\hline Re-443 & 423503073410501 & 423503 & 0734105 & Fellows, Charles B. & 380 & $\mathrm{H}$ & -- & D & 24 & 10.3 & $\mathrm{O}$ & 10.3 & W \\
\hline Re-444 & 423605073403701 & 423605 & 0734037 & Miller, Alyda & 460 & $\mathrm{H}$ & $00-00-30$ & $\mathrm{C}$ & 6 & 101 & $\mathrm{O}$ & -- & $\mathrm{X}$ \\
\hline Re-445 & 423716073412601 & 423716 & 0734126 & Sager, Fred B. & 345 & $\mathrm{H}$ & -- & D & 42 & 25 & $\mathrm{O}$ & 25 & W \\
\hline Re-446 & 423612073424101 & 423612 & 0734241 & Gilligan, George & 235 & $\mathrm{H}$ & $00-00-28$ & $\mathrm{C}$ & 8 & 185 & $\mathrm{D}$ & -- & - \\
\hline Re-447 & 423614073424601 & 423614 & 0734246 & Shurttiff, John & 250 & $\mathrm{H}$ & $00-00-26$ & $\mathrm{C}$ & 6 & 70 & $\mathrm{D}$ & 18 & $\mathrm{X}$ \\
\hline Re-448 & 423701073420701 & 423635 & 0734221 & Onderkirk, Ervin & 280 & $\mathrm{H}$ & -- & $\mathrm{D}$ & 26 & 24 & $\mathrm{R}$ & 24 & $\mathrm{C}$ \\
\hline Re-449 & 423640073421601 & 423644 & 0734214 & Herberts, Martin & 285 & $\mathrm{H}$ & -- & $\mathrm{D}$ & 48 & 20 & $\mathrm{O}$ & 20 & W \\
\hline Re-450 & 423638073421001 & 423642 & 0734211 & Herrington, C.W. & 295 & $\mathrm{H}$ & -- & $\mathrm{C}$ & 6 & 180 & $\mathrm{R}$ & 30 & $\mathrm{X}$ \\
\hline $\operatorname{Re}-451$ & 423702073420801 & 423702 & 0734208 & Rieck, H. & 310 & $\mathrm{H}$ & -- & $\mathrm{C}$ & 6 & 149 & $\mathrm{O}$ & 149 & $\mathrm{O}$ \\
\hline Re-452 & 423713073420401 & 423713 & 0734209 & Neale, Charles & 320 & $\mathrm{H}$ & $00-00-33$ & $\mathrm{C}$ & 8 & 145 & $\mathrm{~S}$ & 34 & $\mathrm{X}$ \\
\hline Re-456 & 423638073433401 & 423638 & 0734339 & W. Onderdonk Estate & 290 & $\mathrm{H}$ & $09-12-25$ & $\mathrm{C}$ & 6 & 131 & $\mathrm{D}$ & 85 & $\mathrm{X}$ \\
\hline Re-458 & 423219073440501 & 423217 & 0734402 & Peter, Charles & 215 & $\mathrm{H}$ & $00-00-31$ & $\mathrm{C}$ & 6 & 103 & $\mathrm{R}$ & 6 & $\mathrm{X}$ \\
\hline Re-459 & 423218073444601 & 423218 & 0734441 & Fort Orange Paper Co. & 15 & $\mathrm{U}$ & -- & $\mathrm{C}$ & 12 & 97 & $\mathrm{O}$ & 26 & $\mathrm{~F}$ \\
\hline Re-460 & 423227073432001 & 423227 & 0734316 & Cooper, Charles J. & 220 & $\mathrm{H}$ & $00-00-46$ & $\mathrm{D}$ & 24 & 18 & $\mathrm{O}$ & 18 & W \\
\hline Re-461 & 423237073430901 & 423237 & 0734306 & Brookview School & 240 & $\mathrm{U}$ & $00-00-18$ & $\mathrm{C}$ & 6 & 326 & $\mathrm{D}$ & 105 & $\mathrm{X}$ \\
\hline Re-462 & 423051073422101 & 423051 & 0734221 & Lansing, M.T. & 275 & $\mathrm{H}$ & $05-25-15$ & $\mathrm{C}$ & 6 & 96 & $\mathrm{D}$ & 11 & $\mathrm{X}$ \\
\hline Re-463 & 423045073422101 & 423045 & 0734221 & Masten, Sarah D. & 275 & $\mathrm{H}$ & $05-29-15$ & $\mathrm{C}$ & 6 & 150 & $\mathrm{D}$ & 90 & $\mathrm{X}$ \\
\hline
\end{tabular}


Appendix 1. Records of wells in the Schodack-Kinderhook area, Rensselaer and Columbia Counties, N.Y.

A. Wells north of $42^{\circ} 30^{\prime}$.

\begin{tabular}{|c|c|c|c|c|c|c|c|c|c|}
\hline $\begin{array}{c}\text { Local well } \\
\text { number }\end{array}$ & $\begin{array}{l}\text { Aquifer } \\
\text { code }\end{array}$ & $\begin{array}{l}\text { Lithology } \\
\text { code }\end{array}$ & $\begin{array}{l}\text { Depth } \\
\text { to top } \\
\text { (feet) }\end{array}$ & $\begin{array}{l}\text { Water } \\
\text { level } \\
\text { (feet) }\end{array}$ & $\begin{array}{c}\text { Date water } \\
\text { level } \\
\text { measured }\end{array}$ & $\begin{array}{c}\text { Method } \\
\text { water level } \\
\text { measured }\end{array}$ & $\begin{array}{l}\text { Discharge } \\
\text { (gpm) }\end{array}$ & Contractor & Remarks \\
\hline Re-408 & 377SCCK & SHLE & 3 & 8 & $00-00-42$ & -- & 2.5 & Jensen, R. & Soft water reported \\
\hline Re-409 & 377SCCK & SHLE & 6 & 4 & $00-00-41$ & -- & 5 & Jensen, R. & Water very soft \\
\hline Re-411 & $377 \mathrm{SCCK}$ & SHLE & 17 & 28 & $00-00-42$ & $\mathrm{E}$ & 3 & Hall \& Co. & Very hard water reported \\
\hline $\operatorname{Re}-413$ & 371TCSQ & SHLE & -- & -- & -- & - & -- & -- & WL $18 \mathrm{ft}, 50 \mathrm{gpd}$ \\
\hline Re-429 & 377SCCK & SHLE & 20 & 10 & $00-00-32$ & $\mathrm{R}$ & 6 & Koons & Hard water reported \\
\hline Re-442 & 377SCCK & SHLE & 20 & -- & -- & - & 2.6 & McQueen & Soft water reported \\
\hline Re-443 & 112OTSH & GRVL & 0 & 3.1 & $04-00-46$ & $\mathrm{~S}$ & -- & -- & $150 \mathrm{gpd}$, soft water reported \\
\hline Re-444 & $377 \mathrm{NSSU}$ & SHLE & 12 & 18 & $00-00-30$ & $\mathrm{R}$ & -- & Kornetzki & $150 \mathrm{gpd}$, hard water reported \\
\hline Re-445 & $112 \mathrm{ICNC}$ & SDGL & 0 & 12 & 04-00-46 & $\mathrm{R}$ & -- & -- & Hard water reported \\
\hline Re-446 & $377 \mathrm{SCCK}$ & SHLE & -- & 100 & $00-00-28$ & - & -- & Stewart Bros. & 200 gpd, hard water reported \\
\hline $\mathrm{Re}-447$ & 377SCCK & SHLE & 18 & 18 & $00-00-26$ & $\mathrm{R}$ & .25 & Grmntn Artsn & Avg pumpage 100 gpd w \\
\hline Re-448 & 112LAKE & SAND & 0 & -- & -- & - & -- & -- & $\mathrm{WL} 21 \mathrm{ft}, 250 \mathrm{gpd}$, soft \\
\hline Re-449 & 112LAKE & SAND & 0 & -- & -- & - & -- & -- & WL $17 \mathrm{ft}$, hard water reported \\
\hline $\operatorname{Re}-450$ & 377SCCK & SHLE & 30 & 35 & $04-00-46$ & - & -- & Kornetzki & $\mathrm{H} 2 \mathrm{~S}$ reported, $150 \mathrm{gpd}$, soft water \\
\hline $\operatorname{Re}-451$ & 112OTSH & SAND & 0 & -- & -- & - & 5.0 & Shortsleeves & -- \\
\hline Re-452 & 377SCCK & SHLE & 34 & 17 & $00-00-33$ & $\mathrm{~S}$ & 20 & Grmntn Artsn & Soft water, Driller reports yield of $20 \mathrm{gpm}$ \\
\hline $\operatorname{Re}-456$ & 364NMKL & SHLE & 85 & 76 & $09-12-25$ & $\mathrm{~S}$ & 2 & Grmntn Artsn & Hard water reported \\
\hline $\mathrm{Re}-458$ & 364NMKL & SHLE & 6 & 13 & $00-00-31$ & $\mathrm{R}$ & 7.5 & McQueen, J. & Moderate hardness and $\mathrm{H} 2 \mathrm{~S}$ reported \\
\hline Re-459 & 112GLCD & SDGL & 26 & 6 & $05-16-46$ & $\mathrm{R}$ & 135 & Hall \& Co. & Well abandoned due to high iron \\
\hline Re-460 & 112OTSH & SAND & 15 & 12.5 & $05-16-46$ & $\mathrm{R}$ & 4 & -- & Hardpan $11-15 \mathrm{ft}$, black sand $15-18 \mathrm{ft}$ \\
\hline Re-461 & 364NMKL & SHLE & 105 & 63 & $00-00-18$ & $\mathrm{R}$ & .10 & Grmntn Artsn & Strong H2S odor, poor yield; well abandoned \\
\hline Re-462 & 377SCCK & SHLE & -- & 36 & $05-25-15$ & $\mathrm{R}$ & 1.0 & McQueen & Very hard water reported \\
\hline Re-463 & 377SCCK & SHLE & -- & -- & -- & - & -- & McQueen & Tastes of kerosene \\
\hline
\end{tabular}


$\approx$ Appendix 1. Records of wells in the Schodack-Kinderhook area, Rensselaer and Columbia Counties, N.Y. A. Wells north of $42^{\circ} 30^{\prime}$

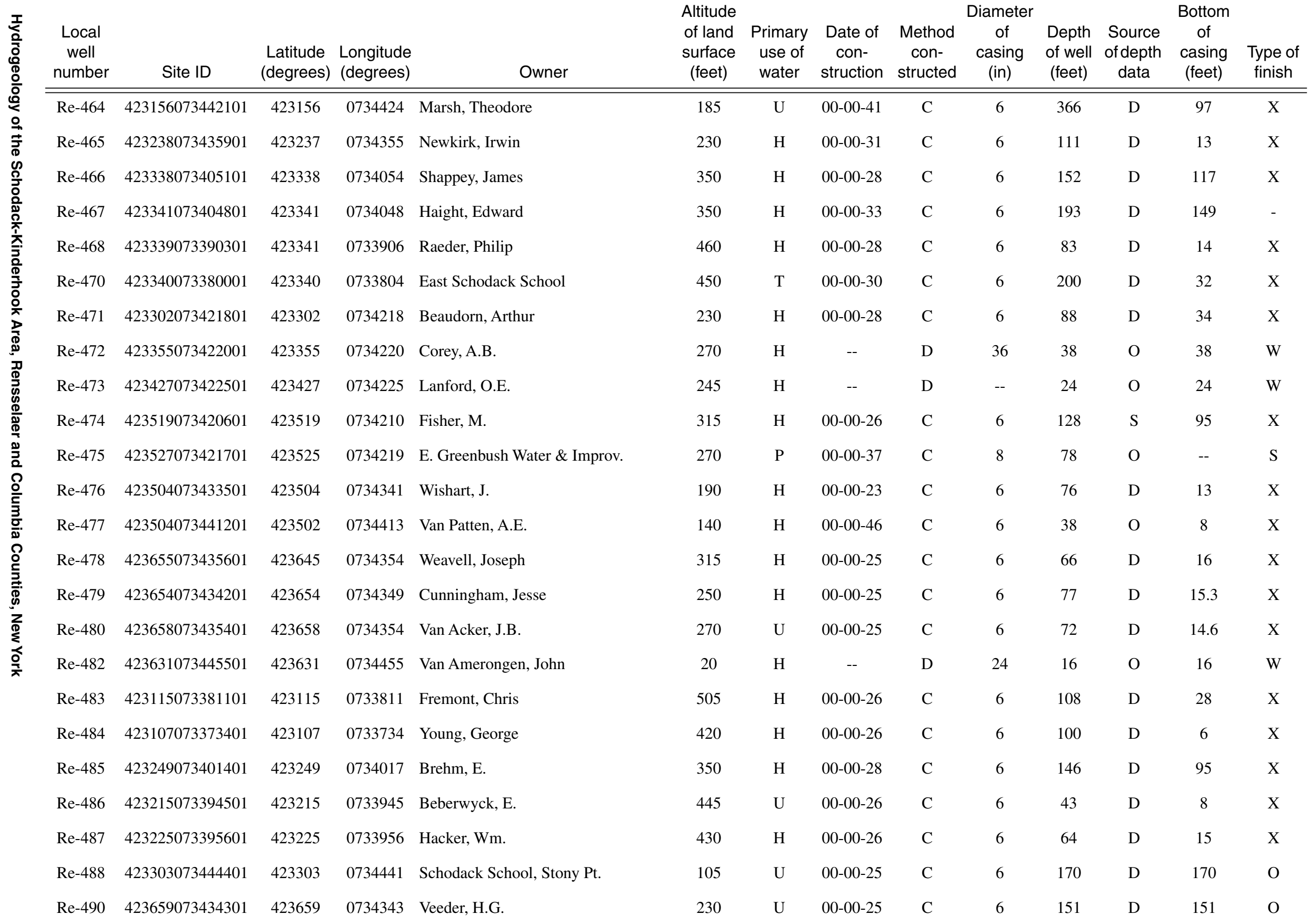


Appendix 1. Records of wells in the Schodack-Kinderhook area, Rensselaer and Columbia Counties, N.Y.

A. Wells north of $42^{\circ} 30^{\prime}$.

\begin{tabular}{|c|c|c|c|c|c|c|c|c|c|}
\hline $\begin{array}{l}\text { Local well } \\
\text { number }\end{array}$ & $\begin{array}{l}\text { Aquifer } \\
\text { code }\end{array}$ & $\begin{array}{l}\text { Lithology } \\
\text { code }\end{array}$ & $\begin{array}{l}\text { Depth } \\
\text { to top } \\
\text { (feet) }\end{array}$ & $\begin{array}{l}\text { Water } \\
\text { level } \\
\text { (feet) }\end{array}$ & $\begin{array}{c}\text { Date water } \\
\text { level } \\
\text { measured }\end{array}$ & $\begin{array}{c}\text { Method } \\
\text { water level } \\
\text { measured }\end{array}$ & $\begin{array}{l}\text { Discharge } \\
\text { (gpm) }\end{array}$ & Contractor & Remarks \\
\hline $\operatorname{Re}-464$ & 364NMKL & SHLE & -- & -- & $00-00-41$ & - & -- & Goold, G. & Dry well, abandoned \\
\hline Re-465 & 364NMKL & SHLE & 13 & 9 & $00-00-31$ & $\mathrm{R}$ & 1.5 & Grmntn Artsn & -- \\
\hline Re-466 & 377SCCK & SHLE & 117 & 35 & $00-00-28$ & $\mathrm{R}$ & .75 & Grmntn Artsn & Well later deepened to $200 \mathrm{ft}, \mathrm{H} 2 \mathrm{~S}$ reported \\
\hline Re-467 & 377SCCK & SHLE & 149 & 37 & $00-00-33$ & $\mathrm{R}$ & -- & Hall \& Co. & Well probably destroyed by Thruway exit ramp \\
\hline Re-468 & 377SCCK & SHLE & 14 & 10 & $00-00-28$ & $\mathrm{R}$ & 4 & Grmntn Artsn & Bailer tested on completion at $4 \mathrm{gpm}$ \\
\hline Re-470 & 377SCCK & SHLE & 32 & 21 & $00-00-30$ & $\mathrm{~S}$ & 2.5 & Grmntn Artsn & Bailer test yield $2.5 \mathrm{gpm}$ with PWL at $93 \mathrm{ft}$ \\
\hline Re-471 & 377SCCK & SHLE & 34 & 30 & $00-00-28$ & $\mathrm{R}$ & -- & Germantown & Soft water reported \\
\hline $\operatorname{Re}-472$ & 112GLCD & GRVL & 0 & 37 & $05-00-46$ & $\mathrm{~S}$ & -- & -- & Abandoned dug well of same depth nearby \\
\hline Re-473 & $112 \mathrm{GLCD}$ & SDGL & 0 & 16 & $12-00-54$ & $\mathrm{R}$ & -- & -- & -- \\
\hline Re-474 & 377SCCK & SHLE & 95 & 53 & $00-00-26$ & $\mathrm{~S}$ & 1.5 & Grmntn Artsn & -- \\
\hline $\mathrm{Re}-475$ & $112 \mathrm{ICNC}$ & SDGL & 8 & 20 & $00-00-37$ & $\mathrm{R}$ & 50 & Shaver, Wm. & Re- 810 also at this location \\
\hline Re-476 & 364NMKL & SHLE & 13 & 20 & $00-00-23$ & $\mathrm{R}$ & 1 & Grmntn Artsn & Owner reports $\mathrm{H} 2 \mathrm{~S}$ Bailed at $1 \mathrm{gpm}$ \\
\hline Re-477 & 364NMKL & SHLE & 8 & -- & -- & - & .25 & Fick Bros & Analysis shows iron. Bailed at $15 \mathrm{GPH}$ \\
\hline Re-478 & 364NMKL & SHLE & 16 & 16 & $00-00-25$ & $S$ & .5 & Germantown & Hard water reported, well in cemetery \\
\hline $\operatorname{Re}-479$ & 364NMKL & SHLE & 15.3 & 15 & $00-00-25$ & $\mathrm{~S}$ & 1 & Grmntn Artsn & Water table at rock surface \\
\hline Re-480 & 364NMKL & SHLE & 14.6 & 12 & $00-00-25$ & $\mathrm{~S}$ & -- & Germantown & Well contaminated from nearby cesspool \\
\hline Re-482 & 111ALVM & SDGL & 0 & -- & -- & - & -- & -- & WL $11 \mathrm{ft}$ reported \\
\hline Re-483 & 377SCCK & SHLE & 28 & 9 & $00-00-26$ & - & 1.5 & Grmntn Artsn & -- \\
\hline Re-484 & $377 \mathrm{SCCK}$ & SHLE & 6 & 18 & $00-00-26$ & $\mathrm{R}$ & .5 & Grmntn Artsn & Moderate hardness reported \\
\hline Re-485 & 377SCCK & SHLE & 95 & 23 & $00-00-28$ & $\mathrm{R}$ & .5 & Grmntn Artsn & Moderate hardness reported \\
\hline Re-486 & 377SCCK & SHLE & 8 & 18 & $00-00-26$ & $\mathrm{R}$ & 1.5 & Germantown & Abandoned-contaminated from surface drainage \\
\hline Re-487 & 377SCCK & SHLE & 15 & 15 & $00-00-26$ & $\mathrm{R}$ & 10 & Grmntn Artsn & 1 gpm @ 21 ft, 3 gpm @ 28 ft, 10 gpm @ 50 ft \\
\hline Re-488 & 112LAKE & SAND & -- & 145 & $00-00-25$ & $\mathrm{~S}$ & -- & Grmntn Artsn & Well abandoned because of poor yield \\
\hline Re-490 & 112GLCD & SAND & 151 & 51 & $00-00-25$ & $\mathrm{~S}$ & 1 & Grmntn Artsn & Well ends in black sand; not used \\
\hline
\end{tabular}


Ш Appendix 1. Records of wells in the Schodack-Kinderhook area, Rensselaer and Columbia Counties, N.Y. A. Wells north of $42^{\circ} 30^{\prime}$

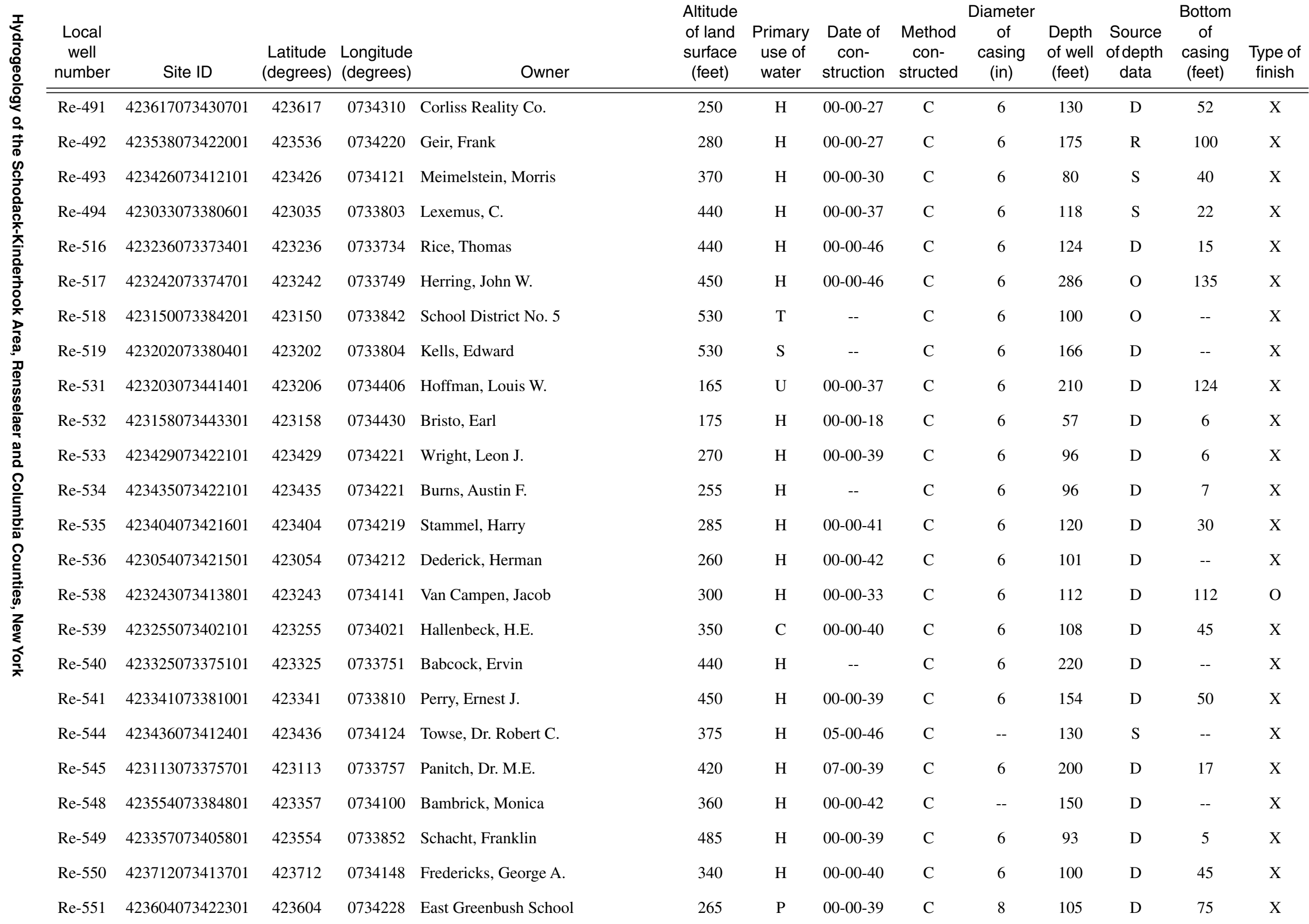


Appendix 1. Records of wells in the Schodack-Kinderhook area, Rensselaer and Columbia Counties, N.Y.

A. Wells north of $42^{\circ} 30^{\prime}$.

\begin{tabular}{|c|c|c|c|c|c|c|c|c|c|}
\hline $\begin{array}{l}\text { Local well } \\
\text { number }\end{array}$ & $\begin{array}{l}\text { Aquifer } \\
\text { code }\end{array}$ & $\begin{array}{l}\text { Lithology } \\
\text { code }\end{array}$ & $\begin{array}{l}\text { Depth } \\
\text { to top } \\
\text { (feet) }\end{array}$ & $\begin{array}{l}\text { Water } \\
\text { level } \\
\text { (feet) }\end{array}$ & $\begin{array}{c}\text { Date water } \\
\text { level } \\
\text { measured }\end{array}$ & $\begin{array}{c}\text { Method } \\
\text { water level } \\
\text { measured }\end{array}$ & $\begin{array}{l}\text { Discharge } \\
\text { (gpm) }\end{array}$ & Contractor & Remarks \\
\hline $\operatorname{Re}-491$ & 364NMKL & SHLE & 52 & 26 & $00-00-27$ & $\mathrm{~S}$ & 7 & Grmntn Artsn & Fine sand over bedrock \\
\hline Re-492 & 377SCCK & SHLE & 100 & 66 & $00-00-27$ & $\mathrm{R}$ & -- & -- & Bailed at $4 \mathrm{gpm}$ on completion \\
\hline Re-493 & 377SCCK & SHLE & 40 & 14 & $00-00-30$ & $\mathrm{R}$ & 10 & Germantown & Bailing at $10 \mathrm{gpm}$ did not produce any DD \\
\hline Re-494 & 377SCCK & SHLE & 22 & 0 & $05-22-46$ & - & 5 & -- & Water level at LSD, sometimes flows, very hard \\
\hline Re-516 & 377SCCK & SHLE & 15 & 17 & $00-00-46$ & $\mathrm{R}$ & 4 & Gardenier, L. & -- \\
\hline Re-517 & 377SCCK & SHLE & 135 & 18 & $05-24-46$ & $\mathrm{~S}$ & 1.5 & Gardenier, L. & -- \\
\hline Re-518 & 377SCCK & SHLE & -- & -- & -- & - & -- & Shortsleeves & Soft water reported \\
\hline Re-519 & 377SCCK & SHLE & 0 & -- & -- & - & -- & Shortsleeves & Second 90-ft well supplies residence \\
\hline Re-531 & 364NMKL & SHLE & 124 & -- & -- & - & -- & Hall \& Co. & Well abandoned, no water, $30-\mathrm{ft}$ dug well used \\
\hline Re-532 & 364NMKL & SHLE & 6 & 22 & $00-00-18$ & $\mathrm{R}$ & 4 & Grmntn Artsn & Moderate hardness reported \\
\hline Re-533 & 377SCCK & SHLE & 6 & 13 & 00-00-39 & $\mathrm{R}$ & 4.5 & Hall \& Co. & Very hard water reported \\
\hline Re-534 & 377SCCK & SHLE & 7 & -- & -- & - & -- & Hall \& Co. & WL $13 \mathrm{ft}, 3 \mathrm{gpm}$ \\
\hline Re-535 & 377SCCK & SHLE & 30 & 13 & $00-00-41$ & $\mathrm{R}$ & 6 & Hall \& Co. & -- \\
\hline Re-536 & 377SCCK & SHLE & 3 & 30 & $00-00-42$ & $\mathrm{R}$ & 4 & Hall \& Co. & 0-3 Soil, 3-22 Shle, 22-63 Lmsn, 63-101 Shle \\
\hline Re-538 & 112OTSH & GRVL & 0 & 40 & $00-00-33$ & $\mathrm{R}$ & 2 & Hall \& Co. & Very hard water reptd, gravel 0-112 ft \\
\hline Re-539 & 377SCCK & SLTE & 45 & 22 & $00-00-40$ & $\mathrm{R}$ & 3 & Hall \& Co. & Serves roadside diner \\
\hline Re-540 & 377SCCK & LMSN & -- & -- & -- & - & -- & Hall \& Co. & $300 \mathrm{gpd}$, hard, well deepened from 151 to 220 \\
\hline Re-541 & 377SCCK & SHLE & 50 & 29 & 00-00-39 & $\mathrm{R}$ & 1.25 & Hall \& Co. & Softwater, 1/3 gpm @ $115 \mathrm{ft}, 1 \mathrm{gpm} @ 135 \mathrm{ft}$ \\
\hline Re-544 & $377 \mathrm{SCCK}$ & SHLE & -- & 20 & $05-00-46$ & $\mathrm{~S}$ & -- & Hall \& Co. & -- \\
\hline Re-545 & 377SCCK & SHLE & 17 & 4 & 07-00-39 & $\mathrm{R}$ & 2 & Stewart Bros & -- \\
\hline Re-548 & 377SCCK & SLTE & 0 & 9 & $00-00-42$ & $\mathrm{R}$ & 3 & Hall \& Co. & Hard water reported, bedrock at land surface \\
\hline Re-549 & 377SCCK & SLTE & 5 & 14 & 00-00-39 & $\mathrm{R}$ & 15 & Hall \& Co. & Very hard water reported \\
\hline Re-550 & 377SCCK & SHLE & 45 & 12 & $00-00-40$ & $\mathrm{R}$ & 2.5 & Hall \& Co. & Hard water reported \\
\hline Re-551 & 377SCCK & SLTE & 75 & 35 & 00-0039 & $\mathrm{E}$ & 17 & Hall \& Co. & -- \\
\hline
\end{tabular}


$\underset{N}{\omega}$ Appendix 1. Records of wells in the Schodack-Kinderhook area, Rensselaer and Columbia Counties, N.Y. A. Wells north of $42^{\circ} 30^{\prime}$

\begin{tabular}{|c|c|c|c|c|c|c|c|c|c|c|c|c|c|}
\hline $\begin{array}{c}\text { Local } \\
\text { well } \\
\text { number }\end{array}$ & Site ID & $\begin{array}{l}\text { Latitude } \\
\text { (degrees) }\end{array}$ & $\begin{array}{l}\text { Longitude } \\
\text { (degrees) }\end{array}$ & Owner & $\begin{array}{c}\text { Altitude } \\
\text { of land } \\
\text { surface } \\
\text { (feet) }\end{array}$ & $\begin{array}{c}\text { Primary } \\
\text { use of } \\
\text { water }\end{array}$ & $\begin{array}{c}\text { Date of } \\
\text { con- } \\
\text { struction }\end{array}$ & $\begin{array}{l}\text { Method } \\
\text { con- } \\
\text { structed }\end{array}$ & $\begin{array}{l}\text { Diameter } \\
\text { of } \\
\text { casing } \\
\text { (in) }\end{array}$ & $\begin{array}{l}\text { Depth } \\
\text { of well } \\
\text { (feet) }\end{array}$ & $\begin{array}{c}\text { Source } \\
\text { of depth } \\
\text { data }\end{array}$ & $\begin{array}{l}\text { Bottom } \\
\text { of } \\
\text { casing } \\
\text { (feet) }\end{array}$ & $\begin{array}{l}\text { Type of } \\
\text { finish }\end{array}$ \\
\hline Re-552 & 423518073420801 & 423518 & 0734208 & East Greenbush School Dist. 3 & 342 & $\mathrm{~T}$ & $00-00-15$ & $\mathrm{C}$ & 6 & 82 & $\mathrm{D}$ & 14 & $\mathrm{X}$ \\
\hline Re-553 & 423438073422101 & 423438 & 0734224 & Andrews, D.B. & 250 & $\mathrm{H}$ & $00-00-37$ & $\mathrm{C}$ & 6 & 103 & $\mathrm{D}$ & 70 & $\mathrm{X}$ \\
\hline Re-554 & 423456073413601 & 423456 & 0734136 & Kettyle, Robert & 370 & $\mathrm{H}$ & $00-00-33$ & $\mathrm{C}$ & -- & 120 & $\mathrm{D}$ & -- & $X$ \\
\hline Re-555 & 423442073412701 & 423442 & 0734127 & Hans, William & 330 & $\mathrm{H}$ & $00-00-47$ & $\mathrm{C}$ & 6 & 45 & $\mathrm{O}$ & 3 & $\mathrm{X}$ \\
\hline Re-556 & 423444073405301 & 423444 & 0734058 & Zimmerman, Roy & 360 & $\mathrm{H}$ & 00-00-39 & $\mathrm{C}$ & 6 & 45 & $\mathrm{D}$ & 45 & $\mathrm{O}$ \\
\hline Re-557 & 423432073412101 & 423432 & 0734121 & Brodbeck, Elizabeth & 370 & $\mathrm{H}$ & $00-00-34$ & $\mathrm{C}$ & 6 & 104 & $\mathrm{D}$ & 22 & $\mathrm{X}$ \\
\hline Re-558 & 423430073412101 & 423430 & 0734121 & Brodbeck, Elizabeth & 370 & $\mathrm{H}$ & $00-00-32$ & $\mathrm{C}$ & 6 & 100 & $\mathrm{D}$ & 16 & $X$ \\
\hline Re-559 & 423432073411801 & 423427 & 0734118 & Henniger, Elmer F. & 355 & $\mathrm{H}$ & $00-00-40$ & $\mathrm{C}$ & 6 & 140 & $\mathrm{D}$ & 14 & $X$ \\
\hline Re-560 & 423520073414901 & 423520 & 0734149 & Roads, Mrs. Orange & 355 & $\mathrm{H}$ & $00-00-33$ & $\mathrm{C}$ & 6 & 75 & $\mathrm{D}$ & 14 & $\mathrm{X}$ \\
\hline $\operatorname{Re}-561$ & 423513073415101 & 423506 & 0734157 & Galer, Deforest I. & 350 & $\mathrm{H}$ & $00-00-40$ & $\mathrm{C}$ & 6 & 220 & $\mathrm{D}$ & 45 & $X$ \\
\hline Re-562 & 423513073415401 & 423457 & 0734144 & Eldredge, Donald & 360 & $\mathrm{H}$ & 00-00-39 & $\mathrm{C}$ & 6 & 76 & $\mathrm{D}$ & 20 & $\mathrm{X}$ \\
\hline Re-563 & 423510073415001 & 423500 & 0734147 & Van Schaick, Francis A. & 360 & $\mathrm{H}$ & $00-00-40$ & $\mathrm{C}$ & 6 & 98 & $\mathrm{D}$ & 29 & $X$ \\
\hline Re-564 & 423459073414601 & 423459 & 0734146 & Aldrich, Donald & 360 & $\mathrm{H}$ & 00-00-39 & $\mathrm{C}$ & 6 & 89 & $\mathrm{D}$ & 25 & $X$ \\
\hline Re-565 & 423122073391301 & 423122 & 0733913 & Mead, Prescott Jr. & 490 & $\mathrm{H}$ & $00-00-43$ & $\mathrm{C}$ & 6 & 114 & $\mathrm{D}$ & 14 & $\mathrm{X}$ \\
\hline Re-598 & 423136073431101 & 423134 & 0734306 & Friend, Elizabeth & 245 & $\mathrm{H}$ & $09-00-44$ & $\mathrm{C}$ & 8 & 145 & $\mathrm{D}$ & 64 & $X$ \\
\hline Re-623 & 423015073460001 & 423015 & 0734553 & Comingo, John & 30 & $\mathrm{U}$ & $00-00-25$ & $\mathrm{C}$ & 6 & 232 & $\mathrm{D}$ & 70 & $X$ \\
\hline Re-627 & 423630073403401 & 423032 & 0734034 & Recker, Robert & 330 & $\mathrm{H}$ & $00-00-46$ & $\mathrm{C}$ & 6 & 130 & $\mathrm{D}$ & 30 & $X$ \\
\hline Re-628 & 423116073405601 & 423116 & 0734056 & Sheehy, Frank & 310 & $\mathrm{C}$ & -- & $\mathrm{C}$ & 6 & 90 & $\mathrm{D}$ & 75 & $\mathrm{X}$ \\
\hline Re-633 & 423209073423601 & 423209 & 0734236 & Goold, Bertha & 290 & $\mathrm{H}$ & $00-00-11$ & $\mathrm{C}$ & 6 & 115 & $\mathrm{D}$ & 115 & $\mathrm{O}$ \\
\hline Re-634 & 423102073444601 & 423102 & 0734440 & Morgan, Michael J. & 170 & $\mathrm{H}$ & $09-12-21$ & $\mathrm{C}$ & 6 & 130 & $\mathrm{D}$ & 98 & $\mathrm{X}$ \\
\hline Re-641 & 423313073444201 & 423313 & 0734442 & Vandewall, Wm. & 30 & $\mathrm{H}$ & -- & $\mathrm{D}$ & -- & 20 & $\mathrm{O}$ & -- & W \\
\hline Re-642 & 423332073443901 & 423332 & 0734439 & Becker, John & 95 & $\mathrm{H}$ & -- & $\mathrm{C}$ & -- & 300 & $\mathrm{O}$ & -- & $\mathrm{X}$ \\
\hline Re-646 & 423457073380501 & 423436 & 0733808 & Steinberg, Sam & 570 & $S$ & -- & $\mathrm{C}$ & 6 & 180 & $\mathrm{O}$ & 10 & $\mathrm{X}$ \\
\hline Re-647 & 423447073382901 & 423447 & 0733829 & Lout, G. & 575 & $\mathrm{H}$ & -- & $\mathrm{D}$ & -- & 20 & $\mathrm{O}$ & 20 & W \\
\hline
\end{tabular}


Appendix 1. Records of wells in the Schodack-Kinderhook area, Rensselaer and Columbia Counties, N.Y.

A. Wells north of $42^{\circ} 30^{\prime}$.

\begin{tabular}{|c|c|c|c|c|c|c|c|c|c|}
\hline $\begin{array}{l}\text { Local well } \\
\text { number }\end{array}$ & $\begin{array}{l}\text { Aquifer } \\
\text { code }\end{array}$ & $\begin{array}{l}\text { Lithology } \\
\text { code }\end{array}$ & $\begin{array}{l}\text { Depth } \\
\text { to top } \\
\text { (feet) }\end{array}$ & $\begin{array}{l}\text { Water } \\
\text { level } \\
\text { (feet) }\end{array}$ & $\begin{array}{c}\text { Date water } \\
\text { level } \\
\text { measured }\end{array}$ & $\begin{array}{c}\text { Method } \\
\text { water level } \\
\text { measured }\end{array}$ & $\begin{array}{l}\text { Discharge } \\
\text { (gpm) }\end{array}$ & Contractor & Remarks \\
\hline Re-552 & 377SCCK & SHLE & 14 & -- & -- & - & -- & Germantown & Site now used as Community Bldg. \\
\hline Re-553 & 377SCCK & SHLE & 70 & 28 & $00-00-37$ & $\mathrm{R}$ & 3 & Hall \& Co. & Soft water reported \\
\hline Re-554 & 377SCCK & SLTE & 0 & 18 & $00-00-33$ & $\mathrm{R}$ & 10 & Hall \& Co. & Existing well deepened from 78 to $120 \mathrm{ft}$ \\
\hline Re-555 & 377SCCK & SHLE & 3 & -- & -- & - & -- & -- & QW analysis in Bulletin GW-21 \\
\hline Re-556 & 112OTSH & SDGL & 0 & 19 & 00-00-39 & $\mathrm{R}$ & 5 & Hall \& Co. & Hard water, iron reported \\
\hline Re-557 & 377SCCK & SHLE & 22 & 22 & $00-00-34$ & $\mathrm{R}$ & 2.5 & Hall \& Co. & Very hard water reported \\
\hline Re-558 & 377SCCK & SLTE & 16 & 20 & $00-00-32$ & $\mathrm{R}$ & 3.5 & Hall \& Co. & -- \\
\hline Re-559 & $377 \mathrm{SCCK}$ & SHLE & 14 & 25 & $00-00-40$ & $\mathrm{R}$ & 2 & Hall \& Co. & Hard water reported \\
\hline Re-560 & 377SCCK & SLTE & 14 & -- & -- & - & 7 & Hall \& Co. & Soft water reported \\
\hline Re-561 & 377SCCK & SHLE & 45 & 47 & $00-00-40$ & $\mathrm{R}$ & 1.5 & Hall \& Co. & Moderate hardness reported \\
\hline Re-562 & $377 \mathrm{SCCK}$ & SHLE & 20 & -- & -- & - & -- & Hall \& Co. & $3 \mathrm{gpm}$, hardwater reported \\
\hline Re-563 & 377SCCK & SHLE & 29 & 13 & $00-00-40$ & $\mathrm{E}$ & 5 & Hall \& Co. & -- \\
\hline Re-564 & 377SCCK & SHLE & 25 & 21 & 00-00-39 & $\mathrm{R}$ & 5 & Hall \& Co. & -- \\
\hline Re-565 & 377SCCK & SHLE & 14 & 11 & $00-00-43$ & $\mathrm{R}$ & 10 & Hall \& Co. & Very hard water reported \\
\hline Re-598 & 364NMKL & SHLE & 64 & 25 & 09-00-44 & $\mathrm{R}$ & 3 & Stewart Bros. & Drillers log: 0-64 till, $64-145$ shale \\
\hline Re-623 & 364NMKL & SHLE & 70 & -- & $11-25-46$ & - & 0 & Grmntn Artsn & Dry, well abandoned \\
\hline Re-627 & 377SCCK & SHLE & 30 & -- & -- & - & 3.5 & Shaver & QW analysis in Bulletin GW-21, Table 6 \\
\hline Re-628 & 377SCCK & SHLE & 75 & 20 & $11-26-46$ & $\mathrm{R}$ & 13 & Jensen & Soft water reported \\
\hline Re-633 & 112OTSH & SDGL & 0 & -- & -- & - & -- & McQueen & Log ends at $88 \mathrm{ft}$, well depth uncertain \\
\hline Re-634 & 364NMKL & SHLE & 97 & 90 & $09-12-21$ & $\mathrm{R}$ & 4 & McQueen & Driller: blue clay, sand, gravel 0-97 ft \\
\hline Re-641 & 112TILL & TILL & -- & 15 & $11-26-46$ & $\mathrm{R}$ & -- & -- & Very hard water reported \\
\hline Re-642 & 364NMKL & SHLE & -- & 80 & $11-26-46$ & $\mathrm{R}$ & -- & -- & $\mathrm{H} 2 \mathrm{~S}$ reported \\
\hline Re-646 & 377SCCK & SHLE & 10 & -- & -- & - & -- & Jensen, R. & Soft water, could not reduce DD by bailing \\
\hline Re-647 & 377SCCK & SHLE & 0 & 14 & $11-00-46$ & $\mathrm{R}$ & -- & -- & Very soft water reported \\
\hline
\end{tabular}


W Appendix 1. Records of wells in the Schodack-Kinderhook area, Rensselaer and Columbia Counties, N.Y. A. Wells north of $42^{\circ} 30^{\prime}$

\begin{tabular}{|c|c|c|c|c|c|c|c|c|c|c|c|c|c|}
\hline $\begin{array}{c}\text { Local } \\
\text { well } \\
\text { number }\end{array}$ & Site ID & $\begin{array}{l}\text { Latitude } \\
\text { (degrees) }\end{array}$ & $\begin{array}{l}\text { Longitude } \\
\text { (degrees) }\end{array}$ & Owner & $\begin{array}{c}\text { Altitude } \\
\text { of land } \\
\text { surface } \\
\text { (feet) }\end{array}$ & $\begin{array}{c}\text { Primary } \\
\text { use of } \\
\text { water }\end{array}$ & $\begin{array}{c}\text { Date of } \\
\text { con- } \\
\text { struction }\end{array}$ & $\begin{array}{l}\text { Method } \\
\text { con- } \\
\text { structed }\end{array}$ & $\begin{array}{l}\text { Diameter } \\
\text { of } \\
\text { casing } \\
\text { (in) }\end{array}$ & $\begin{array}{l}\text { Depth } \\
\text { of well } \\
\text { (feet) }\end{array}$ & $\begin{array}{c}\text { Source } \\
\text { of depth } \\
\text { data }\end{array}$ & $\begin{array}{c}\text { Bottom } \\
\text { of } \\
\text { casing } \\
\text { (feet) }\end{array}$ & $\begin{array}{c}\text { Type of } \\
\text { finish }\end{array}$ \\
\hline Re-649 & 423344073380501 & 423344 & 0733805 & Auer, Thomas & 460 & $\mathrm{H}$ & -- & $\mathrm{C}$ & 6 & 132 & $\mathrm{O}$ & 27 & $X$ \\
\hline Re-660 & 423706073392301 & 423711 & 0733923 & Hardgrove, Edward & 450 & $\mathrm{U}$ & $00-00-00$ & $\mathrm{D}$ & 48 & 15 & $\mathrm{O}$ & 15 & $\mathrm{~W}$ \\
\hline Re-664 & 423222073404201 & 423222 & 0734042 & Rose, Frank & 350 & $\mathrm{H}$ & $00-00-32$ & $\mathrm{C}$ & 6 & 90 & $\mathrm{D}$ & 23 & $X$ \\
\hline Re-701 & 423532073423701 & 423532 & 0734237 & East Greenbush-Little League Site & 261.87 & $\mathrm{U}$ & $05-00-59$ & $\mathrm{C}$ & 12 & 95.5 & $\mathrm{~S}$ & 82.0 & $S$ \\
\hline Re-702 & 423225073430501 & 423225 & 0734305 & U.S. Geological Survey & 175 & $\mathrm{U}$ & $10-21-65$ & B & 2.50 & 16.3 & $\mathrm{~S}$ & 13.3 & $\mathrm{~T}$ \\
\hline Re-703 & 423534073423401 & 423534 & 0734234 & U.S. Geological Survey & 275 & $\mathrm{U}$ & $10-14-82$ & A & 6 & 80.0 & G & 79.6 & $S$ \\
\hline Re-710 & 423052073415401 & 423052 & 0734154 & Knickerbocker, Wm. & 260 & $\mathrm{H}$ & -- & $\mathrm{C}$ & 4 & 46 & $\mathrm{~S}$ & 25 & $\mathrm{X}$ \\
\hline Re-711 & 423137073405201 & 423137 & 0734052 & Wernig, J. Sr. & 310 & $\mathrm{U}$ & -- & $\mathrm{D}$ & 18 & 21.5 & $\mathrm{~S}$ & 22 & W \\
\hline Re-712 & 423127073410001 & 423127 & 0734100 & Davis, Charles H., Sr. & 290 & $\mathrm{H}$ & $00-00-56$ & $\mathrm{D}$ & 36 & 13.7 & $\mathrm{~S}$ & 13.7 & - \\
\hline Re-713 & 423131073412801 & 423131 & 0734128 & Champane, W. & 290 & $\mathrm{H}$ & -- & $\mathrm{C}$ & 4 & 69.6 & $\mathrm{~S}$ & 69.6 & $\mathrm{O}$ \\
\hline Re-714 & 423157073424601 & 423157 & 0734246 & Haggerty, Robert & 240 & $\mathrm{H}$ & -- & $\mathrm{D}$ & -- & 3.05 & $\mathrm{~S}$ & 3.05 & W \\
\hline Re-715 & 423137073430001 & 423137 & 0734300 & Morgen, W. K. & 240 & $\mathrm{H}$ & -- & $\mathrm{C}$ & 6 & 80.3 & $S$ & 31.0 & $X$ \\
\hline Re-716 & 423132073423301 & 423132 & 0734233 & Cantine, Walt & 250 & $\mathrm{H}$ & -- & $\mathrm{C}$ & 6 & 95.1 & $\mathrm{~S}$ & 95.1 & $\mathrm{O}$ \\
\hline Re-717 & 423117073423101 & 423117 & 0734231 & Tomko, Wasco & 250 & $\mathrm{H}$ & -- & $\mathrm{D}$ & 12 & 12 & $\mathrm{~S}$ & 11.8 & $\mathrm{O}$ \\
\hline $\operatorname{Re}-718$ & 423108073424401 & 423108 & 0734244 & Walsh, Mrs. C. & 245 & $\mathrm{H}$ & -- & $\mathrm{D}$ & 36 & 9.6 & $\mathrm{~S}$ & 9.6 & W \\
\hline Re-719 & 423241073403201 & 423241 & 0734032 & Payne, Floyd & 350 & $\mathrm{H}$ & $00-00-40$ & $\mathrm{C}$ & 6 & 71.2 & $\mathrm{~S}$ & -- & $\mathrm{X}$ \\
\hline Re-720 & 423218073405201 & 423218 & 0734052 & Hogle, J. & 345 & $\mathrm{H}$ & $00-00-58$ & $\mathrm{C}$ & -- & 165 & $S$ & -- & $X$ \\
\hline $\operatorname{Re}-721$ & 423211073404601 & 423211 & 0734046 & Frazee, William & 340 & $\mathrm{H}$ & -- & $\mathrm{D}$ & 42 & 12.7 & $\mathrm{~S}$ & 12.7 & W \\
\hline $\operatorname{Re}-722$ & 423251073401601 & 423251 & 0734016 & Beverwick, Mr. E. & 350 & $\mathrm{H}$ & -- & $\mathrm{C}$ & 6 & 197 & $\mathrm{R}$ & -- & $\mathrm{X}$ \\
\hline Re-723 & 423259073411601 & 423259 & 0734116 & Van Kampen, Jacob & 260 & $\mathrm{~S}$ & -- & $\mathrm{D}$ & 30 & 10.1 & $\mathrm{R}$ & 10.1 & $\mathrm{O}$ \\
\hline Re-724 & 423258073423601 & 423258 & 0734236 & Roney, Mr. L. & 275 & $\mathrm{H}$ & $04-29-60$ & $\mathrm{C}$ & 4 & 89.9 & $\mathrm{~S}$ & 87 & $X$ \\
\hline Re-725 & 423258073423401 & 423258 & 0734234 & Bohus, Joseph & 280 & $\mathrm{H}$ & -- & $\mathrm{C}$ & 4 & 89.3 & $S$ & -- & $\mathrm{X}$ \\
\hline Re-726 & 423212073425001 & 423212 & 0734250 & Bolt, Mr. N. & 250 & $\mathrm{H}$ & -- & $\mathrm{D}$ & 36 & 13.5 & $\mathrm{~S}$ & 13.5 & W \\
\hline Re-727 & 423207073424101 & 423207 & 0734241 & Rogers, Mr. Lewis & 270 & $\mathrm{H}$ & $01-01-52$ & $\mathrm{C}$ & 6 & 218 & $\mathrm{R}$ & -- & $\mathrm{X}$ \\
\hline
\end{tabular}


Appendix 1. Records of wells in the Schodack-Kinderhook area, Rensselaer and Columbia Counties, N.Y.

A. Wells north of $42^{\circ} 30^{\prime}$.

\begin{tabular}{|c|c|c|c|c|c|c|c|c|c|}
\hline $\begin{array}{l}\text { Local well } \\
\text { number }\end{array}$ & $\begin{array}{l}\text { Aquifer } \\
\text { code }\end{array}$ & $\begin{array}{l}\text { Lithology } \\
\text { code }\end{array}$ & $\begin{array}{l}\text { Depth } \\
\text { to top } \\
\text { (feet) }\end{array}$ & $\begin{array}{l}\text { Water } \\
\text { level } \\
\text { (feet) }\end{array}$ & $\begin{array}{c}\text { Date water } \\
\text { level } \\
\text { measured }\end{array}$ & $\begin{array}{c}\text { Method } \\
\text { water level } \\
\text { measured }\end{array}$ & $\begin{array}{l}\text { Discharge } \\
\text { (gpm) }\end{array}$ & Contractor & Remarks \\
\hline Re-649 & 377SCCK & SHLE & 27 & -- & -- & - & 10 & Goold Bros. & SWL is $26 \mathrm{ft}$, well bailed at $5 \mathrm{gpm}$ at $90 \mathrm{ft}$ \\
\hline Re-660 & $112 \mathrm{ICNC}$ & SDGL & 0 & -- & -- & - & -- & -- & USGS observation well \\
\hline Re-664 & 377SCCK & SLTE & 23 & -- & -- & - & 4 & Hall \& Co. & -- \\
\hline Re-701 & $112 \mathrm{ICNC}$ & SDGL & 70 & 21.9 & $04-17-60$ & $\mathrm{~S}$ & 610 & Hall \& Co. & Test well, aquifer test data in Myrick Rept \\
\hline Re-702 & 112LAKE & SAND & 8 & 3.56 & $12-09--65$ & $\mathrm{~S}$ & - & USGS & Discontinued as observation well $9 / 84$ \\
\hline Re-703 & 112SDGV & SDGL & 17 & 45.3 & $10-14-82$ & $\mathrm{~S}$ & 12 & Ferraioli & QW sample taken during test pumping \\
\hline Re-710 & 377SCCK & SHLE & 25 & 11.7 & $09-07-60$ & $\mathrm{~S}$ & -- & Shaver & Tenant reports hard water, metallic taste \\
\hline $\operatorname{Re}-711$ & $112 \mathrm{ICNC}$ & SDGL & 0 & 15.9 & $07-13-60$ & $\mathrm{~S}$ & -- & -- & Nearby drilled well used for water-no info \\
\hline Re-712 & 112OTSH & SDGL & -- & 3.20 & $07-13-60$ & $\mathrm{~S}$ & -- & -- & Must boil water before drinking-owner \\
\hline Re-713 & 112OTSH & GRVL & 0 & 19.6 & 08-04-60 & $\mathrm{S}$ & -- & Shaver & -- \\
\hline $\operatorname{Re}-714$ & 112LAKE & SDST & 0 & .65 & 08-09-60 & $\mathrm{S}$ & -- & -- & -- \\
\hline Re-715 & 377SCCK & SHLE & 26 & 24.4 & $08-09-60$ & $\mathrm{~S}$ & -- & Shaver & -- \\
\hline Re-716 & 112GLCD & GRVL & 0 & 15.6 & $08-09-60$ & $\mathrm{~S}$ & -- & Seaburger & Well bailed at more than $30 \mathrm{gpm}$ when drilled \\
\hline Re-717 & 112LAKE & SAND & 3 & 8.03 & $09-08-60$ & $\mathrm{~S}$ & -- & -- & Owner reports can pump dry at 2-3 gpm \\
\hline Re-718 & 112LAKE & SDGL & 0 & 6.53 & 09-08-60 & $\mathrm{S}$ & -- & -- & -- \\
\hline Re-719 & 377SCCK & SHLE & 11.4 & 16.2 & $07-01-60$ & $S$ & -- & Shaver & Well drilled in abandoned dug well \\
\hline Re-720 & 377SCCK & SHLE & 0 & 44.2 & $07-01-60$ & $\mathrm{~S}$ & -- & Shortsleeves & -- \\
\hline Re-721 & 112OTSH & SDGL & .0 & 8.84 & $08-16-60$ & $\mathrm{~S}$ & -- & -- & Bedrock at $13 \mathrm{ft}$ \\
\hline Re-722 & $377 \mathrm{SCCK}$ & SHLE & -- & 31.1 & $08-16-60$ & $\mathrm{~S}$ & -- & Gardenier & Well deepened in 1959 to increase yield \\
\hline Re-723 & 111ALVM & GRVL & 0 & 7.32 & $07-17-60$ & $S$ & -- & -- & Well may be in direct connection with stream \\
\hline Re-724 & 377SCCK & SHLE & 87 & 40.1 & $04-29-60$ & $\mathrm{~S}$ & 8.50 & Shaver & -- \\
\hline Re-725 & 377SCCK & SHLE & 0 & 77.7 & $04-29-60$ & $\mathrm{~S}$ & -- & Shaver & Well may also tap sand \& gravel above rock \\
\hline Re-726 & 112LAKE & SDST & 0 & 2.00 & $05-09-60$ & $\mathrm{~S}$ & -- & -- & -- \\
\hline Re-727 & 364NMKL & SHLE & -- & 109 & $08-09-60$ & $\mathrm{~S}$ & -- & Seaburger & -- \\
\hline
\end{tabular}


ผ Appendix 1. Records of wells in the Schodack-Kinderhook area, Rensselaer and Columbia Counties, N.Y. A. Wells north of $42^{\circ} 30^{\prime}$

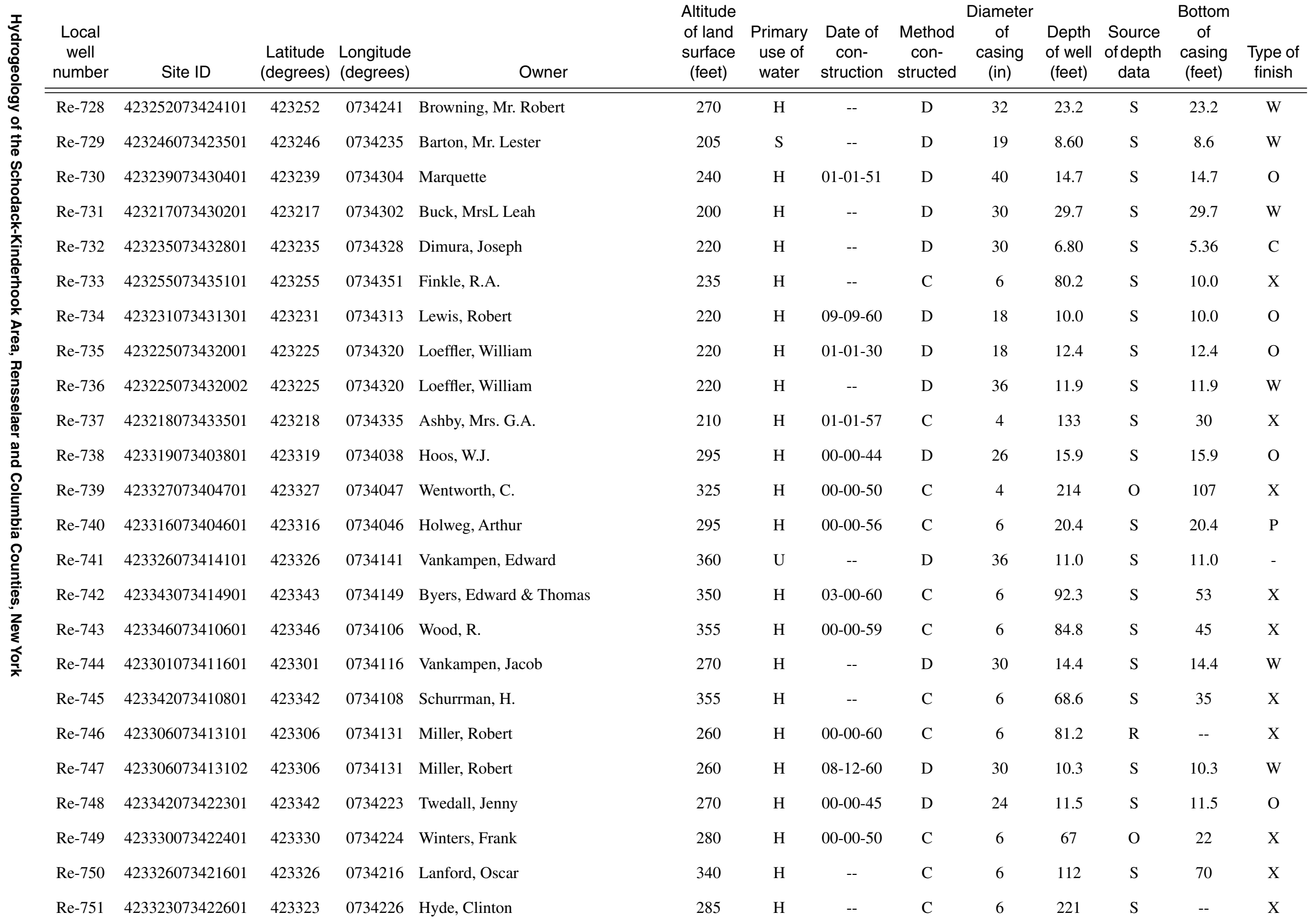


Appendix 1. Records of wells in the Schodack-Kinderhook area, Rensselaer and Columbia Counties, N.Y.

A. Wells north of $42^{\circ} 30^{\prime}$.

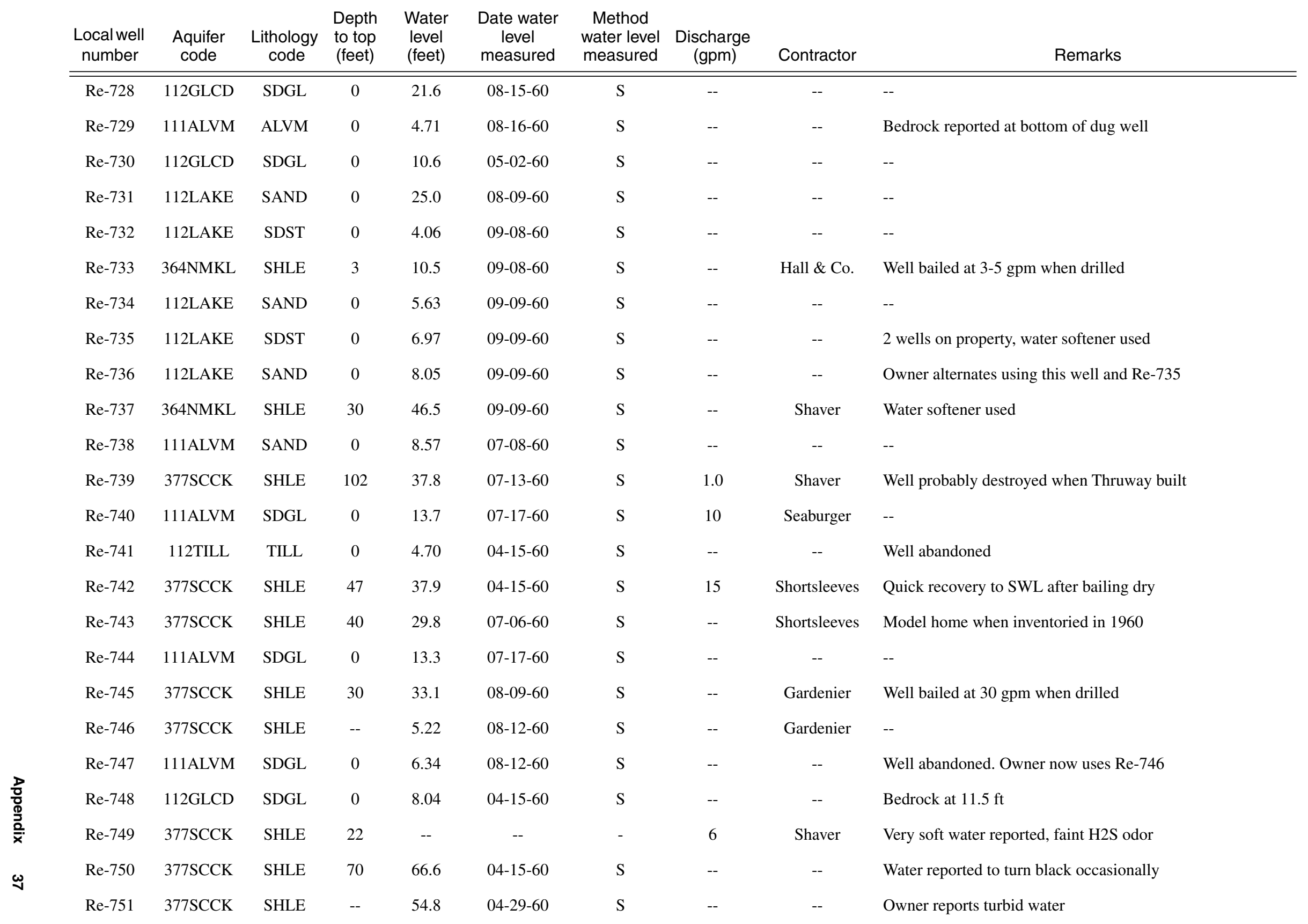


W Appendix 1. Records of wells in the Schodack-Kinderhook area, Rensselaer and Columbia Counties, N.Y. A. Wells north of $42^{\circ} 30^{\prime}$

\begin{tabular}{|c|c|c|c|c|c|c|c|c|c|c|c|c|c|}
\hline $\begin{array}{c}\text { Local } \\
\text { well } \\
\text { number }\end{array}$ & Site ID & $\begin{array}{l}\text { Latitude } \\
\text { (degrees) }\end{array}$ & $\begin{array}{r}\text { Longitude } \\
\text { (degrees) }\end{array}$ & Owner & $\begin{array}{l}\text { Altitude } \\
\text { of land } \\
\text { surface } \\
\text { (feet) }\end{array}$ & $\begin{array}{c}\text { Primary } \\
\text { use of } \\
\text { water }\end{array}$ & $\begin{array}{c}\text { Date of } \\
\text { con- } \\
\text { struction }\end{array}$ & $\begin{array}{l}\text { Method } \\
\text { con- } \\
\text { structed }\end{array}$ & $\begin{array}{l}\text { Diameter } \\
\text { of } \\
\text { casing } \\
\text { (in) }\end{array}$ & $\begin{array}{c}\text { Depth } \\
\text { of well } \\
\text { (feet) }\end{array}$ & $\begin{array}{c}\text { Source } \\
\text { of depth } \\
\text { data }\end{array}$ & $\begin{array}{l}\text { Bottom } \\
\text { of } \\
\text { casing } \\
\text { (feet) }\end{array}$ & $\begin{array}{c}\text { Type of } \\
\text { finish }\end{array}$ \\
\hline Re-752 & 423302073422401 & 423302 & 0734224 & Jorden, Harold & 250 & $\mathrm{H}$ & -- & $\mathrm{C}$ & 6 & 72.3 & $S$ & -- & $\mathrm{X}$ \\
\hline Re-753 & 423432073414701 & 423432 & 0734147 & Haswell, Richard & 355 & $\mathrm{H}$ & $00-00-57$ & $\mathrm{C}$ & 6 & 72.9 & $S$ & -- & $\mathrm{X}$ \\
\hline $\mathrm{Re}-754$ & 423442073414601 & 423442 & 0734146 & Goodman, J.D. & 350 & $\mathrm{H}$ & $00-00-57$ & $\mathrm{C}$ & 6 & 121 & $\mathrm{~S}$ & -- & $\mathrm{X}$ \\
\hline Re-755 & 423443073415101 & 423443 & 0734151 & O'Hara, William & 350 & $\mathrm{H}$ & -- & $\mathrm{C}$ & 6 & 47.3 & $S$ & 32 & $\mathrm{X}$ \\
\hline Re-756 & 423419073412001 & 423419 & 0734120 & Sovisky & 360 & $\mathrm{H}$ & $00-00-50$ & $\mathrm{C}$ & 6 & 43.5 & $S$ & -- & $\mathrm{X}$ \\
\hline Re-757 & 423420073412201 & 423420 & 0734122 & Sovisky, Mr. & 350 & $\mathrm{H}$ & -- & $\mathrm{C}$ & 6 & 18.3 & $S$ & 18.3 & $\mathrm{O}$ \\
\hline Re-758 & 423422073412401 & 423422 & 0734124 & Sovisky & 355 & $\mathrm{H}$ & -- & $\mathrm{C}$ & 6 & 141 & $S$ & -- & $\mathrm{X}$ \\
\hline Re-759 & 423403073421901 & 423403 & 0734219 & Hartnegel, Carl & 280 & $\mathrm{H}$ & -- & $\mathrm{C}$ & 6 & 56.3 & $S$ & 15 & $\mathrm{X}$ \\
\hline Re-760 & 423404073421602 & 423404 & 0734216 & Hartnagel, Carl & 290 & $\mathrm{H}$ & $00-00-55$ & $\mathrm{D}$ & 30 & 20.4 & $S$ & 20.4 & $\mathrm{O}$ \\
\hline Re-761 & 423455073421101 & 423455 & 0734211 & Catino, S. & 320 & $\mathrm{H}$ & $05-02-60$ & $\mathrm{C}$ & 6 & 101 & $\mathrm{~S}$ & -- & $\mathrm{X}$ \\
\hline Re-762 & 423547073415101 & 423547 & 0734151 & Wooding & 335 & $\mathrm{H}$ & $00-00-20$ & $\mathrm{C}$ & 6 & 73.7 & $\mathrm{~S}$ & -- & $\mathrm{X}$ \\
\hline Re-763 & 423515073412701 & 423515 & 0734127 & Goss, $\mathrm{H}$. & 450 & $\mathrm{H}$ & $06-00-60$ & $\mathrm{C}$ & 6 & 131 & $S$ & 58 & $X$ \\
\hline Re-764 & 423505073412801 & 423505 & 0734128 & Goss & 460 & $\mathrm{H}$ & $07-07-60$ & $\mathrm{C}$ & 6 & 184 & $\mathrm{~S}$ & 45 & $\mathrm{X}$ \\
\hline Re-766 & 423504073421301 & 423504 & 0734213 & Griffin, Francis & 290 & $\mathrm{H}$ & -- & $\mathrm{C}$ & 6 & 50.8 & $\mathrm{~S}$ & 35 & $X$ \\
\hline Re-767 & 423552073420401 & 423552 & 0734204 & Beuth, Phillip & 280 & $\mathrm{H}$ & $00-00-57$ & $\mathrm{C}$ & 6 & 65.7 & $\mathrm{~S}$ & -- & $\mathrm{X}$ \\
\hline Re-768 & 423554073421201 & 423554 & 0734212 & Jones, Milton & 265 & $\mathrm{H}$ & $00-00-55$ & $\mathrm{C}$ & -- & 91.1 & $S$ & -- & $\mathrm{X}$ \\
\hline Re-769 & 423559073420301 & 423559 & 0734203 & Roher, Donald & 270 & $\mathrm{H}$ & $00-00-58$ & $\mathrm{C}$ & 6 & 125 & $S$ & -- & $X$ \\
\hline $\operatorname{Re}-770$ & 423548073420301 & 423548 & 0734203 & Harrington, Ronald & 280 & $\mathrm{H}$ & $03-00-60$ & $\mathrm{C}$ & 6 & 41.9 & S & 35 & $X$ \\
\hline Re-771 & 423530073424701 & 423530 & 0734247 & Canaday, Bernard L. & 280 & $\mathrm{H}$ & -- & $\mathrm{C}$ & 6 & 91.8 & $S$ & -- & $\mathrm{X}$ \\
\hline Re-772 & 423523073425301 & 423523 & 0734253 & Vanloan, Dale & 275 & $\mathrm{H}$ & -- & $\mathrm{C}$ & 6 & 134 & $\mathrm{~S}$ & -- & $X$ \\
\hline Re-773 & 423507073425201 & 423507 & 0734252 & Thiele, Karl & 260 & $\mathrm{H}$ & -- & $\mathrm{C}$ & 6 & 85.6 & $\mathrm{~S}$ & -- & $X$ \\
\hline Re-774 & 423532073423702 & 423532 & 0734237 & East Greenbush-Little League Site & 261.87 & $\mathrm{U}$ & $05-00-59$ & $\mathrm{C}$ & 6 & 90 & $\mathrm{R}$ & 90.0 & $\mathrm{O}$ \\
\hline Re-780 & 423146073390901 & 423146 & 0733909 & Nassau Veterinary Clinic & 480 & $\mathrm{C}$ & 09-00-92 & A & 6 & 300 & $\mathrm{D}$ & 40 & $\mathrm{X}$ \\
\hline Re-781 & 423324073373801 & 423324 & 0733738 & Phillips, Thomas & 450 & $\mathrm{H}$ & -- & $\mathrm{C}$ & -- & 146 & $\mathrm{R}$ & -- & $X$ \\
\hline
\end{tabular}


Appendix 1. Records of wells in the Schodack-Kinderhook area, Rensselaer and Columbia Counties, N.Y.

A. Wells north of $42^{\circ} 30^{\prime}$.

\begin{tabular}{|c|c|c|c|c|c|c|c|c|c|}
\hline $\begin{array}{c}\text { Local well } \\
\text { number }\end{array}$ & $\begin{array}{l}\text { Aquifer } \\
\text { code }\end{array}$ & $\begin{array}{l}\text { Lithology } \\
\text { code }\end{array}$ & $\begin{array}{l}\text { Depth } \\
\text { to top } \\
\text { (feet) }\end{array}$ & $\begin{array}{l}\text { Water } \\
\text { level } \\
\text { (feet) }\end{array}$ & $\begin{array}{c}\text { Date water } \\
\text { level } \\
\text { measured }\end{array}$ & $\begin{array}{c}\text { Method } \\
\text { water level } \\
\text { measured }\end{array}$ & $\begin{array}{l}\text { Discharge } \\
\text { (gpm) }\end{array}$ & Contractor & Remarks \\
\hline Re-752 & 377SCCK & SHLE & -- & 38.0 & $08-15-60$ & $\mathrm{~S}$ & -- & -- & -- \\
\hline Re-753 & 377SCCK & SDGL & 0 & 9.20 & $05-08-60$ & $\mathrm{~S}$ & -- & Shaver & Bedrock reported at $40 \mathrm{ft}$ \\
\hline Re-754 & 377SCCK & SHLE & 0 & 18.6 & $05-08-60$ & $\mathrm{~S}$ & -- & -- & -- \\
\hline Re-755 & 377SCCK & SHLE & 27 & 19.5 & $05-08-60$ & $\mathrm{~S}$ & -- & Schaffer & Bailed at $18 \mathrm{gpm}$ when drilled \\
\hline Re-756 & $377 \mathrm{SCCK}$ & SHLE & 0 & 14.8 & $07-07-60$ & $\mathrm{~S}$ & -- & Shortsleeves & -- \\
\hline Re-757 & $112 \mathrm{ICNC}$ & SDGL & 0 & 5.62 & $07-07-60$ & $\mathrm{~S}$ & -- & Shortsleeves & -- \\
\hline $\mathrm{Re}-758$ & 377SCCK & SHLE & 0 & 9.96 & $07-07-60$ & $\mathrm{~S}$ & -- & Shortsleeves & -- \\
\hline Re-759 & 377SCCK & SHLE & 7 & 8.00 & $05-02-60$ & $\mathrm{~S}$ & -- & Gardenier & Owner reports well flows at times in spring \\
\hline Re-760 & $112 \mathrm{GLCD}$ & SDGL & 0 & 12.8 & $05-02-60$ & $\mathrm{~S}$ & -- & Owner & -- \\
\hline Re-761 & 377SCCK & SHLE & 0 & 39.2 & $05-02-60$ & $\mathrm{~S}$ & 5 & -- & -- \\
\hline Re-762 & 377SCCK & SHLE & 0 & 17.2 & $06-29-60$ & $\mathrm{~S}$ & -- & -- & Owner reports $\mathrm{FeOH}$ in water \\
\hline Re-763 & 377SCCK & SHLE & 53 & 46.7 & $07-06-60$ & $\mathrm{~S}$ & -- & Shortsleeves & No pump in well when measured-new home \\
\hline Re-764 & 377SCCK & SHLE & 40 & 48.4 & $07-08-60$ & $\mathrm{~S}$ & 7.5 & Shortsleeves & No pump in well when measured-new home \\
\hline Re-766 & 377SCCK & SHLE & 30 & 33.3 & $05-02-60$ & $\mathrm{~S}$ & -- & -- & -- \\
\hline Re-767 & 377SCCK & SHLE & 0 & 17.1 & $06-29-60$ & $\mathrm{~S}$ & -- & Seaburger & -- \\
\hline Re-768 & 377SCCK & SHLE & 0 & 17.3 & $06-29-60$ & $\mathrm{~S}$ & -- & Seaburger? & -- \\
\hline Re-769 & 377SCCK & SHLE & -- & 27.2 & $06-30-60$ & $\mathrm{~S}$ & -- & Shortsleeves & Water becomes turbid when large amounts used \\
\hline Re-770 & 377SCCK & SHLE & 35 & 3.89 & $06-30-60$ & $\mathrm{~S}$ & -- & Seaburger & Bedrock at $35 \mathrm{ft}$ \\
\hline Re-771 & $377 \mathrm{SCCK}$ & SHLE & 0 & 48.4 & $07-05-60$ & $\mathrm{~S}$ & -- & Shortsleeves & -- \\
\hline Re-772 & 377SCCK & SHLE & -- & 45.7 & $07-05-60$ & $\mathrm{~S}$ & -- & -- & Water softener used \\
\hline Re-773 & 377SCCK & SHLE & 0 & 18.8 & $07-05-60$ & $\mathrm{~S}$ & -- & -- & -- \\
\hline Re-774 & $112 \mathrm{ICNC}$ & SDGL & 70 & 25.1 & $05-00-59$ & $\mathrm{R}$ & 40 & Hall \& Co & DD Data in Myrick Rept \\
\hline Re-780 & 377SCCK & SHLE & 25 & 35 & 09-00-92 & $\mathrm{R}$ & 5 & Ekel, R. & Bedrock at $25 \mathrm{ft}$ \\
\hline Re-781 & 377SCCK & SHLE & -- & 25.3 & $06-05-92$ & $\mathrm{~S}$ & 4 & -- & New pump installed 6-5-92 \\
\hline
\end{tabular}


f Appendix 1. Records of wells in the Schodack-Kinderhook area, Rensselaer and Columbia Counties, N.Y. A. Wells north of $42^{\circ} 30^{\prime}$

\begin{tabular}{|c|c|c|c|c|c|c|c|c|c|c|c|c|c|}
\hline $\begin{array}{c}\text { Local } \\
\text { well } \\
\text { number }\end{array}$ & Site ID & $\begin{array}{l}\text { Latitude } \\
\text { (degrees) }\end{array}$ & $\begin{array}{r}\text { Longitude } \\
\text { (degrees) }\end{array}$ & Owner & $\begin{array}{c}\text { Altitude } \\
\text { of land } \\
\text { surface } \\
\text { (feet) }\end{array}$ & $\begin{array}{c}\text { Primary } \\
\text { use of } \\
\text { water }\end{array}$ & $\begin{array}{l}\text { Date of } \\
\text { con- } \\
\text { struction }\end{array}$ & $\begin{array}{l}\text { Method } \\
\text { con- } \\
\text { structed }\end{array}$ & $\begin{array}{l}\text { Diameter } \\
\text { of } \\
\text { casing } \\
\text { (in) }\end{array}$ & $\begin{array}{l}\text { Depth } \\
\text { of well } \\
\text { (feet) }\end{array}$ & $\begin{array}{c}\text { Source } \\
\text { of depth } \\
\text { data }\end{array}$ & $\begin{array}{c}\text { Bottom } \\
\text { of } \\
\text { casing } \\
\text { (feet) }\end{array}$ & $\begin{array}{l}\text { Type of } \\
\text { finish }\end{array}$ \\
\hline Re-782 & 423638073422401 & 423638 & 0734224 & Rust, T. & 270 & $\mathrm{H}$ & -- & $\mathrm{D}$ & 29 & 15.7 & S & 15.7 & $\mathrm{O}$ \\
\hline $\operatorname{Re}-783$ & 423634073422801 & 423634 & 0734228 & Rosbrook, Mrs. P. & 260 & $\mathrm{H}$ & 00-00-49 & $\mathrm{D}$ & 30 & 15.5 & $S$ & 15.5 & $\mathrm{O}$ \\
\hline Re-784 & 423627073421701 & 423627 & 0734217 & Kingston, Perc & 260 & $\mathrm{H}$ & 00-00-40 & $\mathrm{D}$ & 26 & 13.3 & $S$ & 13.3 & $\mathrm{O}$ \\
\hline Re-785 & 423627073421702 & 423627 & 0734217 & Kingston, Perc & 260 & $\mathrm{U}$ & $00-00-40$ & $\mathrm{D}$ & 25 & 13.8 & $S$ & 13.8 & $\mathrm{O}$ \\
\hline Re-786 & 423628073421901 & 423628 & 0734219 & Bell, Walter & 270 & $\mathrm{H}$ & $00-00-51$ & $\mathrm{D}$ & 24 & 13.7 & $S$ & 14 & $\mathrm{O}$ \\
\hline Re-788 & 423637073421901 & 423637 & 0734219 & Duprey, Kathleen & 280 & $\mathrm{H}$ & -- & $\mathrm{D}$ & 24 & 22.4 & $S$ & 23 & $\mathrm{C}$ \\
\hline $\operatorname{Re}-789$ & 423629073422601 & 423629 & 0734226 & Ross, Frank H. & 270 & $\mathrm{H}$ & -- & $\mathrm{D}$ & 24 & 23.8 & $\mathrm{~S}$ & 23.8 & $\mathrm{O}$ \\
\hline Re-790 & 423623073422501 & 423623 & 0734225 & Andriano, F. & 270 & $\mathrm{H}$ & -- & $\mathrm{D}$ & 24 & 17.2 & $S$ & 17.2 & $\mathrm{O}$ \\
\hline Re-791 & 423626073433301 & 423626 & 0734333 & Town E. Greenbush, Laraway Site & 224.23 & $\mathrm{U}$ & 04-00-59 & $\mathrm{C}$ & 8 & 80.5 & $\mathrm{R}$ & 70 & $S$ \\
\hline Re-792 & 423627073433301 & 423627 & 0734333 & Town E. Greenbush, Laraway Site & 223.95 & $\mathrm{U}$ & 04-00-59 & $\mathrm{C}$ & 6 & 102 & $\mathrm{O}$ & 102 & $\mathrm{O}$ \\
\hline Re-793 & 423627073433601 & 423627 & 0734336 & Town E. Greenbush, Laraway Site & 223.09 & $\mathrm{U}$ & $04-00-59$ & $\mathrm{C}$ & 6 & 80 & $\mathrm{O}$ & 80 & $\mathrm{O}$ \\
\hline Re-794 & 423626073433101 & 423626 & 0734331 & Town E. Greenbush, Laraway Site & 222.18 & $\mathrm{U}$ & $04-00-59$ & $\mathrm{C}$ & 6 & 115 & $\mathrm{R}$ & 115 & $\mathrm{O}$ \\
\hline Re-795 & 423626073433302 & 423626 & 0734333 & USGS-Laraway Site & 230 & $\mathrm{U}$ & $11-14-60$ & B & 1.25 & 16.7 & $S$ & 15.2 & $\mathrm{~T}$ \\
\hline Re-796 & 423720073413801 & 423720 & 0734138 & Kemmy, Joseph F. & 320 & $\mathrm{H}$ & -- & $\mathrm{D}$ & 36 & 16.4 & $S$ & 20 & W \\
\hline Re-798 & 423720073420401 & 423720 & 0734204 & Gannon, Richard & 340 & $\mathrm{H}$ & $00-00-53$ & $\mathrm{C}$ & 6 & 172 & $S$ & 20 & $X$ \\
\hline Re-799 & 423709073420301 & 423709 & 0734203 & Sliter, John W. & 320 & $\mathrm{H}$ & $00-00-47$ & $\mathrm{C}$ & 6 & 102 & S & -- & $X$ \\
\hline Re- 800 & 423707073423001 & 423707 & 0734230 & Danner, Joseph & 260 & $\mathrm{H}$ & -- & $\mathrm{C}$ & 6 & 119 & $S$ & -- & $\mathrm{X}$ \\
\hline $\operatorname{Re}-801$ & 423707073421301 & 423707 & 0734213 & Longacker, Robert & 320 & $\mathrm{H}$ & $00-00-58$ & $\mathrm{C}$ & 6 & 228 & $S$ & 80 & $X$ \\
\hline Re-802 & 423703073423601 & 423703 & 0734236 & Hepinstall, George & 210 & $\mathrm{H}$ & $00-00-56$ & $\mathrm{C}$ & 6 & 82.8 & $\mathrm{~S}$ & -- & $\mathrm{X}$ \\
\hline Re-803 & 423710073425201 & 423710 & 0734252 & Newbury, Robert E. & 280 & $\mathrm{H}$ & $00-00-50$ & $\mathrm{C}$ & 6 & 123 & S & -- & $\mathrm{X}$ \\
\hline Re-804 & 423726073420601 & 423726 & 0734206 & Sahxby, F. & 330 & $\mathrm{H}$ & $08-18-60$ & $\mathrm{C}$ & 6 & 102 & S & 22 & $\mathrm{X}$ \\
\hline Re-805 & 423051073414001 & 423051 & 0734140 & Russel, Kent & 265 & $\mathrm{H}$ & -- & $\mathrm{C}$ & 6 & 63.9 & $S$ & 30 & $X$ \\
\hline Re-806 & 423538073422901 & 423538 & 0734229 & East Greenbush-Little League Site & 244.67 & $\mathrm{U}$ & $05-00-59$ & $\mathrm{C}$ & 6 & 80 & $\mathrm{D}$ & 80 & $\mathrm{O}$ \\
\hline Re-807 & 423532073423101 & 423532 & 0734231 & East Greenbush-Little League Site & 259.74 & $\mathrm{U}$ & $05-00-59$ & $\mathrm{C}$ & 6 & 102 & $\mathrm{R}$ & 102 & $\mathrm{O}$ \\
\hline
\end{tabular}


Appendix 1. Records of wells in the Schodack-Kinderhook area, Rensselaer and Columbia Counties, N.Y.

A. Wells north of $42^{\circ} 30^{\prime}$.

\begin{tabular}{|c|c|c|c|c|c|c|c|c|c|}
\hline $\begin{array}{l}\text { Local well } \\
\text { number }\end{array}$ & $\begin{array}{l}\text { Aquifer } \\
\text { code }\end{array}$ & $\begin{array}{l}\text { Lithology } \\
\text { code }\end{array}$ & $\begin{array}{l}\text { Depth } \\
\text { to top } \\
\text { (feet) }\end{array}$ & $\begin{array}{l}\text { Water } \\
\text { level } \\
\text { (feet) }\end{array}$ & $\begin{array}{c}\text { Date water } \\
\text { level } \\
\text { measured }\end{array}$ & $\begin{array}{c}\text { Method } \\
\text { water level } \\
\text { measured }\end{array}$ & $\begin{array}{c}\text { Discharge } \\
\text { (gpm) }\end{array}$ & Contractor & Remarks \\
\hline Re-782 & 112LAKE & SAND & 0 & 9.53 & $06-23-60$ & S & -- & -- & -- \\
\hline Re-783 & 112LAKE & SAND & 0 & 11.4 & $06-23-60$ & $S$ & -- & -- & Water softener used \\
\hline Re-784 & 112LAKE & SAND & 0 & 8.06 & $06-23-60$ & S & -- & -- & -- \\
\hline $\operatorname{Re}-785$ & 112LAKE & SAND & 0 & 9.23 & $06-23-60$ & S & -- & -- & -- \\
\hline Re-786 & 112LAKE & SAND & 0 & 9.05 & $06-23-60$ & $\mathrm{~S}$ & -- & Hall & Well abandoned \\
\hline Re-788 & 112LAKE & SAND & 0 & 18.9 & $06-27-60$ & $S$ & -- & -- & -- \\
\hline Re-789 & 112LAKE & SAND & 0 & 13.1 & $06-27-60$ & S & -- & -- & -- \\
\hline $\operatorname{Re}-790$ & 112LAKE & SAND & 0 & 11.2 & $06-27-60$ & $\mathrm{~S}$ & -- & -- & Well deepened in summer of 1957 \\
\hline Re-791 & $112 \mathrm{ICNC}$ & SDGL & 40 & 7.66 & $04-17-60$ & S & 400 & Hall \& Co & Aquifer test in Myrick Rept \\
\hline Re-792 & $112 \mathrm{ICNC}$ & SDGL & 40 & 16.2 & $05-25-59$ & $\mathrm{R}$ & -- & Hall \& Co & DD plot \& analysis in Myrick Rept \\
\hline Re-793 & $112 \mathrm{ICNC}$ & SDGL & 51 & 15.1 & $05-25-59$ & $\mathrm{R}$ & -- & Hall \& Co & DD plot of test data in Myrick Rept \\
\hline Re-794 & $112 \mathrm{ICNC}$ & SDGL & 53 & 14.5 & $05-25-59$ & $\mathrm{R}$ & -- & Hall \& Co & DD plot and analysis in Myrick Rept \\
\hline Re-795 & 112LAKE & $\mathrm{SDCl}$ & 0 & 5.66 & $11-19-60$ & S & -- & USGS & USGS 1.25-inch observation well \\
\hline Re-796 & $112 \mathrm{ICNC}$ & SDGL & 0 & 13.2 & $06-22-60$ & S & -- & -- & Well fills with fine sand Well ends on shale. \\
\hline Re-798 & 377SCCK & SHLE & 20 & 18.1 & $06-21-60$ & $S$ & -- & Shortsleeves & Thin outwash s\&g over bedrock \\
\hline Re-799 & 377SCCK & SHLE & -- & 28.5 & $06-21-60$ & $S$ & -- & Seaburger & -- \\
\hline Re-800 & 377SCCK & SHLE & -- & 49.5 & $06-21-60$ & $S$ & -- & -- & Hydrogen sulfide reported \\
\hline Re-801 & 377SCCK & SHLE & -- & 47.9 & $06-22-60$ & $\mathrm{~S}$ & 1.5 & Shaver & -- \\
\hline Re-802 & 377SCCK & SHLE & -- & 30.5 & $06-28-60$ & $S$ & -- & Johnston, R. & Water softener used \\
\hline Re-803 & 377SCCK & SHLE & 25 & 31.1 & $06-28-60$ & $S$ & 60 & Seaburger & -- \\
\hline Re-804 & 377SCCK & SHLE & 12 & 27.8 & $08-19-60$ & S & 4 & Shortsleeves & No pump in well when measured-new house \\
\hline Re-805 & 377SCCK & SHLE & 30 & 4.16 & $09-07-60$ & S & -- & Gardenier & Well user Van Hosen Hgts Water Works Co \\
\hline Re-806 & $112 \mathrm{ICNC}$ & SDGL & 40 & 7.93 & $05-00-59$ & $\mathrm{R}$ & 20 & Hall \& Co & DD plot in Myrick Rept \\
\hline Re-807 & $112 \mathrm{ICNC}$ & SDGL & 40 & 21.2 & $05-00-59$ & $\mathrm{R}$ & 40 & Hall \& Co & DD plot in Myrick Rept \\
\hline
\end{tabular}


i Appendix 1. Records of wells in the Schodack-Kinderhook area, Rensselaer and Columbia Counties, N.Y. A. Wells north of $42^{\circ} 30^{\prime}$

\begin{tabular}{|c|c|c|c|c|c|c|c|c|c|c|c|c|c|}
\hline 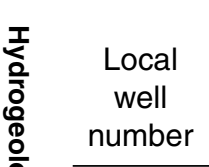 & Site ID & $\begin{array}{l}\text { Latitude } \\
\text { (degrees) }\end{array}$ & $\begin{array}{l}\text { Longitude } \\
\text { (degrees) }\end{array}$ & Owner & $\begin{array}{l}\text { Altitude } \\
\text { of land } \\
\text { surface } \\
\text { (feet) }\end{array}$ & $\begin{array}{c}\text { Primary } \\
\text { use of } \\
\text { water }\end{array}$ & $\begin{array}{l}\text { Date of } \\
\text { con- } \\
\text { struction }\end{array}$ & \multicolumn{2}{|c|}{$\begin{array}{cc} & \text { Diameter } \\
\text { Method } & \text { of } \\
\text { con- } & \text { casing } \\
\text { structed } & \text { (in) }\end{array}$} & $\begin{array}{l}\text { Depth } \\
\text { of well } \\
\text { (feet) }\end{array}$ & $\begin{array}{l}\text { Source } \\
\text { of depth } \\
\text { data }\end{array}$ & $\begin{array}{l}\text { Bottom } \\
\text { of } \\
\text { casing } \\
\text { (feet) }\end{array}$ & $\begin{array}{l}\text { Type of } \\
\text { finish }\end{array}$ \\
\hline Re-808 & 423530073423501 & 423530 & 0734235 & East Greenbush-Little League Site & 259.90 & $\mathrm{U}$ & $05-00-59$ & $\mathrm{C}$ & 6 & 90 & $\mathrm{R}$ & 90 & $\mathrm{O}$ \\
\hline \multirow{2}{*}{$\begin{array}{ll}\vec{F} & \operatorname{Re}-810 \\
\text { के } & \\
\text { ஸे } & \\
\text { م } & \operatorname{Re}-811\end{array}$} & 423525073421902 & 423525 & 0734219 & East Greenbush Water \& Improve Co & 270 & $\mathrm{P}$ & -- & $\mathrm{C}$ & -- & -- & - & -- & $\mathrm{S}$ \\
\hline & 423541073431801 & 423541 & 0734318 & East Greenbush, Witbeck Site 1 & 216.08 & $\mathrm{U}$ & $09-00-59$ & $\mathrm{C}$ & 12 & 105 & $\mathrm{D}$ & 90 & S \\
\hline 产 $\quad$ Re-812 & 423541073431802 & 423541 & 0734318 & East Greenbush, Witbeck Site 1 & 215.71 & $\mathrm{U}$ & $09-00-59$ & $\mathrm{C}$ & 6 & 99 & $\mathrm{R}$ & 99 & $\mathrm{X}$ \\
\hline \multirow{2}{*}{$\begin{array}{ll}\frac{1}{\bar{̄}} & \operatorname{Re}-813 \\
\frac{0}{0} & \\
\frac{0}{\overline{0}} & \operatorname{Re}-814\end{array}$} & 423539073431801 & 423539 & 0734318 & East Greenbush, Witbeck Site 1 & 219.16 & $\mathrm{U}$ & 09-00-59 & $\mathrm{C}$ & 6 & 99 & $\mathrm{R}$ & 99 & $\mathrm{O}$ \\
\hline & 423535073431701 & 423535 & 0734317 & East Greenbush, Witbeck Site 1 & 221.47 & $\mathrm{U}$ & 09-00-59 & $\mathrm{C}$ & 6 & 96 & $\mathrm{R}$ & 96 & $\mathrm{O}$ \\
\hline \multirow{2}{*}{ 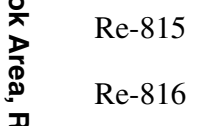 } & 423504073430401 & 423504 & 0734304 & Sultan, Peter & 242 & $\mathrm{H}$ & $04-00-60$ & $\mathrm{C}$ & 6 & 130 & $\mathrm{R}$ & 80 & $\mathrm{X}$ \\
\hline & 423635073414201 & 423635 & 0734142 & Lindenmeyer, F. J. & 340 & $\mathrm{H}$ & -- & $\mathrm{D}$ & -- & 4.5 & S & 4.5 & W \\
\hline \multirow{2}{*}{ 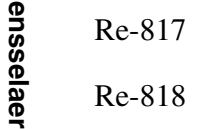 } & 423635073414301 & 423635 & 0734143 & Lindenmeyer, F. J. & 330 & $\mathrm{H}$ & -- & $\mathrm{D}$ & -- & 17.3 & $S$ & 17.3 & W \\
\hline & 423603073415101 & 423603 & 0734151 & Templeton, Hugo & 295 & $\mathrm{H}$ & -- & $\mathrm{C}$ & 6 & 72.4 & $S$ & -- & $\mathrm{X}$ \\
\hline \multirow{2}{*}{ 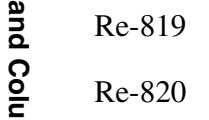 } & 423659073420801 & 423659 & 0734210 & Harrington, Royal & 305 & $\mathrm{H}$ & $00-00-32$ & $\mathrm{C}$ & 6 & 112 & $S$ & -- & $\mathrm{X}$ \\
\hline & 423650073421301 & 423650 & 0734213 & Haselton, E. W. & 280 & $\mathrm{H}$ & -- & $\mathrm{D}$ & 48 & 16.8 & $S$ & 16.8 & W \\
\hline Re-821 & 423639073421301 & 423639 & 0734213 & Everson, C. G. & 290 & $\mathrm{H}$ & -- & $\mathrm{C}$ & 6 & 88.7 & $S$ & 80 & $\mathrm{X}$ \\
\hline $\operatorname{Re}-822$ & 423107073422901 & 423107 & 0734229 & Walsh, Mr. & 245 & $\mathrm{H}$ & -- & $\mathrm{C}$ & 6 & 114 & $\mathrm{O}$ & 96 & - \\
\hline Re-823 & 423103073412501 & 423104 & 0734126 & Stockman, James & 285 & $\mathrm{H}$ & -- & $\mathrm{C}$ & 6 & 48 & $S$ & 48 & $\mathrm{O}$ \\
\hline Re-824 & 423119073411101 & 423131 & 0734108 & Bourdion, A.P. & 305 & $\mathrm{H}$ & 09-08-60 & $\mathrm{C}$ & 4 & 66.3 & $S$ & 66.3 & $\mathrm{O}$ \\
\hline Re- 825 & 423224073404201 & 423224 & 0734042 & Smith, T. & 350 & $\mathrm{H}$ & -- & $\mathrm{C}$ & 6 & 83.8 & $S$ & -- & $\mathrm{X}$ \\
\hline $\operatorname{Re}-826$ & 423340073405401 & 423340 & 0734054 & Belliveau, Leo & 355 & $\mathrm{P}$ & -- & $\mathrm{C}$ & 6 & 220 & $S$ & -- & $\mathrm{X}$ \\
\hline $\operatorname{Re}-827$ & 423122073411201 & 423121 & 0734112 & Battisti Water Supply Corp. & 290 & $\mathrm{P}$ & $00-00-48$ & $\mathrm{C}$ & 8 & 36 & $\mathrm{O}$ & 36 & $\mathrm{~S}$ \\
\hline Re-828 & 423122073411202 & 423121 & 0734112 & Battisti Water Supply Corp. & 290 & $\mathrm{P}$ & $00-00-48$ & $\mathrm{C}$ & 8 & 36 & $\mathrm{O}$ & 36 & $\mathrm{~S}$ \\
\hline $\operatorname{Re}-829$ & 423411073420901 & 423411 & 0734209 & Hendrichs & 350 & $\mathrm{H}$ & $00-00-55$ & $\mathrm{C}$ & 6 & 162 & $S$ & 20 & $\mathrm{X}$ \\
\hline Re-830 & 423325073414301 & 423325 & 0734143 & Vankampen, Edward & 350 & - & $00-00-46$ & $\mathrm{C}$ & 6 & 240 & $\mathrm{R}$ & -- & - \\
\hline $\operatorname{Re}-831$ & 423133073411101 & 423133 & 0734111 & Beaudoin, A. P. & 320 & $\mathrm{H}$ & $07-00-60$ & $\mathrm{C}$ & 4 & 81 & $\mathrm{O}$ & 81 & $\mathrm{O}$ \\
\hline Re-1008 & 423240073405001 & 423240 & 0734050 & Unknown & 350 & $\mathrm{H}$ & $00-00-79$ & $\mathrm{C}$ & 6 & 226 & $\mathrm{R}$ & 72 & $\mathrm{X}$ \\
\hline
\end{tabular}


Appendix 1. Records of wells in the Schodack-Kinderhook area, Rensselaer and Columbia Counties, N.Y.

A. Wells north of $42^{\circ} 30^{\prime}$.

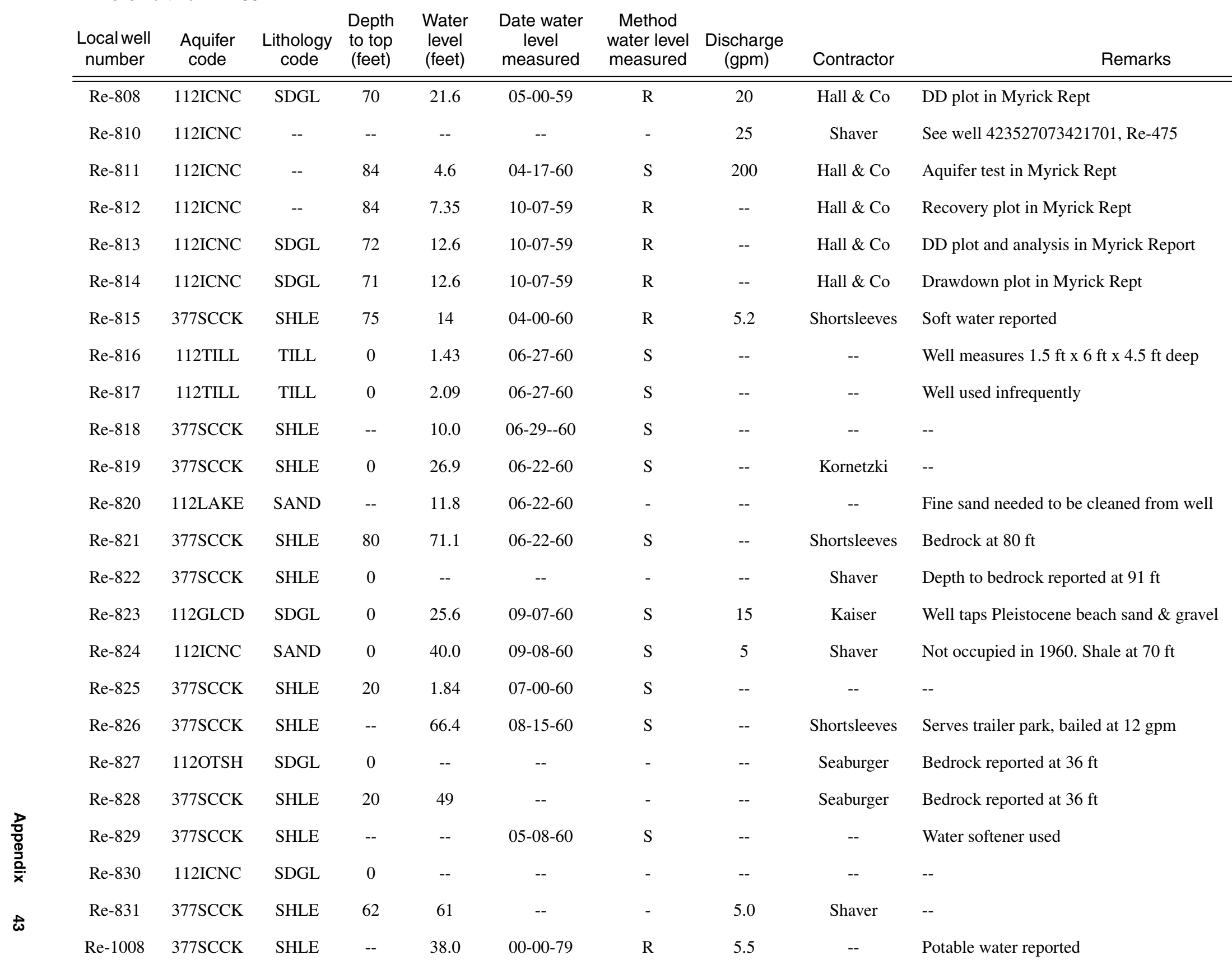


A Appendix 1. Records of wells in the Schodack-Kinderhook area, Rensselaer and Columbia Counties, N.Y. A. Wells north of $42^{\circ} 30^{\prime}$

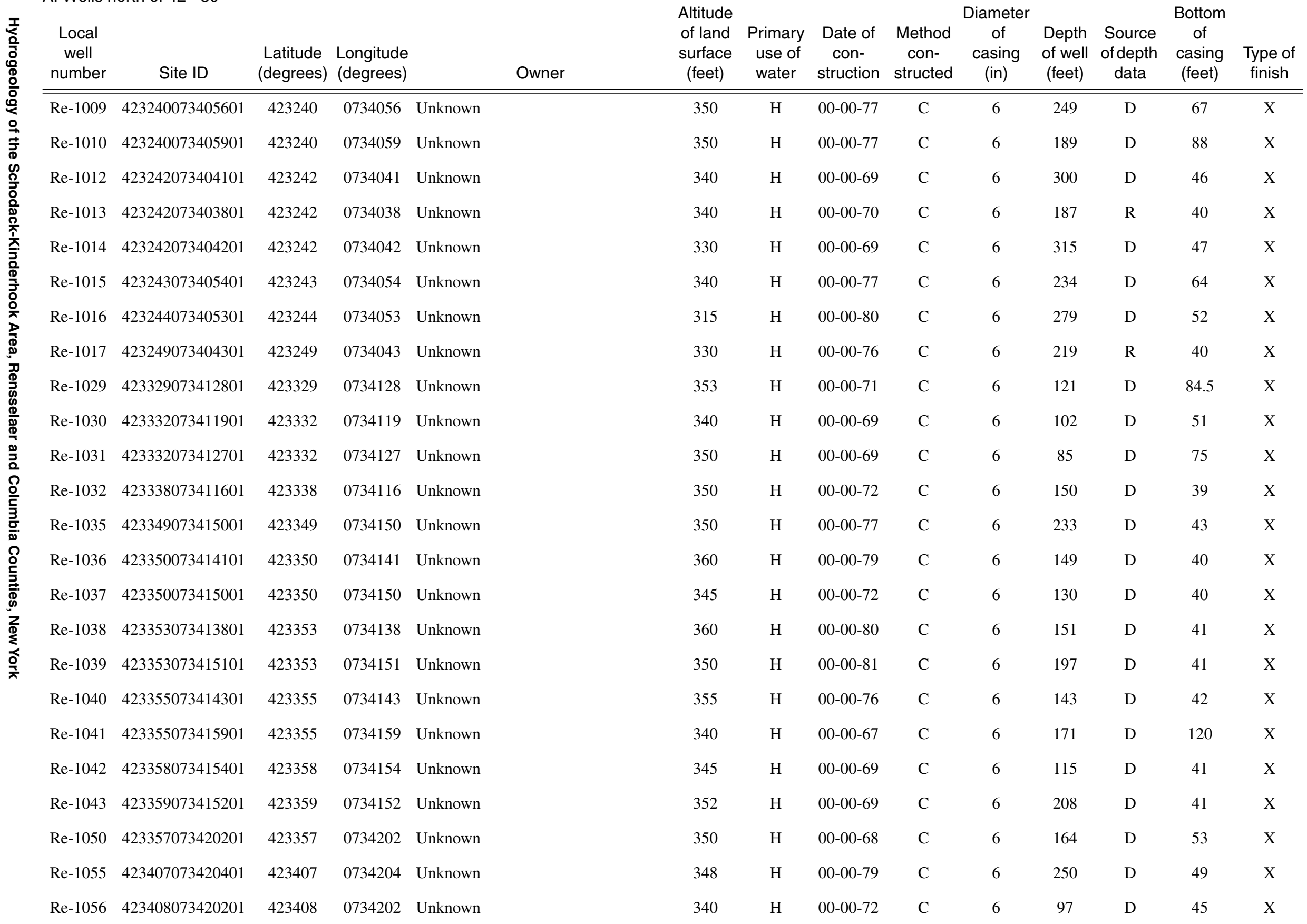


Appendix 1. Records of wells in the Schodack-Kinderhook area, Rensselaer and Columbia Counties, N.Y.

A. Wells north of $42^{\circ} 30^{\prime}$.

\begin{tabular}{|c|c|c|c|c|c|c|c|c|c|c|}
\hline $\begin{array}{l}\text { Local well } \\
\text { number }\end{array}$ & $\begin{array}{l}\text { Aquifer } \\
\text { code }\end{array}$ & $\begin{array}{l}\text { Lithology } \\
\text { code }\end{array}$ & $\begin{array}{l}\text { Depth } \\
\text { to top } \\
\text { (feet) }\end{array}$ & $\begin{array}{l}\text { Water } \\
\text { level } \\
\text { (feet) }\end{array}$ & $\begin{array}{l}\text { Date water } \\
\text { level } \\
\text { measured }\end{array}$ & $\begin{array}{c}\text { Method } \\
\text { water level } \\
\text { measured }\end{array}$ & $\begin{array}{l}\text { Discharge } \\
\quad(\mathrm{gpm})\end{array}$ & Contractor & & Remarks \\
\hline Re-1009 & $377 \mathrm{SCCK}$ & SHLE & 64 & 20 & $00-00-77$ & $\mathrm{R}$ & 4 & -- & Potable water reported & \\
\hline Re-1010 & 377SCCK & SHLE & 86 & 20 & $00-00-77$ & $\mathrm{R}$ & 5 & $\mathrm{R}$ & Potable water reported & \\
\hline Re-1012 & 377SCCK & SHLE & 42 & 41 & 00-00-69 & $\mathrm{R}$ & 5 & -- & Potable water reported & \\
\hline Re-1013 & 377SCCK & SHLE & 27 & 24 & $00-00-70$ & $\mathrm{R}$ & 8 & -- & Potable water reported & \\
\hline Re-1014 & 377SCCK & SHLE & 44 & 40 & 00-00-69 & $\mathrm{R}$ & 5.25 & -- & Potable water reported & \\
\hline Re-1015 & 377SCCK & SHLE & 62 & 50 & 00-00-77 & $\mathrm{R}$ & 2.5 & -- & Potable water reported & \\
\hline Re-1016 & 377SCCK & SHLE & 47 & -- & -- & - & 6.0 & -- & Potable water reported & \\
\hline Re-1017 & 377SCCK & SHLE & 33 & 30 & $00-00-76$ & $\mathrm{R}$ & 4.0 & -- & Potable water reported & \\
\hline Re-1029 & 377SCCK & SHLE & 80 & 33 & 00-00-71 & $\mathrm{R}$ & 10 & -- & Potable water reported & \\
\hline Re-1030 & 377SCCK & SHLE & 51 & 16 & 00-00-69 & $\mathrm{R}$ & 30 & -- & Potable water reported & \\
\hline Re-1031 & 377SCCK & SHLE & 72 & 33 & 00-00-69 & $\mathrm{R}$ & 30 & -- & Potable water reported & \\
\hline Re-1032 & 377SCCK & SHLE & 37 & -- & -- & - & 6 & -- & Potable water reported & \\
\hline Re-1035 & 377SCCK & SHLE & 20 & 28 & 00-00-77 & $\mathrm{R}$ & 6.5 & -- & Potable water reported & \\
\hline Re-1036 & 377SCCK & SHLE & 18 & 15 & 00-00-79 & $\mathrm{R}$ & 5.5 & -- & Potable water reported & \\
\hline Re-1037 & 377SCCK & SHLE & 25 & 25 & $00-00-72$ & $\mathrm{R}$ & 5 & -- & Potable water reported & \\
\hline Re-1038 & 377SCCK & SHLE & 12 & 18 & 00-00-80 & $\mathrm{R}$ & 8 & -- & Potable water reported & \\
\hline Re-1039 & 377SCCK & SHLE & 28 & 38 & $00-00-81$ & $\mathrm{R}$ & 5.25 & -- & Potable water reported & \\
\hline Re-1040 & 377SCCK & SHLE & 5 & 20 & $00-00-76$ & $\mathrm{R}$ & 6.5 & -- & Potable water reported & \\
\hline Re-1041 & 377SCCK & SHLE & 120 & 32 & 00-00-67 & $\mathrm{R}$ & 6 & -- & Potable water reported & \\
\hline Re-1042 & 377SCCK & SHLE & 40 & 24 & 00-00-69 & $\mathrm{R}$ & 7.25 & -- & Potable water reported & \\
\hline Re-1043 & 377SCCK & SHLE & 36 & 30 & 00-00-69 & $\mathrm{R}$ & 5 & -- & Potable water reported & \\
\hline Re-1050 & 377SCCK & SHLE & 48 & -- & -- & - & 5 & -- & Potable water reported & \\
\hline Re-1055 & $377 \mathrm{SCCK}$ & SHLE & 47 & 50 & 00-00-79 & $\mathrm{R}$ & 5 & -- & Potable water reported & \\
\hline Re-1056 & 377SCCK & SHLE & 45 & 20 & $00-00-72$ & $\mathrm{R}$ & 11 & -- & -- & \\
\hline
\end{tabular}


के Appendix 1. Records of wells in the Schodack-Kinderhook area, Rensselaer and Columbia Counties, N.Y. A. Wells north of $42^{\circ} 30^{\prime}$

\begin{tabular}{|c|c|c|c|c|c|c|c|c|c|c|c|c|c|}
\hline $\begin{array}{c}\text { Local } \\
\text { well } \\
\text { number }\end{array}$ & Site ID & $\begin{array}{l}\text { Latitude } \\
\text { (degrees) }\end{array}$ & $\begin{array}{l}\text { Longitude } \\
\text { (degrees) }\end{array}$ & Owner & $\begin{array}{c}\text { Altitude } \\
\text { of land } \\
\text { surface } \\
\text { (feet) }\end{array}$ & $\begin{array}{c}\text { Primary } \\
\text { use of } \\
\text { water }\end{array}$ & $\begin{array}{l}\text { Date of } \\
\text { con- } \\
\text { struction }\end{array}$ & $\begin{array}{l}\text { Method } \\
\text { con- } \\
\text { structed }\end{array}$ & $\begin{array}{l}\text { Diameter } \\
\text { of } \\
\text { casing } \\
\text { (in) }\end{array}$ & $\begin{array}{l}\text { Depth } \\
\text { of well } \\
\text { (feet) }\end{array}$ & $\begin{array}{c}\text { Source } \\
\text { of depth } \\
\text { data }\end{array}$ & $\begin{array}{l}\text { Bottom } \\
\text { of } \\
\text { casing } \\
\text { (feet) }\end{array}$ & $\begin{array}{c}\text { Type of } \\
\text { finish }\end{array}$ \\
\hline Re-1057 & 423449073421701 & 423448 & 0734218 & Beach, Robert & 275 & $\mathrm{H}$ & -- & $\mathrm{C}$ & 6 & 178 & $S$ & 58 & $\mathrm{X}$ \\
\hline Re-1071 & 423435073424101 & 423435 & 0734241 & Lanford, O. E. & 220 & $\mathrm{H}$ & $00-00-52$ & $\mathrm{C}$ & 6 & 55 & $\mathrm{O}$ & 55 & $\mathrm{O}$ \\
\hline Re-1073 & 423009073413101 & 423009 & 0734131 & Unknown & 253 & $\mathrm{H}$ & -- & $\mathrm{C}$ & -- & 70 & $\mathrm{R}$ & -- & - \\
\hline Re-1074 & 423010073411901 & 423010 & 0734119 & Unknown & 295 & $\mathrm{H}$ & $00-00-62$ & $\mathrm{C}$ & 6 & 120 & $\mathrm{D}$ & -- & $\mathrm{X}$ \\
\hline Re-1075 & 423050073413901 & 423050 & 0734139 & Unknown & 265 & $\mathrm{H}$ & -- & $\mathrm{C}$ & 6 & -- & - & -- & - \\
\hline Re-1076 & 423051073415301 & 423051 & 0734153 & Unknown & 258 & $\mathrm{H}$ & $00-00-57$ & $\mathrm{C}$ & 6 & 130 & $\mathrm{D}$ & -- & $X$ \\
\hline Re-1077 & 423052073415801 & 423052 & 0734158 & Unknown & 255 & $\mathrm{H}$ & -- & $\mathrm{C}$ & 6 & -- & - & -- & - \\
\hline Re-1078 & 423055073413101 & 423055 & 0734131 & Unknown & 280 & $\mathrm{H}$ & -- & $\mathrm{V}$ & -- & 28 & $\mathrm{R}$ & -- & $\mathrm{T}$ \\
\hline Re-1079 & 423047073423801 & 423047 & 0734238 & Unknown & 251 & $\mathrm{H}$ & $00-00-82$ & $\mathrm{C}$ & 6 & 300 & $\mathrm{D}$ & 106 & $\mathrm{X}$ \\
\hline Re-1080 & 423017073443001 & 423017 & 0734430 & Unknown & 185 & $\mathrm{H}$ & $00-00-63$ & $\mathrm{C}$ & 6 & 107 & $\mathrm{D}$ & 107 & $\mathrm{O}$ \\
\hline Re-1081 & 423103073413101 & 423103 & 0734131 & Unknown & 275 & $\mathrm{H}$ & 00-00-30 & $\mathrm{D}$ & -- & -- & - & -- & - \\
\hline Re-1082 & 423110073412701 & 423110 & 0734127 & Unknown & 280 & $\mathrm{H}$ & $00-00-24$ & $\mathrm{C}$ & -- & -- & - & -- & - \\
\hline Re-1083 & 423112073412601 & 423112 & 0734126 & Unknown & 282 & $\mathrm{H}$ & -- & $\mathrm{D}$ & 75 & 4 & $\mathrm{R}$ & 4 & W \\
\hline Re-1084 & 423129073415401 & 423129 & 0734154 & Unknown & 265 & $\mathrm{H}$ & $00-00-81$ & $\mathrm{C}$ & 6 & 88 & $\mathrm{D}$ & 48 & $X$ \\
\hline Re-1085 & 423129073415701 & 423129 & 0734157 & Unknown & 265 & $\mathrm{H}$ & $00-00-81$ & $\mathrm{C}$ & 6 & 400 & $\mathrm{D}$ & 73 & $\mathrm{X}$ \\
\hline Re-1086 & 423135073412201 & 423135 & 0734122 & Spring, Jan & 315 & $\mathrm{H}$ & $11-25-77$ & A & 6 & 230 & $\mathrm{D}$ & 90 & $\mathrm{X}$ \\
\hline Re-1087 & 423135073412401 & 423135 & 0734124 & Unknown & 305 & $\mathrm{H}$ & 00-00-79 & $\mathrm{C}$ & 6 & 85 & $\mathrm{D}$ & 70 & $X$ \\
\hline Re-1088 & 423137073412301 & 423137 & 0734123 & Unknown & 315 & $\mathrm{H}$ & $00-00-78$ & $\mathrm{C}$ & 6 & 120 & $\mathrm{D}$ & 110 & $\mathrm{X}$ \\
\hline Re-1089 & 423138073412401 & 423138 & 0734124 & Unknown & 315 & $\mathrm{H}$ & $00-00-77$ & $\mathrm{C}$ & 6 & 110 & $\mathrm{D}$ & 100 & $\mathrm{X}$ \\
\hline Re-1090 & 423139073412601 & 423139 & 0734126 & Porpeglia, Jim & 315 & $\mathrm{H}$ & $08-27-77$ & $\mathrm{C}$ & 6 & 177 & G & 98 & $X$ \\
\hline Re-1091 & 423143073412601 & 423143 & 0734126 & Hall, Allen M. & 332 & $\mathrm{H}$ & $06-04-68$ & $\mathrm{C}$ & 6 & 210 & $\mathrm{D}$ & 128 & $\mathrm{X}$ \\
\hline Re-1092 & 423114073422601 & 423114 & 0734226 & Unknown & 251 & $\mathrm{H}$ & $00-00-62$ & $\mathrm{C}$ & 4 & 135 & $\mathrm{D}$ & -- & $\mathrm{X}$ \\
\hline Re-1093 & 423132073422501 & 423132 & 0734225 & Unknown & 250 & $\mathrm{H}$ & $00-00-73$ & $\mathrm{C}$ & 6 & 80 & $\mathrm{R}$ & 79 & $\mathrm{X}$ \\
\hline Re-1094 & 423149073425101 & 423149 & 0734251 & Teator, Raymond & 262 & $\mathrm{H}$ & $00-00-78$ & $\mathrm{C}$ & 6 & 100 & $\mathrm{G}$ & 41 & $X$ \\
\hline
\end{tabular}


Appendix 1. Records of wells in the Schodack-Kinderhook area, Rensselaer and Columbia Counties, N.Y.

A. Wells north of $42^{\circ} 30^{\prime}$.

\begin{tabular}{|c|c|c|c|c|c|c|c|c|c|}
\hline $\begin{array}{l}\text { Local well } \\
\text { number }\end{array}$ & $\begin{array}{l}\text { Aquifer } \\
\text { code }\end{array}$ & $\begin{array}{l}\text { Lithology } \\
\text { code }\end{array}$ & $\begin{array}{l}\text { Depth } \\
\text { to top } \\
\text { (feet) }\end{array}$ & $\begin{array}{l}\text { Water } \\
\text { level } \\
\text { (feet) }\end{array}$ & $\begin{array}{c}\text { Date water } \\
\text { level } \\
\text { measured }\end{array}$ & $\begin{array}{c}\text { Method } \\
\text { water level } \\
\text { measured }\end{array}$ & $\begin{array}{l}\text { Discharge } \\
\text { (gpm) }\end{array}$ & Contractor & Remarks \\
\hline Re-1057 & 377SCCK & SHLE & 55 & -- & -- & - & -- & Kornetzki & WL $17 \mathrm{ft}$, buried well \\
\hline Re-1071 & 112GLCD & SAND & 50 & 20 & $12-07-54$ & $\mathrm{R}$ & 4 & S\&S Well Drl & Owner reports iron, moderate hardness \\
\hline Re-1073 & -- & -- & -- & -- & -- & - & -- & -- & Soft, unlimited water reported \\
\hline Re-1074 & 377SCCK & SHLE & -- & 40 & $00-00-62$ & $\mathrm{R}$ & 8 & -- & Soft water reported \\
\hline Re-1075 & 377SCCK & SHLE & -- & -- & -- & - & -- & -- & Hard water reported \\
\hline Re-1076 & 377SCCK & SHLE & -- & -- & -- & - & 5 & -- & Hard, iron stained water reported \\
\hline Re-1077 & -- & -- & -- & -- & -- & - & -- & -- & Shallow, good taste \& yield, high iron \\
\hline Re-1078 & 112GLCD & GRVL & 20 & -- & -- & - & -- & -- & Owner reports good water quality \\
\hline Re-1079 & 364NMKL & SHLE & 100 & 45 & $00-00-82$ & $\mathrm{R}$ & 3 & -- & Potable \\
\hline Re-1080 & 112GLCD & SDGL & -- & 82 & $00-00-63$ & $\mathrm{R}$ & 12 & -- & Satisfactory quality, water from gravel \\
\hline Re-1081 & 112LAKE & SAND & 0 & -- & -- & - & -- & -- & Soft water reported \\
\hline Re-1082 & -- & -- & -- & -- & -- & - & -- & -- & Adequate yield, good taste reported \\
\hline Re-1083 & 112OTSH & GRVL & 5 & 4.6 & -- & - & -- & -- & Well measures $6 \mathrm{ft} \times 3 \mathrm{ft} \times 4 \mathrm{ft}$ deep \\
\hline Re-1084 & 112OTSH & GRVL & 5 & 3.40 & -- & - & 20 & -- & 1 gpm @ $21 \mathrm{ft}, 3$ gpm @ 28 ft, 10 gpm @ $50 \mathrm{ft}$ \\
\hline Re-1085 & $112 \mathrm{ICNC}$ & SDGL & 21 & 5.82 & $00-00-81$ & $\mathrm{R}$ & 3 & -- & Potable water reported \\
\hline Re-1086 & $112 \mathrm{ICNC}$ & SDGL & 21 & 5.78 & $11-25-77$ & $\mathrm{R}$ & 7 & Hanson & $\mathrm{NO} 3$ as $\mathrm{N}<0.2 \mathrm{mg} / \mathrm{L}, \mathrm{Cl} 8 \mathrm{mg} / \mathrm{L}, 9 / 13 / 88, \mathrm{RCHD}$ \\
\hline Re-1087 & $112 \mathrm{ICNC}$ & SDGL & 10 & .87 & 00-00-79 & $\mathrm{R}$ & 10 & -- & -- \\
\hline Re-1088 & 112LAKE & SDST & 14 & -- & $00-00-78$ & $\mathrm{R}$ & 10 & -- & -- \\
\hline Re-1089 & 112GLCD & $\mathrm{SDCl}$ & 35 & -.6 & 00-00-77 & $\mathrm{R}$ & 8 & -- & -- \\
\hline Re-1090 & 112GLCD & SAND & 50 & -1.5 & $08-27-77$ & $\mathrm{R}$ & 6 & Hanson & $\mathrm{NO} 3$ as $\mathrm{N}<0.2 \mathrm{mg} / \mathrm{L}, \mathrm{Cl} 22 \mathrm{mg} / \mathrm{L} \mathrm{3/14/91,} \mathrm{RCHD}$ \\
\hline Re-1091 & $112 \mathrm{ICNC}$ & SDGL & 0 & 2.5 & 06-04-68 & $\mathrm{R}$ & 6.5 & Shaver & $\mathrm{NO} 3$ as N .04 mg/L, Cl $3.0 \mathrm{mg} / \mathrm{L}$ 6/4/68, RCHD \\
\hline Re-1092 & $112 \mathrm{ICNC}$ & SDGL & 34 & 4 & $00-00-62$ & $\mathrm{R}$ & 15 & -- & Good quality reported \\
\hline Re-1093 & 112GLCD & SDST & 135 & -- & -- & - & 6 & -- & -- \\
\hline Re-1094 & 377SCCK & SHLE & 55 & -- & -- & - & 3 & Kleinhans, A & $\mathrm{NO} 3$ as $\mathrm{N}<0.2 \mathrm{mg} / \mathrm{L}, \mathrm{Cl} 95 \mathrm{mg} / \mathrm{L}, 2 / 23 / 82$, RCHD \\
\hline
\end{tabular}


क Appendix 1. Records of wells in the Schodack-Kinderhook area, Rensselaer and Columbia Counties, N.Y. A. Wells north of $42^{\circ} 30^{\prime}$

\begin{tabular}{|c|c|c|c|c|c|c|c|c|c|c|c|c|c|}
\hline $\begin{array}{c}\text { Local } \\
\text { well } \\
\text { number }\end{array}$ & Site ID & $\begin{array}{l}\text { Latitude } \\
\text { (degrees) }\end{array}$ & $\begin{array}{l}\text { Longitude } \\
\text { (degrees) }\end{array}$ & Owner & $\begin{array}{c}\text { Altitude } \\
\text { of land } \\
\text { surface } \\
\text { (feet) }\end{array}$ & $\begin{array}{c}\text { Primary } \\
\text { use of } \\
\text { water }\end{array}$ & $\begin{array}{l}\text { Date of } \\
\text { con- } \\
\text { struction }\end{array}$ & $\begin{array}{l}\text { Method } \\
\text { con- } \\
\text { structed }\end{array}$ & $\begin{array}{l}\text { Diameter } \\
\text { of } \\
\text { casing } \\
\text { (in) }\end{array}$ & $\begin{array}{l}\text { Depth } \\
\text { of well } \\
\text { (feet) }\end{array}$ & $\begin{array}{c}\text { Source } \\
\text { of depth } \\
\text { data }\end{array}$ & $\begin{array}{c}\text { Bottom } \\
\text { of } \\
\text { casing } \\
\text { (feet) }\end{array}$ & $\begin{array}{l}\text { Type of } \\
\text { finish }\end{array}$ \\
\hline Re-1096 & 423122073432101 & 423122 & 0734321 & Unknown & 225 & $\mathrm{H}$ & -- & $\mathrm{C}$ & 6 & 57 & $\mathrm{D}$ & 56 & $\mathrm{X}$ \\
\hline Re-1097 & 423130073431501 & 423130 & 0734315 & Unknown & 221 & $\mathrm{H}$ & $00-00-76$ & $\mathrm{C}$ & 6 & 45 & $\mathrm{D}$ & 45 & $\mathrm{O}$ \\
\hline Re-1098 & 423134073430501 & 423134 & 0734305 & Unknown & 250 & $\mathrm{H}$ & $00-00-81$ & $\mathrm{C}$ & 6 & 85 & $\mathrm{D}$ & 85 & $\mathrm{O}$ \\
\hline Re-1099 & 423154073434401 & 423154 & 0734344 & Unknown & 227 & $\mathrm{H}$ & -- & $\mathrm{C}$ & 8 & 150 & $\mathrm{D}$ & -- & $\mathrm{X}$ \\
\hline Re-1100 & 423154073434402 & 423154 & 0734344 & Unknown & 227 & $\mathrm{H}$ & $00-00-64$ & $\mathrm{C}$ & 6 & 190 & $\mathrm{D}$ & -- & $X$ \\
\hline Re-1101 & 423156073433301 & 423156 & 0734333 & Unknown & 205 & $\mathrm{H}$ & $00-00-54$ & $\mathrm{C}$ & 6 & 150 & $\mathrm{D}$ & -- & $X$ \\
\hline Re-1102 & 423159073434301 & 423159 & 0734343 & Unknown & 225 & $\mathrm{H}$ & $00-00-59$ & $\mathrm{C}$ & 6 & 180 & $\mathrm{D}$ & -- & $\mathrm{X}$ \\
\hline Re-1103 & 423103073441901 & 423103 & 0734419 & Unknown & 183 & $\mathrm{H}$ & $00-00-82$ & $\mathrm{C}$ & 6 & 415 & $\mathrm{D}$ & 114 & $X$ \\
\hline Re-1104 & 423203073412401 & 423203 & 0734124 & Lyman, William & 333 & $\mathrm{H}$ & $05-08-78$ & $\mathrm{H}$ & 6 & 384 & $\mathrm{G}$ & 125 & $\mathrm{X}$ \\
\hline Re-1105 & 423234073415801 & 423234 & 0734158 & Unknown & 320 & $\mathrm{H}$ & $00-00-71$ & $\mathrm{C}$ & 6 & 236 & $\mathrm{D}$ & 194 & $X$ \\
\hline Re-1106 & 423208073421701 & 423208 & 0734217 & Krug Farms & 280 & $\mathrm{H}$ & -- & $\mathrm{C}$ & 6 & 208 & $\mathrm{D}$ & 41 & $\mathrm{X}$ \\
\hline Re-1107 & 423214073423301 & 423214 & 0734233 & Unknown & 280 & $\mathrm{H}$ & 00-00-09 & $\mathrm{C}$ & 6 & 129 & $\mathrm{D}$ & -- & $\mathrm{X}$ \\
\hline Re-1108 & 423222073423001 & 423222 & 0734230 & Unknown & 280 & $\mathrm{H}$ & $00-00-77$ & $\mathrm{C}$ & 6 & 175 & $\mathrm{D}$ & -- & $\mathrm{X}$ \\
\hline Re-1109 & 423227073421801 & 423227 & 0734218 & Rice, Donald & 320 & $\mathrm{H}$ & $11-18-70$ & $\mathrm{C}$ & 6 & 234 & $\mathrm{D}$ & 156 & $\mathrm{X}$ \\
\hline Re-1110 & 423215073434901 & 423215 & 0734349 & Unknown & 150 & $\mathrm{H}$ & $00-00-68$ & $\mathrm{C}$ & 6 & 85 & $\mathrm{R}$ & 17 & $\mathrm{X}$ \\
\hline Re-1111 & 423223073432201 & 423223 & 0734322 & Unknown & 223 & $\mathrm{U}$ & $00-00-72$ & $\mathrm{C}$ & 6 & 623 & $\mathrm{D}$ & 64 & $\mathrm{X}$ \\
\hline Re-1112 & 423233073431901 & 423233 & 0734319 & Unknown & 222 & $\mathrm{H}$ & $00-00-81$ & $\mathrm{C}$ & 6 & 140 & $\mathrm{D}$ & 140 & $\mathrm{O}$ \\
\hline Re-1113 & 423020073403201 & 423020 & 0734032 & Unknown & 330 & $\mathrm{H}$ & $00-00-58$ & $\mathrm{C}$ & 6 & 46 & $\mathrm{R}$ & 46 & $\mathrm{O}$ \\
\hline Re-1118 & 423305073402201 & 423305 & 0734022 & Polsinello Fuels & 345 & $\mathrm{C}$ & $02-21-90$ & A & 6 & 182 & $\mathrm{D}$ & 73.3 & $\mathrm{X}$ \\
\hline Re-1127 & 423236073430601 & 423236 & 0734306 & Brookview School Dist. No. 12 & 240 & $\mathrm{~T}$ & -- & $\mathrm{D}$ & 60 & 16 & $\mathrm{O}$ & 16 & $\mathrm{~W}$ \\
\hline Re-1128 & 423220073444701 & 423220 & 0734447 & Fort Orange Paper Company & 10 & $\mathrm{U}$ & -- & $\mathrm{C}$ & 8 & 45 & $\mathrm{D}$ & 29 & $\mathrm{G}$ \\
\hline Re-1129 & 423223073445201 & 423223 & 0734452 & Fort Orange Paper Company & 10 & $\mathrm{U}$ & -- & $\mathrm{C}$ & 8 & 73 & $\mathrm{D}$ & 37 & $\mathrm{G}$ \\
\hline Re-1130 & 423221073444901 & 423221 & 0734449 & Fort Orange Paper Company & 10 & $\mathrm{U}$ & -- & $\mathrm{C}$ & 8 & 63 & $\mathrm{D}$ & 37 & G \\
\hline Re-1131 & 423312073401501 & 423312 & 0734015 & Town Of Schodack & 310 & $\mathrm{U}$ & $12-18-87$ & $\mathrm{C}$ & 10 & 39 & $\mathrm{D}$ & 29.5 & $\mathrm{~S}$ \\
\hline
\end{tabular}


Appendix 1. Records of wells in the Schodack-Kinderhook area, Rensselaer and Columbia Counties, N.Y.

A. Wells north of $42^{\circ} 30^{\prime}$.

\begin{tabular}{|c|c|c|c|c|c|c|c|c|c|}
\hline $\begin{array}{c}\text { Local well } \\
\text { number }\end{array}$ & $\begin{array}{l}\text { Aquifer } \\
\text { code }\end{array}$ & $\begin{array}{l}\text { Lithology } \\
\text { code }\end{array}$ & $\begin{array}{l}\text { Depth } \\
\text { to top } \\
\text { (feet) }\end{array}$ & $\begin{array}{l}\text { Water } \\
\text { level } \\
\text { (feet) }\end{array}$ & $\begin{array}{c}\text { Date water } \\
\text { level } \\
\text { measured }\end{array}$ & $\begin{array}{c}\text { Method } \\
\text { water level } \\
\text { measured }\end{array}$ & $\begin{array}{l}\text { Discharge } \\
\text { (gpm) }\end{array}$ & Contractor & Remarks \\
\hline Re-1096 & 377SCCK & SHLE & 20 & 20 & -- & - & -- & -- & $5 \mathrm{gpm}$, poor quality reported \\
\hline Re-1097 & 377SCCK & SHLE & 55 & 31 & -- & - & 8 & -- & Water level fluctuates with Moordener Kill \\
\hline Re-1098 & 377SCCK & SHLE & 8 & -- & -- & - & 10 & -- & -- \\
\hline Re-1099 & 377SCCK & SHLE & 76 & 20 & -- & - & -- & -- & $1 \mathrm{gpm}$, hard, old well, Clear water reported \\
\hline Re-1100 & 377SCCK & SHLE & 100 & 80 & $00-00-64$ & $\mathrm{R}$ & 13 & -- & Clear, hard water reported \\
\hline Re-1101 & 377SCCK & SHLE & 55 & 35 & -- & - & 15 & -- & Hard, Clear water; Slight H2S odor reported \\
\hline Re-1102 & 377SCCK & SHLE & 66 & -- & $00-00-59$ & $\mathrm{R}$ & -- & -- & Hard water, some iron reported, softener used \\
\hline Re-1103 & 377SCCK & SHLE & 20 & 4 & -- & - & -- & -- & Low yield, potable \\
\hline Re-1104 & 377SCCK & SHLE & 47 & 29 & -- & - & 2.5 & Hanson & $\mathrm{NO} 3$ as $\mathrm{N}<0.5 \mathrm{mg} / \mathrm{L}, \mathrm{Cl} 9 \mathrm{mg} / \mathrm{L}, 12 / 12 / 78, \mathrm{RCHD}$ \\
\hline Re-1105 & 377SCCK & SHLE & 57 & 35 & $00-00-71$ & $\mathrm{R}$ & 10 & -- & Driller notes all water from rock \\
\hline Re-1106 & 377SCCK & SHLE & 34 & 38 & -- & - & -- & -- & WL $30 \mathrm{ft}, 8 \mathrm{gpm}$, contact spring near here \\
\hline Re-1107 & 377SCCK & SHLE & 72 & -- & -- & - & -- & -- & $19 \mathrm{gpm}$ yield reported \\
\hline Re-1108 & 377SCCK & SHLE & 65 & -- & -- & - & 20 & -- & -- \\
\hline Re-1109 & $112 \mathrm{GLCD}$ & GRVL & 55 & 39.8 & $11-18-70$ & $\mathrm{R}$ & 5.5 & Shortsleeves & $\mathrm{NO} 3$ as $\mathrm{N}<0.2 \mathrm{mg} / \mathrm{L}, \mathrm{Cl} 6 \mathrm{mg} / \mathrm{L}, 11 / 6 / 83$, RCHD \\
\hline Re-1110 & 377SCCK & SHLE & 50 & -- & -- & - & 20 & $\mathrm{D}$ & -- \\
\hline Re-1111 & 377SCCK & SHLE & 83 & -- & $00-00-72$ & $\mathrm{R}$ & 1 & -- & Flowing $1 \mathrm{gpm}$, not potable \\
\hline Re-1112 & $112 \mathrm{ICNC}$ & SDGL & -- & 38.6 & -- & - & 80 & -- & -- \\
\hline Re-1113 & $112 \mathrm{ICNC}$ & SDGL & -- & -- & -- & - & -- & -- & Owner reports "unlimited water." soft \\
\hline Re-1118 & 111ALVM & SDGL & 0 & -- & $03-07-90$ & $\mathrm{~S}$ & 6 & Dunavin & Weekly WL measurements, March-July 1990 \\
\hline Re-1127 & 111ALVM & SDGL & 0 & -- & $05-16-46$ & $\mathrm{R}$ & -- & Danby, G & Soft, supplied school, Re-461 (abandoned) here \\
\hline Re-1128 & 377SCCK & SHLE & 71 & -- & $00-00-46$ & $\mathrm{R}$ & 190 & Hall \& Co & Well abandoned due to high iron \\
\hline Re-1129 & 111ALVM & GRVL & 0 & 19.3 & $05-00-46$ & $\mathrm{R}$ & 275 & Hall \& Co & Well abandoned due to high iron \\
\hline Re-1130 & 111ALVM & SDGL & 0 & 8.67 & $00-00-46$ & $\mathrm{R}$ & 220 & Hall \& Co & Well abandoned due to high iron \\
\hline Re-1131 & 111ALVM & SDGL & 0 & -- & $02-09-88$ & $\mathrm{~T}$ & 407 & Ferraioli & Aquifer test data on file \\
\hline
\end{tabular}


If Appendix 1. Records of wells in the Schodack-Kinderhook area, Rensselaer and Columbia Counties, N.Y. A. Wells north of $42^{\circ} 30^{\prime}$

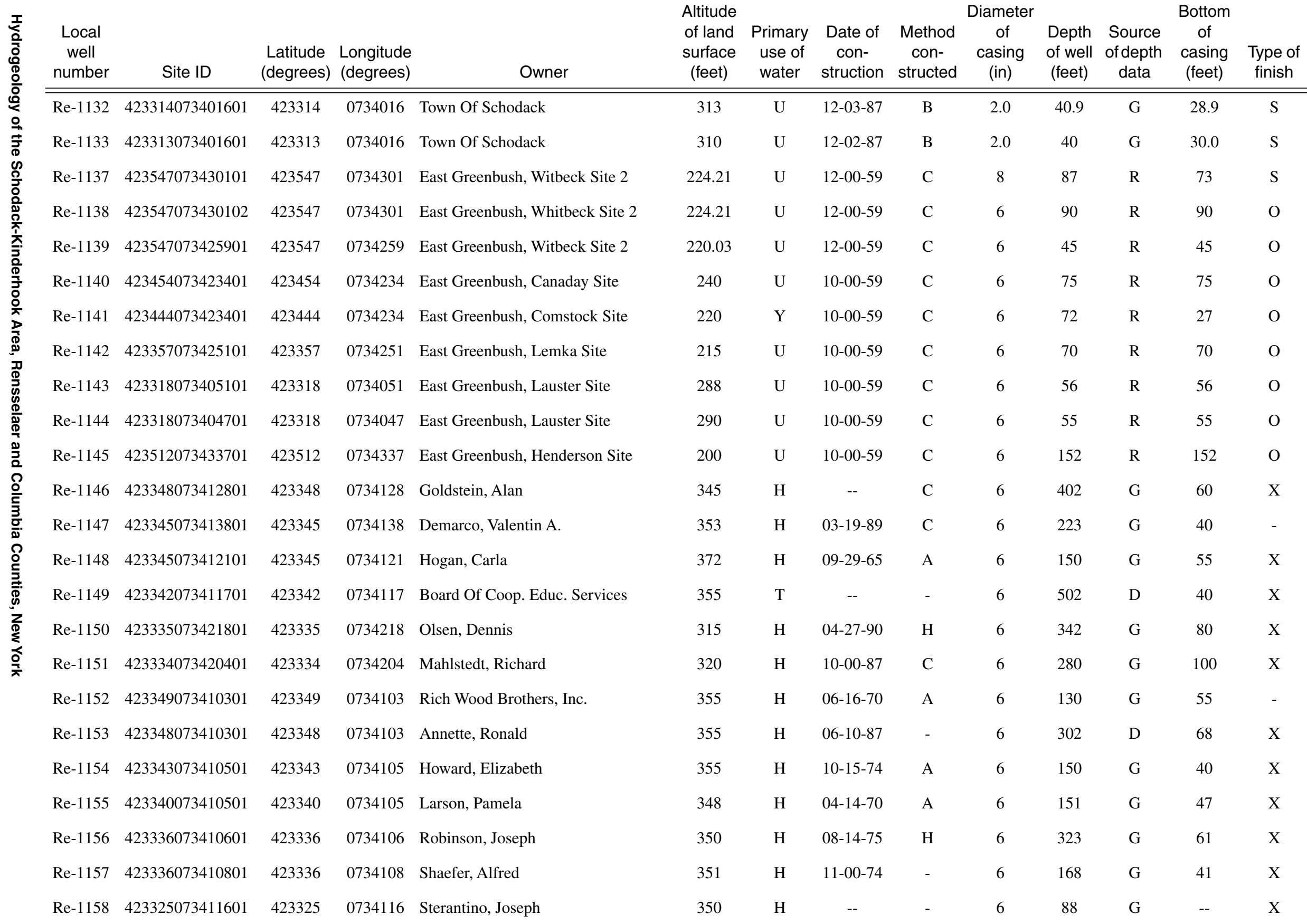


Appendix 1. Records of wells in the Schodack-Kinderhook area, Rensselaer and Columbia Counties, N.Y.

A. Wells north of $42^{\circ} 30^{\prime}$.

\begin{tabular}{|c|c|c|c|c|c|c|c|c|c|}
\hline $\begin{array}{l}\text { Local well } \\
\text { number }\end{array}$ & $\begin{array}{l}\text { Aquifer } \\
\text { code }\end{array}$ & $\begin{array}{l}\text { Lithology } \\
\text { code }\end{array}$ & $\begin{array}{l}\text { Depth } \\
\text { to top } \\
\text { (feet) }\end{array}$ & $\begin{array}{l}\text { Water } \\
\text { level } \\
\text { (feet) }\end{array}$ & $\begin{array}{c}\text { Date water } \\
\text { level } \\
\text { measured }\end{array}$ & $\begin{array}{c}\text { Method } \\
\text { water level } \\
\text { measured }\end{array}$ & $\begin{array}{l}\text { Discharge } \\
\text { (gpm) }\end{array}$ & Contractor & Remarks \\
\hline Re-1132 & 377SCCK & SHLE & 64 & 20 & $12-03-87$ & $\mathrm{~T}$ & -- & SMT, Inc & Obs well MW-1 is $126 \mathrm{ft}$ north of pumped well \\
\hline Re-1133 & 377SCCK & SHLE & 86 & 20 & $12-02-87$ & $\mathrm{~T}$ & -- & SMT, Inc & Obs well MW-2 is $27 \mathrm{ft}$ north of pumped well \\
\hline Re-1137 & 377SCCK & SHLE & 42 & 41 & $01-04-60$ & $\mathrm{R}$ & 1050 & Hall \& Co & Aquifer test in Myrick Rept \\
\hline Re-1138 & 377SCCK & SHLE & 27 & 24 & 01-04-60 & $\mathrm{R}$ & -- & Hall \& Co & DD plot and analysis in Myrick Rept \\
\hline Re-1139 & 377SCCK & SHLE & 44 & 40 & $01-04-60$ & $\mathrm{R}$ & -- & Hall \& Co & DD plot and analysis in Myrick Rept \\
\hline Re-1140 & 377SCCK & SHLE & 62 & 50 & -- & - & -- & Hall \& Co & Canaday Site test well from Myrick Report \\
\hline Re-1141 & 377SCCK & SHLE & 47 & -- & $10-00-59$ & $\mathrm{R}$ & 5 & Hall \& Co & Comstock Site test well; flows 8 in above LSD \\
\hline Re-1142 & 377SCCK & SHLE & 33 & 30 & $10-00-59$ & $\mathrm{E}$ & 10 & Hall \& Co & Lemka Site test well, flows $1.5 \mathrm{ft}$ above LSD \\
\hline Re-1143 & 377SCCK & SHLE & 80 & 33 & $10-00-59$ & $\mathrm{R}$ & 30 & Hall \& Co & Lauster Site test well from Myrick Report \\
\hline Re-1144 & 377SCCK & SHLE & 51 & 16 & $10-00-59$ & $\mathrm{R}$ & 50 & Hall \& Co & Lauster Site test well from Myrick Report \\
\hline Re-1145 & 377SCCK & SHLE & 72 & 33 & -- & - & -- & Hall \& Co & Henderson Site test well from Myrick Report \\
\hline Re-1146 & 377SCCK & SHLE & 37 & -- & -- & - & -- & -- & SWL reported at $60 \mathrm{ft}$, yield $10 \mathrm{gpm}$ \\
\hline Re-1147 & 377SCCK & SHLE & 20 & 28 & 03-19-89 & $\mathrm{R}$ & 10 & Kleinhaus, A & $\mathrm{NO} 3$ as N, $0.4 \mathrm{mg} / \mathrm{L}, \mathrm{Cl} 22 \mathrm{mg} / \mathrm{L}, 10 / 30 / 89$, RCHD \\
\hline Re-1148 & 377SCCK & SHLE & 18 & 15 & $09-29-65$ & $\mathrm{R}$ & 9 & Shortsleeves & $\mathrm{NO} 3$ as $\mathrm{N},<0.2 \mathrm{mg} / \mathrm{L}, \mathrm{Cl} 3 \mathrm{mg} / \mathrm{L}, 5 / 1 / 84, \mathrm{RCHD}$ \\
\hline Re-1149 & 377SCCK & SHLE & 25 & 25 & -- & - & -- & -- & SWL $25 \mathrm{ft}$, yield reported $6 \mathrm{gpm}$ \\
\hline Re-1150 & 377SCCK & SHLE & 12 & 18 & $04-27-90$ & $\mathrm{R}$ & 10 & Hanson & $\mathrm{NO} 3$ as $\mathrm{N},<0.2 \mathrm{mg} / \mathrm{L}, \mathrm{Cl} 52 \mathrm{mg} / \mathrm{L}, 9 / 17 / 90, \mathrm{RCHD}$ \\
\hline Re-1151 & 377SCCK & SHLE & 28 & 38 & $10-00-87$ & $\mathrm{R}$ & 5 & Eckel & $\mathrm{NO} 3$ as $\mathrm{N},<0.2 \mathrm{mg} / \mathrm{L}, \mathrm{Cl} 2 \mathrm{mg} / \mathrm{L}, 4 / 22 / 88, \mathrm{RCHD}$ \\
\hline Re-1152 & 377SCCK & SHLE & 5 & 20 & $06-17-70$ & $\mathrm{R}$ & 6.25 & Shortsleeves & $\mathrm{NO} 3$ as $\mathrm{N}, 0.04 \mathrm{mg} / \mathrm{L}, \mathrm{Cl}>60 \mathrm{mg} / \mathrm{L}, 1 / 5 / 71, \mathrm{RCHD}$ \\
\hline Re-1153 & 377SCCK & SHLE & 120 & 32 & -- & - & 10 & Hanson & $\mathrm{NO} 3$ as N, $3.8 \mathrm{mg} / \mathrm{L}, \mathrm{Cl} 51 \mathrm{mg} / \mathrm{L}, 12 / 2 / 88, \mathrm{RCHD}$ \\
\hline Re-1154 & 377SCCK & SHLE & 40 & 24 & $10-15-74$ & $\mathrm{R}$ & 5 & Hanson & Gravel $0-8 \mathrm{ft}$, till $8-20 \mathrm{ft}$, shale $20-150 \mathrm{ft}$ \\
\hline Re-1155 & 377SCCK & SHLE & 36 & 30 & 04-14-70 & $\mathrm{R}$ & 5 & Shortsleeves & $\mathrm{NO} 3$ as $\mathrm{N},<0.5 \mathrm{mg} / \mathrm{L}, \mathrm{Cl} 50 \mathrm{mg} / \mathrm{L}, 1 / 12 / 81, \mathrm{RCHD}$ \\
\hline Re-1156 & 377SCCK & SHLE & 48 & -- & $08-14-75$ & $\mathrm{R}$ & 5 & Hanson & $\mathrm{NO} 3$ as $\mathrm{N}, 0.5 \mathrm{mg} / \mathrm{L}, \mathrm{Cl} 40 \mathrm{mg} / \mathrm{L}, 11 / 12 / 75$, RCHD \\
\hline Re-1157 & 377SCCK & SHLE & 47 & 50 & $11-00-74$ & $\mathrm{R}$ & 8 & Shaver & $\mathrm{NO} 3$ as N, 3.g mg/L, Cl $16 \mathrm{mg} / \mathrm{L}, 6 / 28 / 83$, RCHD \\
\hline Re-1158 & 377SCCK & SHLE & 45 & 20 & -- & - & -- & -- & Fine grvl 0-48ft, clay $48-72 \mathrm{ft}$, shale $72-88 \mathrm{ft}$ \\
\hline
\end{tabular}


S Appendix 1. Records of wells in the Schodack-Kinderhook area, Rensselaer and Columbia Counties, N.Y. A. Wells north of $42^{\circ} 30^{\prime}$

\begin{tabular}{|c|c|c|c|c|c|c|c|c|c|c|c|c|c|}
\hline $\begin{array}{c}\text { Local } \\
\text { well } \\
\text { number }\end{array}$ & Site ID & $\begin{array}{l}\text { Latitude } \\
\text { (degrees) }\end{array}$ & $\begin{array}{r}\text { Longitude } \\
\text { (degrees) }\end{array}$ & Owner & $\begin{array}{c}\text { Altitude } \\
\text { of land } \\
\text { surface } \\
\text { (feet) }\end{array}$ & $\begin{array}{c}\text { Primary } \\
\text { use of } \\
\text { water }\end{array}$ & $\begin{array}{c}\text { Date of } \\
\text { con- } \\
\text { struction }\end{array}$ & $\begin{array}{l}\text { Method } \\
\text { con- } \\
\text { structed }\end{array}$ & $\begin{array}{l}\text { Diameter } \\
\text { of } \\
\text { casing } \\
\text { (in) }\end{array}$ & $\begin{array}{c}\text { Depth } \\
\text { of well } \\
\text { (feet) }\end{array}$ & $\begin{array}{c}\text { Source } \\
\text { of depth } \\
\text { data }\end{array}$ & $\begin{array}{c}\text { Bottom } \\
\text { of } \\
\text { casing } \\
\text { (feet) }\end{array}$ & $\begin{array}{l}\text { Type of } \\
\text { finish }\end{array}$ \\
\hline Re-1159 & 423324073411501 & 423324 & 0734115 & Kingston, Frederick & 350 & $\mathrm{H}$ & -- & - & 6 & 94 & G & -- & $\mathrm{X}$ \\
\hline Re-1160 & 423325073411301 & 423325 & 0734113 & Steen, Cahterine & 350 & $\mathrm{H}$ & -- & - & 6 & 74 & $\mathrm{G}$ & -- & $\mathrm{O}$ \\
\hline Re-1161 & 423325073411101 & 423325 & 0734111 & Steverson, Linda & 350 & $\mathrm{H}$ & -- & - & -- & 66 & $\mathrm{G}$ & -- & $\mathrm{X}$ \\
\hline Re-1162 & 423325073410601 & 423325 & 0734106 & Rowe, Norman & 350 & $\mathrm{H}$ & -- & - & -- & 106 & G & -- & $X$ \\
\hline Re-1163 & 423324073410601 & 423324 & 0734106 & Mahlstedt, David & 350 & $\mathrm{H}$ & $10-00-70$ & - & 6 & 65 & $\mathrm{G}$ & 65 & $\mathrm{O}$ \\
\hline Re-1164 & 423323073410501 & 423323 & 0734105 & Paul, Robert D. & 350 & $\mathrm{H}$ & $07-00-73$ & - & 6 & 69 & G & 69 & $\mathrm{O}$ \\
\hline Re-1165 & 423316073404301 & 423316 & 0734043 & Creekside MHP (Darwin Delappa) & 300 & $\mathrm{P}$ & -- & $\mathrm{V}$ & 1.5 & 30 & $\mathrm{G}$ & -- & $\mathrm{T}$ \\
\hline Re-1166 & 423316073404201 & 423316 & 0734042 & Creekside MHP (Darwin Delappa) & 300 & $\mathrm{P}$ & -- & $\mathrm{V}$ & 2.0 & 30 & $\mathrm{G}$ & -- & $\mathrm{T}$ \\
\hline Re-1167 & 423259073402011 & 423259 & 0734020 & Hess Service Station & 340 & $\mathrm{C}$ & 08-09-71 & - & 6 & 214 & G & 71 & $\mathrm{X}$ \\
\hline Re-1168 & 423302073421701 & 423302 & 0734217 & Herbst, Mrs. Karen & 230 & $\mathrm{H}$ & $05-25-79$ & $\mathrm{C}$ & 6 & 58 & G & 58 & $\mathrm{X}$ \\
\hline Re-1169 & 423300073421501 & 423300 & 0734215 & Calarco, David & 225 & $\mathrm{H}$ & -- & $\mathrm{C}$ & 6 & 60 & G & 60 & $\mathrm{O}$ \\
\hline Re-1170 & 423301073421201 & 423301 & 0734212 & Balt, James & 225 & $\mathrm{H}$ & -- & - & 6 & 60 & $\mathrm{G}$ & 60 & - \\
\hline Re-1171 & 423259073420901 & 423259 & 0734209 & Dorrbecker, Bruce & 215 & $\mathrm{H}$ & $06-30-77$ & A & 6 & 219 & G & 40 & - \\
\hline Re-1172 & 423244073402101 & 423244 & 0734021 & Latch, Phillip & 345 & $\mathrm{H}$ & $07-08-88$ & $\mathrm{C}$ & 6 & 228 & G & 82 & $\mathrm{X}$ \\
\hline Re-1173 & 423230073421901 & 423230 & 0734219 & Anderson, Keith & 320 & $\mathrm{H}$ & $06-23-77$ & - & 6 & 243 & $\mathrm{D}$ & 185 & $\mathrm{X}$ \\
\hline Re-1174 & 423235073414301 & 423235 & 0734143 & Doolittle, Lawrence & 315 & $\mathrm{H}$ & $04-26-71$ & - & 6 & 236 & $\mathrm{D}$ & 194 & $X$ \\
\hline Re-1175 & 423226073414001 & 423226 & 0734140 & Fuller, Jeffery & 330 & $\mathrm{H}$ & $04-13-89$ & - & 6 & 223 & $\mathrm{D}$ & 175 & $\mathrm{X}$ \\
\hline Re-1176 & 423223073404201 & 423223 & 0734042 & Collier, John & 345 & $\mathrm{H}$ & $11-15-77$ & - & 6 & 125 & - & 41 & $X$ \\
\hline Re-1177 & 423222073400301 & 423222 & 0734003 & Hempstead, Sandra & 440 & $\mathrm{H}$ & $10-08-78$ & - & 6 & 159 & $\mathrm{G}$ & 40 & $\mathrm{X}$ \\
\hline Re-1178 & 423203073404301 & 423203 & 0734043 & House Of Praise Ministries & 355 & $\mathrm{~T}$ & $08-31-87$ & - & 6 & 420 & $\mathrm{G}$ & 39 & $\mathrm{X}$ \\
\hline Re-1179 & 423158073425001 & 423158 & 0734250 & Crowley, P. \& M. & 240 & $\mathrm{H}$ & -- & $\mathrm{C}$ & 6 & 145 & $\mathrm{G}$ & 38 & - \\
\hline Re-1180 & 423157073424901 & 423157 & 0734249 & Bult Subdivision & 238 & $\mathrm{H}$ & $10-00-86$ & $\mathrm{H}$ & 6 & 200 & G & 43.5 & $\mathrm{X}$ \\
\hline Re-1181 & 423153073425401 & 423153 & 0734254 & Isabelle, Fernand & 255 & $\mathrm{H}$ & $08-00-73$ & - & 6 & 240 & $\mathrm{G}$ & 39 & - \\
\hline Re-1182 & 423150073425401 & 423150 & 0734254 & Beerle & 260 & $\mathrm{H}$ & 09-09-86 & $\mathrm{H}$ & 6 & 200 & G & 41.5 & $X$ \\
\hline
\end{tabular}


Appendix 1. Records of wells in the Schodack-Kinderhook area, Rensselaer and Columbia Counties, N.Y.

A. Wells north of $42^{\circ} 30^{\prime}$.

\begin{tabular}{|c|c|c|c|c|c|c|c|c|c|}
\hline $\begin{array}{l}\text { Local well } \\
\text { number }\end{array}$ & $\begin{array}{l}\text { Aquifer } \\
\text { code }\end{array}$ & $\begin{array}{l}\text { Lithology } \\
\text { code }\end{array}$ & $\begin{array}{l}\text { Depth } \\
\text { to top } \\
\text { (feet) }\end{array}$ & $\begin{array}{l}\text { Water } \\
\text { level } \\
\text { (feet) }\end{array}$ & $\begin{array}{c}\text { Date water } \\
\text { level } \\
\text { measured }\end{array}$ & $\begin{array}{c}\text { Method } \\
\text { water level } \\
\text { measured }\end{array}$ & $\begin{array}{l}\text { Discharge } \\
\text { (gpm) }\end{array}$ & Contractor & Remarks \\
\hline Re-1159 & 377SCCK & SHLE & 55 & -- & -- & - & -- & -- & Grvl 0-18 ft, fine sand $18-65 \mathrm{ft}$, shale $65-94 \mathrm{ft}$ \\
\hline Re-1160 & 112GLCD & SAND & 50 & 20 & $11-19-92$ & $S$ & -- & -- & Grvl 0-20 ft, fine sand $20-55 \mathrm{ft}$, fine gravel $55-74 \mathrm{ft}$ \\
\hline Re-1161 & -- & -- & -- & -- & -- & - & -- & -- & Grvl 0-25ft, sand $25-50 \mathrm{ft}$, shale $50-66 \mathrm{ft}$ \\
\hline Re-1162 & 377SCCK & SHLE & -- & 40 & -- & - & -- & -- & Grvl 0-30 ft, till $30-83 \mathrm{ft}$, shale $83-106 \mathrm{ft}$ \\
\hline Re-1163 & 377SCCK & SHLE & -- & -- & $11-12-92$ & S & 20 & Shaver & $\mathrm{NO} 3$ as N, $3.0 \mathrm{mg} / \mathrm{L}, \mathrm{Cl} 13 \mathrm{mg} / \mathrm{L}, 11 / 28 / 79$, RCHD \\
\hline Re-1164 & 377SCCK & SHLE & -- & -- & -- & - & 8 & Shaver & $\mathrm{NO} 3$ as N, $0.2 \mathrm{mg} / \mathrm{L}, \mathrm{Cl} 4 \mathrm{mg} / \mathrm{L}, 9 / 17 / 73, \mathrm{RCHD}$ \\
\hline Re-1165 & -- & -- & -- & -- & -- & - & 7.5 & -- & NO3 as N, $0.92 \mathrm{mg} / \mathrm{L}, 12 / 23 / 81, \mathrm{RCHD}$ \\
\hline Re-1166 & 112GLCD & GRVL & 20 & -- & -- & - & 7.5 & -- & -- \\
\hline Re-1167 & 364NMKL & SHLE & 100 & 45 & -- & - & 8.0 & Hanson & Second well at this location \\
\hline Re-1168 & 112GLCD & SDGL & -- & 82 & $11-12-92$ & S & 25 & D Horton & $\mathrm{NO} 3$ as $\mathrm{N},<0.5 \mathrm{mg} / \mathrm{L}, \mathrm{Cl} 14 \mathrm{mg} / \mathrm{L}, 7 / 12 / 79, \mathrm{RCHD}$ \\
\hline Re-1169 & 112LAKE & SAND & 0 & -- & $11-12-92$ & S & -- & Kleinhaus & NO3 as $\mathrm{N},<0.2 \mathrm{mg} / \mathrm{L}, \mathrm{Cl} 141 \mathrm{mg} / \mathrm{L}, 12 / 26 / 85, \mathrm{RCHD}$ \\
\hline Re-1170 & -- & -- & -- & -- & -- & - & 15 & Eckel & $\mathrm{NO} 3$ as $\mathrm{N},<0.2 \mathrm{mg} / \mathrm{L}, \mathrm{Cl} 5 \mathrm{mg} / \mathrm{L}, 3 / 31 / 87, \mathrm{RCHD}$ \\
\hline Re-1171 & 377SCCK & SHLE & 32 & 10 & $06-30-77$ & $\mathrm{R}$ & 5 & Hanson & $\mathrm{NO} 3$ as $\mathrm{N},<0.5 \mathrm{mg} / \mathrm{L}, \mathrm{Cl} 8 \mathrm{mg} / \mathrm{L}, 5 / 10 / 78, \mathrm{RCHD}$ \\
\hline Re-1172 & 377SCCK & SHLE & 82 & 45 & $07-08-88$ & $\mathrm{R}$ & 30 & Jeff Smith & $0-82 \mathrm{ft}$ till w/gravel seams, $82-228 \mathrm{ft}$ shale \\
\hline Re-1173 & 364NMKL & SHLE & 168 & 35 & $06-23-77$ & $\mathrm{R}$ & 4 & Hanson & $\mathrm{NO} 3$ as $\mathrm{N},<0.2 \mathrm{mg} / \mathrm{L}, \mathrm{Cl} 12 \mathrm{mg} / \mathrm{L}, 11 / 28 / 89, \mathrm{RCHD}$ \\
\hline Re-1174 & 377SCCK & SHLE & 194 & 96 & $04-26-71$ & $\mathrm{R}$ & 10 & Shortsleeves & $\mathrm{NO} 3$ as $\mathrm{N},<0.2 \mathrm{mg} / \mathrm{L}, \mathrm{Cl} 21 \mathrm{mg} / \mathrm{L}, 9 / 15 / 86, \mathrm{RCHD}$ \\
\hline Re-1175 & 377SCCK & SHLE & 170 & 40 & 04-13-89 & $\mathrm{R}$ & 15 & Hanson & $\mathrm{NO} 3$ as $\mathrm{N},<0.2 \mathrm{mg} / \mathrm{L}, \mathrm{Cl} 85 \mathrm{mg} / \mathrm{L}, 9 / 29 / 89, \mathrm{RCHD}$ \\
\hline Re-1176 & 377SCCK & SHLE & 15 & -- & -- & - & 5 & Gordon Goold & $\mathrm{NO} 3$ as $\mathrm{N}, 5.0 \mathrm{mg} / \mathrm{L}, \mathrm{Cl} 76 \mathrm{mg} / \mathrm{L}, 10 / 4 / 77, \mathrm{RCHD}$ \\
\hline Re-1177 & 377SCCK & SHLE & 15 & -- & -- & - & 5 & Hanson & $\mathrm{NO} 3$ as $\mathrm{N},<0.2 \mathrm{mg} / \mathrm{L}, \mathrm{Cl} 6 \mathrm{mg} / \mathrm{L}, 7 / 24 / 84, \mathrm{RCHD}$ \\
\hline Re-1178 & 377SCCK & SHLE & 12 & -- & -- & - & 5 & Gordon Goold & Two wells at this location \\
\hline Re-1179 & 364NMKL & SHLE & 32 & 20 & $11-18-61$ & $\mathrm{R}$ & 4 & Laureny, $\mathrm{Hr}$ & $\mathrm{NO} 3$ as $\mathrm{N},<0.2 \mathrm{mg} / \mathrm{L}, \mathrm{Cl} 13 \mathrm{mg} / \mathrm{L}, 7 / 13 / 84, \mathrm{RCHD}$ \\
\hline Re-1180 & 364NMKL & SHLE & 40 & 35 & $10-00-86$ & $\mathrm{R}$ & 5 & -- & $\mathrm{NO} 3$ as $\mathrm{N},<0.2 \mathrm{mg} / \mathrm{L}, \mathrm{Cl} 6 \mathrm{mg} / \mathrm{L}, 3 / 5 / 87, \mathrm{RCHD}$ \\
\hline Re-1181 & 364NMKL & SHLE & 12 & 26 & $08-00-73$ & $\mathrm{R}$ & 6 & Shaver & Till $0-12 \mathrm{ft}$, shale $12-240 \mathrm{ft}$ \\
\hline Re-1182 & 364NMKL & SHLE & 35 & -- & -- & - & -- & Eckel, RB & $\mathrm{NO} 3$ as $\mathrm{N},<0.2 \mathrm{mg} / \mathrm{L}, \mathrm{Cl} 69 \mathrm{mg} / \mathrm{L}, 8 / 6 / 87, \mathrm{RCHD}$ \\
\hline
\end{tabular}


II Appendix 1. Records of wells in the Schodack-Kinderhook area, Rensselaer and Columbia Counties, N.Y. A. Wells north of $42^{\circ} 30^{\prime}$

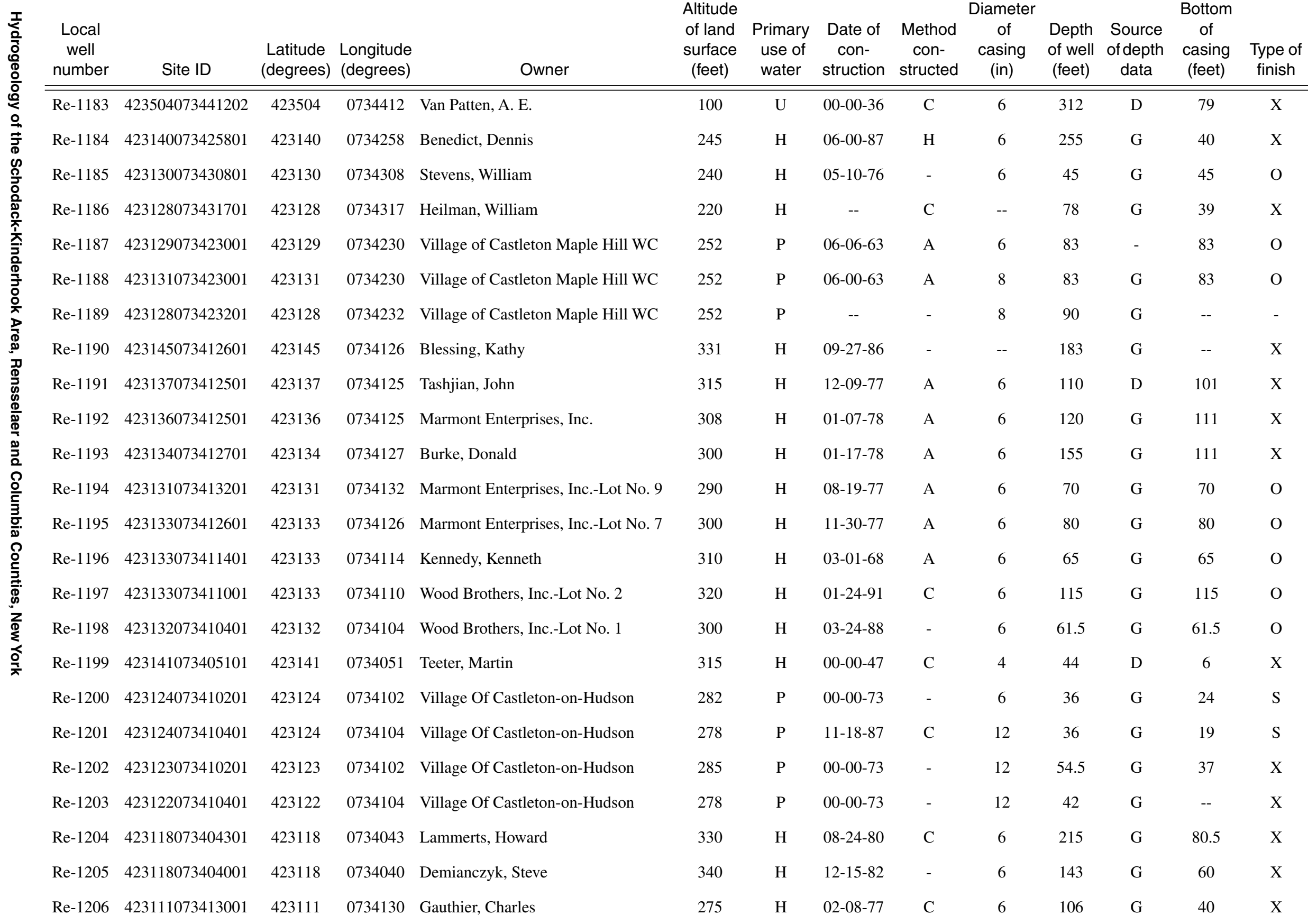


Appendix 1. Records of wells in the Schodack-Kinderhook area, Rensselaer and Columbia Counties, N.Y.

A. Wells north of $42^{\circ} 30^{\prime}$.

\begin{tabular}{|c|c|c|c|c|c|c|c|c|c|}
\hline $\begin{array}{l}\text { Local well } \\
\text { number }\end{array}$ & $\begin{array}{l}\text { Aquifer } \\
\text { code }\end{array}$ & $\begin{array}{l}\text { Lithology } \\
\text { code }\end{array}$ & $\begin{array}{l}\text { Depth } \\
\text { to top } \\
\text { (feet) }\end{array}$ & $\begin{array}{l}\text { Water } \\
\text { level } \\
\text { (feet) }\end{array}$ & $\begin{array}{c}\text { Date water } \\
\text { level } \\
\text { measured }\end{array}$ & $\begin{array}{c}\text { Method } \\
\text { water level } \\
\text { measured }\end{array}$ & $\begin{array}{l}\text { Discharge } \\
\quad(g p m)\end{array}$ & Contractor & Remarks \\
\hline Re-1183 & 364NMKL & $\mathrm{Cl}$ AY & 0 & -- & -- & - & -- & Hall \& Co & Dry well, abandoned. Location approximate \\
\hline Re-1184 & 364NMKL & SHLE & 20 & -- & -- & - & 10 & Eckel, RB & $\mathrm{NO} 3$ as $\mathrm{N},<0.2 \mathrm{mg} / \mathrm{L}, \mathrm{Cl} 26 \mathrm{mg} / \mathrm{L}, 7 / 23 / 87, \mathrm{RCHD}$ \\
\hline Re-1185 & 112GLCD & GRVL & 25 & -- & -- & - & 8 & Kleinhans, A & $\mathrm{NO} 3$ as $\mathrm{N},<0.5 \mathrm{mg} / \mathrm{L}, \mathrm{Cl} 13 \mathrm{mg} / \mathrm{L}, 11 / 8 / 78, \mathrm{RCHD}$ \\
\hline Re-1186 & 364NMKL & SHLE & 28 & -- & -- & - & -- & -- & SWL $15 \mathrm{ft}$, yield $30 \mathrm{gpm}$ \\
\hline Re-1187 & 112GLCD & GRVL & 76 & 17 & $06-00-63$ & $\mathrm{R}$ & 150 & Shortsleeves & Wells $1 \& 2$ are standby, well 3 is online \\
\hline Re-1188 & 112GLCD & GRVL & -- & 17 & $06-00-63$ & $\mathrm{R}$ & 50 & Shortsleeves & Wells $1 \& 2$ are standby, well 3 is online \\
\hline Re-1189 & 112GLCD & -- & -- & -- & -- & - & 275 & -- & Primary well. Wells $1 \& 2$ are standby wells \\
\hline Re-1190 & 377SCCK & SHLE & 90 & -- & -- & - & 8 & Kruyl? & $\mathrm{NO} 3$ as $\mathrm{N},<0.2 \mathrm{mg} / \mathrm{L}, \mathrm{Cl} 8 \mathrm{mg} / \mathrm{L}, 10 / 14 / 86, \mathrm{RCHD}$ \\
\hline Re-1191 & 377SCCK & SHLE & 98 & 38 & $12-09-77$ & $\mathrm{R}$ & 8 & Hanson & $\mathrm{NO} 3$ as $\mathrm{N},<0.5 \mathrm{mg} / \mathrm{L}, \mathrm{Cl} 9 \mathrm{mg} / \mathrm{L}, 2 / 8 / 78, \mathrm{RCHD}$ \\
\hline Re-1192 & 377SCCK & SHLE & 105 & 40 & $01-07-78$ & $\mathrm{R}$ & 10 & Hanson & -- \\
\hline Re-1193 & 377 SCCK & SHLE & 103 & 42 & $01-17-78$ & $\mathrm{R}$ & 20 & Hanson & $\mathrm{NO} 3$ as $\mathrm{N},<0.3 \mathrm{mg} / \mathrm{L}, \mathrm{Cl} 23 \mathrm{mg} / \mathrm{L}, 6 / 17 / 86, \mathrm{RCHD}$ \\
\hline Re-1194 & $112 \mathrm{ICNC}$ & SDGL & -- & 20 & 08-19-77 & $\mathrm{R}$ & 15 & Hanson & $\mathrm{NO} 3$ as $\mathrm{N},<0.5 \mathrm{mg} / \mathrm{L}, \mathrm{Cl} 27 \mathrm{mg} / \mathrm{L}, 11 / 3 / 77, \mathrm{RCHD}$ \\
\hline Re-1195 & $112 \mathrm{ICNC}$ & SDGL & -- & 25 & $11-30-77$ & $\mathrm{R}$ & 10 & Hanson & $\mathrm{NO} 3$ as $\mathrm{N},<0.5 \mathrm{mg} / \mathrm{L}, \mathrm{Cl} 5 \mathrm{mg} / \mathrm{L}, 1 / 11 / 78, \mathrm{RCHD}$ \\
\hline Re-1196 & $112 \mathrm{ICNC}$ & SDGL & 0 & 47 & $03-01-68$ & $\mathrm{R}$ & 20 & Shortsleeves & $\mathrm{NO} 3$ as $\mathrm{N},<1.2 \mathrm{mg} / \mathrm{L}, \mathrm{Cl} 60 \mathrm{mg} / \mathrm{L}, 2 / 21 / 69, \mathrm{RCHD}$ \\
\hline Re-1197 & $112 \mathrm{ICNC}$ & SDGL & 0 & 26.4 & $11-19-92$ & $\mathrm{~S}$ & 20 & Eckel & $\mathrm{NO} 3$ as $\mathrm{N},<0.6 \mathrm{mg} / \mathrm{L}, \mathrm{Cl} 47 \mathrm{mg} / \mathrm{L}, 1 / 24 / 91, \mathrm{RCHD}$ \\
\hline Re-1198 & $112 \mathrm{ICNC}$ & SDGL & 0 & 20 & $03-24-88$ & $\mathrm{R}$ & 12 & Hanson & $\mathrm{NO} 3$ as $\mathrm{N},<0.2 \mathrm{mg} / \mathrm{L}, \mathrm{Cl} 18 \mathrm{mg} / \mathrm{L}, 12 / 5 / 91, \mathrm{RCHD}$ \\
\hline Re-1199 & 377SCCK & SHLE & 6 & -- & -- & - & 10 & Shaver & $\mathrm{NO} 3$ as $\mathrm{N},<4.0 \mathrm{mg} / \mathrm{L}, \mathrm{Cl} 13 \mathrm{mg} / \mathrm{L}, 6 / 16 / 69, \mathrm{RCHD}$ \\
\hline Re-1200 & $112 \mathrm{ICNC}$ & SDGL & 0 & -- & -- & - & 53 & -- & Former NYSDOT well F \\
\hline Re-1201 & $112 \mathrm{ICNC}$ & SDGL & 3 & -- & -- & - & 276 & Alan \& Brent & Former NYSDOT well E-1 \\
\hline Re-1202 & 377SCCK & SHLE & 37 & -- & -- & - & 53 & -- & Former NYSDOT well G \\
\hline Re-1203 & 377SCCK & SHLE & -- & -- & -- & - & 53 & -- & Former NYSDOT well E \\
\hline Re-1204 & 377SCCK & SHLE & 79 & 51 & $08-24-80$ & $\mathrm{R}$ & 10 & John Kindley & $\mathrm{NO} 3$ as $\mathrm{N}, 0.5 \mathrm{mg} / \mathrm{L}, \mathrm{Cl} 6 \mathrm{mg} / \mathrm{L}, 9 / 17 / 80, \mathrm{RCHD}$ \\
\hline Re-1205 & 377SCCK & SHLE & 60 & -- & -- & - & 4 & Eckel & -- \\
\hline Re-1206 & 377SCCK & SHLE & 25 & -- & -- & - & 5.5 & Salisbury & -- \\
\hline
\end{tabular}


II Appendix 1. Records of wells in the Schodack-Kinderhook area, Rensselaer and Columbia Counties, N.Y. A. Wells north of $42^{\circ} 30^{\prime}$

\begin{tabular}{|c|c|c|c|c|c|c|c|c|c|c|c|c|c|}
\hline $\begin{array}{l}\text { Local } \\
\text { well } \\
\text { number }\end{array}$ & Site ID & $\begin{array}{l}\text { Latitude } \\
\text { (degrees) }\end{array}$ & $\begin{array}{r}\text { Longitude } \\
\text { (degrees) }\end{array}$ & Owner & $\begin{array}{l}\text { Altitude } \\
\text { of land } \\
\text { surface } \\
\text { (feet) }\end{array}$ & $\begin{array}{c}\text { Primary } \\
\text { use of } \\
\text { water }\end{array}$ & $\begin{array}{c}\text { Date of } \\
\text { con- } \\
\text { struction }\end{array}$ & $\begin{array}{l}\text { Method } \\
\text { con- } \\
\text { structed }\end{array}$ & $\begin{array}{l}\text { Diameter } \\
\text { of } \\
\text { casing } \\
\text { (in) }\end{array}$ & $\begin{array}{c}\text { Depth } \\
\text { of well } \\
\text { (feet) }\end{array}$ & $\begin{array}{c}\text { Source } \\
\text { of depth } \\
\text { data }\end{array}$ & $\begin{array}{l}\text { Bottom } \\
\text { of } \\
\text { casing } \\
\text { (feet) }\end{array}$ & $\begin{array}{l}\text { Type of } \\
\text { finish }\end{array}$ \\
\hline Re-1207 & 423114073410701 & 423114 & 0734107 & Isabelle, Serge & 320 & $\mathrm{H}$ & $04-02-87$ & $\mathrm{C}$ & 6 & 63 & G & 63 & $\mathrm{O}$ \\
\hline Re-1208 & 423108073403901 & 423108 & 0734039 & Pinehaven MHP & 340 & $\mathrm{P}$ & $12-09-65$ & $\mathrm{C}$ & 8 & 53 & G & 44 & $\mathrm{X}$ \\
\hline Re-1209 & 423104073404601 & 423104 & 0734046 & Pinehaven MHP & 377 & $\mathrm{P}$ & $10-00-78$ & - & 6 & 176 & $\mathrm{G}$ & -- & $\mathrm{X}$ \\
\hline Re-1210 & 423104073403801 & 423104 & 0734038 & Pinehaven MHP & 328 & $\mathrm{P}$ & $06-28-88$ & $\mathrm{H}$ & 6 & 52 & G & 39 & $S$ \\
\hline Re-1211 & 423105073403701 & 423105 & 0734037 & Pinehaven MHP & 325 & $\mathrm{P}$ & $06-23-84$ & $\mathrm{H}$ & 6 & 50.5 & $\mathrm{G}$ & 42 & $S$ \\
\hline Re-1212 & 423122073395601 & 423122 & 0733956 & Kelly, Stephen & 405 & $\mathrm{H}$ & $04-10-91$ & $\mathrm{C}$ & 6 & 25 & $\mathrm{G}$ & 49.5 & $\mathrm{X}$ \\
\hline Re-1213 & 423114073394701 & 423114 & 0733947 & Sandez, Daniel & 415 & $\mathrm{H}$ & $08-00-85$ & $\mathrm{H}$ & 6 & 180 & $\mathrm{D}$ & 46.5 & $\mathrm{X}$ \\
\hline Re-1214 & 423055073410301 & 423055 & 0734103 & Schodack Water Dist. 1 - Clearview & 295 & $\mathrm{P}$ & $04-10-62$ & - & 8 & 41 & $\mathrm{G}$ & -- & $S$ \\
\hline Re-1215 & 423054073410201 & 423054 & 0734102 & Schodack Water Dist. 1 - Clearview & 295 & $\mathrm{P}$ & $11-00-63$ & - & 8 & 49 & G & 39 & $S$ \\
\hline Re-1216 & 423055073410101 & 423055 & 0734101 & Schodack Water Dist. 1 - Clearview & 295 & $\mathrm{P}$ & $06-18-65$ & - & 10 & 48 & G & -- & $S$ \\
\hline Re-1217 & 423057073413501 & 423057 & 0734135 & Garcia, Roger & 265 & $\mathrm{H}$ & $05-00-86$ & $\mathrm{C}$ & 6 & 110 & G & 65 & $\mathrm{X}$ \\
\hline Re-1218 & 423050073413701 & 423050 & 0734137 & Defiglio, Vincent & 265 & $\mathrm{H}$ & -- & $\mathrm{C}$ & 6 & 50 & $\mathrm{G}$ & 50 & $\mathrm{O}$ \\
\hline Re-1219 & 423041073422001 & 423041 & 0734220 & Mesick, Geraldine & 270 & $\mathrm{H}$ & $07-11-90$ & $\mathrm{C}$ & 6 & 290 & G & 40 & $\mathrm{X}$ \\
\hline Re-1220 & 423047073423101 & 423047 & 0734231 & Morrell, Scott & 250 & $\mathrm{H}$ & $11-17-82$ & $\mathrm{H}$ & 6 & 300 & G & 106 & $X$ \\
\hline Re-1221 & 423044073424801 & 423044 & 0734248 & Harris, Donald & 245 & $\mathrm{H}$ & $05-10-81$ & - & 6 & 85 & $\mathrm{G}$ & 85 & $\mathrm{O}$ \\
\hline Re-1222 & 423043073425001 & 423043 & 0734250 & Swartz, Arnold & 240 & $\mathrm{H}$ & $07-00-90$ & $\mathrm{H}$ & 6 & 204 & $\mathrm{G}$ & 40 & $\mathrm{X}$ \\
\hline Re-1223 & 423046073425901 & 423046 & 0734259 & Olsen, Claude & 255 & $\mathrm{H}$ & $03-30-71$ & $\mathrm{C}$ & 6 & 80 & $\mathrm{G}$ & 25 & $X$ \\
\hline Re-1224 & 423042073425601 & 423042 & 0734256 & Palmer, Francis & 240 & $\mathrm{H}$ & $08-30-81$ & $\mathrm{C}$ & 6 & 80 & G & 40 & $\mathrm{X}$ \\
\hline Re-1225 & 423024073423001 & 423024 & 0734230 & Stewart, Michael & 225 & $\mathrm{H}$ & -- & $\mathrm{C}$ & 6 & 263 & $\mathrm{G}$ & 40 & $\mathrm{X}$ \\
\hline Re-1226 & 423022073422701 & 423022 & 0734227 & Overbaugh, Robert & 245 & $\mathrm{H}$ & -- & $\mathrm{C}$ & 6 & 223 & $\mathrm{G}$ & 48 & $\mathrm{X}$ \\
\hline Re-1227 & 423012073423801 & 423012 & 0734238 & Cornerstone Homes, Inc. & 227 & $\mathrm{H}$ & $05-30-90$ & $\mathrm{H}$ & 6 & 482 & G & 58 & - \\
\hline Re-1228 & 423012073423601 & 423012 & 0734236 & Busdiecker, John & 230 & $\mathrm{H}$ & $05-02-90$ & A & 6 & 502 & G & 60 & $X$ \\
\hline Re-1229 & 423011073431701 & 423011 & 0734317 & Joyner, John & 215 & $\mathrm{H}$ & $05-04-91$ & - & 6 & 385 & G & 126 & $\mathrm{X}$ \\
\hline Re-1230 & 423026073411401 & 423026 & 0734114 & New York State Thruway Authority & 335 & $\mathrm{P}$ & $05-00-69$ & - & 6 & 250 & G & -- & $X$ \\
\hline
\end{tabular}


Appendix 1. Records of wells in the Schodack-Kinderhook area, Rensselaer and Columbia Counties, N.Y.

A. Wells north of $42^{\circ} 30^{\prime}$.

\begin{tabular}{|c|c|c|c|c|c|c|c|c|c|}
\hline $\begin{array}{l}\text { Local well } \\
\text { number }\end{array}$ & $\begin{array}{l}\text { Aquifer } \\
\text { code }\end{array}$ & $\begin{array}{l}\text { Lithology } \\
\text { code }\end{array}$ & $\begin{array}{l}\text { Depth } \\
\text { to top } \\
\text { (feet) }\end{array}$ & $\begin{array}{l}\text { Water } \\
\text { level } \\
\text { (feet) }\end{array}$ & $\begin{array}{c}\text { Date water } \\
\text { level } \\
\text { measured }\end{array}$ & $\begin{array}{c}\text { Method } \\
\text { water level } \\
\text { measured }\end{array}$ & $\begin{array}{l}\text { Discharge } \\
\text { (gpm) }\end{array}$ & Contractor & Remarks \\
\hline Re-1207 & $112 \mathrm{ICNC}$ & SDGL & 0 & -- & -- & - & 10 & Eckel & $\mathrm{NO} 3$ as N, $0.5 \mathrm{mg} / \mathrm{L}, \mathrm{Cl} 13 \mathrm{mg} / \mathrm{L}, 6 / 1 / 87, \mathrm{RCHD}$ \\
\hline Re-1208 & $112 \mathrm{ICNC}$ & SDGL & 34 & 21 & $12-09-65$ & $\mathrm{R}$ & 110 & Gordon Goold & Removed from service 1984 \\
\hline Re-1209 & 377SCCK & SHLE & -- & -- & -- & - & 120 & -- & Bedrock well \\
\hline Re-1210 & 112OTSH & SDGL & 0 & 19 & $06-28-88$ & $\mathrm{R}$ & 100 & Gordon Goold & $12 \mathrm{ft}$ of $16-\mathrm{ft}$ screen exposed \\
\hline $\operatorname{Re}-1211$ & 112OTSH & SDGL & 0 & 8 & $06-23-84$ & $\mathrm{R}$ & 120 & Gordon Goold & $8 \mathrm{ft}$ of $10-\mathrm{ft}$ screen exposed \\
\hline Re-1212 & 377SCCK & SHLE & 40 & 20 & 04-10-91 & $\mathrm{R}$ & 8 & Adam Hacker & $\mathrm{NO} 3$ as $\mathrm{N},<0.2 \mathrm{mg} / \mathrm{L}, \mathrm{Cl} 8 \mathrm{mg} / \mathrm{L}, 3 / 26 / 91, \mathrm{RCHD}$ \\
\hline $\operatorname{Re}-1213$ & 377SCCK & SHLE & 5 & -- & -- & - & 5 & -- & -- \\
\hline Re-1214 & $112 \mathrm{ICNC}$ & SDGL & 21 & 24.8 & $07-12-86$ & S & 450 & Gordon Goold & Aquifer test by driller $7 / 12 / 86$ \\
\hline Re-1215 & $112 \mathrm{ICNC}$ & SDGL & -- & 24.8 & $07-10-86$ & $\mathrm{R}$ & 150 & Gordon Goold & Aquifer test by driller $7 / 10 / 86$ \\
\hline $\operatorname{Re}-1216$ & $112 \mathrm{ICNC}$ & SDGL & 37 & -- & -- & - & 120 & Gordon Goold & Aquifer test by driller $7 / 8 / 86$ \\
\hline Re-1217 & 377SCCK & SHLE & 65 & 12 & $05-00-86$ & $\mathrm{R}$ & 6 & Eckel & $\mathrm{NO} 3$ as $\mathrm{N},<0.2 \mathrm{mg} / \mathrm{L}, \mathrm{Cl} 17 \mathrm{mg} / \mathrm{L}, 7 / 31 / 86, \mathrm{RCHD}$ \\
\hline Re-1218 & 112GLCD & SAND & 0 & -- & -- & - & -- & Kleinhaus & -- \\
\hline Re-1219 & 377SCCK & SHLE & 12 & 30 & $07-11-90$ & $\mathrm{R}$ & 5 & Jeff Smith & $\mathrm{NO} 3$ as $\mathrm{N}, 7.0 \mathrm{mg} / \mathrm{L}, \mathrm{Cl} 115 \mathrm{mg} / \mathrm{L}, 9 / 17 / 90, \mathrm{RCHD}$ \\
\hline $\operatorname{Re}-1220$ & 364NMKL & SHLE & -- & 45 & $11-17-82$ & $\mathrm{R}$ & 3 & Hanson & -- \\
\hline Re-1221 & 112GLCD & SDGL & 48 & -- & -- & - & 10 & Eckel & $\mathrm{NO} 3$ as $\mathrm{N},<0.2 \mathrm{mg} / \mathrm{L}, \mathrm{Cl} 95 \mathrm{mg} / \mathrm{L}, 11 / 23 / 81, \mathrm{RCHD}$ \\
\hline Re-1222 & 364NMKL & SHLE & 15 & 18 & $07-00-90$ & $\mathrm{R}$ & 5 & Eckel & $\mathrm{NO} 3$ as $\mathrm{N},>0.2 \mathrm{mg} / \mathrm{L}, \mathrm{Cl} 13 \mathrm{mg} / \mathrm{L}, 10 / 17 / 90, \mathrm{RCHD}$ \\
\hline Re-1223 & 364NMKL & SHLE & 0 & -- & -- & - & 8 & Kleinhaus, A & -- \\
\hline Re-1224 & 364NMKL & SHLE & 10 & -- & -- & - & 7 & Eckel & $\mathrm{NO} 3$ as N, $0.8 \mathrm{mg} / \mathrm{L}, \mathrm{Cl} 53 \mathrm{mg} / \mathrm{L}, 12 / 4 / 81$, RCHD \\
\hline Re-1225 & 377SCCK & SHLE & 35 & 30 & $04-30-84$ & $\mathrm{R}$ & 2 & Kinl & $\mathrm{NO} 3$ as $\mathrm{N},<0.2 \mathrm{mg} / \mathrm{L}, \mathrm{Cl} 24 \mathrm{mg} / \mathrm{L}, 9 / 21 / 87, \mathrm{RCHD}$ \\
\hline Re-1226 & 377SCCK & SHLE & 45 & -- & -- & - & -- & -- & SWL $40 \mathrm{ft}$ when drilled, yield $10 \mathrm{gpm}$ \\
\hline Re-1227 & 377SCCK & SHLE & 55 & 27.2 & $05-03-90$ & $\mathrm{R}$ & 6 & Hanson & -- \\
\hline Re-1228 & 377SCCK & SHLE & 57 & 28.7 & $05-02-90$ & $\mathrm{R}$ & 5 & Hanson & $\mathrm{NO} 3$ as N, $0.5 \mathrm{mg} / \mathrm{L}, \mathrm{Cl} 15 \mathrm{mg} / \mathrm{L}, 5 / 20 / 90, \mathrm{RCHD}$ \\
\hline Re-1229 & 364NMKL & SHLE & 126 & 90 & $05-04-91$ & $\mathrm{R}$ & 5 & -- & $\mathrm{NO} 3$ as $\mathrm{N},<0.2 \mathrm{mg} / \mathrm{L}, \mathrm{Cl} 42 \mathrm{mg} / \mathrm{L}, 6 / 6 / 91, \mathrm{RCHD}$ \\
\hline $\operatorname{Re}-1230$ & 377SCCK & SHLE & 42 & 80 & 06-03-69 & $\mathrm{R}$ & 12 & Hanson & Pumping test data \\
\hline
\end{tabular}


(I) Appendix 1. Records of wells in the Schodack-Kinderhook area, Rensselaer and Columbia Counties, N.Y. A. Wells north of $42^{\circ} 30^{\prime}$

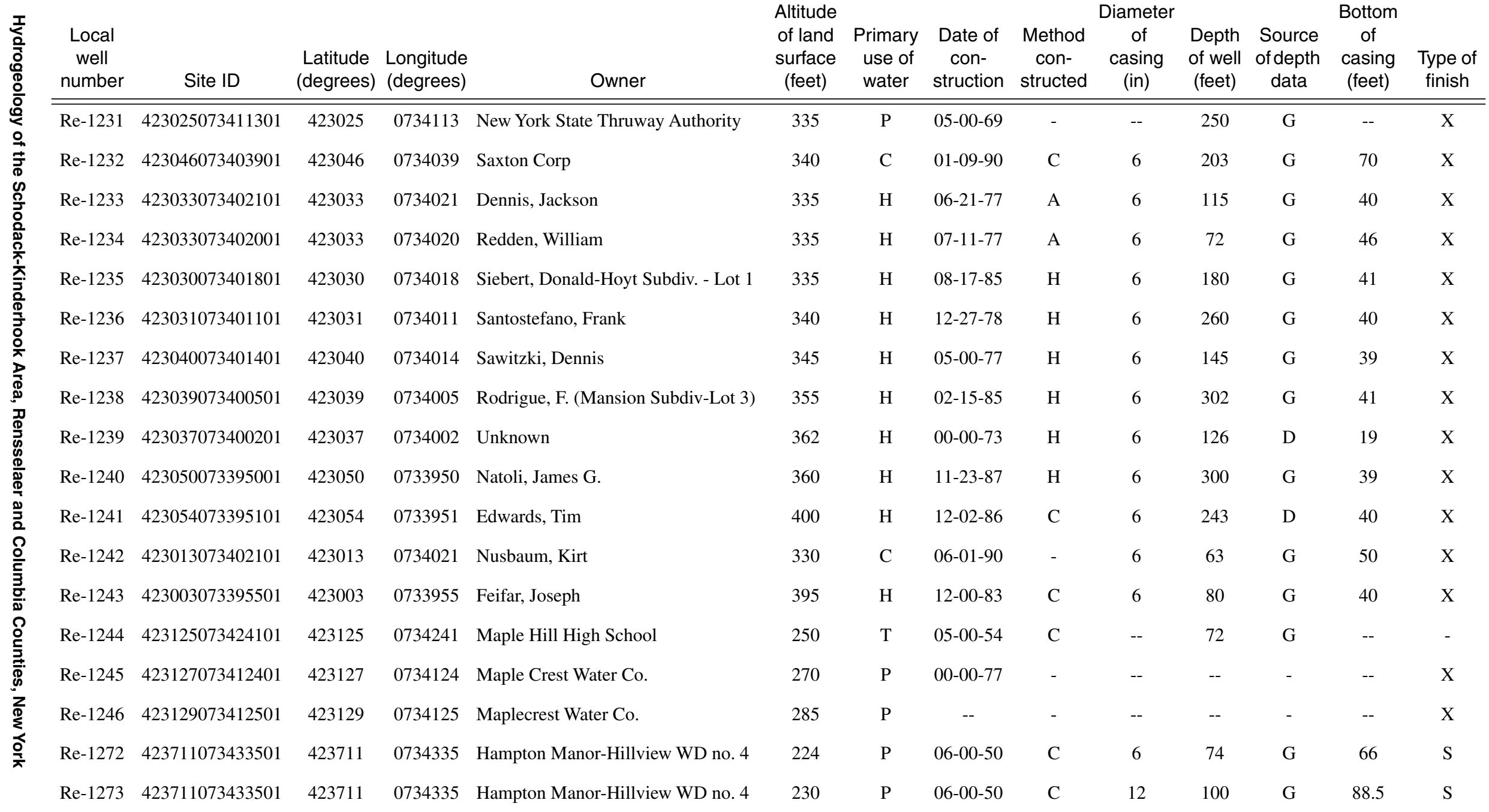


Appendix 1. Records of wells in the Schodack-Kinderhook area, Rensselaer and Columbia Counties, N.Y.

A. Wells north of $42^{\circ} 30^{\prime}$.

\begin{tabular}{|c|c|c|c|c|c|c|c|c|c|}
\hline $\begin{array}{l}\text { Local well } \\
\text { number }\end{array}$ & $\begin{array}{l}\text { Aquifer } \\
\text { code }\end{array}$ & $\begin{array}{l}\text { Lithology } \\
\text { code }\end{array}$ & $\begin{array}{l}\text { Depth } \\
\text { to top } \\
\text { (feet) }\end{array}$ & $\begin{array}{l}\text { Water } \\
\text { level } \\
\text { (feet) }\end{array}$ & $\begin{array}{c}\text { Date water } \\
\text { level } \\
\text { measured }\end{array}$ & $\begin{array}{c}\text { Method } \\
\text { water level } \\
\text { measured }\end{array}$ & $\begin{array}{l}\text { Discharge } \\
\quad(\mathrm{gpm})\end{array}$ & Contractor & Remarks \\
\hline $\operatorname{Re}-1231$ & 377SCCK & SHLE & 42 & 65 & $06-02-69$ & $\mathrm{R}$ & 19 & Hanson & Pumping test data \\
\hline Re-1232 & 377SCCK & SHLE & 70 & 50 & 01-09-90 & - & 6 & Kleinhaus & -- \\
\hline Re-1233 & 377SCCK & SHLE & 15 & 8 & $06-21-77$ & $\mathrm{R}$ & 10 & Hanson & $\mathrm{NO} 3$ as $\mathrm{N},<0.2 \mathrm{mg} / \mathrm{L}, \mathrm{Cl} 2 \mathrm{mg} / \mathrm{L}, 5 / 27 / 86, \mathrm{RCHD}$ \\
\hline $\operatorname{Re}-1234$ & 377SCCK & SHLE & 44 & 7 & $07-11-77$ & $\mathrm{R}$ & 8 & Hanson & $\mathrm{NO} 3$ as $\mathrm{N},<0.2 \mathrm{mg} / \mathrm{L}, \mathrm{Cl} 25 \mathrm{mg} / \mathrm{L}, 9 / 4 / 86, \mathrm{RCHD}$ \\
\hline Re-1235 & 377SCCK & SHLE & 20 & 18 & $08-17-85$ & $\mathrm{R}$ & 20 & Gordon Goold & $\mathrm{NO} 3$ as $\mathrm{N},<0.2 \mathrm{mg} / \mathrm{L}, \mathrm{Cl} 6 \mathrm{mg} / \mathrm{L}, 11 / 14 / 86, \mathrm{RCHD}$ \\
\hline Re-1236 & 377SCCK & SHLE & 16 & 18 & $12-27-78$ & $\mathrm{R}$ & 3 & Gordon Goold & $\mathrm{NO} 3$ as $\mathrm{N},<0.2 \mathrm{mg} / \mathrm{L}, \mathrm{Cl} 30 \mathrm{mg} / \mathrm{L}, 11 / 16 / 83, \mathrm{RCHD}$ \\
\hline Re-1237 & 377SCCK & SHLE & 33 & -- & -- & - & 30 & Shaver & -- \\
\hline $\operatorname{Re}-1238$ & 377SCCK & SHLE & 10 & 50 & $02-15-85$ & $\mathrm{R}$ & 8 & Hanson & $\mathrm{NO} 3$ as $\mathrm{N},<0.2 \mathrm{mg} / \mathrm{L}, \mathrm{Cl} 2 \mathrm{mg} / \mathrm{L}, 3 / 11 / 86, \mathrm{RCHD}$ \\
\hline Re-1239 & 377SCCK & SHLE & 0 & -- & -- & - & 12 & Shaver & -- \\
\hline Re-1240 & 377SCCK & SHLE & 32 & 20 & $11-23-87$ & $\mathrm{R}$ & 7 & Gordon Goold & -- \\
\hline Re-1241 & 377SCCK & SHLE & 26 & -- & -- & - & 5 & Kleinhaus & -- \\
\hline $\operatorname{Re}-1242$ & 377SCCK & SHLE & 48 & 2.83 & $06-12-90$ & $\mathrm{R}$ & 20 & -- & $\mathrm{NO} 3$ as N, $1.4 \mathrm{mg} / \mathrm{L}, \mathrm{Cl} 8 \mathrm{mg} / \mathrm{L}, 6 / 6 / 90, \mathrm{RCHD}$ \\
\hline Re-1243 & 377SCCK & SHLE & 0 & 30 & $12-00-83$ & $\mathrm{R}$ & 6 & Kleinhaus, A & $\mathrm{NO} 3$ as N, $2.1 \mathrm{mg} / \mathrm{L}, \mathrm{Cl} 11 \mathrm{mg} / \mathrm{L}, 2 / 14 / 84$, RCHD \\
\hline Re-1244 & -- & -- & -- & 22 & $05-10-54$ & - & 19 & Hugh Mclean & NO3 as N, $0.15 \mathrm{mg} / \mathrm{L}$, TDS $137 \mathrm{mg} / \mathrm{L}$, abandoned 11/20/81 \\
\hline Re-1245 & 377SCCK & SHLE & -- & 10.5 & $00-00-77$ & $\mathrm{R}$ & 22 & -- & Two abandoned wells nearby \\
\hline Re-1246 & 377SCCK & SHLE & -- & 6.58 & 03-19-87 & $\mathrm{R}$ & 13 & -- & Two abandoned wells nearby \\
\hline Re-1272 & $112 \mathrm{ICNC}$ & SDGL & 47.5 & 19 & $06-00-50$ & $\mathrm{R}$ & 240 & -- & Well rated at 200 gpm; WSA no. 2270 \\
\hline Re-1273 & $112 \mathrm{ICNC}$ & SDGL & 66 & 30 & $10-01-56$ & $\mathrm{R}$ & 600 & Stewart Bros & Well rated at 450 gpm; WSA no. 3074 \\
\hline
\end{tabular}


I. Appendix 1. Records of wells in the Schodack-Kinderhook area, Rensselaer and Columbia Counties, N.Y.

B. Wells south of $42^{\circ} 30^{\prime}$.

\begin{tabular}{|c|c|c|c|c|c|c|c|c|c|c|c|c|c|c|}
\hline $\begin{array}{l}\text { Local } \\
\text { well } \\
\text { number }\end{array}$ & Site ID & $\begin{array}{l}\text { Latitude } \\
\text { (degrees) }\end{array}$ & $\begin{array}{l}\text { Longitude } \\
\text { (degrees) }\end{array}$ & Owner & $\begin{array}{c}\text { Altitude } \\
\text { of land } \\
\text { surface } \\
\text { (feet) }\end{array}$ & $\begin{array}{c}\text { Primary } \\
\text { use of } \\
\text { water }\end{array}$ & $\begin{array}{l}\text { Local } \\
\text { well } \\
\text { number }\end{array}$ & $\begin{array}{c}\text { Date of } \\
\text { con- } \\
\text { struction }\end{array}$ & $\begin{array}{l}\text { Method } \\
\text { con- } \\
\text { structed }\end{array}$ & $\begin{array}{l}\text { Diameter } \\
\text { of casing } \\
\text { (in) }\end{array}$ & $\begin{array}{l}\text { Depth of } \\
\text { well } \\
\text { (feet) }\end{array}$ & $\begin{array}{c}\text { Source } \\
\text { of } \\
\text { depth } \\
\text { data }\end{array}$ & $\begin{array}{l}\text { Bottom } \\
\text { of } \\
\text { casing } \\
\text { (feet) }\end{array}$ & $\begin{array}{l}\text { Type of } \\
\text { finish }\end{array}$ \\
\hline $\operatorname{Re}-624$ & 422849073461301 & 422849 & 0734606 & Schodack Landing School & 75 & $\mathrm{~T}$ & 624 & $00-00-17$ & $\mathrm{C}$ & 6 & 159 & $\mathrm{D}$ & 47.6 & $\mathrm{X}$ \\
\hline Re-635 & 422952073402801 & 422952 & 0734028 & Kingman, V.N. & 325 & $\mathrm{H}$ & 635 & 00-00-38 & $\mathrm{C}$ & 6 & 114 & $\mathrm{D}$ & 14 & $\mathrm{X}$ \\
\hline Re-636 & 422952073402601 & 422952 & 0734022 & Gauseman, Joseph & 340 & $\mathrm{H}$ & 636 & -- & $\mathrm{C}$ & 6 & 50 & $\mathrm{O}$ & 50 & $\mathrm{O}$ \\
\hline Re-637 & 422944073393301 & 422945 & 0733928 & Maier, Hans & 430 & $S$ & 637 & -- & $\mathrm{C}$ & 6 & 97 & $\mathrm{O}$ & 14 & $\mathrm{x}$ \\
\hline Re-638 & 422937073404401 & 422937 & 0734039 & Mark, A. & 330 & $\mathrm{H}$ & 638 & -- & $\mathrm{C}$ & 6 & 135 & $\mathrm{O}$ & 64 & $\mathrm{x}$ \\
\hline Re-639 & 422918073404701 & 422917 & 0734044 & Wendt, John C. & 330 & $\mathrm{C}$ & 639 & 00-00-38 & $\mathrm{C}$ & 6 & 125 & $\mathrm{D}$ & 65 & $\mathrm{x}$ \\
\hline Re-640 & 422923073404701 & 422923 & 0734047 & Wendt, Howard & 325 & $\mathrm{H}$ & 640 & 00-00-31 & $\mathrm{C}$ & 6 & 150 & $\mathrm{D}$ & 50 & $\mathrm{X}$ \\
\hline Re-650 & 422844073422701 & 422844 & 0734221 & Parks, Alonzo & 235 & $\mathrm{H}$ & 650 & $00-00-45$ & $\mathrm{C}$ & 6 & 92 & $\mathrm{D}$ & 92 & $\mathrm{O}$ \\
\hline Re-661 & 422842073455801 & 422842 & 0734550 & Grooten, Albert Jr. & 210 & $\mathrm{H}$ & 661 & 00-00-18 & $\mathrm{C}$ & 6 & 144 & D & 5 & $\mathrm{x}$ \\
\hline Re-662 & 422846073435401 & 422846 & 0734354 & Lantz, Willard & 240 & $\mathrm{H}$ & 662 & -- & $\mathrm{C}$ & 6 & 51 & $\mathrm{O}$ & 20 & $\mathrm{X}$ \\
\hline $\operatorname{Re}-663$ & 422839073440101 & 422840 & 0734354 & Peckham, Earl & 245 & $\mathrm{H}$ & 663 & -- & $\mathrm{C}$ & 6 & 99 & $\mathrm{O}$ & 32 & $\mathrm{X}$ \\
\hline Re-676 & 422853073440601 & 422853 & 0734406 & Steele, Ray & 250 & $\mathrm{H}$ & 676 & 09-07-29 & $\mathrm{C}$ & -- & 100 & $\mathrm{D}$ & -- & $\mathrm{X}$ \\
\hline Re-677 & 422835073435601 & 422835 & 0734356 & Reformed Church of Muitzeskill & 250 & $\mathrm{H}$ & 677 & -- & $\mathrm{C}$ & -- & 180 & $\mathrm{O}$ & -- & $\mathrm{X}$ \\
\hline Re-1114 & 422826073411301 & 422825 & 0734114 & R. Martino & 265.43 & $\mathrm{U}$ & 1114 & -- & - & 6 & 68.7 & $S$ & -- & - \\
\hline Re-1115 & 422838073405801 & 422837 & 0734058 & R. Martino & 298.64 & $\mathrm{U}$ & 1115 & -- & - & 6 & 43 & $S$ & -- & - \\
\hline Re-1116 & 422901073405101 & 422901 & 0734051 & Puccio, George and Paul & 285 & $\mathrm{U}$ & 1116 & -- & - & 6 & 35.5 & S & 35.5 & $\mathrm{O}$ \\
\hline Re-1247 & 422951073405901 & 422951 & 0734059 & Collum, Kenneth Jr. & 315 & $\mathrm{H}$ & 1247 & 09-30-77 & - & 6 & 125 & G & 56 & $\mathrm{X}$ \\
\hline Re-1248 & 422949073405201 & 422949 & 0734052 & Bramah, Jim & 322 & $\mathrm{H}$ & 1248 & $10-29-85$ & - & 6 & 88.5 & G & 88.5 & $\mathrm{O}$ \\
\hline Re-1249 & 422948073405001 & 422948 & 0734050 & Parslow, George & 325 & $\mathrm{H}$ & 1249 & $09-13-83$ & - & 6 & 145 & G & 94 & $\mathrm{X}$ \\
\hline Re-1250 & 422945073404701 & 422945 & 0734047 & Filkins, Tom & 325 & $\mathrm{H}$ & 1250 & $00-00-86$ & - & 6 & 527 & G & 101 & $\mathrm{x}$ \\
\hline Re-1251 & 422947073403801 & 422947 & 0734038 & Lasher, Ronald & 322 & $\mathrm{H}$ & 1251 & -- & - & 6 & 180 & G & 91 & $\mathrm{x}$ \\
\hline Re-1252 & 422944073404101 & 422944 & 0734041 & Walko, Alex & 325 & $\mathrm{H}$ & 1252 & -- & - & 6 & 60 & G & 60 & $\mathrm{O}$ \\
\hline Re-1253 & 422948073402501 & 422948 & 0734025 & Hanaford Bros. Warehouse & 330 & $\mathrm{C}$ & 1253 & $03-03-88$ & $\mathrm{H}$ & 6 & 400 & G & 35 & $\mathrm{x}$ \\
\hline
\end{tabular}


Appendix 1. Records of wells in the Schodack-Kinderhook area, Rensselaer and Columbia Counties, N.Y. B. Wells south of $42^{\circ} 30^{\prime}$.

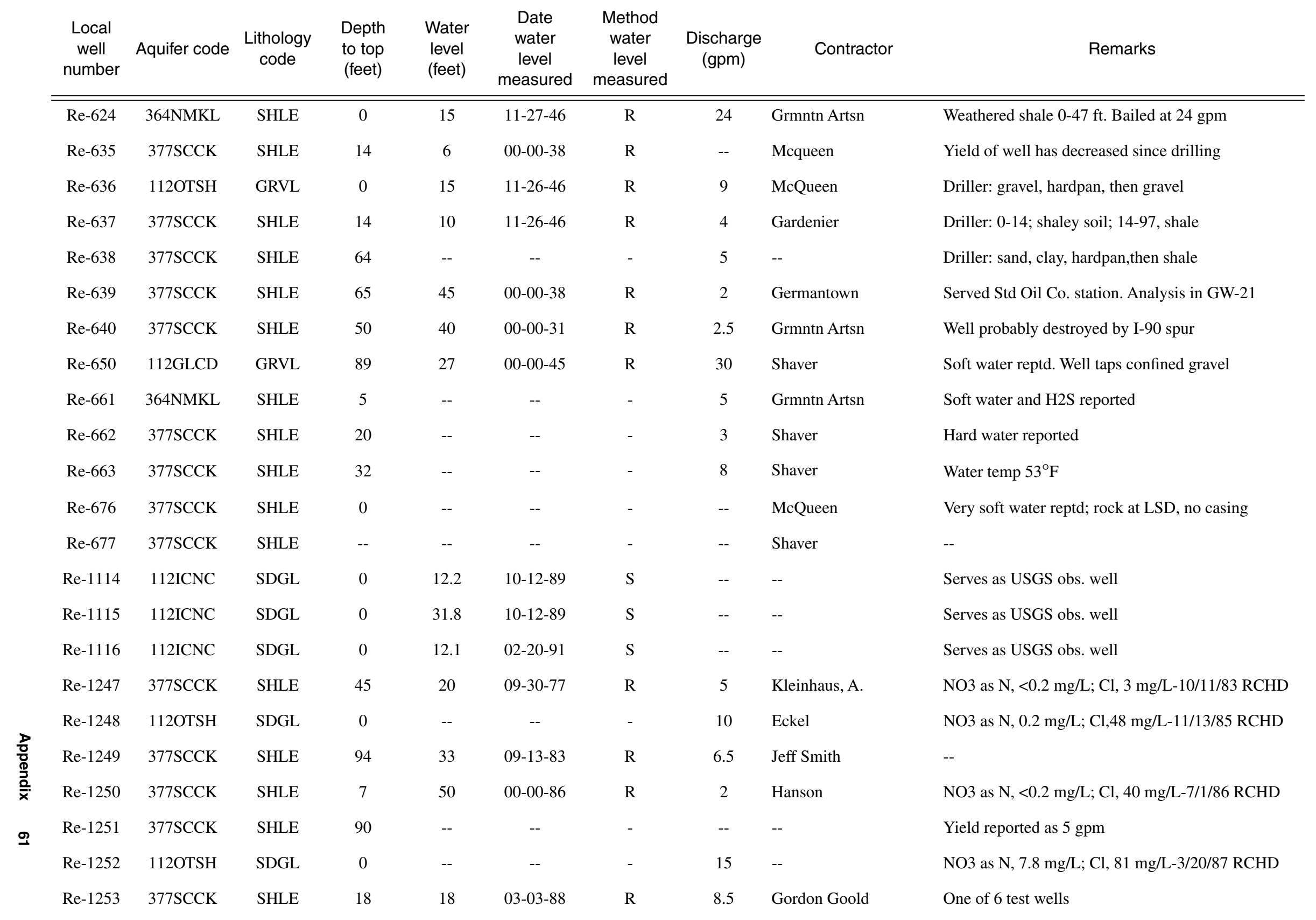


I Appendix 1. Records of wells in the Schodack-Kinderhook area, Rensselaer and Columbia Counties, N.Y.

B. Wells south of $42^{\circ} 30^{\prime}$.

\begin{tabular}{|c|c|c|c|c|c|c|c|c|c|c|c|c|c|c|}
\hline $\begin{array}{l}\text { Local } \\
\text { well } \\
\text { number }\end{array}$ & Site ID & $\begin{array}{l}\text { Latitude } \\
\text { (degrees) }\end{array}$ & $\begin{array}{l}\text { Longitude } \\
\text { (degrees) }\end{array}$ & Owner & $\begin{array}{c}\text { Altitude } \\
\text { of land } \\
\text { surface } \\
\text { (feet) }\end{array}$ & $\begin{array}{c}\text { Primary } \\
\text { use of } \\
\text { water }\end{array}$ & $\begin{array}{c}\text { Local } \\
\text { well } \\
\text { number }\end{array}$ & $\begin{array}{c}\text { Date of } \\
\text { con- } \\
\text { struction }\end{array}$ & $\begin{array}{c}\text { Method } \\
\text { con- } \\
\text { structed }\end{array}$ & $\begin{array}{l}\text { Diameter } \\
\text { of casing } \\
\text { (in) }\end{array}$ & $\begin{array}{l}\text { Depth of } \\
\text { well } \\
\text { (feet) }\end{array}$ & $\begin{array}{c}\text { Source } \\
\text { of } \\
\text { depth } \\
\text { data }\end{array}$ & $\begin{array}{l}\text { Bottom } \\
\text { of } \\
\text { casing } \\
\text { (feet) }\end{array}$ & $\begin{array}{c}\text { Type of } \\
\text { finish }\end{array}$ \\
\hline Re-1254 & 422949073402101 & 422949 & 0734021 & Hannaford Bros. Warehouse & 335 & $\mathrm{C}$ & 1254 & 03-04-88 & $\mathrm{H}$ & 6 & 400 & G & 35 & $\mathrm{X}$ \\
\hline Re-1255 & 422947073401701 & 422947 & 0734017 & Hannaford Bros. Warehouse & 338 & $\mathrm{C}$ & 1255 & $03-10-88$ & $\mathrm{H}$ & 6 & 400 & G & 35 & $\mathrm{X}$ \\
\hline Re-1256 & 422942073402401 & 422942 & 0734024 & Hannaford Bros. Warehouse & 350 & $\mathrm{C}$ & 1256 & $11-01-89$ & $\mathrm{H}$ & 6 & 435 & G & 52 & $\mathrm{X}$ \\
\hline Re-1257 & 422945073402201 & 422945 & 0734022 & Hannaford Bros. Warehouse & 340 & $\mathrm{C}$ & 1257 & $10-28-89$ & $\mathrm{H}$ & 6 & 435 & G & 50 & $\mathrm{x}$ \\
\hline Re-1258 & 422946073402201 & 422946 & 0734022 & Hannaford Bros. Warehouse & 335 & $\mathrm{C}$ & 1258 & $10-26-89$ & $\mathrm{H}$ & 6 & 435 & G & 40 & $\mathrm{X}$ \\
\hline Re-1259 & 422953073394601 & 422953 & 0733946 & Simpson, Earl & 410 & $\mathrm{H}$ & 1259 & $08-00-88$ & $\mathrm{H}$ & 6 & 200 & G & 40 & $\mathrm{X}$ \\
\hline Re-1260 & 422943073413001 & 422943 & 0734130 & Clarke, K. \& J. & 260 & $\mathrm{H}$ & 1260 & $10-26-79$ & $\mathrm{H}$ & 6 & 385 & G & 40 & $\mathrm{X}$ \\
\hline Re-1261 & 422937073413801 & 422937 & 0734138 & Spring, Earl & 280 & $\mathrm{H}$ & 1261 & $04-00-86$ & - & 6 & 120 & G & 40 & $\mathrm{X}$ \\
\hline Re-1262 & 422936073413601 & 422936 & 0734136 & Weaver, Veratis & 265 & $\mathrm{H}$ & 1262 & $03-00-88$ & $\mathrm{H}$ & 6 & 250 & G & 40 & $\mathrm{X}$ \\
\hline Re-1263 & 422933073415801 & 422933 & 0734158 & Schoonover, Linda & 250 & $\mathrm{H}$ & 1263 & $08-15-85$ & $\mathrm{C}$ & 6 & 210 & G & 89 & $\mathrm{X}$ \\
\hline Re-1264 & 422922073414801 & 422922 & 0734148 & Hutchinson, Frederick & 290 & $\mathrm{H}$ & 1264 & $06-06-78$ & - & 6 & 350 & G & 80 & $\mathrm{X}$ \\
\hline Re-1265 & 422921073414601 & 422921 & 0734146 & Delong, Don & 310 & $\mathrm{H}$ & 1265 & $04-26-85$ & - & 6 & 260 & G & 68 & $\mathrm{X}$ \\
\hline Re-1266 & 422957073422501 & 422957 & 0734225 & Swartz, Edgar & 230 & $\mathrm{H}$ & 1266 & -- & $\mathrm{C}$ & 6 & 90 & G & 90 & $\mathrm{O}$ \\
\hline Re-1267 & 422900073430801 & 422900 & 0734308 & Sultan, R.A. (Lot 6) & 222 & $\mathrm{H}$ & 1267 & $07-00-87$ & - & 6 & 85 & G & 85 & $\mathrm{O}$ \\
\hline Re-1268 & 422827073423001 & 422827 & 0734230 & Ziegler, Edwin & 260 & $\mathrm{H}$ & 1268 & $12-13-87$ & $\mathrm{H}$ & 6 & 325 & G & 95 & $\mathrm{X}$ \\
\hline Re-1269 & 422833073423601 & 422833 & 0734236 & Walther, Carol & 230 & $\mathrm{H}$ & 1269 & $11-00-83$ & - & 6 & 165 & G & 70 & $\mathrm{X}$ \\
\hline Re-1270 & 422830073423201 & 422830 & 0734232 & Osborne, Robert & 250 & $\mathrm{H}$ & 1270 & 08-00-87 & - & 6 & 280 & G & 100 & $\mathrm{X}$ \\
\hline Re-1271 & 422825073411801 & 422825 & 0734118 & Campbell, Robert & 265 & $\mathrm{H}$ & 1271 & -- & - & 6 & 240 & - & 117 & $\mathrm{X}$ \\
\hline $\mathrm{Cb}-1$ & 422724073461901 & 422724 & 0734619 & Van Allen, Warren & 60 & $\mathrm{H}$ & 1 & $00-00-31$ & $\mathrm{C}$ & 6 & 87 & D & 45 & $\mathrm{X}$ \\
\hline $\mathrm{Cb}-2$ & 422743073450201 & 422746 & 0734504 & Schrodt Bros. & 280 & $\mathrm{H}$ & 2 & $00-00-42$ & $\mathrm{C}$ & 6 & 203 & D & 67 & $\mathrm{X}$ \\
\hline $\mathrm{Cb}-3$ & 422809073434701 & 422809 & 0734347 & Vrooman, Mr. & 260 & $\mathrm{H}$ & 3 & $00-00-47$ & $\mathrm{C}$ & 6 & 98 & $\mathrm{D}$ & 60 & $\mathrm{X}$ \\
\hline $\mathrm{Cb}-4$ & 422714073444901 & 422714 & 0734449 & Pucket & 280 & $\mathrm{H}$ & 4 & $00-00-39$ & $\mathrm{C}$ & 6 & 95 & $\mathrm{D}$ & 45 & $\mathrm{X}$ \\
\hline $\mathrm{Cb}-5$ & 422709073441001 & 422707 & 0734408 & Gibson \& Son & 230 & $\mathrm{H}$ & 5 & -- & $\mathrm{C}$ & 6 & 90 & $\mathrm{D}$ & 20 & $\mathrm{X}$ \\
\hline
\end{tabular}


Appendix 1. Records of wells in the Schodack-Kinderhook area, Rensselaer and Columbia Counties, N.Y. B. Wells south of $42^{\circ} 30^{\prime}$.

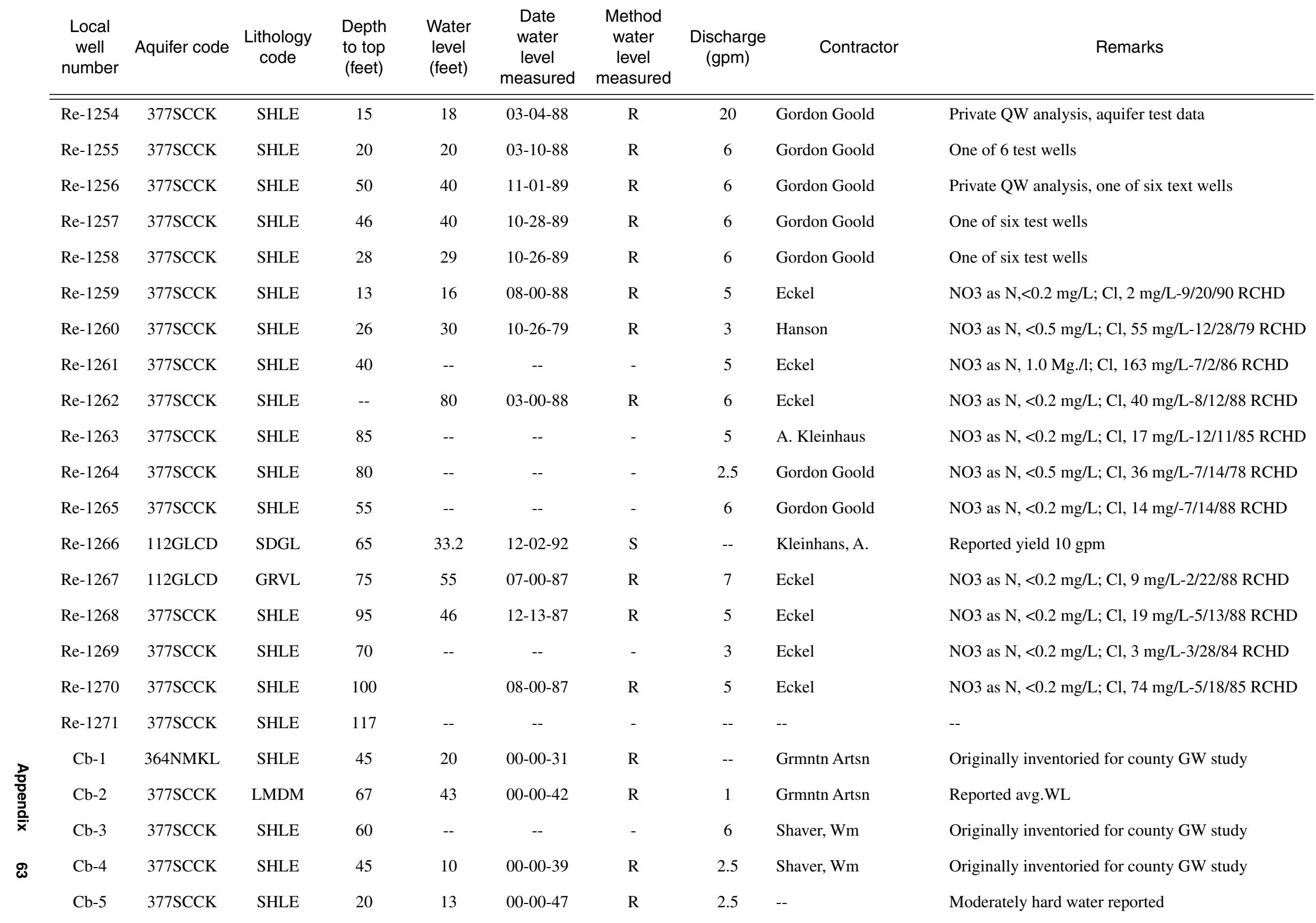


Appendix 1. Records of wells in the Schodack-Kinderhook area, Rensselaer and Columbia Counties, N.Y.

B. Wells south of $42^{\circ} 30^{\prime}$.

\begin{tabular}{|c|c|c|c|c|c|c|c|c|c|c|c|c|c|c|}
\hline $\begin{array}{l}\text { Local } \\
\text { well } \\
\text { number }\end{array}$ & Site ID & $\begin{array}{l}\text { Latitude } \\
\text { (degrees) }\end{array}$ & $\begin{array}{l}\text { Longitude } \\
\text { (degrees) }\end{array}$ & Owner & $\begin{array}{c}\text { Altitude } \\
\text { of land } \\
\text { surface } \\
\text { (feet) }\end{array}$ & $\begin{array}{c}\text { Primary } \\
\text { use of } \\
\text { water }\end{array}$ & $\begin{array}{l}\text { Local } \\
\text { well } \\
\text { number }\end{array}$ & $\begin{array}{l}\text { Date of } \\
\text { con- } \\
\text { struction }\end{array}$ & $\begin{array}{l}\text { Method } \\
\text { con- } \\
\text { structed }\end{array}$ & $\begin{array}{l}\text { Diameter } \\
\text { of casing } \\
\text { (in) }\end{array}$ & $\begin{array}{l}\text { Depth of } \\
\text { well } \\
\text { (feet) }\end{array}$ & $\begin{array}{c}\text { Source } \\
\text { of } \\
\text { depth } \\
\text { data }\end{array}$ & $\begin{array}{l}\text { Bottom } \\
\text { of } \\
\text { casing } \\
\text { (feet) }\end{array}$ & $\begin{array}{c}\text { Type of } \\
\text { finish }\end{array}$ \\
\hline $\mathrm{Cb}-6$ & 422657073440001 & 422657 & 0734400 & Lee, Mr. & 220 & $\mathrm{H}$ & 6 & $00-00-34$ & $\mathrm{C}$ & 6 & 39 & $\mathrm{D}$ & 10 & $\mathrm{X}$ \\
\hline $\mathrm{Cb}-7$ & 422750073420001 & 422750 & 0734200 & Winchell, Ray & 280 & $\mathrm{H}$ & 7 & $00-00-42$ & $\mathrm{C}$ & 6 & 162 & D & 96 & $\mathrm{X}$ \\
\hline $\mathrm{Cb}-8$ & 422732073414301 & 422732 & 0734143 & Stahlman, Frank \& Willard & 300 & $\mathrm{H}$ & 8 & 00-00-08 & $\mathrm{C}$ & 6 & 90 & $\mathrm{O}$ & 90 & $\mathrm{O}$ \\
\hline $\mathrm{Cb}-9$ & 422716073414301 & 422716 & 0734143 & St Joseph of Holy Cross & 300 & $\mathrm{H}$ & 9 & -- & $\mathrm{D}$ & 54 & 20 & $\mathrm{O}$ & 20 & $\mathrm{~W}$ \\
\hline $\mathrm{Cb}-10$ & 422705073413901 & 422705 & 0734139 & Campbell, P. & 308 & $\mathrm{H}$ & 10 & 06-00-39 & $\mathrm{C}$ & 6 & 119 & $\mathrm{D}$ & 119 & $\mathrm{O}$ \\
\hline $\mathrm{Cb}-11$ & 422731073410801 & 422731 & 0734108 & Camp Orinsekwa & 310 & $\mathrm{H}$ & 11 & 00-00-38 & $\mathrm{C}$ & 6 & 31 & $\mathrm{D}$ & 31 & $\mathrm{O}$ \\
\hline $\mathrm{Cb}-12$ & 422714073410701 & 422713 & 0734112 & Stahlman, Ralph \& Harry & 321 & $\mathrm{H}$ & 12 & $00-00-36$ & $\mathrm{C}$ & 6 & 90 & $\mathrm{D}$ & 90 & $\mathrm{O}$ \\
\hline $\mathrm{Cb}-13$ & 422722073400001 & 422722 & 0734000 & Dudley, Ralph (Kinderhook Orchards) & 330 & $\mathrm{H}$ & 13 & $07-00-44$ & $\mathrm{C}$ & 6 & 195 & $\mathrm{D}$ & 21 & $\mathrm{X}$ \\
\hline $\mathrm{Cb}-14$ & 422723073394301 & 422723 & 0733943 & Dudley, Ralph (Kinderhook Orchards) & 325 & $\mathrm{H}$ & 14 & $06-00-44$ & $\mathrm{C}$ & 6 & 96 & $\mathrm{D}$ & 5 & $\mathrm{X}$ \\
\hline $\mathrm{Cb}-15$ & 422737073394201 & 422737 & 0733942 & Kinderhook Orchards, Inc. & 410 & $\mathrm{H}$ & 15 & $05-00-42$ & $\mathrm{C}$ & 6 & 352 & $\mathrm{D}$ & 165 & $\mathrm{X}$ \\
\hline $\mathrm{Cb}-16$ & 422743073392701 & 422743 & 0733927 & Kinderhook Orchards, Inc. & 299 & I & 16 & $00-00-25$ & $\mathrm{~V}$ & 1.25 & 20 & $\mathrm{O}$ & 17 & $\mathrm{~T}$ \\
\hline $\mathrm{Cb}-17$ & 422743073392702 & 422743 & 0733927 & Kinderhook Orchards, Inc. & 299 & I & 17 & $00-00-25$ & $\mathrm{~V}$ & 1.25 & 20 & $\mathrm{O}$ & 17 & $\mathrm{~T}$ \\
\hline $\mathrm{Cb}-18$ & 422743073392703 & 422743 & 0733927 & Kinderhook Orchards, Inc. & 299 & I & 18 & $00-00-25$ & $\mathrm{~V}$ & 1.25 & 20 & $\mathrm{O}$ & 17 & $\mathrm{~T}$ \\
\hline $\mathrm{Cb}-19$ & 422743073392704 & 422743 & 0733927 & Kinderhook Orchards, Inc. & 299 & I & 19 & $00-00-25$ & $\mathrm{~V}$ & 1.25 & 20 & $\mathrm{O}$ & 17 & $\mathrm{~T}$ \\
\hline $\mathrm{Cb}-20$ & 422825073380801 & 422825 & 0733808 & Sheffield Farms, Inc. & 350 & $\mathrm{C}$ & 20 & -- & $\mathrm{V}$ & 2 & 20 & $\mathrm{O}$ & 20 & $\mathrm{~T}$ \\
\hline $\mathrm{Cb}-21$ & 422817073375401 & 422817 & 0733754 & North Chatham Fire Co. Test Well & 350 & $\mathrm{~F}$ & 21 & $05-00-42$ & $\mathrm{C}$ & 6 & 32 & $\mathrm{D}$ & 32 & $\mathrm{O}$ \\
\hline $\mathrm{Cb}-53$ & 422637073373401 & 422636 & 0733731 & Hacker, Dr. Christian & 440 & $\mathrm{H}$ & 53 & -- & $\mathrm{C}$ & 6 & 85 & $\mathrm{D}$ & 19 & $\mathrm{X}$ \\
\hline $\mathrm{Cb}-54$ & 422647073385301 & 422647 & 0733853 & Nolan, Mrs. & 310 & $\mathrm{H}$ & 54 & $08-00-45$ & $\mathrm{C}$ & 6 & 122 & $\mathrm{D}$ & 9 & $\mathrm{X}$ \\
\hline $\mathrm{Cb}-55$ & 422653073385401 & 422652 & 0733852 & Hover, Mike & 320 & $\mathrm{H}$ & 55 & 00-00-30 & $\mathrm{C}$ & 6 & 85 & $\mathrm{D}$ & 25.5 & $\mathrm{x}$ \\
\hline $\mathrm{Cb}-56$ & 422657073385101 & 422657 & 0733851 & Carmadine, Mrs. Charles & 330 & $\mathrm{H}$ & 56 & $00-00-22$ & $\mathrm{C}$ & 6 & 41 & $\mathrm{D}$ & 41 & $\mathrm{O}$ \\
\hline Cb-57 & 422701073385001 & 422701 & 0733850 & Johnson, C. & 330 & $\mathrm{H}$ & 57 & $12-00-44$ & $\mathrm{C}$ & 6 & 72 & $\mathrm{D}$ & 24 & $\mathrm{X}$ \\
\hline Cb-58 & 422629073394101 & 422629 & 0733941 & Van Hoesen, Henry & 320 & $\mathrm{U}$ & 58 & -- & $\mathrm{C}$ & 6 & 186 & $\mathrm{D}$ & 130 & $\mathrm{X}$ \\
\hline Cb-59 & 422604073392801 & 422600 & 0733929 & Standard Oil Co & 320 & $\mathrm{U}$ & 59 & $00-00-27$ & c & 6 & 40 & $\mathrm{O}$ & 37 & $\mathrm{~T}$ \\
\hline
\end{tabular}


Appendix 1. Records of wells in the Schodack-Kinderhook area, Rensselaer and Columbia Counties, N.Y. B. Wells south of $42^{\circ} 30^{\prime}$.

\begin{tabular}{|c|c|c|c|c|c|c|c|c|c|}
\hline $\begin{array}{c}\text { Local } \\
\text { well } \\
\text { number }\end{array}$ & Aquifer code & $\begin{array}{l}\text { Lithology } \\
\text { code }\end{array}$ & $\begin{array}{l}\text { Depth } \\
\text { to top } \\
\text { (feet) }\end{array}$ & $\begin{array}{c}\text { Water } \\
\text { level } \\
\text { (feet) }\end{array}$ & $\begin{array}{c}\text { Date } \\
\text { water } \\
\text { level } \\
\text { measured }\end{array}$ & $\begin{array}{l}\text { Method } \\
\text { water } \\
\text { level } \\
\text { measured }\end{array}$ & $\begin{array}{l}\text { Discharge } \\
\quad(\mathrm{gpm})\end{array}$ & Contractor & Remarks \\
\hline $\mathrm{Cb}-6$ & 377SCCK & SHLE & 6 & 8 & $00-00-34$ & $\mathrm{R}$ & 4 & Shaver & Originally inventoried for county GW study \\
\hline $\mathrm{Cb}-7$ & 377SCCK & SHLE & 87 & 50 & $00-00-42$ & $\mathrm{R}$ & .75 & Grmntn Artsn & Originally inventoried for county GW study \\
\hline $\mathrm{Cb}-8$ & $112 \mathrm{ICNC}$ & GRVL & 89 & 40 & $00-00-38$ & $\mathrm{R}$ & 3 & Mcqueen, J C & Originally inventoried for county GW study \\
\hline $\mathrm{Cb}-9$ & 112OTSH & SAND & 0 & 16.9 & $10-11-45$ & $S$ & 40 & -- & Rock at $100 \mathrm{ft}$ from nearby drilled well \\
\hline $\mathrm{Cb}-10$ & 112GLCD & GRVL & 118 & 46 & 06-00-39 & $\mathrm{R}$ & 15 & Goold Bros & Originally inventoried for county GW study \\
\hline $\mathrm{Cb}-11$ & $112 \mathrm{ICNC}$ & SAND & 14 & -- & -- & - & 25 & Shaver, Wm & Originally inventoried for county GW study \\
\hline $\mathrm{Cb}-12$ & 112GLCD & GRVL & 89 & 18 & $00-00-36$ & $\mathrm{R}$ & 6 & Shaver, Wm & Hard water reported, rock at $90 \mathrm{ft}$ \\
\hline $\mathrm{Cb}-13$ & 377SCCK & SLTE & 21 & 17 & $07-00-44$ & $\mathrm{R}$ & 9 & Goold Bros & QW analysis by NYSDOH in GW-25 \\
\hline $\mathrm{Cb}-14$ & 377SCCK & SLTE & 5 & 16 & $06-00-44$ & $\mathrm{R}$ & -- & Goold Bros & Originally inventoried for county GW study \\
\hline $\mathrm{Cb}-15$ & 377SCCK & SHLE & 165 & 104 & $05-00-42$ & $\mathrm{R}$ & 3.5 & Goold Bros & Originally inventoried for county GW study \\
\hline $\mathrm{Cb}-16$ & $112 \mathrm{ICNC}$ & GRVL & 0 & 11 & $00-00-45$ & $\mathrm{R}$ & 15 & Former Owner & 4 driven wells in pit-common suction \\
\hline Cb-17 & $112 \mathrm{ICNC}$ & GRVL & 0 & 11 & $00-00-45$ & $\mathrm{R}$ & 15 & Former Owner & 4 driven wells in pit-common suction \\
\hline $\mathrm{Cb}-18$ & $112 \mathrm{ICNC}$ & GRVL & 0 & 11 & $00-00-45$ & $\mathrm{R}$ & 15 & Former Owner & 4 driven wells in pit-common suction \\
\hline Cb-19 & $112 \mathrm{ICNC}$ & GRVL & 0 & 11 & $00-00-45$ & $\mathrm{R}$ & 15 & Former Owner & 4 driven wells in pit-common suction \\
\hline $\mathrm{Cb}-20$ & 112OTSH & SAND & 15 & 16 & $01-08-47$ & $\mathrm{R}$ & -- & -- & Milk transfer sta. QW analysis in GW-25. \\
\hline $\mathrm{Cb}-21$ & 112OTSH & SDGL & 0 & 7 & $05-00-42$ & $\mathrm{R}$ & 68 & Goold Bros & Originally inventoried for county GW study \\
\hline $\mathrm{Cb}-53$ & 371TCSQ & SLTE & 19 & 9 & $10-16-45$ & $\mathrm{R}$ & 16 & Goold Bros & Stuyvesant Falls Fm. \\
\hline $\mathrm{Cb}-54$ & 371TCSQ & SLTE & 9 & 12 & $08-00-45$ & $\mathrm{R}$ & -- & Goold Bros & Originally inventoried for county GW study \\
\hline $\mathrm{Cb}-55$ & 371TCSQ & SHLE & 25 & 18 & $00-00-30$ & $\mathrm{R}$ & 3 & Wm Shaver & Original $33 \mathrm{ft}$ well deepened to $85 \mathrm{ft}-1930$ \\
\hline $\mathrm{Cb}-56$ & $112 \mathrm{ICNC}$ & GRVL & 35 & 27.5 & $00-00-22$ & $\mathrm{R}$ & 1.0 & Grmntn Artsn & -- \\
\hline $\mathrm{Cb}-57$ & 371TCSQ & SLTE & 24 & 28 & $12-00-44$ & $\mathrm{R}$ & 42 & Goold Bros. & Originally inventoried for county GW study \\
\hline $\mathrm{Cb}-58$ & $377 N S S U$ & SHLE & 130 & -- & -- & - & -- & Grmntn Artsn & Originally inventoried for county GW study \\
\hline Cb-59 & 112OTSH & SAND & 0 & 15 & $00-00-27$ & $\mathrm{R}$ & 15 & Grmntn Artsn & Used from 1927-30, abandoned since 1930 \\
\hline
\end{tabular}


I Appendix 1. Records of wells in the Schodack-Kinderhook area, Rensselaer and Columbia Counties, N.Y.

B. Wells south of $42^{\circ} 30^{\prime}$.

\begin{tabular}{|c|c|c|c|c|c|c|c|c|c|c|c|c|c|c|}
\hline $\begin{array}{l}\text { Local } \\
\text { well } \\
\text { number }\end{array}$ & Site ID & $\begin{array}{c}\text { Latitude } \\
\text { (degrees) }\end{array}$ & $\begin{array}{l}\text { Longitude } \\
\text { (degrees) }\end{array}$ & Owner & $\begin{array}{c}\text { Altitude } \\
\text { of land } \\
\text { surface } \\
\text { (feet) }\end{array}$ & $\begin{array}{c}\text { Primary } \\
\text { use of } \\
\text { water }\end{array}$ & $\begin{array}{l}\text { Local } \\
\text { well } \\
\text { number }\end{array}$ & $\begin{array}{l}\text { Date of } \\
\text { con- } \\
\text { struction }\end{array}$ & $\begin{array}{l}\text { Method } \\
\text { con- } \\
\text { structed }\end{array}$ & $\begin{array}{l}\text { Diameter } \\
\text { of casing } \\
\text { (in) }\end{array}$ & $\begin{array}{c}\text { Depth of } \\
\text { well } \\
\text { (feet) }\end{array}$ & $\begin{array}{c}\text { Source } \\
\text { of } \\
\text { depth } \\
\text { data }\end{array}$ & $\begin{array}{l}\text { Bottom } \\
\text { of } \\
\text { casing } \\
\text { (feet) }\end{array}$ & $\begin{array}{c}\text { Type of } \\
\text { finish }\end{array}$ \\
\hline $\mathrm{Cb}-60$ & 422533073395301 & 422533 & 0733953 & Ross, Sylvester & 310 & $\mathrm{U}$ & 60 & 00-00-20 & $\mathrm{C}$ & 6 & 284 & $\mathrm{D}$ & -- & $\mathrm{X}$ \\
\hline $\mathrm{Cb}-61$ & 422503073394801 & 422458 & 0733943 & Mitchell, Mrs. Abraham & 310 & $\mathrm{H}$ & 61 & 00-00-36 & $\mathrm{C}$ & 4 & 45 & $\mathrm{D}$ & 45 & $\mathrm{O}$ \\
\hline $\mathrm{Cb}-62$ & 422605073402201 & 422605 & 0734022 & Wassaic State School & 310 & $\mathrm{~T}$ & 62 & 00-00-16 & $\mathrm{C}$ & 72 & 64 & $\mathrm{D}$ & 64 & $\mathrm{O}$ \\
\hline $\mathrm{Cb}-63$ & 422608073402101 & 422605 & 0734020 & Wassaic State School & 310 & $\mathrm{~T}$ & 63 & 00-00-34 & $\mathrm{D}$ & 60 & 20 & $S$ & 20 & $\mathrm{~W}$ \\
\hline $\mathrm{Cb}-64$ & 422604073403301 & 422604 & 0734033 & Wassaic State School & 312 & $S$ & 64 & 00-00-10 & $\mathrm{D}$ & 36 & 22 & $\mathrm{O}$ & 22 & $\mathrm{~W}$ \\
\hline $\mathrm{Cb}-65$ & 422643073401801 & 422643 & 0734018 & Zippin, J. & 320 & $\mathrm{H}$ & 65 & 00-00-32 & $\mathrm{C}$ & 6 & 96 & $\mathrm{O}$ & 40 & $\mathrm{X}$ \\
\hline $\mathrm{Cb}-66$ & 422650073400701 & 422646 & 0734006 & Winslow, Paul & 315 & $\mathrm{H}$ & 66 & 00-00-19 & $\mathrm{C}$ & 6 & 82 & $\mathrm{D}$ & 25 & $\mathrm{X}$ \\
\hline $\mathrm{Cb}-67$ & 422641073411001 & 422638 & 0734110 & Davidson Bros. & 310 & $\mathrm{C}$ & 67 & $07-00-43$ & $\mathrm{C}$ & 6 & 156 & $\mathrm{D}$ & 106 & $\mathrm{X}$ \\
\hline $\mathrm{Cb}-68$ & 422634073410601 & 422638 & 0734112 & Davidson Bros. & 310 & $\mathrm{H}$ & 68 & 00-00-30 & $\mathrm{C}$ & 6 & 100 & $\mathrm{D}$ & 100 & $\mathrm{O}$ \\
\hline $\mathrm{Cb}-69$ & 422603073412601 & 422559 & 0734127 & Myers, Dudley & 300 & $\mathrm{C}$ & 69 & $00-00-43$ & $\mathrm{C}$ & 6 & 70 & $\mathrm{D}$ & 70 & $\mathrm{O}$ \\
\hline $\mathrm{Cb}-70$ & 422547073411801 & 422547 & 0734118 & Pierce Farm & 305 & $\mathrm{H}$ & 70 & $00-00-24$ & $\mathrm{C}$ & 6 & 86 & $\mathrm{D}$ & 86 & $\mathrm{O}$ \\
\hline $\mathrm{Cb}-71$ & 422539073412001 & 422539 & 0734120 & Phillip, Joseph & 301 & $\mathrm{H}$ & 71 & 00-00-39 & V & 2 & 12 & $\mathrm{O}$ & 9 & $\mathrm{~T}$ \\
\hline $\mathrm{Cb}-72$ & 422538073412501 & 422535 & 0734125 & Pross, E. & 300 & $\mathrm{H}$ & 72 & 00-00-41 & $\mathrm{C}$ & 6 & 136 & $\mathrm{D}$ & 136 & $\mathrm{O}$ \\
\hline $\mathrm{Cb}-73$ & 422459073420801 & 422459 & 0734208 & Judson, Paul & 285 & $\mathrm{H}$ & 73 & 00-00-35 & $\mathrm{C}$ & 48 & 45 & $\mathrm{D}$ & 15 & $\mathrm{X}$ \\
\hline $\mathrm{Cb}-74$ & 422505073422501 & 422502 & 0734225 & Loyds, J.B. & 275 & $\mathrm{H}$ & 74 & $00-00-20$ & $\mathrm{C}$ & 6 & 238 & $\mathrm{D}$ & 89 & $\mathrm{X}$ \\
\hline $\mathrm{Cb}-75$ & 422527073422101 & 422526 & 0734223 & Davenport, J. & 265 & $\mathrm{H}$ & 75 & 00-00-20 & $\mathrm{C}$ & 6 & 138 & $\mathrm{D}$ & 138 & $\mathrm{O}$ \\
\hline $\mathrm{Cb}-76$ & 422608073421901 & 422608 & 0734219 & Dahlgren Bros. & 280 & $\mathrm{H}$ & 76 & $04-00-45$ & $\mathrm{C}$ & 6 & 100 & $\mathrm{D}$ & 91 & $\mathrm{X}$ \\
\hline Cb-77 & 422611073421901 & 422608 & 0734219 & Dahlgren Bros. & 280 & $\mathrm{H}$ & 77 & $00-00-38$ & $\mathrm{D}$ & 60 & 25 & $\mathrm{O}$ & 25 & W \\
\hline $\mathrm{Cb}-78$ & 422329073421101 & 422234 & 0734318 & Hinds, Mrs. Spencer & 220 & $\mathrm{H}$ & 78 & $04-00-43$ & $\mathrm{C}$ & 6 & 161 & $\mathrm{D}$ & 123 & $\mathrm{X}$ \\
\hline $\mathrm{Cb}-79$ & 422519073425601 & 422518 & 0734256 & Loyds, J.B. & 230 & $\mathrm{H}$ & 79 & $00-00-22$ & $\mathrm{C}$ & 6 & 185 & $\mathrm{D}$ & 75 & $\mathrm{X}$ \\
\hline $\mathrm{Cb}-80$ & 422536073435901 & 422535 & 0734355 & Leiser, George & 240 & $\mathrm{H}$ & 80 & 09-00-30 & $\mathrm{C}$ & 6 & 88 & $\mathrm{D}$ & 6 & $\mathrm{X}$ \\
\hline $\mathrm{Cb}-81$ & 422509073443201 & 422509 & 0734432 & Fowler, Harold & 280 & $\mathrm{H}$ & 81 & 00-00-41 & $\mathrm{C}$ & 6 & 156 & $\mathrm{D}$ & 65 & $\mathrm{X}$ \\
\hline $\mathrm{Cb}-82$ & 422505073443801 & 422500 & 0734440 & Estate of Fred Keene & 225 & $\mathrm{H}$ & 82 & 00-00-31 & $\mathrm{C}$ & 6 & 95 & D & 7 & $\mathrm{X}$ \\
\hline
\end{tabular}


Appendix 1. Records of wells in the Schodack-Kinderhook area, Rensselaer and Columbia Counties, N.Y. B. Wells south of $42^{\circ} 30^{\prime}$.

\begin{tabular}{|c|c|c|c|c|c|c|c|c|c|}
\hline $\begin{array}{c}\text { Local } \\
\text { well } \\
\text { number }\end{array}$ & Aquifer code & $\begin{array}{l}\text { Lithology } \\
\text { code }\end{array}$ & $\begin{array}{l}\text { Depth } \\
\text { to top } \\
\text { (feet) }\end{array}$ & $\begin{array}{l}\text { Water } \\
\text { level } \\
\text { (feet) }\end{array}$ & $\begin{array}{c}\text { Date } \\
\text { water } \\
\text { level } \\
\text { measured }\end{array}$ & $\begin{array}{l}\text { Method } \\
\text { water } \\
\text { level } \\
\text { measured }\end{array}$ & $\begin{array}{l}\text { Discharge } \\
\text { (gpm) }\end{array}$ & Contractor & Remarks \\
\hline $\mathrm{Cb}-60$ & 377NSSU & SHLE & -- & 24 & $00-00-20$ & $\mathrm{R}$ & -- & Grmntn Artsn & Depth to bedrock reported at $100+\mathrm{ft}$ \\
\hline $\mathrm{Cb}-61$ & $112 \mathrm{ICNC}$ & GRVL & 20 & 20 & 00-00-36 & $\mathrm{R}$ & 10 & Shaver, Wm & Soft water reported \\
\hline $\mathrm{Cb}-62$ & 112GLCD & SAND & 6 & 19 & $10-11-45$ & $\mathrm{R}$ & 2 & Grmntn Artsn & Dug well installed around existing 6 in well \\
\hline $\mathrm{Cb}-63$ & 112OTSH & SAND & 0 & 16 & $10-11-45$ & $S$ & 15 & Owner & QW analysis in table 4, Bulletin GW-25 \\
\hline $\mathrm{Cb}-64$ & 112OTSH & SAND & -- & 18 & $10-11-45$ & $\mathrm{R}$ & -- & -- & Originally inventoried for county GW study \\
\hline $\mathrm{Cb}-65$ & 377SCCK & SLTE & 40 & 16 & $00-00-32$ & $\mathrm{R}$ & 9 & Hall \& Co & Well drilled in existing $30 \mathrm{ft}$ dug well \\
\hline $\mathrm{Cb}-66$ & 377SCCK & SHLE & 10 & 29 & 00-00-19 & $\mathrm{R}$ & 6 & Grmntn Artsn & Reported avg WL \\
\hline $\mathrm{Cb}-67$ & 377SCCK & SLTE & 106 & 14 & $07-00-43$ & $\mathrm{R}$ & 11 & Goold Bros. & Driller: 0-106 ft quicksand \\
\hline $\mathrm{Cb}-68$ & 112GLCD & GRVL & 98 & 20 & $00-00-30$ & $\mathrm{R}$ & 25 & Shaver, Wm. & Well taps gravel overlying rock \\
\hline $\mathrm{Cb}-69$ & 112GLCD & GRVL & 66 & 15 & $00-00-43$ & $\mathrm{R}$ & 25 & Shaver, Wm & Well taps coarse gravel over rock \\
\hline $\mathrm{Cb}-70$ & 112GLCD & GRVL & 83 & 20 & $00-00-45$ & $\mathrm{R}$ & 20 & Shaver, Wm. & Well taps gravel just above rock \\
\hline $\mathrm{Cb}-71$ & 112OTSH & SDGL & 0 & 6 & 00-00-39 & $\mathrm{R}$ & -- & -- & Originally inventoried for county GW study \\
\hline $\mathrm{Cb}-72$ & 112GLCD & SDGL & 120 & 63 & $00-00-41$ & $\mathrm{R}$ & 2.5 & Grmntn Artsn & Reported avg WL \\
\hline $\mathrm{Cb}-73$ & $377 \mathrm{NSSU}$ & SHLE & 15 & 15 & $00-00-35$ & $\mathrm{R}$ & 1.0 & Shaver, Wm. & Well installed in existing dug well rock at $15 \mathrm{ft}$. \\
\hline $\mathrm{Cb}-74$ & 371TCSQ & SHLE & 26 & 26 & $00-00-20$ & $\mathrm{R}$ & 1.0 & Grmntn Artsn & -- \\
\hline $\mathrm{Cb}-75$ & 112GLCD & GRVL & -- & 20 & $00-00-20$ & $\mathrm{R}$ & 10 & Shaver, Wm. & Supplies three households \\
\hline $\mathrm{Cb}-76$ & 377SCCK & SHLE & 91 & 13 & $04-00-45$ & $\mathrm{R}$ & 5 & Shaver, Wm. & Originally inventoried for county GW study \\
\hline $\mathrm{Cb}-77$ & 112OTSH & SDGL & 0 & 18 & 00-00-38 & $\mathrm{R}$ & 25 & Shaver, Wm. & 6-inch drilled bedrock well nearby \\
\hline $\mathrm{Cb}-78$ & $377 \mathrm{NSSU}$ & SHLE & 123 & 55 & $04-00-43$ & $\mathrm{R}$ & 7 & Goold Bros. & Reported avg WL \\
\hline Cb-79 & 371TCSQ & SHLE & 75 & 32 & $00-00-22$ & $\mathrm{R}$ & .7 & Grmntn Artsn & Reported avg WL, H2S reported \\
\hline $\mathrm{Cb}-80$ & 377SCCK & SLTE & 6 & 17 & 09-00-30 & $\mathrm{R}$ & 6 & Goold Bros & Average water use $700 \mathrm{gpd}$ \\
\hline $\mathrm{Cb}-81$ & 377SCCK & SHLE & 65 & 40 & $00-00-41$ & $\mathrm{R}$ & 1 & Grmntn Artsn & Originally inventoried for county GW study \\
\hline $\mathrm{Cb}-82$ & 377SCCK & SHLE & 7 & 10 & $00-00-31$ & $\mathrm{R}$ & 6 & Grmntn Artsn & Moderately hard water reported \\
\hline
\end{tabular}


¿ Appendix 1. Records of wells in the Schodack-Kinderhook area, Rensselaer and Columbia Counties, N.Y.

B. Wells south of $42^{\circ} 30^{\prime}$.

\begin{tabular}{|c|c|c|c|c|c|c|c|c|c|c|c|c|c|c|}
\hline $\begin{array}{l}\text { Local } \\
\text { well } \\
\text { number }\end{array}$ & Site ID & $\begin{array}{l}\text { Latitude } \\
\text { (degrees) }\end{array}$ & $\begin{array}{l}\text { Longitude } \\
\text { (degrees) }\end{array}$ & Owner & $\begin{array}{c}\text { Altitude } \\
\text { of land } \\
\text { surface } \\
\text { (feet) }\end{array}$ & $\begin{array}{c}\text { Primary } \\
\text { use of } \\
\text { water }\end{array}$ & $\begin{array}{l}\text { Local } \\
\text { well } \\
\text { number }\end{array}$ & $\begin{array}{c}\text { Date of } \\
\text { con- } \\
\text { struction }\end{array}$ & $\begin{array}{l}\text { Method } \\
\text { con- } \\
\text { structed }\end{array}$ & $\begin{array}{c}\text { Diameter } \\
\text { of casing } \\
\text { (in) }\end{array}$ & $\begin{array}{c}\text { Depth of } \\
\text { well } \\
\text { (feet) }\end{array}$ & $\begin{array}{c}\text { Source } \\
\text { of } \\
\text { depth } \\
\text { data }\end{array}$ & $\begin{array}{l}\text { Bottom } \\
\text { of } \\
\text { casing } \\
\text { (feet) }\end{array}$ & $\begin{array}{c}\text { Type of } \\
\text { finish }\end{array}$ \\
\hline $\mathrm{Cb}-83$ & 422615073450801 & 422611 & 0734507 & Crouthamel, W.K. & 230 & $\mathrm{H}$ & 83 & $00-00-25$ & $\mathrm{C}$ & 6 & 127 & $\mathrm{D}$ & 23.5 & $\mathrm{X}$ \\
\hline $\mathrm{Cb}-84$ & 422355073432701 & 422350 & 0734326 & Ogden, Alfred & 250 & $\mathrm{H}$ & 84 & 00-00-11 & $\mathrm{C}$ & 6 & 124 & $\mathrm{D}$ & 40 & $\mathrm{X}$ \\
\hline $\mathrm{Cb}-85$ & 422255073432201 & 422254 & 0734323 & Smith, Dr. Dwight & 230 & $\mathrm{H}$ & 85 & 00-00-46 & $\mathrm{C}$ & 6 & 295 & $\mathrm{D}$ & 92 & $\mathrm{X}$ \\
\hline $\mathrm{Cb}-86$ & 422343073424201 & 422339 & 0734241 & Kinderhook Fruit Co. & 255 & $\mathrm{U}$ & 86 & $07-00-23$ & $\mathrm{C}$ & 8 & 196 & $\mathrm{D}$ & 120 & $\mathrm{X}$ \\
\hline $\mathrm{Cb}-87$ & 422356073422701 & 422354 & 0734223 & Echo Fruit Farm & 265 & $\mathrm{C}$ & 87 & $00-00-95$ & $\mathrm{C}$ & 6 & 87 & $\mathrm{O}$ & 80 & $\mathrm{X}$ \\
\hline $\mathrm{Cb}-88$ & 422423073424801 & 422423 & 0734248 & Howard, Lawrence & 265 & $\mathrm{H}$ & 88 & $00-00-13$ & $\mathrm{C}$ & 6 & 165 & $\mathrm{O}$ & 165 & $\mathrm{O}$ \\
\hline $\mathrm{Cb}-89$ & 422429073423401 & 422427 & 0734235 & Dorman, E.O. & 270 & $\mathrm{H}$ & 89 & $12-00-44$ & $\mathrm{C}$ & 6 & 119 & $\mathrm{D}$ & 37 & $\mathrm{X}$ \\
\hline $\mathrm{Cb}-90$ & 422452073421301 & 422450 & 0734215 & Mcvaugh, Roy & 280 & $S$ & 90 & $00-00-30$ & $\mathrm{C}$ & 6 & 193 & $\mathrm{D}$ & 108 & $\mathrm{X}$ \\
\hline Cb-91 & 422328073413301 & 422328 & 0734133 & Village of Kinderhook & 200 & $\mathrm{P}$ & 91 & $00-00-38$ & $\mathrm{C}$ & 8 & 31 & $\mathrm{D}$ & 26 & $S$ \\
\hline Cb-92 & 422327073413401 & 422327 & 0734134 & Inc. Village of Kinderhook & 200 & $\mathrm{P}$ & 92 & $00-00-22$ & $\mathrm{C}$ & 4.5 & 24 & $\mathrm{D}$ & 24 & $\mathrm{O}$ \\
\hline $\mathrm{Cb}-93$ & 422327073413301 & 422327 & 0734133 & Inc. Village of Kinderhook & 200 & $\mathrm{P}$ & 93 & $00-00-22$ & $\mathrm{C}$ & 4.5 & 24 & $\mathrm{D}$ & 24 & $\mathrm{O}$ \\
\hline Cb-94 & 422329073413301 & 422329 & 0734133 & Inc. Village of Kinderhook & 200 & $\mathrm{P}$ & 94 & $00-00-22$ & $\mathrm{C}$ & 4.5 & 24 & $\mathrm{D}$ & 24 & $\mathrm{O}$ \\
\hline $\mathrm{Cb}-95$ & 422326073413901 & 422326 & 0734139 & Davie, George H. & 200 & $\mathrm{H}$ & 95 & $00-00-22$ & $\mathrm{C}$ & 6 & 21 & $\mathrm{D}$ & 21 & S \\
\hline Cb-96 & 422536073425001 & 422536 & 0734250 & Van Alstyne, Louis & 240 & $\mathrm{H}$ & 96 & -- & $\mathrm{C}$ & 4 & 80 & $\mathrm{D}$ & 80 & $\mathrm{O}$ \\
\hline Cb-98 & 422325073411301 & 422321 & 0734110 & Hand, J.C. & 270 & $\mathrm{H}$ & 98 & 00-00-29 & $\mathrm{C}$ & 6 & 155 & $\mathrm{D}$ & 12 & $\mathrm{X}$ \\
\hline Cb-99 & 422330073405901 & 422330 & 0734059 & Commancher, Wm. & 320 & $\mathrm{H}$ & 99 & 00-00-30 & $\mathrm{C}$ & 6 & 84 & $\mathrm{D}$ & 3 & $\mathrm{X}$ \\
\hline $\mathrm{Cb}-102$ & 422447073394401 & 422443 & 0733945 & Garrigan, Walter & 280 & $\mathrm{H}$ & 102 & 00-00-38 & $\mathrm{C}$ & 4 & 108 & $\mathrm{D}$ & 15 & $\mathrm{X}$ \\
\hline $\mathrm{Cb}-103$ & 422355073393301 & 422355 & 0733933 & Ibert, M. & 310 & $\mathrm{H}$ & 103 & $00-00-36$ & $\mathrm{C}$ & 6 & 50 & $\mathrm{O}$ & 30 & $\mathrm{X}$ \\
\hline $\mathrm{Cb}-104$ & 422333073393301 & 422330 & 0733933 & Mc Cagg, Dick & 300 & $\mathrm{H}$ & 104 & $11-00-43$ & $\mathrm{C}$ & 6 & 80 & $\mathrm{D}$ & 14 & $\mathrm{X}$ \\
\hline $\mathrm{Cb}-105$ & 422346073384901 & 422343 & 0733841 & Crandall, W.S. & 310 & $\mathrm{H}$ & 105 & $00-00-14$ & $\mathrm{C}$ & 6 & 280 & $\mathrm{D}$ & 25 & $\mathrm{X}$ \\
\hline $\mathrm{Cb}-127$ & 422305073383401 & 422302 & 0733831 & Mc Clellan, Hugh & 340 & $\mathrm{H}$ & 127 & $05-00-35$ & $\mathrm{C}$ & 6 & 71 & $\mathrm{D}$ & 12 & $\mathrm{X}$ \\
\hline $\mathrm{Cb}-128$ & 422243073382301 & 422243 & 0733823 & Mason, Richard & 350 & $\mathrm{H}$ & 128 & $00-00-24$ & $\mathrm{C}$ & 6 & 92 & $\mathrm{D}$ & 39 & $\mathrm{X}$ \\
\hline $\mathrm{Cb}-130$ & 422243073403401 & 422241 & 0734034 & Benhofft, Fred & 450 & $\mathrm{H}$ & 130 & $00-00-25$ & $\mathrm{C}$ & 6 & 90 & $\mathrm{D}$ & 26 & $\mathrm{X}$ \\
\hline
\end{tabular}


Appendix 1. Records of wells in the Schodack-Kinderhook area, Rensselaer and Columbia Counties, N.Y. B. Wells south of $42^{\circ} 30^{\prime}$.

\begin{tabular}{|c|c|c|c|c|c|c|c|c|c|}
\hline $\begin{array}{l}\text { Local } \\
\text { well } \\
\text { number }\end{array}$ & Aquifer code & $\begin{array}{l}\text { Lithology } \\
\text { code }\end{array}$ & $\begin{array}{l}\text { Depth } \\
\text { to top } \\
\text { (feet) }\end{array}$ & $\begin{array}{l}\text { Water } \\
\text { level } \\
\text { (feet) }\end{array}$ & $\begin{array}{c}\text { Date } \\
\text { water } \\
\text { level } \\
\text { measured }\end{array}$ & $\begin{array}{l}\text { Method } \\
\text { water } \\
\text { level } \\
\text { measured }\end{array}$ & $\begin{array}{l}\text { Discharge } \\
\quad(\mathrm{gpm})\end{array}$ & Contractor & Remarks \\
\hline $\mathrm{Cb}-83$ & $377 \mathrm{SCCK}$ & LMSN & 23.5 & 27 & $00-00-25$ & $\mathrm{R}$ & 1 & Grmntn Artsn & Owner reports hard water \\
\hline $\mathrm{Cb}-84$ & $377 N S S U$ & SHLE & 40 & 36 & 00-00-11 & $\mathrm{R}$ & 16 & Grmntn Artsn & Some hardness reported \\
\hline $\mathrm{Cb}-85$ & $377 N S S U$ & SHLE & 92 & 27 & $00-00-46$ & $\mathrm{R}$ & 5 & Gordon Goold & Original $160 \mathrm{ft}$ well deepened to $295 \mathrm{ft} 1946$ \\
\hline $\mathrm{Cb}-86$ & 371TCSQ & SHLE & 120 & 125 & $07-00-23$ & $\mathrm{R}$ & 10 & Grmntn Artsn & Well not used, yield inadequate \\
\hline $\mathrm{Cb}-87$ & 371TCSQ & SLTE & 80 & 38 & 00-00-95 & $\mathrm{R}$ & 30 & Grmntn Artsn & Soft water reported, water for cold storage \\
\hline $\mathrm{Cb}-88$ & 112GLCD & GRVL & 165 & 20 & $10-12-45$ & $\mathrm{R}$ & 4.5 & Grmntn Artsn & Some question as to veracity of $\log$ \\
\hline $\mathrm{Cb}-89$ & 371TCSQ & SLTE & 37 & 21 & $12-00-44$ & $\mathrm{R}$ & 15 & Goold Bros & Very soft water reported \\
\hline $\mathrm{Cb}-90$ & 371TCSQ & SHLE & 108 & 85 & $00-00-30$ & $\mathrm{R}$ & 3 & Grmntn Artsn & Water used primarily for fruit tree spraying \\
\hline $\mathrm{Cb}-91$ & 111ALVM & GRVL & 0 & 12 & $00-00-38$ & $\mathrm{R}$ & 150 & Shaver, Wm & QW analysis and well data in Bull. GW-25 \\
\hline $\mathrm{Cb}-92$ & 111ALVM & GRVL & 0 & 10 & $00-00-22$ & $\mathrm{R}$ & 50 & Grmntn Artsn & One of 3 standby wells on common suction \\
\hline $\mathrm{Cb}-93$ & 111ALVM & GRVL & 0 & 10 & $00-00-22$ & $\mathrm{R}$ & 50 & Grmntn Artsn & One of 3 standby wells on common suction \\
\hline Cb-94 & 111ALVM & GRVL & 0 & 10 & $00-00-22$ & $\mathrm{R}$ & 50 & Grmntn Artsn & One of 3 Standby Wells on common suction \\
\hline $\mathrm{Cb}-95$ & 111ALVM & GRVL & 0 & 9 & $00-00-22$ & $\mathrm{R}$ & 5 & Grmntn Artsn & Originally inventoried for county GW study \\
\hline $\mathrm{Cb}-96$ & $112 \mathrm{GLCD}$ & GRVL & 78 & 3 & $11-15-45$ & $\mathrm{R}$ & 3 & Shaver, Wm & Well drilled in dug well, taps grvl, brkn rx \\
\hline $\mathrm{Cb}-98$ & 377NSSU & SHLE & 12 & 12 & 00-00-29 & $\mathrm{R}$ & 3 & Grmntn Artsn & Moderately hard water reported \\
\hline $\mathrm{Cb}-99$ & $377 \mathrm{NSSU}$ & SHLE & 0 & 12 & $00-00-30$ & $\mathrm{R}$ & 2.5 & Grmntn Artsn & Originally inventoried for county GW study \\
\hline $\mathrm{Cb}-102$ & $377 \mathrm{NSSU}$ & SHLE & 15 & 25 & $00-00-38$ & $\mathrm{R}$ & 4 & Shaver, Wm & Hard water reported \\
\hline $\mathrm{Cb}-103$ & $377 \mathrm{NSSU}$ & SHLE & 30 & 12 & $00-00-36$ & $\mathrm{R}$ & -- & -- & Originally inventoried for county GWsStudy \\
\hline $\mathrm{Cb}-104$ & 371TCSQ & SHLE & 14 & 12 & $11-00-43$ & $\mathrm{R}$ & 6 & Goold Bros & Soft water reported \\
\hline $\mathrm{Cb}-105$ & 371TCSQ & SHLE & 25 & -- & -- & - & 9 & Grmntn Artsn & QW analysis in table 4, Bulletin GW-25 \\
\hline $\mathrm{Cb}-127$ & 371TCSQ & SLTE & 12 & 19 & $05-00-35$ & $\mathrm{R}$ & 10 & Goold Bros & Mt. Merino Fm. \\
\hline $\mathrm{Cb}-128$ & 371TCSQ & SHLE & 39 & 17 & $00-00-24$ & $\mathrm{R}$ & 2 & Grmntn Artsn & Probably drilled in Germantown Fm. \\
\hline $\mathrm{Cb}-130$ & $377 N S S U$ & SHLE & 20 & 20 & $00-00-25$ & $\mathrm{R}$ & 1.25 & Grmntn Artsn & Originally inventoried for county GW study \\
\hline
\end{tabular}


Appendix 1. Records of wells in the Schodack-Kinderhook area, Rensselaer and Columbia Counties, N.Y.

B. Wells south of $42^{\circ} 30^{\prime}$.

\begin{tabular}{|c|c|c|c|c|c|c|c|c|c|c|c|c|c|c|}
\hline $\begin{array}{l}\text { Local } \\
\text { well } \\
\text { number }\end{array}$ & Site ID & $\begin{array}{l}\text { Latitude } \\
\text { (degrees) }\end{array}$ & $\begin{array}{l}\text { Longitude } \\
\text { (degrees) }\end{array}$ & Owner & $\begin{array}{c}\text { Altitude } \\
\text { of land } \\
\text { surface } \\
\text { (feet) }\end{array}$ & $\begin{array}{c}\text { Primary } \\
\text { use of } \\
\text { water }\end{array}$ & $\begin{array}{l}\text { Local } \\
\text { well } \\
\text { number }\end{array}$ & $\begin{array}{l}\text { Date of } \\
\text { con- } \\
\text { struction }\end{array}$ & $\begin{array}{l}\text { Method } \\
\text { con- } \\
\text { structed }\end{array}$ & $\begin{array}{c}\text { Diameter } \\
\text { of casing } \\
\text { (in) }\end{array}$ & $\begin{array}{l}\text { Depth of } \\
\text { well } \\
\text { (feet) }\end{array}$ & $\begin{array}{c}\text { Source } \\
\text { of } \\
\text { depth } \\
\text { data }\end{array}$ & $\begin{array}{l}\text { Bottom } \\
\text { of } \\
\text { casing } \\
\text { (feet) }\end{array}$ & $\begin{array}{c}\text { Type of } \\
\text { finish }\end{array}$ \\
\hline $\mathrm{Cb}-131$ & 422243073412601 & 422243 & 0734126 & Ichabod Crane School (District 6) & 240 & $\mathrm{~T}$ & 131 & $00-00-38$ & $\mathrm{C}$ & 6 & 98 & $\mathrm{D}$ & 71 & $\mathrm{X}$ \\
\hline $\mathrm{Cb}-132$ & 422241073412801 & 422239 & 0734128 & Ichabod Crane School (Carl Fisher) & 250 & $\mathrm{H}$ & 132 & $00-00-42$ & $\mathrm{C}$ & 6 & 100 & $\mathrm{D}$ & 75 & $\mathrm{X}$ \\
\hline $\mathrm{Cb}-143$ & 422233073452401 & 422233 & 0734524 & Best, Mary K. & 110 & $\mathrm{H}$ & 143 & $00-00-17$ & $\mathrm{C}$ & 6 & 281 & $\mathrm{D}$ & 159 & $\mathrm{X}$ \\
\hline $\mathrm{Cb}-144$ & 422320073461501 & 422320 & 0734615 & Mitchell, John G. & 160 & $\mathrm{H}$ & 144 & -- & $\mathrm{C}$ & 6 & 138 & $\mathrm{D}$ & 122 & $\mathrm{X}$ \\
\hline $\mathrm{Cb}-145$ & 422327073463601 & 422327 & 0734636 & Stuyvesant School & 130 & $\mathrm{~T}$ & 145 & $00-00-26$ & $\mathrm{C}$ & 6 & 120 & $\mathrm{D}$ & 95 & $\mathrm{X}$ \\
\hline $\mathrm{Cb}-146$ & 422337073464901 & 422333 & 0734647 & Odd Fellows Home & 120 & $\mathrm{~T}$ & 146 & $12-00-27$ & $\mathrm{C}$ & 8 & 475 & $\mathrm{D}$ & 100 & $\mathrm{X}$ \\
\hline $\mathrm{Cb}-147$ & 422323073464701 & 422323 & 0734653 & Van Alstyne, Wm. & 110 & $\mathrm{H}$ & 147 & $11-00-31$ & $\mathrm{C}$ & 6 & 134 & $\mathrm{D}$ & 134 & $\mathrm{O}$ \\
\hline $\mathrm{Cb}-148$ & 422321073464601 & 422321 & 0734646 & Paul, Thomas & 130 & $\mathrm{H}$ & 148 & $07-00-33$ & $\mathrm{C}$ & 6 & 140 & $\mathrm{D}$ & 140 & $\mathrm{O}$ \\
\hline $\mathrm{Cb}-149$ & 422314073470001 & 422314 & 0734700 & Edwards, James & 100 & $\mathrm{H}$ & 149 & $00-00-28$ & $\mathrm{C}$ & 6 & 100 & $\mathrm{D}$ & 14 & $\mathrm{X}$ \\
\hline $\mathrm{Cb}-150$ & 422309073470301 & 422309 & 0734700 & Stuyvesant Catholic Church & 110 & $\mathrm{~T}$ & 150 & $00-00-22$ & $\mathrm{C}$ & 6 & 165 & $\mathrm{D}$ & 165 & $\mathrm{O}$ \\
\hline $\mathrm{Cb}-151$ & 422245073464301 & 422245 & 0734643 & McElheny, Victor & 170 & $\mathrm{H}$ & 151 & $00-00-14$ & $\mathrm{C}$ & 8 & 502 & $\mathrm{D}$ & 95 & $\mathrm{X}$ \\
\hline $\mathrm{Cb}-152$ & 422245073470101 & 422244 & 0734700 & McElheny, V.K. & 30 & $\mathrm{H}$ & 152 & $00-00-26$ & $\mathrm{C}$ & 6 & 240 & $\mathrm{D}$ & 74 & $\mathrm{X}$ \\
\hline $\mathrm{Cb}-157$ & 422315073452801 & 422315 & 0734532 & Thomas, Ralph & 120 & $\mathrm{H}$ & 157 & $03-00-44$ & $\mathrm{C}$ & 4 & 319 & $\mathrm{D}$ & 275 & $\mathrm{X}$ \\
\hline $\mathrm{Cb}-161$ & 422314073433701 & 422314 & 0734337 & Smith, Elliot & 260 & $\mathrm{H}$ & 161 & $00-00-46$ & $\mathrm{C}$ & -- & 315 & $\mathrm{D}$ & 102 & $\mathrm{X}$ \\
\hline $\mathrm{Cb}-162$ & 422324073461201 & 422322 & 0734611 & Calkins, Arthur & 160 & $\mathrm{H}$ & 162 & $00-00-32$ & $\mathrm{C}$ & 6 & 160 & $\mathrm{D}$ & 118 & $\mathrm{X}$ \\
\hline Cb-163 & 422322073460401 & 422322 & 0734604 & Losee, S. & 160 & $\mathrm{H}$ & 163 & $00-00-36$ & $\mathrm{C}$ & 6 & 141 & $\mathrm{D}$ & 76 & $\mathrm{X}$ \\
\hline $\mathrm{Cb}-164$ & 422737073461501 & 422730 & 0734616 & Vaneyk, John & 80 & $\mathrm{H}$ & 164 & $00-00-10$ & $\mathrm{C}$ & 6 & 132 & $\mathrm{D}$ & 48 & $\mathrm{X}$ \\
\hline Cb-193 & 422806073383301 & 422806 & 0733833 & Van Der Goes, Phillip & 340 & $\mathrm{H}$ & 193 & -- & V & -- & 22 & $\mathrm{O}$ & 22 & $\mathrm{~T}$ \\
\hline Cb-198 & 422355073382801 & 422353 & 0733824 & Sommers, Kate & 260 & $\mathrm{H}$ & 198 & $00-00-27$ & $\mathrm{C}$ & 6 & 80 & $\mathrm{D}$ & 71 & $\mathrm{X}$ \\
\hline $\mathrm{Cb}-199$ & 422352073381901 & 422351 & 0733821 & Sommers, Frank Jr. & 270 & $\mathrm{H}$ & 199 & $00-00-27$ & $\mathrm{C}$ & 6 & 80 & $\mathrm{D}$ & 71 & $\mathrm{X}$ \\
\hline $\mathrm{Cb}-855$ & 422335073413501 & 422328 & 0734132 & Village of Kinderhook & 200 & $\mathrm{P}$ & 855 & $10-00-47$ & $\mathrm{C}$ & 6 & 35 & $\mathrm{D}$ & 29 & $S$ \\
\hline $\mathrm{Cb}-856$ & 422335073413502 & 422328 & 0734132 & Village of Kinderhook & 200 & $\mathrm{P}$ & 856 & $10-00-47$ & $\mathrm{C}$ & 8 & 34 & $\mathrm{D}$ & 28 & G \\
\hline $\mathrm{Cb}-862$ & 422436073411701 & 422430 & 0734118 & Inc. Village of Valatie & 210 & $\mathrm{P}$ & 862 & -- & $\mathrm{C}$ & 8 & 52 & $\mathrm{D}$ & 47 & $S$ \\
\hline
\end{tabular}


Appendix 1. Records of wells in the Schodack-Kinderhook area, Rensselaer and Columbia Counties, N.Y. B. Wells south of $42^{\circ} 30^{\prime}$.

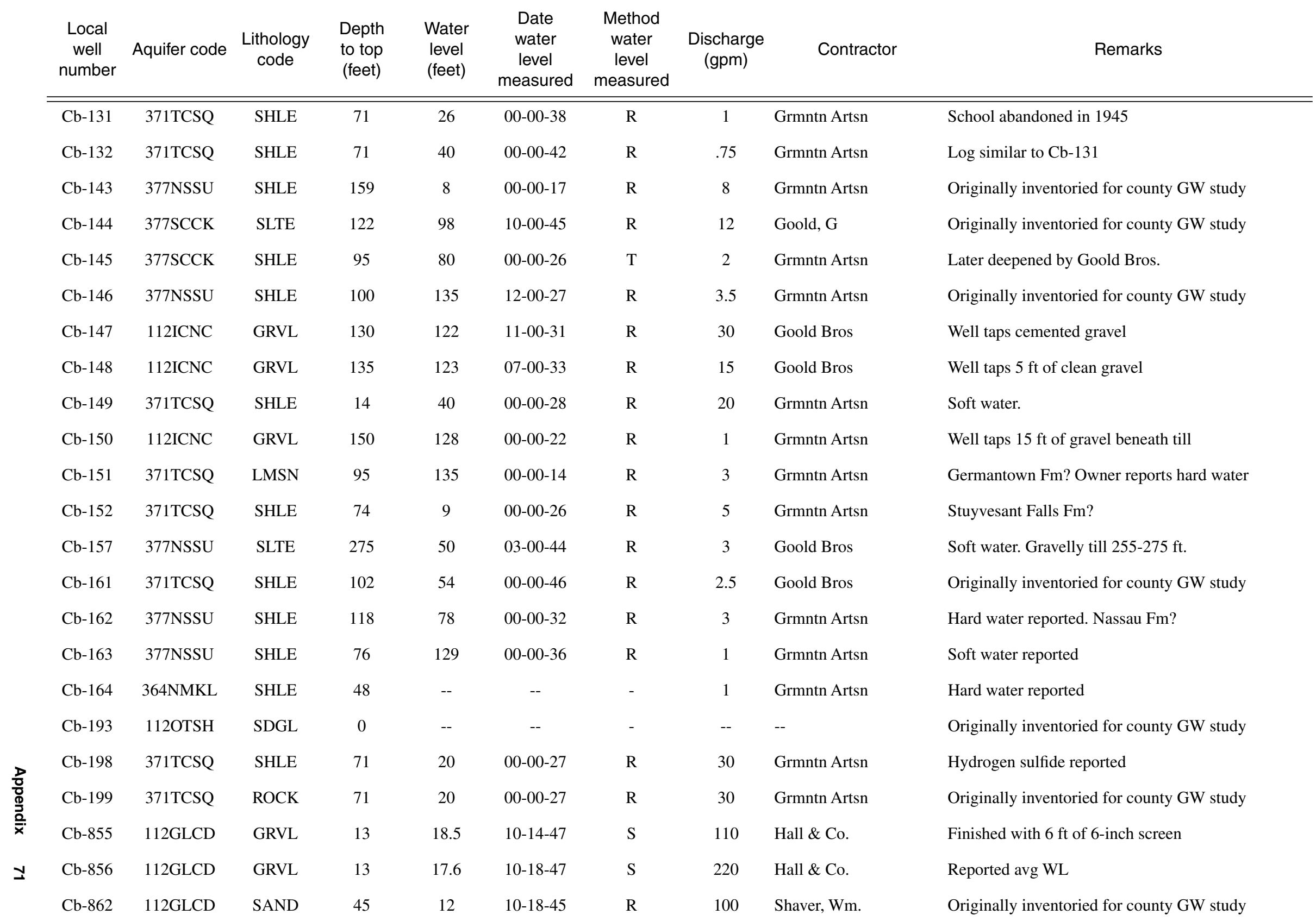


N Appendix 1. Records of wells in the Schodack-Kinderhook area, Rensselaer and Columbia Counties, N.Y.

B. Wells south of $42^{\circ} 30^{\prime}$.

\begin{tabular}{|c|c|c|c|c|c|c|c|c|c|c|c|c|c|c|}
\hline $\begin{array}{l}\text { Local } \\
\text { well } \\
\text { number }\end{array}$ & Site ID & $\begin{array}{l}\text { Latitude } \\
\text { (degrees) }\end{array}$ & $\begin{array}{r}\text { Longitude } \\
\text { (degrees) }\end{array}$ & Owner & $\begin{array}{l}\text { Altitude } \\
\text { of land } \\
\text { surface } \\
\text { (feet) }\end{array}$ & $\begin{array}{c}\text { Primary } \\
\text { use of } \\
\text { water }\end{array}$ & $\begin{array}{l}\text { Local } \\
\text { well } \\
\text { number }\end{array}$ & $\begin{array}{l}\text { Date of } \\
\text { con- } \\
\text { struction }\end{array}$ & $\begin{array}{l}\text { Method } \\
\text { con- } \\
\text { structed }\end{array}$ & $\begin{array}{l}\text { Diameter } \\
\text { of casing } \\
\text { (in) }\end{array}$ & $\begin{array}{l}\text { Depth of } \\
\text { well } \\
\text { (feet) }\end{array}$ & $\begin{array}{c}\text { Source } \\
\text { of } \\
\text { depth } \\
\text { data }\end{array}$ & $\begin{array}{l}\text { Bottom } \\
\text { of } \\
\text { casing } \\
\text { (feet) }\end{array}$ & $\begin{array}{c}\text { Type of } \\
\text { finish }\end{array}$ \\
\hline 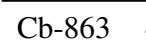 & 422429073411101 & 422429 & 0734111 & Inc. Village of Valatie & 210 & $\mathrm{P}$ & 863 & -- & $\mathrm{D}$ & 36 & 21 & G & 21 & $\mathrm{~W}$ \\
\hline $\mathrm{Cb}-864$ & 422429073411201 & 422429 & 0734112 & Inc. Village of Valatie & 210 & $\mathrm{P}$ & 864 & -- & $\mathrm{D}$ & 36 & 10 & G & 10 & W \\
\hline $\mathrm{Cb}-865$ & 422436073411702 & 422429 & 0734114 & Inc. Village of Valatie & 210 & $\mathrm{P}$ & 865 & -- & $\mathrm{D}$ & 30 & 15.5 & G & 15.5 & $\mathrm{H}$ \\
\hline $\mathrm{Cb}-866$ & 422429073411601 & 422429 & 0734116 & Inc. Village of Valatie & 210 & $\mathrm{P}$ & 866 & -- & $\mathrm{D}$ & 36 & 13.5 & G & 13.5 & $\mathrm{~W}$ \\
\hline $\mathrm{Cb}-867$ & 422429073411701 & 422429 & 0734117 & Inc. Village of Valatie & 210 & $\mathrm{P}$ & 867 & -- & $\mathrm{D}$ & 36 & 13.5 & G & 13.5 & $\mathrm{~W}$ \\
\hline $\mathrm{Cb}-869$ & 422436073411703 & 422429 & 0734120 & Inc. Village of Valatie & 210 & $\mathrm{P}$ & 869 & -- & $\mathrm{C}$ & 8 & 50 & $\mathrm{D}$ & 45 & S \\
\hline $\mathrm{Cb}-870$ & 422436073411704 & 422429 & 0734118 & Inc.. Village of Valatie & 210 & $\mathrm{P}$ & 870 & -- & $\mathrm{C}$ & 8 & 35 & $\mathrm{D}$ & 30 & $S$ \\
\hline Cb-986 & 422307073452301 & 422307 & 0734523 & Webber, E. & 120 & $\mathrm{H}$ & 986 & $00-00-17$ & $\mathrm{C}$ & 6 & 271 & $\mathrm{O}$ & 174 & $\mathrm{X}$ \\
\hline Cb-994 & 422251073443101 & 422251 & 0734431 & West, C. Jr. & 190 & $\mathrm{H}$ & 994 & -- & $\mathrm{C}$ & 6 & 74 & $\mathrm{O}$ & 28 & $\mathrm{X}$ \\
\hline Cb-995 & 422241073434701 & 422241 & 0734347 & Van Alstyne, W.B. & 220 & $\mathrm{H}$ & 995 & 00-00-00 & $\mathrm{C}$ & 6 & 156 & $\mathrm{O}$ & 85 & $\mathrm{X}$ \\
\hline $\mathrm{Cb}-1036$ & 422600073404301 & 422600 & 0734043 & Valatie Research Farm & 310 & $\mathrm{U}$ & 1036 & 06-18-94 & A & 6 & 67.5 & $S$ & 64.0 & $\mathrm{X}$ \\
\hline $\mathrm{Cb}-1040$ & 422328073413304 & 422328 & 0734133 & Village of Kinderhook & 200 & $\mathrm{P}$ & 1040 & 00-00-66 & $\mathrm{C}$ & 12 & 36 & G & 27 & S \\
\hline Cb-1048 & 422602073413701 & 422602 & 0734137 & Jeff Pinkowski (Builder) & 303 & $\mathrm{H}$ & 1048 & $10-00-90$ & -- & 6 & -- & $S$ & -- & -- \\
\hline Cb-1049 & 422527073420501 & 422527 & 0734205 & Devine, Mrs. Barbara & 295 & $\mathrm{U}$ & 1049 & $11-09-88$ & $\mathrm{C}$ & 6 & 138.5 & $\mathrm{D}$ & 135.5 & $S$ \\
\hline $\mathrm{Cb}-1050$ & 422527073420502 & 422527 & 0734205 & Devine, Mrs. Barbara & 296 & $\mathrm{U}$ & 1050 & $06-25-88$ & A & 6 & 540 & $\mathrm{D}$ & 136 & $\mathrm{X}$ \\
\hline Cb-1051 & 422524073405501 & 422524 & 0734055 & Austin, Sam & 320 & $\mathrm{H}$ & 1051 & $07-08-92$ & - & 6 & 180 & $\mathrm{O}$ & -- & $\mathrm{X}$ \\
\hline Cb-1052 & 422427073410001 & 422430 & 0734108 & Inc. Village of Valatie & 207 & $\mathrm{P}$ & 1052 & 08-00-61 & - & 10 & 33 & G & 26 & G \\
\hline $\mathrm{Cb}-1054$ & 422545073410701 & 422545 & 0734107 & Kleeber Realty Inc. & 300 & $\mathrm{U}$ & 1054 & 08-00-89 & $\mathrm{C}$ & 6 & 353 & $\mathrm{D}$ & 41 & $\mathrm{X}$ \\
\hline Cb-1056 & 422606073415101 & 422606 & 0734151 & Associated Fruit Growers & 302 & $\mathrm{H}$ & 1056 & -- & - & 6 & -- & - & -- & - \\
\hline Cb-1057 & 422526073405201 & 422526 & 0734052 & Austin, Wayne & 308 & $\mathrm{H}$ & 1057 & $10-11-93$ & $\mathrm{C}$ & 6 & 240 & $\mathrm{O}$ & -- & $\mathrm{X}$ \\
\hline $\mathrm{Cb}-1058$ & 422536073411601 & 422536 & 0734116 & Hudson City Savings Institution & 301 & $\mathrm{U}$ & 1058 & -- & $\mathrm{C}$ & 6 & -- & - & -- & $\mathrm{X}$ \\
\hline Cb-1059 & 422541073411101 & 422541 & 0734111 & Hudson City Savings Institution & 302 & $\mathrm{U}$ & 1059 & -- & $\mathrm{C}$ & 6 & 179 & S & 174 & $\mathrm{X}$ \\
\hline 1060 & 422537073411601 & 422537 & 0734116 & Hudson City Savings Institution & 304 & $\mathrm{H}$ & 1060 & $-27-93$ & - & 6 & 173 & $\mathrm{O}$ & -- & $\mathrm{X}$ \\
\hline
\end{tabular}


Appendix 1. Records of wells in the Schodack-Kinderhook area, Rensselaer and Columbia Counties, N.Y. B. Wells south of $42^{\circ} 30^{\prime}$.

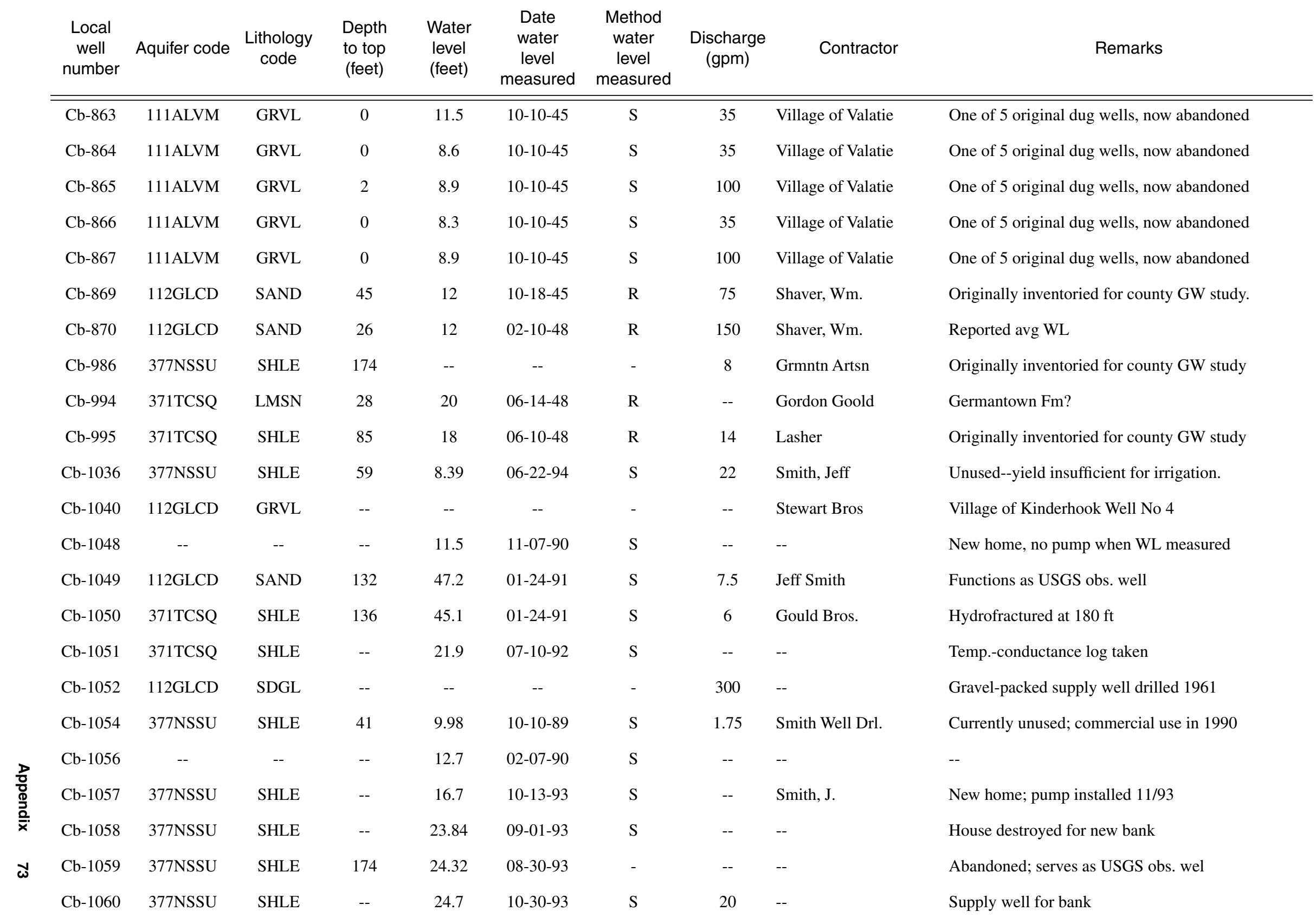

